\author{
UNIVERSIDADE DE SÃO PAULO \\ INSTITUTO DE ENERGIA E AMBIENTE \\ PROGRAMA DE PÓS-GRADUAÇÃO EM CIÊNCIA AMBIENTAL
}

BRUNO RANIELY GONÇALVES SANTOS

ANÁLISE DOS CRITÉRIOS ADOTADOS E DOS EMPREENDIMENTOS FINANCIADOS COM RECURSOS

DO FEHIDRO NA BACIA DO SOROCABA E MÉDIO TIETÊ 


\section{ANÁLISE DOS CRITÉRIOS ADOTADOS E DOS EMPREENDIMENTOS FINANCIADOS COM RECURSOS DO FEHIDRO NA BACIA DO SOROCABA E MÉDIO TIETÊ}

Dissertação apresentada ao Programa de PósGraduação em Ciência Ambiental do Instituto de Energia e Ambiente da Universidade de São Paulo para a obtenção do título de Mestre em Ciência Ambiental.

Orientador: Prof. ${ }^{a}$ Dr. ${ }^{a}$ Ana Paula Fracalanza

Versão Corrigida

(versão original disponível na Biblioteca do Instituto de Energia e Ambiente e na Biblioteca Digital de Teses e Dissertações da USP)

\section{SÃO PAULO}

2018 
AUTORIZO A REPRODUÇÃO E DIVULGAÇÃO TOTAL OU PARCIAL DESTE TRABALHO, POR QUALQUER MEIO CONVENCIONAL OU ELETRÔNICO, PARA FINS DE ESTUDO E PESQUISA, DESDE QUE CITADA A FONTE.

FICHA CATALOGRÁFICA

Santos, Bruno Raniely Gonçalves.

Análise dos critérios adotados e dos empreendimentos financiados com recursos do FEHIDRO na bacia do Sorocaba e médio Tietê. / Bruno Raniely Gonçalves Santos; orientador: Ana Paula Fracalanza. -- São Paulo, 2018.

$156 \mathrm{f}:$ il; $30 \mathrm{~cm}$

Dissertação (Mestrado em Ciência Ambiental) - Programa de PósGraduação em Ciência Ambiental - Instituto de Energia e Ambiente da Universidade de São Paulo.

1. Recursos hídricos - aspectos político-socioeconômico. 2 . Bacia hidrográfica. 3. Proteção ambiental. I. Título.

Elaborado por Maria Penha da Silva Oliveira CRB-8/6961 


\section{FOLHA DE APROVAÇÃO}

Nome: SANTOS, Bruno Raniely Gonçalves.

Título: Análise dos Critérios Adotados e dos Empreendimentos Financiados com Recursos do FEHIDRO na Bacia do Sorocaba e Médio Tietê.

Dissertação apresentada ao Programa de PósGraduação em Ciência Ambiental do Instituto de Energia e Ambiente da Universidade de São Paulo para a obtenção do título de Mestre em Ciência Ambiental.

Aprovado em:

Banca Examinadora:

Prof. Dr. Instituição

Julgamento Assinatura

Prof. Dr. Instituição Julgamento Assinatura

Prof. Dr. Instituição

Julgamento Assinatura

Prof. Dr. Instituição Julgamento Assinatura 
Dedico este trabalho aos meus pais Socorro e Neto e à minha esposa Flávia. Com todo carinho. 


\section{AGRADECIMENTOS}

À minha família e aos meus pais, Socorro e Neto, por acreditar e me apoiar em todas as situações. E por me ensinarem os valores essenciais da vida (família, honestidade e persistência).

À minha esposa Flávia, pelo companheirismo, carinho, incentivo e apoio durante todo esse tempo.

À Prof ${ }^{a}$ Ana Paula Fracalanza, pela orientação, disponibilidade, conhecimentos transmitidos e, acima de tudo, paciência e humanidade.

Aos colegas e professores do PROCAM por me incentivar constantemente em busca do conhecimento.

Aos colegas Sabespianos, pela inspiração e pela ajuda incondicional nessa jornada. 
"Conhecimento não é aquilo que você sabe, mas o que você faz com aquilo que você sabe"

Aldous Huxley 


\section{RESUMO}

SANTOS, Bruno Raniely Gonçalves. Análise dos Critérios Adotados e dos Empreendimentos Financiados com Recursos do FEHIDRO na Bacia do Sorocaba e Médio Tietê. 2018. 156 f. Dissertação (Mestrado) - Programa de Pós-Graduação em Ciência Ambiental (PROCAM), Universidade de São Paulo, São Paulo, 2018.

Os conflitos pelo uso da água vêm se tornando cada vez mais comuns, impactando diretamente no comportamento dos usuários. Com isso, é fundamental a implantação eficaz da gestão desse recurso limitado, com a priorização dos usos múltiplos e a utilização mais racional da água, tentando conciliar preservação e desenvolvimento econômico e social. Para implementar esse processo de gestão no Brasil, foram criados os instrumentos constantes nas Políticas de Recursos Hídricos Nacional e do Estado de São Paulo, com destaque para os Planos de Bacia Hidrográfica. Tratam-se de documentos de planejamento criados no âmbito dos Comitês de Bacia Hidrográfica, com a proposição de metas vinculadas à recuperação, proteção e conservação dos recursos hídricos. Essas metas devem estar condizentes com os programas de desenvolvimento e ambientais estipulados no âmbito do estado, conhecidos como Programas de Duração Continuada (PDC). E, para proporcionar suporte financeiro a esse processo de gestão, foi criado o Fundo Estadual de Recursos Hídricos (FEHIDRO). Trata-se de um Fundo Estadual responsável por financiar projetos que possam trazer benefícios diretos para a melhoria da qualidade da água na Bacia Hidrográfica. Este trabalho teve como objetivo principal analisar as características desses projetos financiados com os recursos do FEHIDRO, na Bacia Hidrográfica do Sorocaba e Médio Tietê, no período de 1995 a 2016 . E também verificar se esses projetos estão condizentes com as metas estipuladas por esse Comitê. Para isso, foi realizada uma compilação das informações disponibilizadas pelo Sistema de Informação do FEHIDRO (SinFEHIDRO), com dados pertinentes aos projetos encaminhados ao Comitê. A partir dessa análise, foi possível constatar que, no período analisado, foram encaminhados 447 empreendimentos, sendo 261 aprovados e 186 cancelados. Dos aprovados, as principais áreas financiadas foram relativas à capacitação e educação ambiental, coleta e tratamento de esgoto e destinação adequada dos resíduos sólidos. O segmento Município foi o maior tomador dos recursos (66\%), seguido da Sociedade Civil (24\%) e do Estado (10\%). Quanto às metas estipuladas pelo Plano de Bacia, a maior quantidade de projetos esteve atrelada a: educação ambiental (meta 14); alcance e manutenção de $100 \%$ na coleta e no tratamento de esgoto urbano (metas 1 e 2); implantação e adequação de sistemas de destinação final de resíduos sólidos (meta 3); e, combate aos problemas de erosão urbana (meta 7). Já, com relação aos PDCs prioritários, a maior quantidade de projetos foi enquadrada nos PDC 3 (95 projetos na área de recuperação da qualidade dos corpos de água), PDC 1 (88 projetos relacionados a estudos e levantamentos de dados na bacia) e PDC 4 (26 projetos de conservação e proteção dos corpos d'água). Assim, foi possível concluir que houve coerência entre as áreas de atuação dos projetos financiados e as metas estipuladas pelo Comitê em seu Plano de Bacia, que estão relacionados principalmente à coleta e tratamento de esgoto; à destinação adequada dos resíduos sólidos; às áreas com erosão e aos programas de educação ambiental.

Palavras-chave: Comitê de Bacia Hidrográfica. Fundo Estadual de Recursos Hídricos. Plano de Bacia Hidrográfica. Projetos Financiados. 


\begin{abstract}
SANTOS, Bruno Raniely Gonçalves. Análise dos Critérios Adotados e dos Empreendimentos Financiados com Recursos do FEHIDRO na Bacia do Sorocaba e Médio Tietê. 2018. 156 f. Thesis Master's Dissertation - Graduate Program of Environmental Science, Universidade de São Paulo, São Paulo, 2018.

Conflicts surrounding the use of water are becoming increasingly commons, impacting directly on the users' behavior. As such, it is crucial that the management of this limited resource be implemented effectively, with a focus on multiple uses and the more rational use of water, trying to reconcile its preservation with economic and social development. To implement this management process in Brazil, the instruments listed in the Policies of National Water Resources and of the State of São Paulo were created, with emphasis on the Hydrographic Basin Plans. These are planning documents created in the context of the Hydrographic Basin Committees, with the proposition of goals linked to the recovery, protection and conservation of water resources. These goals must be consistents with the development and environmental programs set out in the framework of the State, known as Programs of Continued Duration (PDC). And, to provide financial support to this management process, the State Fund for Water Resources (FEHIDRO) was created. This is a State Fund responsible for financing projects that can bring direct benefits for the improvement of water quality in the Hydrographic Basin. The main objective of this study was to analyze the characteristics of projects funded by the resources of FEHIDRO, in the Hydrographic Basin of Sorocaba and Médio Tietê, in the period from 1995 to 2016. And, also, to check if these projects are consistent with the goals set out by this Committee and with the goals adopted by the framework of the State. For this reason, a compilation of data provided by the FEHIDRO Information System (SinFEHIDRO) was performed, with relevant data for projects forwarded to the Committee. From this analysis, it was possible to observe that, in the analyzed period, 447 projects were forwarded, of which 261 were approved and 186 cancelled. Of those approved, the main areas funded were those related to environmental education and training, sewage collection and treatment and proper disposal of solid waste. The Municipal segment was the main borrower of resources (66\%), followed by the Civil Society (24\%) and the State (10\%). As to the goals stipulated by the Basin Plan, the largest quantity of projects was tied to technological capacitation and environmental education (goal 14); 100\% reach and maintenance in the collection and treatment of urban sewage (goals 1 and 2), and; deployment and the adequacy of systems for final disposal of household solid waste (goal 3). Now, with regard to the priority PDCs, the greatest quantity of projects was assigned under PDC 3 (95 projects in the area of recovery of the quality of water bodies), PDC 1 (88 projects related to studies and surveys of data in the basin) and PDC 4 (26 projects for the conservation and protection of water bodies). Thus, it was possible to conclude that there was consistency between the areas of funded projects and the goals set out by the Committee in its Basin Plan, which are mainly related to the collection and treatment of sewage; to the proper disposal of urban solid waste; to erosion area and environmental education programs.
\end{abstract}

Keywords: Hydrographic Basin Committee. State Fund for Water Resources. Hydrographic Basin Plan. Funded Projects. 


\section{LISTA DE FIGURAS}

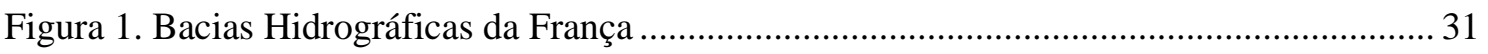

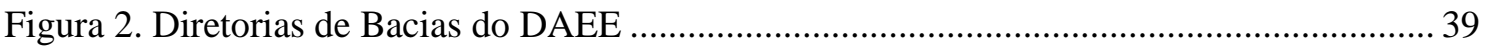

Figura 3. Princípios Básicos da Política Estadual de Recursos Hídricos .................................... 40

Figura 4. Sistema Integrado de Gerenciamento de Recursos Hídricos de São Paulo .................. 46

Figura 5. Unidades Geográficas de Gerenciamento de Recursos Hídricos do Estado de SP -

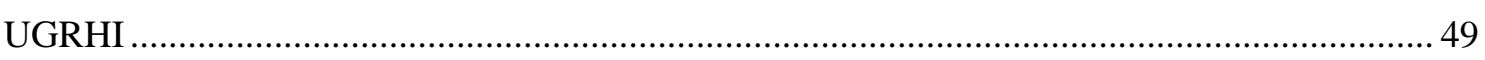

Figura 6. Etapas das tramitações dos pedidos de financiamento.................................................. 52

Figura 7. Fluxograma para a aprovação e execução dos contratos FEHIDRO: (a) fase de aprovação; (b) fase de liberação das parcelas ............................................................................... 53

Figura 8. Distribuição dos recursos do FEHIDRO provenientes da compensação financeira, agrupados por indicadores: (a) socioeconômicos; (b) criticidade hídrica; (c) planejamento e

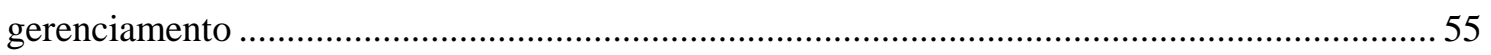

Figura 9. Panorama da Cobrança nos Comitês do Estado de São Paulo ....................................... 59

Figura 10. Localização da UGRHI 10 no Estado de São Paulo ................................................... 62

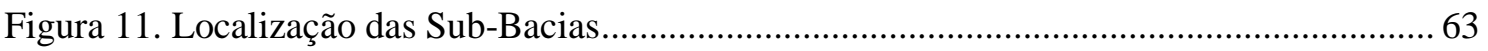

Figura 12. Distribuição dos municípios da UGRHI 10 em grupos de acordo com o IPRS ........ 69

Figura 13. Quantidade de Projetos Encaminhados e as Metas do Plano de Bacia ....................... 86

Figura 14. Número de Projetos Financiados no Comitê com relação às Metas do Plano de Bacia

Figura 15. Distribuição por segmento dos projetos financiados e concluídos com recursos

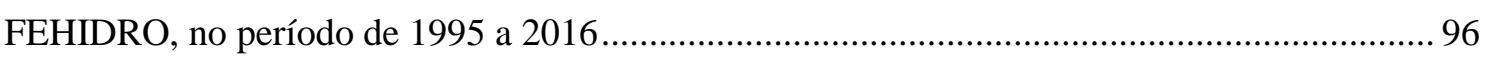

Figura 16. Quantidade de projetos cancelados e financiados por período ………....................... 97

Figura 17. Distribuição dos projetos financiados por PDC .......................................................... 98

Figura 18. Tempo médio de duração dos projetos, agrupados por: (a) Compensação; (b) Cobrança 


\section{LISTA DE QUADROS}

Quadro 1. Modelos de Gerenciamento de Recursos Hídricos............................................................. 26

Quadro 2. Programas de Duração Continuada - PDC do PERH 2016/2019 …....................................... 43

Quadro 3. Coeficientes Ponderadores utilizados na Cobrança pelo Uso da Água ................................ 57

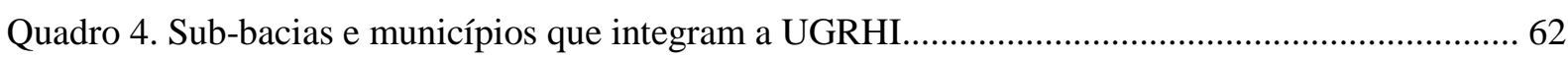

Quadro 5. Critérios adotados para a distribuição dos municípios e grupos ........................................... 68

Quadro 6. Pontuações atribuídas pelo CBH-SMT a cada critério em 2001 .......................................... 81

Quadro 7. Pontuações atribuídas pelo CBH-SMT a cada critério........................................................ 84

Quadro 8 Programas de Duração Continuada (PDC) 1 do PERH 1994/1995 ……............................. 114

Quadro 9. Programas de Duração Continuada (PDC) 2 do PERH 1994/1995 …….......................... 115

Quadro 10. Programas de Duração Continuada (PDC) 3 do PERH 1994/1995 …............................. 115

Quadro 11. Programas de Duração Continuada (PDC) 4 do PERH 1994/1995 .................................. 116

Quadro 12. Programas de Duração Continuada (PDC) 5 do PERH 1994/1995 .................................. 116

Quadro 13. Programas de Duração Continuada (PDC) 6 do PERH 1994/1995 …............................. 117

Quadro 14. Programas de Duração Continuada (PDC) 7 do PERH 1994/1995 …............................. 117

Quadro 15. Programas de Duração Continuada (PDC) 8 do PERH 1994/1995 ……......................... 118

Quadro 16. Programas de Duração Continuada (PDC) 9 do PERH 1994/1995 ................................... 118

Quadro 17. Programas de Duração Continuada (PDC) 10 do PERH 1994/1995 ................................ 119

Quadro 18. Programas de Duração Continuada (PDC) 11 do PERH 1994/1995 ............................... 119

Quadro 19. Programas de Duração Continuada (PDC) 12 do PERH 1994/1995 …............................. 119

Quadro 20. Relação dos Projetos Enviados ao CBH-SMT no período de 1995 a 2016 ..................... 120 


\section{LISTA DE TABELAS}

Tabela 1. Valores dos Coeficientes Ponderadores utilizados no Comitê do Sorocaba e Médio Tietê .. 57

Tabela 2. Distribuição das classes de uso e ocupação do Solo 64

Tabela 3. Distribuição da suscetibilidade à erosão na Bacia do Sorocaba 65

Tabela 4. As dimensões adotadas e suas respectivas contribuições para o indicador 67

Tabela 5. Permanência das Entidades da Sociedade Civil ao longo das Gestões de 1995 a 2001 72

Tabela 6. Permanência das Entidades da Sociedade Civil ao longo das Gestões de 2001 a 2007 73

Tabela 7. Permanência das Entidades da Sociedade Civil ao longo das Gestões de 2007 a 2013 74

Tabela 8. Permanência das Entidades da Sociedade Civil ao longo das Gestões de 2013 a 2015 75

Tabela 9. Compilação da participação dos representantes da Sociedade Civil em todos os mandatos. 76

Tabela 10. Relação entre os Projetos Cancelados e os financiados, no período de 1995 a 2016. 96

Tabela 11. Classificação dos Projetos Financiados quanto à abrangência territorial 100 


\section{LISTA DE SIGLAS}

ABRH Associação Brasileira de Recursos Hídricos

ANA Agência Nacional de Águas

ANEEL Agência Nacional de Energia Elétrica

APP

Área de Preservação Permanente

AT

Alto Tietê

$\mathrm{CBH}$

Comitê de Bacia Hidrográfica

CEEIBH Comitê Especial de Estudos Integrados de Bacias Hidrográficas

CEEIGUAPE Comitê Executivo de Estudos Integrados da Bacia do Rio Ribeira do Iguape

CEEIJAPI Comitê Executivo de Estudos Integrados das Bacias dos Rios Jaguari e Piracicaba

CEEIVAP Comitê Executivo de Estudos Integrados da Bacia do Rio Paraíba do Sul

CETESB Companhia Ambiental do Estado de São Paulo

CFURH Compensação Financeira pela Utilização dos Recursos Hídricos

COFEHIDRO Conselho de Orientação do Fundo Estadual de Recursos Hídricos

CORHI Comitê Coordenador do Plano Estadual de Recursos Hídricos

CRH Conselho Estadual de Recursos Hídricos

CTCOB Câmara Técnica de Cobrança

CTEEA Câmara Técnica de Eventos e Educação Ambiental

CTPA Câmara Técnica de Proteção das Águas

CTPLAGRHI Câmara Técnica de Planejamento e Gestão dos Recursos Hídricos

CTPLANFLOR Câmara Técnica Planejamento Florestal

CTSAN Câmara Técnica de Saneamento

DAEE Departamento de Águas e Energia Elétrica

DQA Diretiva-Quadro da Água

FEHIDRO Fundo Estadual de Recursos Hídricos 
FUNDAP Fundação de Desenvolvimento e Amparo à Pesquisa

GEX Grupo Executivo

IPRS Índice Paulista de Responsabilidade Social

IPT Instituto de Pesquisas Tecnológicas

MME Ministério de Minas e Energia

ONG Organização Não Governamental

PCJ Piracicaba, Capivari e Jundiaí

PDC Programa de Duração Continuada

PERH Plano Estadual de Recursos Hídricos

PNRH Política Nacional de Recursos Hídricos

PS Paraíba do Sul

SAGE Schemas d'Aménagement et de Gestion des Eaux

SDAGE Schema Directeur d'Aménagement et de Gestion des Eaux

SIGRH Sistema Integrado de Gerenciamento de Recursos Hídricos

SinFEHIDRO Sistema de Informação do Fundo Estadual de Recursos Hídricos

SINGREH Sistema Nacional de Gerenciamento de Recursos Hídricos

SMA Secretaria do Meio Ambiente

SMT Sorocaba e Médio-Tietê

UGRHI Unidade de Gerenciamento de Recursos Hídricos

WFD Water Framework Directive 


\section{SUMÁRIO}

INTRODUÇÃO ..............................................................................................................16

OBJETIVOS ……....................................................................................................................18

METODOLOGIA ….......................................................................................................19

1. UMA VISÃO TEÓRICA SOBRE O GERENCIAMENTO DAS ÁGUAS .............21

1.1 Processo Participativo e Aprendizagem Social na Gestão dos Recursos Hídricos

1.2 Gerenciamento de Recursos Hídricos: Visão Geral .......................................23

1.3 Evolução dos Modelos de Gerenciamento de Recursos Hídricos .......................25

1.4 Experiência Internacional em Gestão de Recursos Hídricos ...........................27

1.4.1 Gerenciamento nos Estados - Membros - Experiência Alemã ...........................29

1.4.2 Gerenciamento nos Estados - Membros - Experiência Francesa......................30

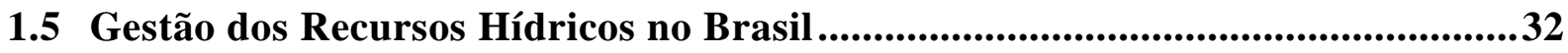

1.5.1 Política Nacional de Recursos Hídricos - Lei Federal no 9.433/97..................34

1.6 Gestão dos Recursos Hídricos no Estado de São Paulo ......................................38

1.6.1 Política Estadual de Recursos Hídricos - Lei estadual $n^{0} 7.663 / 91$..................39

1.6.2 Sistema Integrado de Gerenciamento de Recursos Hídricos ...........................45

1.7 Fundo Estadual de Recursos Hídricos - FEHIDRO ...................................51

1.7.1 Compensação Financeira ...................................................................................53

1.7.2 Cobrança pelo Uso da Água .................................................................56

1.8 Considerações Finais do Capítulo ............................................................60

2. CARACTERIZAÇÃO GERAL DA UGRHI 10: SOROCABA E MÉDIO TIETÊ 61

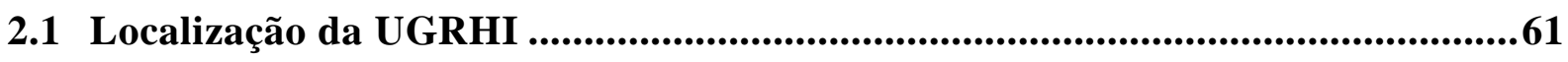

2.2 Principais Características da UGRHI .................................................63

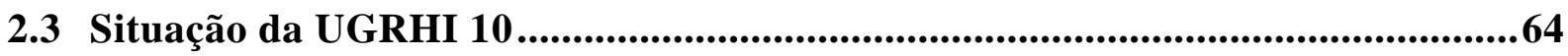

2.3.1 Uso e Ocupação do Solo...........................................................................64 
2.3.2 Saneamento Básico .66

2.3.3 Perfil Socioecônomico......................................................................................66

2.4 Gestão dos Recursos Hídricos na Bacia ........................................................69

2.4.1 Índice de Renovação do Segmento Sociedade Civil.......................................71

2.5 Considerações Finais do Capítulo ..............................................................77

3. RECURSOS FEHIDRO NA BACIA DO SOROCABA E MÉDIO TIETÊ: CRITÉRIOS DE DISTRIBUIÇÃO E CARACTERIZAÇÃO DOS PROJETOS

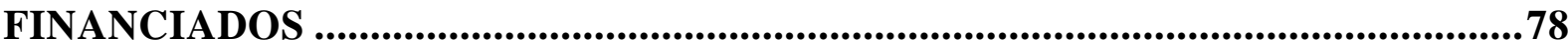

3.1 Critérios Utilizados para Hierarquização dos Projetos na Bacia do Sorocaba e Médio Tietê - Estudo das Deliberações do Comitê ....................................................78

3.1.1 Período de 1995 a 2000 ............................................................................79

3.1.2 Período de 2001 a 2009 .......................................................................80

3.1.3 Período de 2010 a 2016 .............................................................................83

3.2 Análise dos Projetos Encaminhados e Financiados pelo FEHIDRO na Bacia do Sorocaba e Médio Tietê .85

3.2.1 Projetos Encaminhados no Período de 1995 a 2016 .......................................85

3.2.2 Total de Projetos Financiados no Período de 1995 a 2016 ...............................94

3.2.3 Distribuição dos Recursos do FEHIDRO por Segmento ....................................95

3.2.4 Distribuição dos Recursos do FEHIDRO por PDC .......................................97

3.2.5 Distribuição dos Recursos do FEHIDRO por Tempo de Duração .....................99

3.2.6 Distribuição dos Recursos por Abrangência Territorial ................................100

3.3 Considerações Finais do Capítulo .............................................................101

CONSIDERAÇÕES FINAIS .....................................................................................103

REFERÊNCIAS BIBLIOGRÁFICAS ................................................................106

ANEXO 1 Caracterização dos Programas de Duração Continuada do PERH$1994 / 1995$ 114

ANEXO 2 Projetos Enviados ao CBH-SMT 120 


\section{INTRODUÇÃO}

A água é um elemento essencial à vida, exercendo grande influência para os seres vivos. Trata-se de um importante elemento representativo de valores culturais e sociais, e indispensável ao desenvolvimento das atividades humanas.

De acordo com Pompeu (2006), a água é o elemento natural, desvinculado de qualquer utilização. Por outro lado, recursos hídricos é a água como bem econômico, passível de utilização e gestão. A atribuição desse valor econômico decorre do fato de que todo recurso escasso acaba por afetar as relações econômicas, sendo assim necessário estimar seu valor (LANNA, 1993).

A atribuição do valor econômico para a água materializa-se no instrumento da cobrança pelo uso. Trata-se de um instrumento extremamente fundamental, com o objetivo de induzir ao uso mais racional, com uma gestão da demanda e uma tentativa de reduzir a descarga de efluentes sem tratamento em corpos hídricos (HESPANHOL, 2008). Os recursos arrecadados possuem como objetivo principal a recuperação e preservação dos mananciais e a implantação das ações de recuperação nas próprias bacias hidrográficas em que são gerados (VERA, 2014). Porém, segundo Hespanhol (2008), essas medidas ainda não são suficientes para manter o equilíbrio entre demanda e oferta de água, especialmente em cidades com perspectivas de crescimento populacional e industrial, onde a disponibilidade de recursos hídricos já se mostra insuficiente.

É a partir desse cenário que se faz necessária uma efetiva gestão dos recursos hídricos, com o intuito de manter a qualidade e a quantidade deste recurso, com o objetivo de evitar a sua escassez. Porém, o que acontece atualmente é uma demanda cada vez mais crescente aliada a uma oferta gradativamente reduzida, tanto pela sua degradação quanto pelo mau uso (KELMAN, 2004). Assim, torna-se cada vez mais importante a gestão da demanda com ações que visam à racionalização do uso, a partir de uma perspectiva de gestão integrada, descentralizada e participativa (RODRIGUES, 2007).

Essa gestão deve ser baseada no recorte territorial das bacias hidrográficas, com uma abordagem integrada, considerando o meio físico, biótico social, econômico e cultural. $\mathrm{O}$ foco principal deve ser a integração dos vários aspectos que interferem no uso dos recursos hídricos e na sua proteção ambiental (PORTO e PORTO, 2008).

O modelo de gestão das águas em vigor no Brasil foi fruto de uma mudança ocorrida entre os anos de 1970 e 1980. Tratou-se de uma mudança do antigo modelo de gestão "comando e controle" para um modelo mais participativo, que passou a considerar 
os impactos socioambientais e os diferentes atores no processo de tomada de decisão. Essa mudança foi sendo motivada a partir de uma série de questionamentos, por parte da sociedade civil, no que tange à centralização dos meios decisórios, à exclusão de alguns atores no processo de decisão e à maneira como vinham sendo abordados e geridos os usos da água (CAMPOS, 2008).

Diante desse cenário instaurado e na tentativa de se buscar alternativas para solucionar os problemas relacionados à água, tornou-se essencial o envolvimento da sociedade civil nos debates e nas decisões relativas a esse tema. Nesse sentido, a Lei das Águas trouxe novos paradigmas de descentralização, mecanismos que facilitaram a participação pública nas discussões e decisões conjuntas, buscando assim uma gestão mais participativa e integrada no processo de tomada de decisão (AZEVEDO, 2009)

E todo esse processo de tomada de decisão deve ser embasado nos Planos desenvolvidos nas respectivas bacias hidrográficas. Esses Planos de Bacia são documentos de planejamento e articulação das ações a serem realizadas, com metas, propostas e soluções. Essas metas devem estar condizentes com os Programas previstos no âmbito do Estado, que são conhecidos como Programas de Duração Continuada (PDCs). Esses PDCs por sua vez englobam os principais temas a serem levantados e financiados para a gestão, recuperação e proteção das bacias hidrográficas.

E, para proporcionar suporte financeiro a esse processo de gestão, foi criado o Fundo Estadual de Recursos Hídricos (FEHIDRO). Trata-se de um instrumento responsável por propiciar apoio financeiro às ações estruturais e não estruturais para a gestão de recursos hídricos nas bacias. As suas fontes de recursos são provenientes da Cobrança pelo uso de Recursos Hídricos (nas Bacias onde esse instrumento já foi implantado) e da Compensação Financeira que o Estado recebe em decorrência dos aproveitamentos hidroenergéticos em seu território (CFURH) (BRUNO et al. 2009).

Para que esse fundo tenha efetividade, deve-se assegurar que os recursos realmente irão retornar aos seus beneficiários, com aplicação direta em projetos de conservação, uso racional da água, controle e proteção dos recursos hídricos, realização de programas relativos a aproveitamento múltiplo, e proteção dos recursos hídricos, e na execução de obras de saneamento básico, entre outros (RODRIGUES, 2007).

Como essa verba repassada para o FEHIDRO é pública, sua distribuição deve seguir um processo de seleção claro e transparente. Esses critérios de distribuição dos recursos são previamente estabelecidos e divulgados por deliberações dos Comitês. Tratam-se de normas, fichas de pontuação, cronogramas das atividades, critérios de 
desempenho, entre outros critérios, que os tomadores deverão respeitar (MARTINS, 2012).

Assim, propõe-se nesta pesquisa realizar um estudo dos procedimentos adotados para a priorização de ações no Comitê de Bacia Hidrográfica dos Rios Sorocaba e Médio Tietê (UGRHI 10), a partir da análise dos projetos que foram financiados junto ao FEHIDRO, no período de 1995 a 2016, tendo como referência a atuação dos representantes ao longo dos períodos. O intervalo de tempo escolhido compreende o início da implantação do Comitê até o período de elaboração dessa dissertação.

A Bacia Hidrográfica do Sorocaba e Médio Tietê foi escolhida devido ao fato de ser uma das primeiras a implantar a cobrança pelo uso da água no Estado de São Paulo e pelo seu amadurecimento no processo de distribuição dos recursos do FEHIDRO, o que será analisado nesta dissertação.

\section{OBJETIVOS}

O principal objetivo desta pesquisa é analisar e comparar, a partir das características dos empreendimentos, como se deu a distribuição dos recursos financeiros disponíveis pelo FEHIDRO para o período de 1995 a 2016, e se os critérios adotados para essa distribuição refletem de forma clara e igualitária os objetivos assumidos pelo Comitê da Bacia Hidrográfica do Sorocaba e Médio Tietê em seu Plano de Bacia.

Para se atingir este objetivo principal, foram definidos os seguintes objetivos específicos:

$\checkmark$ Analisar os Programas de Duração Continuada (PDCs) e a sua interferência na maneira como os recursos do FEHIDRO são aplicados;

$\checkmark$ Detalhar, a partir das Deliberações do CBH-SMT e das atuações dos seus representantes, os critérios utilizados para a hierarquização dos Projetos desenvolvidos na Bacia, e as linhas temáticas utilizadas para a sua distribuição, associando-os às metas do Plano de Bacia;

$\checkmark$ Avaliar, a partir das informações do Sistema de Informação do Fundo Estadual de Recursos Hídricos (SinFEHIDRO) e dos Agentes Técnicos, as características dos projetos encaminhados e financiados, quanto a: PDC enquadrado; segmento tomador; tempo de duração do empreendimento, com foco nas maiores fragilidades da Bacia. 


\section{METODOLOGIA}

A metodologia utilizada para a elaboração dessa dissertação contou com uma ampla Revisão Bibliográfica, por meio de pesquisas em livros, teses, dissertações e artigos científicos. Também foram realizadas pesquisas em Decretos e Deliberações aprovados pelo Comitê do Sorocaba e Médio Tietê para o período de 1995 a 2016. Essas Deliberações consultadas aprovam diretrizes e critérios gerais para a distribuição dos recursos disponíveis do FEHIDRO. Os dados extraídos dessas Deliberações foram tabulados em gráficos e tabelas.

Além da pesquisa documental, foram levantadas informações complementares com agentes técnicos do governo do estado de São Paulo participantes do Sistema Estadual de Recursos Hídricos, principalmente, no que tange ao funcionamento do FEHIDRO. Também foi realizada entrevista com representante da Sociedade Civil do Comitê do Sorocaba e Médio Tietê.

O desenvolvimento da entrevista permeou alguns temas centrais, compreendendo os motivos que levaram aos critérios de pontuação adotados pelo Comitê, o processo participativo adotado entre os diversos atores, a rotatividade dos representantes entre as instituições e entre os segmentos, e o possível reflexo na qualidade dos projetos apresentados e cancelados ao longo das gestões. Também foram tratadas questões conceituais de gerenciamento de recursos hídricos, cobrança pelo uso da água e compensação financeira.

Por fim, foi realizada uma análise dos projetos financiados, a partir de dados disponibilizados pelos Agentes Técnicos e dados contidos no Sistema de Informação do FEHIDRO, objetivando detalhar suas principais características, em termos de distribuição por segmentos, por PDC, por tempo de duração e por abrangência territorial.

Todo o trabalho foi distribuído ao longo de 4 Capítulos, organizados da seguinte maneira:

O Capítulo 1 consistiu na elaboração de uma revisão bibliográfica a respeito dos temas abordados. Inicialmente foram levantados conceitos gerais sobre processo participativo e aprendizagem social na gestão dos recursos hídricos. Também foram tratadas questões de Gerenciamento de Recursos Hídricos e de modelos de Gerenciamento existentes. A abordagem consistiu desde uma visão mais global com alguns exemplos internacionais de gestão de recursos hídricos até as experiências no 
estado de São Paulo, objetivando mostrar as peculiaridades e os vínculos existentes em cada escala de gestão.

O Capítulo 2 tratou da caracterização da Bacia de estudo. Detalhou sua localização, as suas sub-bacias existentes e sua situação quanto ao Uso e Ocupação do Solo, Saneamento Básico e Perfil Socioeconômico. Por fim, trouxe um panorama da atual gestão que está sendo realizada nessa bacia, com enfoque no segmento da Sociedade Civil.

Na sequência, o Capítulo 3 mostrou os resultados e as discussões a respeito dos critérios utilizados para a hierarquização dos projetos encaminhados ao Comitê e as características dos empreendimentos que foram efetivamente financiados, com o intuito de analisar se houve coerência com as metas estipuladas no Plano de Bacia.

E, por fim, o Capítulo 4 trouxe algumas considerações finais a respeito dos temas abordados. 


\section{CAPÍTULO 1}

\section{UMA VISÃO TEÓRICA SOBRE O GERENCIAMENTO DAS ÁGUAS}

Este capítulo apresenta, inicialmente, conceitos gerais sobre processo participativo e aprendizagem social na gestão dos recursos hídricos. Em seguida são tratadas questões de gerenciamento de recursos hídricos e alguns modelos de gestão que estão sendo aplicados nessa área. São levantadas também experiências de gestão aplicadas na Alemanha, na França e no Brasil, com o intuito de demonstrar suas peculiaridades e semelhanças. No caso brasileiro, o enfoque é dado para o Estado de São Paulo. Procurou-se demonstrar as características principais da Política de Recursos Hídricos desse Estado, com ênfase para os Planos Estaduais de Recursos Hídricos e os Planos de Bacia desenvolvidos. Por fim, são elencados os aspectos gerais do Fundo de Recursos Hídricos de São Paulo, seu modo de operação e suas fontes de recursos.

\subsection{Processo Participativo e Aprendizagem Social na Gestão dos Recursos Hídricos}

O processo participativo na gestão das águas tem como propósito alcançar soluções mais democráticas para as questões socioambientais e também tentar buscar maneiras mais efetivas de gerenciar conflitos. Essa gestão se dá através de diálogos de aprendizagem e de trocas de experiências de diferentes atores sociais, com o intuito de proporcionar participações mais colaborativas (JACOBI, et. al. 2014).

Nesse contexto da gestão participativa, insere-se a Governança Ambiental. A governança deve ser entendida como uma prática contínua de desenvolvimento de poder social que possui como foco mediar as relações entre agentes econômicos, estado e sociedade civil organizada. Mais do que eliminar conflitos, a governança almeja administrá-los, de acordo com projetos coletivos. Essa mediação deve ser balizada a partir de um sistema de normas, regras e condutas que almejam espelhar os valores e visões de mundo dos atores incluídos nesse sistema. O desenvolvimento desse sistema também deve ser baseado em um processo participativo e de aprendizagem constante (FRACALANZA, 2016). 
De acordo com Gohn (2007), a Governança pode ser conceituada como sendo um paradigma da ação que possui como foco central não apenas os órgãos e aparatos estatais, mas também a interação direta do governo com a sociedade civil organizada. Para que se tenha uma boa Governança, deve haver condições factíveis de interações entre os diversos atores sociais para que os pilares do entendimento possam ser construídos.

Essa boa Governança deve ser realizada a partir da participação e do envolvimento de multi-atores, sendo que a participação de novos agentes e instituições no processo de tomada de decisão somente ocorre quando há a disseminação de determinados poderes mais centrais para as instâncias mais locais (JACOBI et al. 2015). É fundamental a participação ativa desses multi-atores na resolução de problemas de alta complexidade, não admitindo soluções simplistas, baseadas no conhecimento técnicos de poucos envolvidos (CARVALHO, 2011).

Quando se tem um adequado processo de Governança Ambiental, um de seus principais resultados é justamente a possibilidade de aprendizado social (JACOBI et al. 2015). Esse aprendizado, é proveniente principalmente das interações envolvendo os diferentes atores, o que possibilita uma compreensão melhor dos distintos posicionamentos, melhorando as relações e construindo assim uma base sólida para a cooperação consistente e articulada. É preciso entender que o conhecimento não pode ser estabelecido de forma hierarquizada, mas sim, deve ser construído a partir de uma síntese entre o analítico e aquele do dia a dia, e como ele pode ser relevante para o contexto das ações (FURNIVAL e COSTA, 2003).

A aprendizagem social possui também o intuito de proporcionar aos atores uma visão mais ampla, compreendendo que no processo participativo há uma diversidade de interesses, de argumentos e de conhecimentos. E que isso é saudável para o processo, sendo que a solução de problemas complexos só se dá através de práticas coletivas, que são baseadas na disseminação de informações e conhecimentos. Trata-se, portanto, de um conjunto de ações que estimulam as pessoas a mudarem suas práticas, gerindo processos ambientais mais sustentáveis (JACOBI, et. al. 2014).

O primeiro passo é o entendimento do problema pelos diversos atores envolvidos, para que eles possam compartilhar sua compreensão e possiblidades de intervenção sobre o mesmo. Diante desse cenário, a aprendizagem social e a cooperação tornam-se imprescindíveis para o encaminhamento das diferentes propostas apresentadas pelos atores (JACOBI, et. al. 2014). 
Porém, essa aprendizagem não é o único fator que vai determinar a postura adotada pelo representante. O que se observa, é que em alguns momentos, o posicionamento do representante é mais discreto, ou seja, ele atua apenas como um portavoz de seus representados, sem emitir opinião. Porém, em outros momentos, ele age com mais liberdade, posicionando-se e atuando em nome daqueles que ele representa. Quando analisamos a partir do conteúdo da representação, o que se observa também é uma posição ambígua por parte do representante. Em certos momentos, ele defende os interesses do seu grupo; porém, muitas vezes o que prevalece são seus próprios interesses (FREITAS, 2013).

Ao se aprofundar mais especificamente na representação do segmento Sociedade Civil, é possível observar que ela é exercida por entidades de diversos segmentos, muitas vezes conflitantes entre si. Também não fica evidente como se dá a interface dos representantes com a entidade que ele representa, bem como, qual a sua legitimidade junto ao seu público. O problema decorre do fato que os líderes não são escolhidos diretamente pela maioria do público que eles alegam representar. Diante desse contexto, o que se questiona é até que ponto a aprendizagem social dentro dos colegiados impacta na postura adotada pelos atores no processo de tomada de decisão (FREITAS, 2013). E até que ponto essa aprendizagem contribui para o melhor entendimento dos objetivos e anseios requisitados pelo Comitê para que as metas propostas em seu Plano de Bacia sejam atingidas; ou seja, para que sejam elaborados projetos que de fato irão conseguir refletir as necessidades apuradas na Bacia.

\subsection{Gerenciamento de Recursos Hídricos: Visão Geral}

Yassuda (1993, p.5) faz a seguinte indagação: "Por que a gestão dos recursos hídricos?". Por muitos anos, o setor hidrelétrico dominava as preocupações da maioria dos setores públicos responsáveis pela gestão das águas no Brasil, e como tal, a preocupação em torno dela era unicamente com relação aos aspectos quantitativos. Os demais valores da água eram tratados de forma fragmentada. Os usos e usuários não eram tratados de forma igualitária e não se fazia um planejamento adequado considerando a avaliação das múltiplas variáveis que caracterizam o seu valor. A mudança de paradigma surgiu à medida que o planejamento foi se tornando mais integrado, assegurando assim uma maior preservação, uso e recuperação desse recurso (YASSUDA, 1993). 
O gerenciamento dos recursos hídricos, segundo Freitas (2001), consiste na articulação de ações de diferentes agentes sociais, econômicos ou socioculturais, tendo como principal objetivo compatibilizar o seu uso e proteção. Para que isso ocorra, devese haver planejamento, ou seja, avaliação das demandas e das disponibilidades, bem como, sua alocação entre usos múltiplos, de forma a obter benefício social e ambiental pelo máximo período possível.

De acordo com Yassuda (1993), a gestão integrada dos recursos hídricos deve assegurar a "preservação, uso, recuperação e conservação em condições satisfatórias para os seus múltiplos usuários e de forma compatível com a eficiência e o desenvolvimento equilibrado e sustentável da região". Para se fazer uma boa gestão deve haver um conhecimento aprofundado da hidrologia regional, coordenação institucional e aparato jurídico adequado.

O desenvolvimento sustentável da região é entendido por Granziera (2014) como sendo a compatibilização do desenvolvimento econômico com a proteção ao Meio Ambiente, objetivando a permanência do equilíbrio ecológico e da qualidade de vida.

Para um adequado gerenciamento dos recursos hídricos, na visão de Coimbra (1999), deve haver uma preocupação tanto com a Base Técnica, quanto com a Base Legal e o Ordenamento Institucional. A Base Técnica tem como objetivo garantir o conhecimento dos regimes dos rios e suas sazonalidades, os regimes pluviométricos das diversas regiões hidrográficas e mais uma série de informações do ciclo hidrográfico. Já a Base Legal, serve para que o gerenciamento seja embasado em sólidos fundamentos legais e conte sempre com o apoio jurídico. O ordenamento institucional é útil no estabelecimento de uma forma sistêmica de gerenciamento, adotando a composição de colegiados em diversos níveis, tendo em vista os domínios e usos da água.

Já, para Lanna (1993), gerenciar as águas consiste em compatibilizar os diversos usos e usuários, e pode ser analisada a partir de alguns modos de planejamento, tais como: Gerenciamento dos usos setoriais da água, pelo qual são levados em consideração os planejamentos setoriais e as ações de instituições públicas e privadas, que possuem relação com diversos usos dos recursos hídricos; o Gerenciamento interinstitucional, que objetiva integrar os diversos órgãos e instituições ligados à água, com preocupação na qualidade e na quantidade; o Gerenciamento da oferta da água, que possui o papel de mostrar que o uso global dos recursos hídricos não pode ser fruto apenas das pretensões dos usuários, mas sim, da compatibilização com a disponibilidade; e o Gerenciamento 
ambiental, que se refere à utilização de padrões de qualidade ambiental a partir da utilização de instrumentos administrativos e legais.

Esses modos de planejamento mais conceituais apenas se tornam operacionais se estiverem presentes nas políticas de recursos hídricos.

\subsection{Evolução dos Modelos de Gerenciamento de Recursos Hídricos}

A evolução do processo de gerenciamento de recursos hídricos pode ser identificada a partir da análise dos modelos de gerenciamento implantados ao longo dos anos. Esses modelos estão descritos a seguir.

De acordo com Coimbra et al. (1999, p.32), modelos de gerenciamento de recursos hídricos são definidos como sendo "o arranjo institucional que contempla a definição da política hídrica e os instrumentos necessários para executá-la de forma ordenada e com papéis bem definidos de cada ator envolvido no processo". Lanna (1995), detalha os três modelos de gerenciamento mais difundidos no Brasil:

I. Burocrático: possui como principais características a racionalidade e a hierarquização das ações. Seu alicerce consiste em uma grande quantidade de Leis, Decretos, Portarias a respeito do uso e proteção ao meio ambiente. Desse modo, há uma maior concentração de poder e autoridade em entidades públicas, de natureza burocrática, que dão excessiva atenção aos aspectos formais sem considerar o dinamismo de todo o processo. Uma importante consequência desse modelo é a centralização das decisões, geralmente distante de onde surgiu a demanda, o que resulta em uma percepção de ineficiência e de falta de eficácia, comprometendo todo o sistema.

II. Econômico-Financeiro: esse modelo se utiliza de instrumentos econômicos e financeiros com o intuito de induzir à obediência às disposições legais vigentes. Sua força motora são os programas de investimentos em saneamento, irrigação, eletrificação, mineração e outros. A sua falha, assim como no modelo anterior, está no fato de não considerar o dinamismo de todo o processo.

III. Sistêmico de integração participativa: trata-se de um modelo que considera o dinamismo do processo de tomada de decisão, com o gerenciamento realizado de maneira 
compartilhada, mediante discussões e deliberações multilaterais e descentralizadas e o planejamento estratégico realizado por bacia hidrográfica.

No gerenciamento de recursos hídricos brasileiro, o modelo adotado tem sido o sistêmico participativo, devido à valorização do papel de negociação, com a criação de instâncias específicas para o processo de discussão, entre os participantes do Estado e da sociedade organizada (LEAL, 2000).

Demais modelos de gerenciamento dos recursos hídricos também são trazidos por Barth (1999). O autor descreve que há três modelos de gerenciamento: conservador, inovador e avançado. Tais modelos são analisados pelo autor segundo a aplicação de dois instrumentos de gestão: a cobrança e a outorga; e dois órgãos do sistema: a agência e os comitês de bacias (Quadro 1).

\begin{tabular}{|c|c|c|c|}
\hline & Conservador & Inovador & Avançado \\
\hline 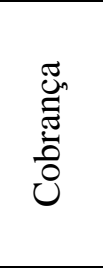 & $\begin{array}{l}\text { Forma de obter receitas para } \\
\text { as atividades de } \\
\text { gerenciamento de recursos } \\
\text { hídricos e recuperação de } \\
\text { custos de investimentos } \\
\text { públicos. }\end{array}$ & $\begin{array}{l}\text { Contribuição dos usuários para } \\
\text { melhoria da qualidade e } \\
\text { quantidade dos recursos } \\
\text { hídricos, assemelhando-se a } \\
\text { contribuições de condôminos. }\end{array}$ & $\begin{array}{c}\text { Relacionada ao } \\
\text { valor econômico da } \\
\text { água, sujeita às leis } \\
\text { do mercado. }\end{array}$ \\
\hline $\begin{array}{l}\stackrel{\pi}{0.0} \\
\stackrel{0}{0} \\
\stackrel{0}{0}\end{array}$ & $\begin{array}{l}\text { Fundamental para a proteção } \\
\text { dos direitos dos usuários, } \\
\text { intransferível e revogável a } \\
\text { qualquer tempo pelo poder } \\
\text { concedente. }\end{array}$ & $\begin{array}{l}\text { Subordinada à conciliaçãa dos } \\
\text { conflitos por negociação nos } \\
\text { Comitês de Bacia, transferível } \\
\text { no processo de negociação. }\end{array}$ & $\begin{array}{l}\text { Direito de uso } \\
\text { transacionável no } \\
\text { mercado. }\end{array}$ \\
\hline 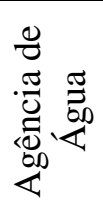 & $\begin{array}{c}\text { Executora ou operadora de } \\
\text { sistemas de fornecimento de } \\
\text { água bruta. }\end{array}$ & $\begin{array}{l}\text { Entidade de gestão dos } \\
\text { recursos financeiros obtidos } \\
\text { com a cobrança, gerida em } \\
\text { parceria do Poder Público com } \\
\text { os usuários e as comunidades. }\end{array}$ & $\begin{array}{l}\text { Simples reguladora } \\
\text { do mercado, com } \\
\text { autonomia em } \\
\text { relação ao Poder } \\
\text { Público. }\end{array}$ \\
\hline 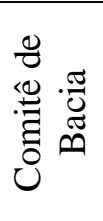 & $\begin{array}{c}\text { Somente meio de } \\
\text { interlocução do Poder } \\
\text { Público com os usuários e as } \\
\text { comunidades sem atribuição } \\
\text { deliberativa. }\end{array}$ & $\begin{array}{c}\text { Com atribuição deliberativa e } \\
\text { poder de decisão sobre os } \\
\text { valores a serem arrecadados e } \\
\text { o plano de aplicação de } \\
\text { recursos. }\end{array}$ & $\begin{array}{l}\text { Dispensável ou } \\
\text { mero supervisor da } \\
\text { Agência de Bacia. }\end{array}$ \\
\hline
\end{tabular}

Fonte: BARTH, 1999

Tendo como referência a classificação de Barth, pode-se afirmar que, para o caso do estado de São Paulo, alguns instrumentos encontram-se em diferentes fases de implementação. 
Por exemplo a outorga, a partir de 2017, vem passando por um período de transição, passando de um modelo mais conservador para inovador, principalmente devido a alguns aspectos. As novas determinações do Departamento de Águas e Energia Elétrica (DAEE), que é o órgão gestor, tornou-a transferível entre os usuários. Os comitês também passaram a poder deliberar sobre alguns parâmetros importantes (vazão de referência e vazão mínima), não ficando apenas a critério do órgão do Estado. Essas novas regras ainda estão sendo aplicadas gradualmente.

\subsection{Experiência Internacional em Gestão de Recursos Hídricos}

A escolha do tópico sobre as experiências internacionais em gestão de recursos hídricos foi motivada com o intuito de trazer exemplos de países que, de acordo com Bernal (2012), são considerados referências na gestão e os seus modelos foram utilizados para o desenvolvimento e a implantação da Política Brasileira de Recursos Hídricos, principalmente no que tange à criação dos Planos de Bacia para o processo de gestão. Segundo Correia (2005), o modelo de gestão de recursos hídricos adotado em muitos países da União Europeia (a Diretiva - Quadro da Água), é um grande laboratório para os demais países, ou seja, uma importante fonte de experiências e reflexão, que serão descritas a seguir.

De acordo com Santos (2002), a política europeia de água voltada às questões de saúde humana e do meio ambiente datam da década de 1970, com foco na qualidade da água. Os primeiros programas de ação surgiram em 1973, com a Diretiva 73/404, relativa aos lançamentos de detergentes nos rios, e foram seguidos por demais ações (Diretiva 75/440, relativas à qualidade das águas superficiais destinadas à produção de água potável; Diretiva 80/778 que estabeleceu os critérios sobre a qualidade da água para consumo humano; Diretiva 91/271 sobre tratamento de águas residuárias; e a Diretiva 91/676, sobre nitratos). Nessa época, o principal interesse era tentar padronizar as medidas ambientais por toda a Europa.

Porém, essa articulação dos países europeus desde a década de 1970 em prol da qualidade da água não resultou em uma abordagem integrada e global sobre o setor. Foi somente em 2000 que o Parlamento Europeu aprovou um amplo acordo sobre os princípios fundamentais da Gestão de Recursos Hídricos único para toda União Europeia, estabelecendo assim a Water Framework Directive (WFD), ou Diretiva-Quadro da Água 
(DQA), como é conhecida nos países de língua portuguesa (CARDOSO SILVA, et al. 2013).

Essa Diretiva objetiva estabelecer um rol de medidas aos Estados-Membros, visando promover um gerenciamento integrado, participativo e descentralizado, no âmbito das Bacias Hidrográficas. Almejava-se alcançar o "bom estado" para a maioria das águas na Europa até 2015, ou no máximo até 2027; facilitar a valoração econômica dos recursos hídricos; e tentar aumentar o nível de participação pública na gestão das águas (CARTER e HOWE, 2006).

Segundo Correia (2005), quando se fala em boa qualidade de água, a DQA não considera apenas os conceitos tradicionais de qualidade (parâmetros físicos e químicos), mas também, aborda o conceito de "bom estado" ecológico das massas de água. Isso significa dizer que para cumprir as diretrizes da DQA, os corpos hídricos devem apresentar um quadro semelhante ao obtido na ausência de impactos antrópicos. Assim, a principal preocupação é tentar alcançar e manter a integridade ecossistêmica.

Esse é, portanto, o diferencial dessa diretiva, ou seja, ela reconhece, pela primeira vez, que a biota aquática deve ser considerada como prioritária para a avaliação da qualidade da água (COLLINS et al, 2012). Ela também é importante por trazer as questões de governança à luz da gestão dos recursos hídricos, assumindo a necessidade de novas configurações institucionais e o estímulo à participação da sociedade civil na gestão das Bacias Hidrográficas (FERREIRA e SCHMIDT, 2014).

Para se alcançar tais objetivos, de acordo com a DQA, os Estados-Membro deveriam implementar determinados requisitos específicos ao longo do tempo, tais como: adaptar as diretivas em Lei Nacional e definir as Bacias Hidrográficas individuais situadas em seu território, até 2003; caracterizar os corpos de água, incluindo os que foram fortemente modificados; rever os ambientes de grande pressões e impactos, identificando os locais com risco de não atingir os objetivos ambientais de "bom estado", até 2004; tornar operacionais as redes de monitoramento, até 2006; apresentar publicamente os planos de gestão das Bacias Hidrográficas, até 2008; identificar, até 2009, com base no monitoramento e na análise das características da Bacia Hidrográfica, um programa de medidas para alcançar os objetivos ambientais da DQA (CIS, 2003).

Ainda, quanto aos objetivos, deve-se também implementar políticas de preços de água que melhorem a sustentabilidade dos recursos hídricos até 2010 e, implementar programas de medidas para alcançar os objetivos ambientais, até 2015 (CIS, 2003). Quanto à participação, de acordo com Ferreira (2014), trata-se do elemento principal da 
política da água. O sucesso da Diretiva depende da informação, da consulta e do envolvimento do público, incluindo os usuários (EC, 2000).

Para De Stefano (2010), a participação pública pode ser definida como mecanismos intencionalmente instituídos que envolvam o público leigo nas tomadas de decisão, influenciando assim nos resultados dos planos e processos de trabalho. Ainda, segundo ela, há três níveis de participação: fornecimento de acesso público às informações nas tomadas de decisão; consulta pública na elaboração dos planos; e, por fim, a participação ativa dos envolvidos nas tomadas de decisão.

De acordo com Kochskamper (2016), a participação pública é considerada o elemento central do planejamento da DQA, e o fator chave para a efetiva implementação da Diretiva. Porém, a DQA não dispõe de regras que mostram o modo como essa participação deveria ser envolvida no processo.

Com relação aos processos de gestão, de acordo com Bernal (2012), o Plano de Bacias Hidrográficas é o principal instrumento da DQA, uma vez que se trata do principal mecanismo para que os objetivos sejam implementados. Correia (2005) mostra que esses Planos devem conter a descrição das características da Região Hidrográfica, bem como apresentar um mapeamento das redes de monitoramento e uma síntese das medidas tomadas para a consulta e informação pública.

A cada seis anos, deve haver uma atualização desses planos, sendo que, se os objetivos propostos não forem alcançados, eles devem ser justificados (BERNAL, 2012).

A seguir, serão descritos os exemplos de gestão praticados na Alemanha e na França. De acordo com Moreno Júnior (2006), trata-se de países onde a gestão já está consolidada e de alguma maneira se identifica com a gestão implantada no Brasil.

\subsubsection{Gerenciamento nos Estados - Membros - Experiência Alemã}

Na Alemanha, o sistema de gestão de recursos hídricos é descentralizado. Porém, essa descentralização ocorre por órgãos regionais, e não por bacias hidrográficas. Há uma legislação nacional mínima, que geralmente é ampliada pelos estados. Os serviços de abastecimento de água e tratamento de esgoto são de responsabilidade dos municípios. A sua Lei Federal de Recursos Hídricos é de 1957, revisada em 1986 (MOTTA, 1998).

Existem diversos exemplos de associações com representantes de diversos setores, como a indústria e o ramo agrícola. Vale destacar que os governos estaduais não participam diretamente do processo administrativo, atuando apenas como fiscalizadores 
do sistema, algo essencial para o desenvolvimento de projetos hídricos de longo prazo. Há também muitos casos de consórcios municipais (ANEAM, 2015).

Com relação ao instrumento da cobrança pelo uso da água, o que prevalece na Alemanha é o princípio do "poluidor-pagador", ou seja, os usuários devem arcar com os custos dos danos causados aos recursos naturais. Sendo assim, os usuários urbanos e industriais que utilizam o meio hídrico como fonte de diluição devem pagar uma taxa federal de esgoto (CASTRO, 2012).

A essa taxa de esgoto foram incorporados incentivos aos usuários que promovam melhorias na qualidade de seus efluentes, ou seja, que conseguirem atingir os padrões de emissão antes da data constante na legislação. Tal desconto pode chegar a $75 \%$. Outro incentivo é dado para as empresas que investem em controle (MOTTA, 1998).

Do total arrecadado, 20\% são destinados à administração do sistema e o restante é destinado aos estados para que possam financiar investimentos municipais em água e esgoto (MOTTA, 1998).

Pode-se perceber que o sistema alemão, através da sua taxa de esgoto, preocupase mais com a preservação da qualidade da água do que com a questão de oferta/demanda hídrica. Estima-se que esse país não enfrentará problemas de escassez hídrica a médio prazo (CASTRO, 2012).

\subsubsection{Gerenciamento nos Estados - Membros - Experiência Francesa}

A Lei de água francesa de 1964 (conhecida como 1964 Water Act) foi importante por levar em consideração o quadro geográfico natural do ciclo da água para solucionar os diversos problemas que a envolve. Foram então delimitadas seis grandes bacias hidrográficas, sendo que, para cada uma, foram criados um Comitê e uma Agência (Figura 1). O Comitê é responsável pelo planejamento das ações e programas de intervenção na bacia. É composto por representantes dos municípios, dos usuários e por representantes do Estado. Já as Agências de Água possuem o papel de gerir os recursos financeiros da bacia, cabendo-lhes prover subsídios e empréstimos a pessoas físicas e jurídicas para a execução de obras e projetos de interesse comum (CAMPOS, 2008).

O 1964 Water Act adotou a bacia hidrográfica como unidade de Gerenciamento e introduziu de maneira formal a participação social na política de água francesa. Já, em 1992, com a promulgação da nova lei da água (1992 Water Act), houve a ampliação dessa participação social a partir da criação de dois procedimentos de planejamento 
colaborativos (BERRY e MOLLARD, 2010). Essa nova Lei foi motivada, principalmente, pela intensificação da poluição de origem agrícola e pela promulgação da Diretiva-Quadro da Água aos Estados-Membros da União Europeia (BERRETA, 2012).

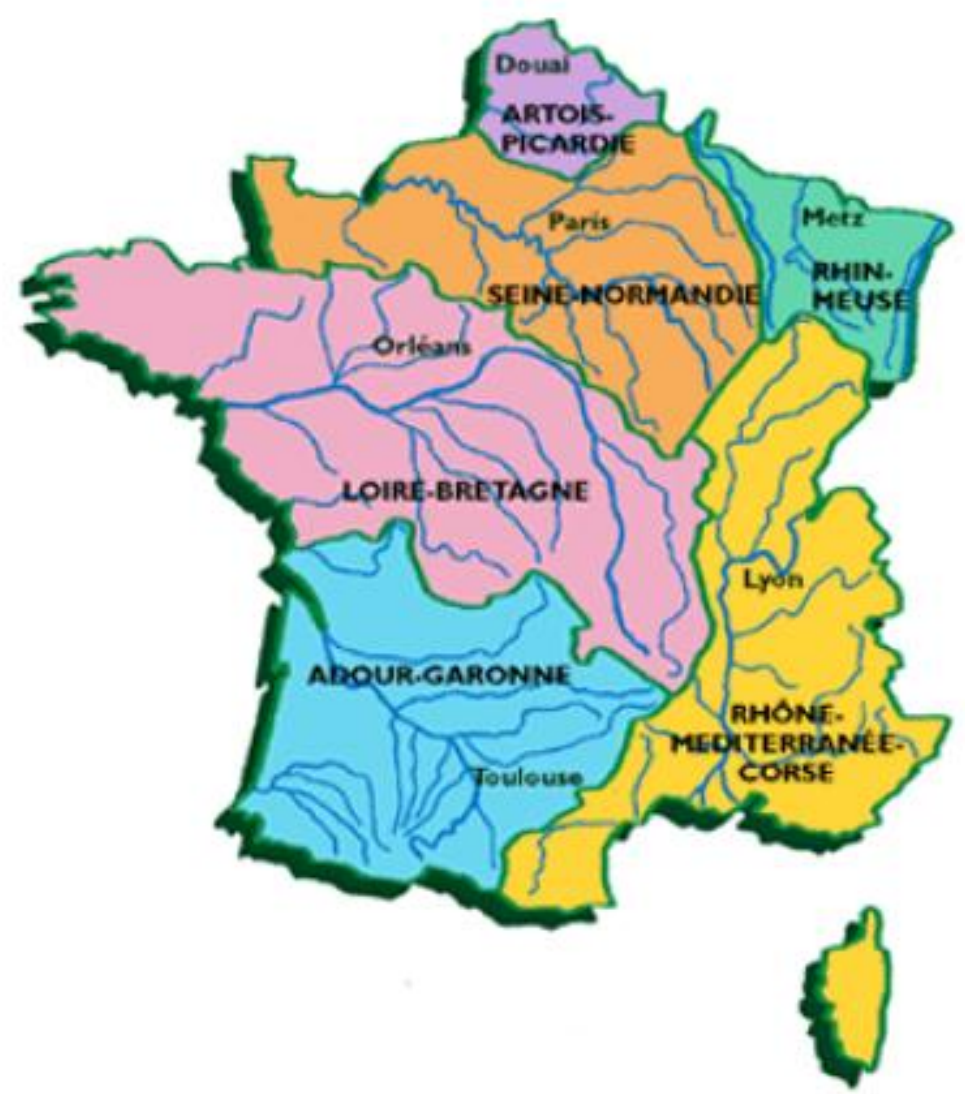

Figura 1. Bacias Hidrográficas da França Fonte: Méridianes Geo, 2017

Um desses procedimentos de planejamento colaborativo é o Schema Directeur d'Aménagement et de Gestion des Eaux (SDAGE). Trata-se de um Plano Diretor de Aproveitamento e de Gestão das Águas, de maior abrangência, com objetivos qualitativos e quantitativos dos recursos hídricos e linhas gerais de ação, levando em consideração os programas definidos pelas coletividades públicas. O SDAGE, que é elaborado pelo Comitê de Bacia, possui linhas gerais para a gestão dos recursos hídricos, considerando um horizonte de 10 a 15 anos, no âmbito das seis Agências de Água (MACHADO, 2003).

Já o segundo instrumento, o Schemas d'Aménagement et de Gestion des Eaux (SAGE), tem o foco na escala da sub-bacia. Trata-se de um Plano de Aproveitamento e de Gestão das Águas mais localizado que verifica como os objetivos definidos no plano maior estão sendo implementados. É concebido pelas Comissões Locais da Água, com 
representantes eleitos e usuários (BERRY e MOLLARD, 2010). Essas comissões são responsáveis por elaborar, revisar e acompanhar a realização do Plano (MACHADO, 2003).

Ao se adotar o perímetro do Plano de Aproveitamento, é instituída uma Comissão Local de Água, com o intuito de iniciar a elaboração do SAGE. Essa Comissão Local é formada por representantes das coletividades e estabelecimentos públicos, por diferentes representantes dos usuários da água (ribeirinhos, industriais, organizações sócioprofissionais) e representantes do Estado (BERRETA, 2012).

O Comitê de Bacia deve ser consultado, e deve se manifestar quanto à coerência do projeto de Plano de Aproveitamento. Tal projeto também é colocado à disposição do público durante dois anos nas prefeituras envolvidas. As Comissões Locais de Água têm que observar se os objetivos e as prescrições por ela definidos estão sendo respeitados, bem como elaborar um relatório anual de acompanhamento, que é transmitido ao Comitê de Bacia (MACHADO, 2003).

Os planos devem definir, principalmente, os usos prioritários e o volume total de água retirada por uso (BERRY e MOLLARD, 2010).

Em uma análise mais global, no âmbito das bacias, a Lei nº $1245 / 64$ criou as Agências Financeiras de Bacia. O objetivo era o de trazer melhorias ao sistema de distribuição de água e diminuir a poluição dos corpos hídricos, bem como, estimular os serviços públicos a utilizarem de forma mais racional os recursos hídricos, utilizando para isso instrumentos financeiros (MACHADO, 2003).

Entre as funções das Agências, têm-se que elas também são responsáveis por arrecadar os valores referentes à cobrança pelo uso da água; por participar no financiamento de obras destinadas à melhoria da disponibilidade do recurso e por distribuir empréstimos destinados a cobrir uma parte dos custos de capital das estações de tratamento locais e industriais (MACHADO, 2003).

As Agências de Bacia também possuem caráter participativo, uma vez que os integrantes do Conselho Administrativo são os representantes do Estado, da iniciativa privada e da sociedade civil (BERRY e MOLLARD, 2010).

\subsection{Gestão dos Recursos Hídricos no Brasil}

A estrutura do modelo de gestão dos recursos hídricos adotada no Brasil foi em grande parte influenciada pelo modelo implantado na França, principalmente, no que 
tange aos aspectos organizacionais, com a figura dos Comitês de Bacia e das Agências de Água com poder deliberativo, e aos aspectos econômico-financeiro, com relação à cobrança pelo uso da água. É a partir dessa ótica que analisaremos então a evolução do modelo brasileiro.

O início do século XX no Brasil foi marcado por uma considerável expansão do aproveitamento hidrelétrico. Até então, a utilização da água era apenas de interesse local para abastecimento de pequenas cidades. Com essa mudança de cenário, e a partir dos debates sobre o regime jurídico a que estavam submetidas as águas, foi promulgado o Código de Águas (Decreto 24.643/34), que constituiu um marco para o setor de energia elétrica, ao proporcionar recursos legais, econômicos e financeiros para esse setor (BARTH, 1999).

A regulamentação do Código foi realizada apenas nos itens relacionados a aproveitamento hidrelétrico, ou seja, não abarcou os temas de usos múltiplos e conservação da qualidade das águas. A partir desse hiato, os estados encontraram uma maneira de ir contra a exclusividade federal de legislar, eles passaram a legislar sobre o controle de poluição das águas (BARTH, 1999).

A reformulação do gerenciamento de recursos hídricos apenas ocorreu em 1976, com a celebração de um acordo entre o Ministério das Minas e Energia e o Governo do estado de São Paulo, com o intuito de melhorar as condições sanitárias das bacias dos rios Tietê e Cubatão, e atuar nos conflitos pelo uso da água na Região Metropolitana de São Paulo. Foram criados comitês com o intuito de promover a integração interinstitucional e intergovernamental em prol do gerenciamento dos recursos hídricos (LANNA, 1995).

A partir dos bons resultados alcançados por esse acordo, os Ministérios de Minas e Energia e do Interior criaram o Comitê Especial de Estudos Integrados de Bacias Hidrográficas (CEEIBH), em 1978, através da Portaria nº 90/1978. Esse comitê ficou responsável por promover a utilização racional dos recursos hídricos dos rios de domínio da União, e por classificar os cursos d'água. Vinculados ao CEEIBH, em inúmeras bacias hidrográficas de rios federais, foram criados comitês executivos, ainda com caráter centralizador e com atribuições apenas consultivas (SETTI, 2000).

Dentre esses comitês executivos, foram criados: o Comitê Executivo de Estudos Integrados da Bacia do Rio Paraíba do Sul (CEEIVAP), em 1979; o Comitê Executivo de Estudos Integrados das Bacias dos Rios Jaguari e Piracicaba (CEEIJAPI), em 1982; e o Comitê Executivo de Estudos Integrados da Bacia do Rio Ribeira do Iguape (CEEIGUAPE), em 1984 (BARTH, 1999). 
Em 1986, o Ministério de Minas e Energia (MME), com a intenção de propor um sistema de gerenciamento de recursos hídricos, cria um Grupo de Trabalho, com a participação de órgãos federais e estaduais. No ano seguinte, os debates intensificaramse e entenderam a necessidade de incluir segmentos sociais nas discussões. Ainda em 1987, a Associação Brasileira de Recursos Hídricos (ABRH), com a elaboração da Carta de Salvador, manifestou a necessidade de criação de um sistema nacional e do afinamento da legislação, com o intuito de contemplar o uso múltiplo, a gestão descentralizada e participativa e a capacitação do setor (ANA, 2002).

Essa Carta, aprovada no VII Simpósio Brasileiro de Recursos Hídricos, considerou, segundo a Agência Nacional de Águas (ANA), que o país deveria apoiar oportunidades de aproveitamento de recursos hídricos objetivando as múltiplas finalidades, sempre observando o contexto de desenvolvimento integrado. Ela diz também que a gestão deveria proporcionar a descentralização do processo decisório e o incentivo à criação dos planos de recursos hídricos, com o intuito de promover o uso racional e a solução dos potenciais conflitos que viessem a surgir (ANA, 2002).

A partir daí uma série de acontecimentos permitiu uma rápida evolução na gestão dos recursos hídricos. Iniciativas locais, regionais e nacionais, tanto de entidades públicas e privadas e associações técnico-científicas e profissionais, colaboraram para a construção institucional dos recursos hídricos do país, o que culminou no primeiro Projeto de Lei (PL 2249/1991) prevendo a criação do Sistema Nacional de Recursos Hídricos e definindo a Política Nacional, em 1991 (ANA, 2002). Porém, apenas em 1997 foi sancionada a Lei Federal n ${ }^{\circ}$ 9.433, que definiu a Política Nacional de Recursos Hídricos e criou o Sistema, e que será explicitada no próximo item deste trabalho.

\subsubsection{Política Nacional de Recursos Hídricos - Lei Federal n ${ }^{0}$ 9.433/97}

Após um longo debate envolvendo os poderes executivo, legislativo e setores da sociedade civil organizada, em torno da gestão das águas, foi promulgada a Lei Federal n 9.433/1997, que regulamentou o inciso XIX do artigo 21 da Constituição Federal, que previa a obrigatoriedade da União instituir um Sistema Nacional de Gerenciamento de Recursos Hídricos. A instituição dessa nova lei trouxe ao país um instrumento legal com o objetivo de garantir às gerações futuras a disponibilidade do recurso hídrico (PORTO e PORTO, 2008). 
Essa Lei mostra em seus fundamentos que a água é um bem de domínio público, limitada e dotada de valor econômico. Quanto aos usos, as prioridades são o consumo humano e dessedentação de animais. A bacia hidrográfica deve ser a unidade de planejamento e a gestão deve ser descentralizada, participativa e integrada, sempre tentando priorizar os seus usos múltiplos (BRASIL, 1997).

O primeiro Fundamento, de acordo com Leal (2000), enfatiza que a água é um bem que pertence a toda coletividade, tendo o Estado a obrigação de administrá-la. E que tal fundamento também remete ao estabelecido nos artigos 20 e 26 da Constituição Federal de 1988, ou seja, que as águas superficiais são de domínio da União e dos Estados e as águas subterrâneas são de domínio dos Estados, assim sendo, não existem águas de domínio municipal e particulares (BRASIL, 1998).

O segundo fundamento está ligado ao entendimento da escassez dos recursos hídricos, tanto no aspecto quantitativo quanto no qualitativo, ou seja, da visão da finitude da água. De acordo com Milaré (2004, p. 116):

\footnotetext{
"O recurso hídrico (águas interiores, superficiais e subterrâneas) constitui um recurso ambiental natural finito e vulnerável. Como tal, deve ser considerado nas diversas políticas públicas como um bem, dotado de valor econômico. Trata-se do princípio indutor do uso racional do recurso, dado que serve de base à instituição da cobrança para a utilização da água" (MILARÉ, 2004, p.116).
}

Granziera (2014) salienta que recurso hídrico passa a ter valor à medida que se aumenta o interesse, e ao se tornar escasso ele passa a ter valor econômico. Nesse aspecto, a Declaração de Dublin afirma em seu quarto princípio que:

\footnotetext{
"No passado, o não reconhecimento do valor econômico da água conduziu ao seu desperdício e a danos ambientais decorrentes do seu uso. A gestão da água, como bem econômico, é uma importante forma de atingir a eficiência e equidade no seu uso e de promover a sua conservação e proteção" (Declaração de Dublin, 1992, p.2).
}

Os Fundamentos $3^{\circ}$ e $4^{\circ}$ podem ser entendidos como uma maneira de garantir as necessidades essenciais de acesso à água (consumo humano e dessedentação de animais), de preservar a integridade dos ecossistemas e combater as ameaças de desertificação e de degradação ao meio ambiente. As formas de repartição (usos múltiplos) devem manter um justo equilíbrio entre os usos concorrentes e considerar o valor social, econômico e ambiental da água (GRANZIERA, 2014). 
O próximo Fundamento considera a bacia hidrográfica como sendo a unidade territorial para a implementação da Política. De acordo com Pompeu (2006), as políticas e legislações sobre as águas mostraram ao longo dos anos que a gestão dos recursos hídricos não pode ser concebida e praticada isoladamente, ela deve considerar os demais recursos naturais existentes na bacia como um todo, ou seja, o uso e ocupação do solo, aspectos quantitativos e qualitativos da água, os resíduos sólidos, entre outros, sempre contando com a participação dos usuários e da sociedade que residem na bacia (POMPEU, 2006).

O último Fundamento diz respeito ao modo da gestão. Diz que deve ser descentralizada, e deve contar com a participação do poder público, dos usuários e das comunidades. Trata-se de uma mudança significativa da maneira de gerir as águas, passando de setorial e centralizada para multissetorial, descentralizada e participativa. Essa mudança permite a tomada de decisões em um nível mais local, tendo o objetivo de evitar que as decisões sejam tomadas apenas em instâncias superiores.

Outra conquista trazida pela Lei $n^{0}$ 9.433/97 é a garantia da participação dos usuários e da sociedade civil em todas as instâncias deliberativas, desde o Conselho Nacional de Recursos Hídricos até os Comitês de Bacia Hidrográfica.

Para viabilizar a implantação da Política de Recursos Hídricos, foram criados os seguintes instrumentos de gestão da água: os planos de recursos hídricos, o enquadramento dos corpos de água em classes, a outorga de direito de uso da água, a cobrança pelo uso da água e o sistema de informação sobre recursos hídricos. Esses instrumentos possuem o objetivo de controlar e coordenar as atividades, para que os usos da água sejam compatíveis com o plano estabelecido (BRASIL, 1997).

A elaboração do Plano constitui um mecanismo de planejamento e gestão, mediante processos participativos de construção de consensos com o intuito de solucionar problemas diversos da bacia, assumindo o caráter de pacto entre os atores envolvidos nos colegiados (LEAL, 2000). Segundo Porto e Porto (2008), a participação na elaboração dos Planos dá oportunidade para a inserção da sociedade civil organizada e de agentes econômicos com interesses particulares participarem de todo o processo de negociação (PORTO e PORTO, 2008).

O próximo instrumento, o Enquadramento, visa assegurar às águas qualidade compatível com os usos mais exigentes a que forem destinados (BRASIL, 1997). Porto (2008, p.51) ressalta que o enquadramento deve ser baseado em negociações que permitam "uma melhor explicitação da relação entre usos da água e objetivos de 
qualidade pretendidos, atrelados aos custos de investimento necessários para atingilos”. Para Yassuda (1993), não é possível chegar a uma decisão equilibrada se não houver um sistema de informação confiável, baseado em um planejamento integrado regional, que consiga caracterizar, em médio e longo prazos, as metas, os objetivos, e os riscos ambientais, sociais e econômicos das várias alterativas de desenvolvimento.

Já o instrumento da Outorga é definido por Campos (2001) como sendo o instrumento de Comando e Controle em que uma determinada parte é disponibilizada para um dado uso, por um tempo limitado. Os objetivos são assegurar o controle quali/quantitativo dos recursos hídricos e proporcionar o acesso ao maior número de usuários possível. Trata-se de uma autorização condicionada de uso, emitida pela União ou pelos Estados, dependendo da dominialidade do corpo hídrico. Essa autorização é emitida pelo poder público mediante o conhecimento das disponibilidades hídricas e das demandas da região, permitindo que seja realizado um disciplinamento do tipo de atividade que se deseja implantar na bacia (PORTO e PORTO, 2008).

A Cobrança pelo Uso da Água, de acordo com a Lei Federal n ${ }^{\circ}$ 9.433/97, tem como objetivo reconhecer a água como um recurso natural escasso, com valor econômico, cujo uso deve ser cobrado. Os recursos provenientes da cobrança deverão ser aplicados prioritariamente na bacia hidrográfica em que foram gerados e deverão ser utilizados para o financiamento de estudos, programas, projetos e obras incluídas nos Planos de Recursos Hídricos (BRASIL, 1997). Na visão de Pinhati (1998), a cobrança pelo uso deve agir como um incentivo aos usuários no intuito de adotarem tecnologias e hábitos mais eficientes, ou seja, reduzindo as perdas e melhorando a qualidade dos lançamentos. Para Granziera (2014), a cobrança pelo uso da água fundamenta-se nos princípios do "poluidor-pagador" e "usuário-pagador". De acordo com o Conselho Estadual de Recursos Hídricos (1994) apud Leal (2000, p.58), o princípio do poluidor-pagador estabelece que:

\footnotetext{
"ao poluidor devem ser imputados os custos necessários à prevenção e ao combate à poluição, custos estes destinados ao poder público para manter o meio ambiente em estado aceitável. Isto significa que o custo de tais medidas deve, necessariamente, repercutir no custo dos bens e serviços que dão origem à poluição. O princípio poluidor-pagador é, pois, um princípio de alocação de custos. Não é um princípio de compensação por danos causados pela poluição. Tampouco significa que ao ser taxado pelo poder público pela poluição que causou, o poluidor estaria conquistando o direito de poluir" (CRH 1994 apud LEAL, 2000, p.58).
}

Na mesma linha, o princípio do usuário-pagador estabelece que: 
"os usuários de recursos naturais devem estar sujeitos a aplicação de instrumentos econômicos para que o uso e o aproveitamento desses recursos se processem em benefício da coletividade. O princípio fundamenta-se na ideia de que os recursos ambientais garantem bens e serviços para a coletividade como um todo. Desse modo, a apropriação desse bem ou serviço por parte de um ou de vários entes privados dá à coletividade o direito a uma compensação financeira" (CRH 1994 apud LEAL, 2000, p.59).

O último instrumento da Política de Recursos Hídricos diz respeito ao Sistema de Informações. Trata-se de um sistema de coleta, tratamento, armazenamento e recuperação de informações sobre os recursos hídrico. E para que esse sistema funcione adequadamente, deve haver uma coordenação unificada das informações bem como uma descentralização na obtenção e produção de dados e informações (BRASIL, 1997).

\subsection{Gestão dos Recursos Hídricos no Estado de São Paulo}

Em uma ordem mais hierárquica do que propriamente cronológica, o próximo tópico a ser analisado é a gestão dos recursos hídricos desenvolvida no âmbito do Estado de São Paulo.

Nas décadas de 1970 e 1980, o Estado de São Paulo passou por um intenso processo de desenvolvimento econômico, associado a uma urbanização descontrolada. Essas atividades intensificaram os processos de poluição e de apropriação não planejada dos recursos hídricos, ocasionando diversos conflitos pelo uso da água e intensa degradação desse recurso (GANZELI, 1993).

Diante desse cenário, foram realizados debates em torno de como realizar melhorias na administração dos recursos hídricos no Estado. Com o apoio técnico da Fundação de Desenvolvimento e Amparo à Pesquisa (FUNDAP), foi desenvolvido um documento técnico com diretrizes para uma melhor gestão. Esse documento mostrava que a melhor alternativa seria um gerenciamento considerando as dimensões da bacia hidrográfica, a partir de um modelo de gestão descentralizado no Estado. Como resultado dessa mobilização, foi criado em 1986, as Diretorias de Bacias Hidrográficas do DAEE (Figura 2). Vale destacar que o DAEE foi criado originalmente com o intuito de executar obras e combater enchentes, e essa reestruturação foi importante no sentido de facilitar futuramente a descentralização administrativa e a formulação de uma política mais atualizada para o setor (ALVIM, 2003).

O próximo passo no processo de descentralização da gestão foi a criação do primeiro Conselho Estadual de Recursos Hídricos, em 1987, a partir do Decreto Estadual 
$\mathrm{n}^{\circ}$ 27.576/87. O CRH foi criado com o intuito de implementar uma Política de Governo voltada aos recursos hídricos, além de estabelecer as bases técnicas e legais de estruturação do Sistema Integrado de Recursos Hídricos. Inicialmente, esse Conselho foi composto exclusivamente por órgãos e instituições do Governo, não se prevendo a importância da participação da sociedade civil e dos municípios nesse primeiro momento (GARCIA e VALENCIO, 2003).

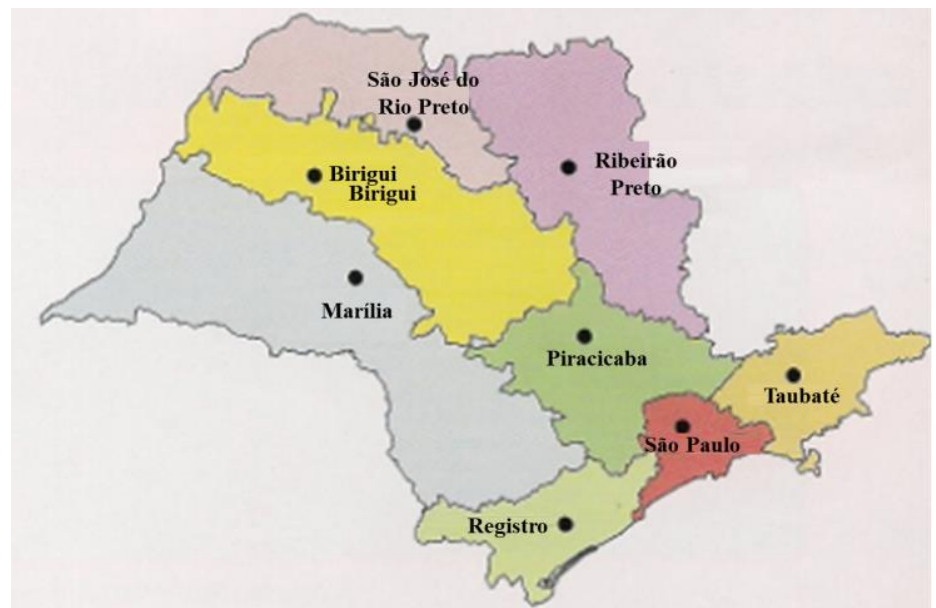

Diretorias de Bacias

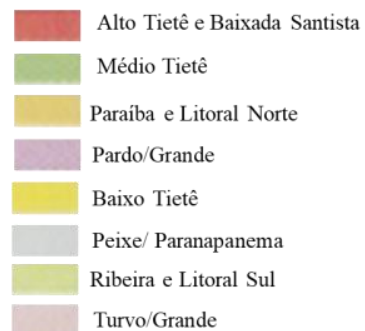

Figura 2. Diretorias de Bacias do DAEE Fonte: DAEE, 2017

E, em 1991, foi promulgada a Lei Estadual $n^{\circ} 7.663$, que estabeleceu normas de orientação à Política Estadual de Recursos Hídricos bem como ao Sistema Integrado de Gerenciamento de Recursos Hídricos (SÃO PAULO, 1991).

\subsubsection{Política Estadual de Recursos Hídricos - Lei estadual nº 7.663/91}

A política de recursos hídricos implementada no estado de São Paulo assemelhase bastante com a política nacional, uma vez que a experiência paulista serviu como um modelo para a elaboração da nacional (LEAL, 2000).

Ela está consolidada na Lei $n^{0}$ 7.663/91, que regulamentou o Artigo 205 da Constituição Estadual, principalmente com relação ao modo de gestão descentralizada, participativa e integrada, com a participação dos órgãos estaduais, municipais e da sociedade civil, a partir de um sistema integrado de gerenciamento (Figura 3).

A gestão descentralizada está relacionada à divisão do estado de São Paulo em unidades descentralizadas de gestão (22 Unidades de Gerenciamento - UGHRI que 
cobrem todo o Estado), bem como, com às instalações dos Comitês de bacias hidrográficas.

Com relação à gestão participativa, ela é formada por representantes do estado, dos municípios e da sociedade civil organizada, ou seja, trata-se de uma composição tripartite e paritária entre estes três componentes nos colegiados, nas diversas instâncias do Sistema Integrado.

A gestão integrada está relacionada à análise não desvinculada das águas superficiais e subterrâneas e da quantidade e qualidade das águas, e também deve compreender o uso e ocupação do solo e a cobertura vegetal (RAMOS, 2007).

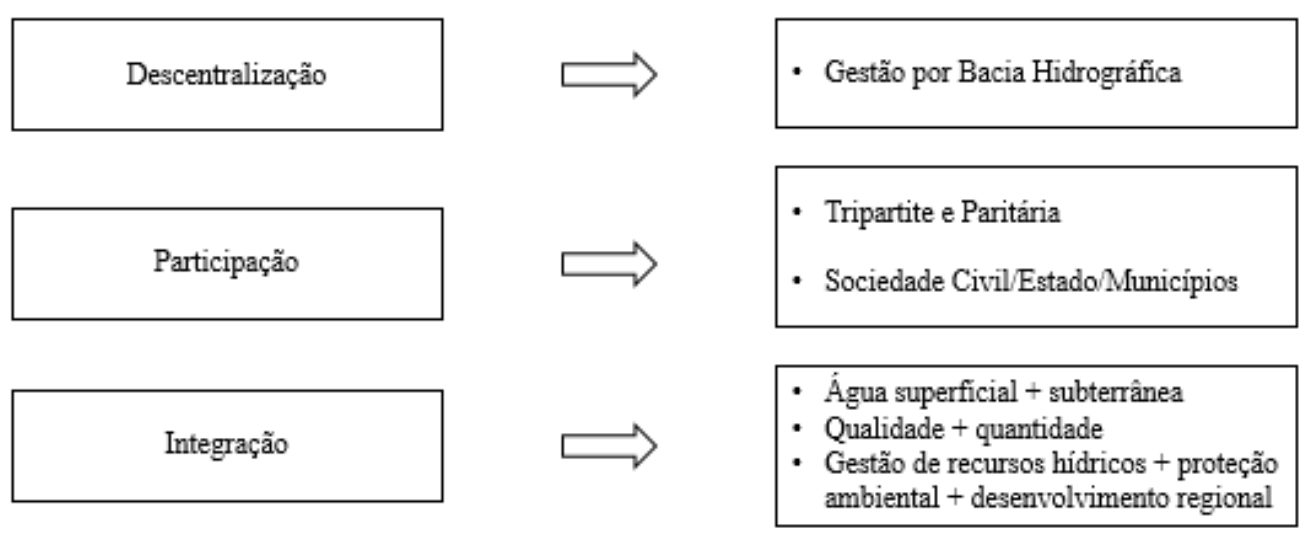

Figura 3. Princípios Básicos da Política Estadual de Recursos Hídricos Fonte: SIGRH, 2017

No âmbito das bacias hidrográficas, devem ser desenvolvidos os Planos de Bacia. Trata-se de instrumentos de planejamento e articulação das ações a serem realizadas nas bacias, baseados em metas, propostas e soluções com o intuito principal de recuperação dos recursos hídricos. Os integrantes dos comitês são responsáveis pela sua elaboração. Todo o processo de elaboração é dinâmico e evolutivo, devendo ser revisto constantemente. É fundamental que ele seja elaborado a partir de um amplo debate, por meio de negociações e articulações entre os atores envolvidos (GARCIA e VALENCIO, 2003).

A avaliação dos Planos é realizada a partir de relatórios anuais, conhecidos como "Relatórios de Situação". Esses relatórios apresentam diagnósticos da bacia e acompanham se as metas contidas nos planos estão sendo cumpridas (GARCIA e VALENCIO, 2003).

A Deliberação que aprova os critérios mínimos para a elaboração do Plano de Bacia é a CRH no 146/2012. De acordo com essa Deliberação, os Planos devem atender 
às diretrizes constantes na Política Nacional e Estadual de Recursos Hídricos. Devem também promover a gestão compartilhada a partir do envolvimento dos segmentos que integram o Comitê, bem como, estabelecer a compatibilização entre os recursos financeiros e as metas estabelecidas no Plano de Bacia, evitando a alocação de recursos em projetos que não contribuam diretamente na redução dos impactos negativos na Bacia (SÃO PAULO, 2012).

Já no âmbito do estado de São Paulo é instituído o Plano Estadual de Recursos Hídricos (PERH), que tem como base os planos de bacias hidrográficas. Ele deve conter os critérios gerais para o gerenciamento, através de metas de curto, médio e longo prazos, com o objetivo de atingir índices progressivos de recuperação, proteção e conservação dos recursos hídricos da bacia (SÃO PAULO, 1991)

O primeiro Plano Estadual elaborado foi editado em 1990 (Decreto $\mathrm{n}^{\circ}$ 32.954/91), antecedendo a própria Lei 7.663/91. O intuito desse plano era realizar um diagnóstico da situação dos recursos hídricos no Estado (ALVIM, 2003). Para o período de 1994/1995, foi elaborado mais um Plano, porém, esse aprovado por Lei (Lei Estadual n ${ }^{\circ}$ 9.034/94). Esse Plano foi importante principalmente por aprovar a divisão do Estado de SP em 22 Unidades de Gerenciamento de Recursos Hídricos, e por definir 12 Programas de Duração Continuada, que englobam os principais temas a serem levantados e financiados para a gestão, recuperação e proteção das bacias hidrográficas (PARENTE, 2007). Esses primeiros PDCs estão contemplados no Anexo 1.

Os próximos Planos foram os com vigência de 1996/1999, 2000/2003, que não trouxeram mudanças significativas nem foram aprovados por Lei. Já o Plano 2004/2007 alterou a quantidade de PDCs (passando de 12 para 8), porém, sem alterar os temas abordados (PARENTE, 2007).

Todos os Planos desenvolvidos foram compostos por metas estratégicas e metas gerais. As estratégicas têm o intuito de traduzir os objetivos permanentes do Estado, enquanto as gerais devem apresentar as ações a serem realizadas para se alcançar as estratégicas. É diante desse cenário que entram os PDCs, com o objetivo de traduzir essas metas gerais em Programas a serem desenvolvidos na bacia hidrográfica, de acordo com a prioridade de cada uma (SÃO PAULO, 2006).

Como esse novo modelo de PDCs não foi aprovado em Lei (o Plano Estadual 2004/2007 não foi aprovado em assembleia legislativa), alguns Comitês ainda enquadraram os empreendimentos nos 12 PDCs anteriores. 
Alguns anos depois, com o retorno da Coordenadoria de Recursos Hídricos à Secretaria de Saneamento e Recursos Hídricos foi elaborado o Plano Estadual 2012/2015. Esse plano não alterou a quantidade e nem o teor dos PDCs apresentados no plano anterior (SÃO PAULO, 2014).

Por fim, em 2016, foi aprovada a Lei no 16.337/2016, que estabeleceu diretrizes e critérios gerais para a elaboração e monitoramento do novo Plano Estadual de RHs, e determinou que o Plano deverá ser aprovado pelo CRH em até 180 dias a partir da sua publicação. Os novos PDCs foram revisados pelo $\mathrm{CRH}$, passando a vigorar com a seguinte descrição, exposta no Quadro 2 (SÃO PAULO, 2016).

Esses oito novos PDCs servirão de base para o enquadramento dos novos projetos a serem financiados com os recursos do FEHIDRO.

Outro importante instrumento que está diretamente relacionado aos Planos de Recursos Hídricos do Estado é a Outorga do direito de uso dos recursos hídricos. O direito de acesso à água é um direito fundamental, sendo assim, o domínio exercido pela União e Estados sobre a água não deve se traduzir em direito de propriedade; ou seja, não há o direito de usar a água como bem se entender, mas sim há o dever de fazer a gestão dos recursos hídricos com o intuito de atender às necessidades da população. Essa gestão manifesta-se a partir da emissão da outorga do direito de uso (SOUSA et al, 2006).

A outorga é um ato administrativo, de autorização ou concessão, no qual o Poder Público faculta ao outorgado a garantia de determinada vazão de água por um limitado período de tempo, nos termos e condições expressas no respectivo ato. $\mathrm{O}$ uso refere-se à captação de água para processo industrial ou irrigação, ao lançamento de efluentes industriais ou urbanos, ou ainda à construção de obras hidráulicas como barragens, canalizações de rios, execução de poços profundos, entre outros (DAEE, 2017).

O poder outorgante (Governo Federal, Estados ou Distrito Federal) é o responsável por analisar os pedidos de outorga para assegurar o controle quantitativo e qualitativo dos usos e o efetivo exercício dos direitos de acesso, com o intuito de viabilizar o atendimento aos usuários. Cabe destacar que a outorga não implica na alienação parcial das águas, que são inalienáveis, implica apenas no direito de uso por tempo determinado (KELMAN, 1997).

No Estado de São Paulo cabe ao DAEE o poder de outorgante, por intermédio do Decreto $\mathrm{n}^{\circ} 41.258 / 96$, de acordo com o artigo $7^{\circ}$ das disposições transitórias da Lei 7.663/91 (DAEE, 2017). 
Quadro 2. Programas de Duração Continuada - PDC do PERH 2016/2019

\begin{tabular}{|c|c|}
\hline $\begin{array}{c}\text { PROGRAMA DE } \\
\text { DURAÇÃO CONTINUADA } \\
- \text { PDC }\end{array}$ & DESCRIÇÃO \\
\hline $\begin{array}{c}\text { 1. Base de Dados, Cadastros, } \\
\text { Estudos e Levantamentos - } \\
\text { BASE. }\end{array}$ & $\begin{array}{l}\text { Compreende a produção de estudos técnicos e o desenvolvimento } \\
\text { de Sistemas de Informação, bem como a elaboração dos Planos de } \\
\text { Recursos Hídricos. Abrange também as atividades de } \\
\text { monitoramento e divulgação de dados relativos à qualidade e à } \\
\text { quantidade dos recursos hídricos, além de outras ações atreladas a } \\
\text { base de dados, cadastros, estudos e levantamentos. }\end{array}$ \\
\hline $\begin{array}{l}\text { 2. Gerenciamento dos Recursos } \\
\text { Hídricos - PGRH. }\end{array}$ & $\begin{array}{l}\text { Contempla as atividades de apoio às entidades básicas do SIGRH } \\
\text { e à implementação dos instrumentos previstos na Política Estadual } \\
\text { de Recursos Hídricos, assim como a articulação com os demais } \\
\text { entes federativos, suas entidades e com organismos internacionais. } \\
\text { Compreende também a promoção da participação do setor privado, } \\
\text { além de outras ações atreladas ao Gerenciamento dos Recursos } \\
\text { Hídricos. }\end{array}$ \\
\hline $\begin{array}{l}\text { 3. Recuperação da Qualidade dos } \\
\text { Corpos D' Água - RQCA. }\end{array}$ & $\begin{array}{l}\text { Abrange o tratamento dos efluentes dos sistemas de esgotamento } \\
\text { sanitário, das ETAs, dos sistemas de disposição final de resíduos } \\
\text { sólidos e das fontes difusas de poluição, bem como disposição } \\
\text { final dos lodos das ETEs e projetos e obras de prevenção e } \\
\text { contenção da erosão. Abrange também outras ações atreladas à } \\
\text { recuperação da qualidade dos corpos d'água. }\end{array}$ \\
\hline $\begin{array}{l}\text { 4. Conservação e Proteção dos } \\
\text { Corpos D’Água - CPCA. }\end{array}$ & 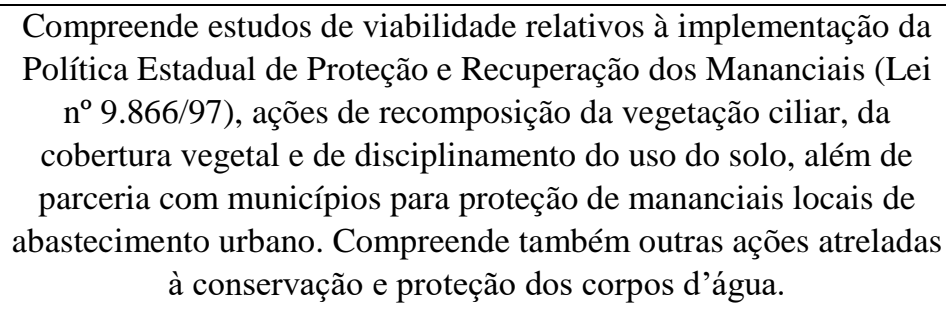 \\
\hline $\begin{array}{l}\text { 5. Promoção do Uso Racional } \\
\text { dos Recursos Hídricos - URRH. }\end{array}$ & $\begin{array}{l}\text { Contempla o fomento à racionalização do uso da água no sistema } \\
\text { de abastecimento urbano, em atividades industriais e no setor } \\
\text { agropecuário. Contempla também outras ações atreladas à } \\
\text { promoção do uso racional dos recursos hídricos. }\end{array}$ \\
\hline $\begin{array}{l}\text { 6. Aproveitamento Múltiplo dos } \\
\text { Recursos Hídricos - AMRH. }\end{array}$ & $\begin{array}{l}\text { Abrange estudos, projetos e obras de aproveitamento múltiplo dos } \\
\text { recursos hídricos, o incentivo à cogestão e rateio de custos com os } \\
\text { setores usuários. Abrange também o aproveitamento do potencial } \\
\text { da navegação fluvial e do potencial hidrelétrico remanescente, } \\
\text { além de outras ações atreladas ao aproveitamento múltiplo dos } \\
\text { recursos hídricos. }\end{array}$ \\
\hline $\begin{array}{l}\text { 7. Prevenção e Defesa contra } \\
\text { Eventos Hidrológicos Extremos } \\
\text { - PDEH. }\end{array}$ & $\begin{array}{l}\text { Compreende a elaboração de Planos de Macrodrenagem Urbana, a } \\
\text { operação de sistemas de alerta, radares meteorológicos e redes } \\
\text { telemétricas, bem como projetos e obras de desassoreamento, } \\
\text { retificação, canalização de cursos d'água e de estruturas para } \\
\text { contenção de cheias. Compreende também outras ações atreladas à } \\
\text { prevenção e defesa contra eventos hidrológicos extremos. }\end{array}$ \\
\hline $\begin{array}{c}\text { 8. Capacitação Técnica, } \\
\text { Educação Ambiental e } \\
\text { Comunicação Social - CCEA. }\end{array}$ & $\begin{array}{l}\text { Contempla treinamento, capacitação, educação ambiental e } \\
\text { comunicação social alusivos à gestão de recursos hídricos. }\end{array}$ \\
\hline
\end{tabular}


A Portaria do DAEE mais recente que dispõe sobre procedimentos da outorga de direito de uso de domínio do Estado de São Paulo é a Portaria n ${ }^{0}$ 1630/17 (que substituiu a Portaria DAEE n 717 de 12 de dezembro de 1996).

De acordo com essa Portaria, a outorga estará condicionada às prioridades de uso estabelecidas nos Planos de Bacias Hidrográficas e no Plano Estadual de Recursos Hídricos. Ela também detalha os usos que dependem de outorga:

\footnotetext{
"a execução de obras ou serviços que possam alterar o regime, a quantidade e a qualidade de recursos hídricos, superficiais ou subterrâneos; a execução de obras para extração de águas subterrâneas; a derivação de água do seu curso ou depósito, superficial ou subterrâneo, para fins de abastecimento urbano, industrial, agrícola e outros; o lançamento de efluentes nos corpos d'água, como esgotos e demais resíduos líquidos tratados, nos termos da legislação pertinente, com o fim de sua diluição, transporte ou disposição final" (DAEE, 2017, p.6).
}

A novidade trazida pela Portaria $\mathrm{n}^{0} 1630 / 17$ é que as concessões, autorizações e licenças passam a ser transferíveis, e os critérios de vazões de água considerados insignificantes passarão a ser estabelecidos nos planos de recursos hídricos. Trata-se de mudanças significativas uma vez que as definições dessas vazões insignificantes vão impactar diretamente em um outro instrumento importante, o da Cobrança pelo Uso da Água.

O instrumento da Cobrança pelo Uso da Água foi criado com o intuito de garantir o uso racional de um bem público de valor econômico. Diante desse objetivo, a cobrança no Estado de São Paulo já estava prevista na própria Constituição Estadual de 1989 (art. 211): “(...) a utilização dos recursos hídricos será cobrada segundo as peculiaridades de cada bacia hidrográfica, na forma da lei." (SÃO PAULO, 1989). Com o advento da Lei 7.663/1991, houve o reforço desse mecanismo, com a definição de critérios e metodologias. De acordo com ela, a cobrança deveria considerar a classe de uso preponderante em que for enquadrado o corpo de água, a vazão captada, o consumo efetivo, a finalidade a que se destina, entre outros (SÃO PAULO, 1991).

De acordo com Bello e Valencio (2003), a política de valoração dos recursos hídricos está baseada nos princípios “poluidor-pagador" e “usuário-pagador”. Trata-se de princípios que tentam transmitir a lógica de justiça social a partir da ideia de racionalidade econômica.

Para Granziera (2000), o princípio “poluidor-pagador” mostra que se todos têm direito a um ambiente limpo, deve o poluidor pagar pelo dano que provocou. Já o 
princípio "usuário-pagador", preconiza que se deve pagar pela utilização da água, em detrimento dos demais.

A materialização propriamente dita da Lei da Cobrança teve início com o Projeto de Lei $n^{\circ}$ 20/98. Esse PL já contava com critérios bem definidos de que tipo de utilização seria cobrada e as sanções em caso de inadimplência. Até ser aprovado, houve diversas propostas de emendas, as principais voltadas a isenções de atividades rurais (PEREIRA, 2002). Ainda no tocante ao PL, Campos e Fracalanza (2010, p.375) ressaltam que:

“(...) foi somente em 1997 que o anteprojeto de lei (PL 20) foi objeto de audiências públicas. Este anteprojeto passou por muita negociação - a maior resistência era dos usuários industriais e agrícolas e de seus 'representantes' na Assembleia Legislativa” (CAMPOS, 2008 apud CAMPOS e FRACALANZA, 2010, p.375).

E, após uma longa tramitação, o PL 20 foi retirado e substituído pelo PL 676/00, sendo então convertido na Lei $\mathrm{n}^{\circ} 12.183 / 2005$, que estabeleceu procedimentos para fixação dos limites, condicionantes e valores da cobrança em São Paulo, e que foi regulamentada pelo Decreto $\mathrm{n}^{\circ} 50.667 / 2006$.

\subsubsection{Sistema Integrado de Gerenciamento de Recursos Hídricos}

De acordo com Gomes e Barbieri (2004), o Sistema Integrado de Gerenciamento de Recursos Hídricos (SIGRH) foi implementado com o intuito de possibilitar o estabelecimento de uma rede eficiente de gerenciamento das águas no Estado de SP. Possui como objetivo principal executar a política de recursos hídricos e assegurar meios financeiros para a sua utilização, proteção e recuperação. De acordo com a Lei 7.663/91, o Sistema, cuja dinâmica é apresentada na Figura 4, é composto por:

I. Conselho Estadual de Recursos Hídricos (CRH) e Comitês de Bacias Hidrográficas $(\mathrm{CBH})$ : com caráter consultivo e deliberativo;

II. Comitê Coordenador do Plano Estadual de RHs (CORHI): de caráter mais técnico;

III. Fundo Estadual de Recursos Hídricos (FEHIDRO): trata-se da estrutura financeira. 


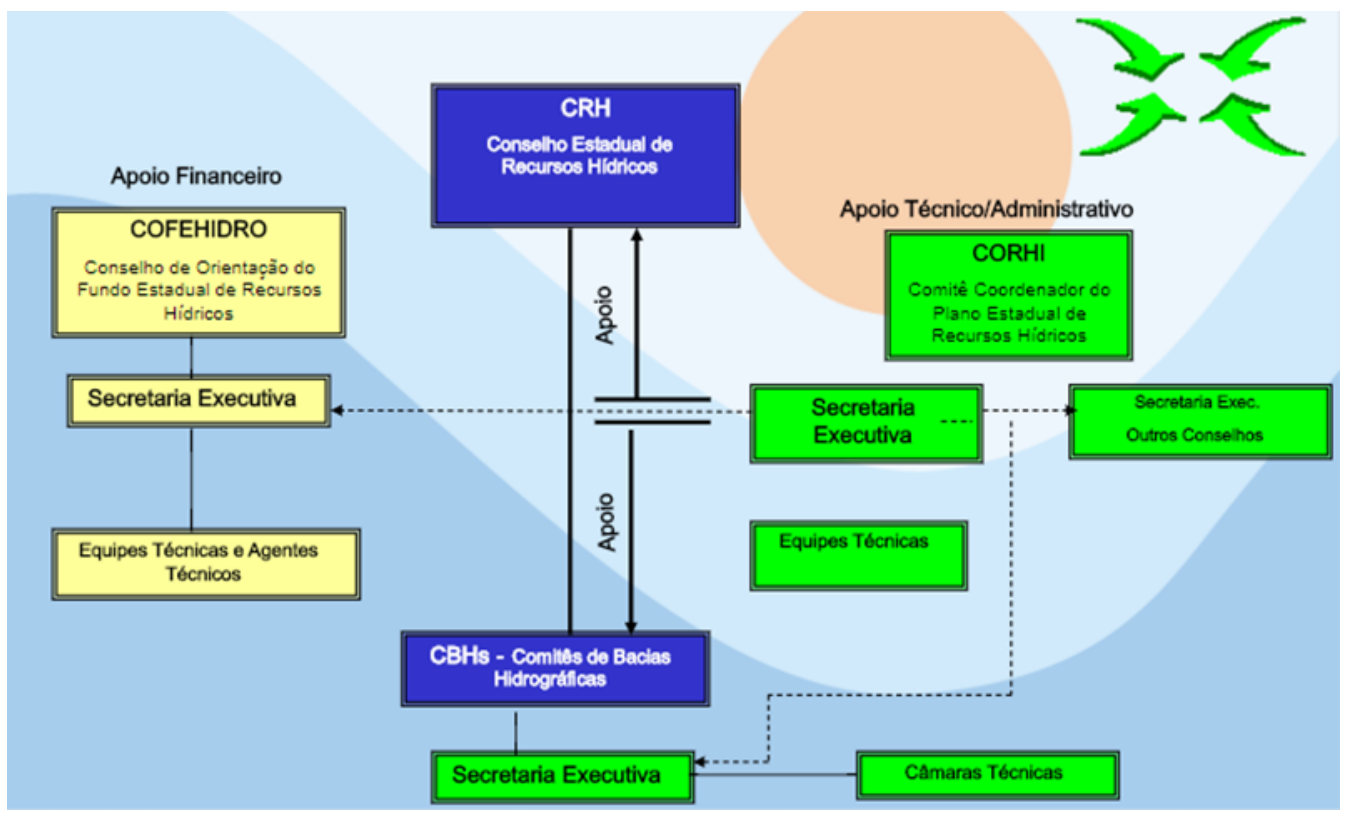

Figura 4. Sistema Integrado de Gerenciamento de Recursos Hídricos de São Paulo Fonte: SIGRH, 2017

Na sequência é realizada uma descrição sucinta dos componentes desse Sistema.

\section{Conselho Estadual de Recursos Hídricos}

O CRH é um colegiado consultivo, normativo e deliberativo, com a responsabilidade de formular, implantar, e acompanhar o desenvolvimento da Política Estadual de Recursos Hídricos. Ele é composto por representantes dos órgãos estaduais, municipais e sociedade civil (ALVIM, 2003).

Inicialmente, quando foi criado, em 1987, ele era composto apenas por representantes da Secretarias do Governo do Estado. Já possuía a incumbência de propor ações relativas à gestão de recursos hídricos de São Paulo, a estruturação do SIGRH e a elaboração de Plano Estadual de Recursos Hídricos. Contudo, em 1993, a sua estrutura foi readaptada, com base na Lei Estadual n ${ }^{\circ} 7.663 / 1991$, houve uma reformulação na sua composição, sendo atualmente formada por representantes do Estado, municípios e sociedade civil, tornando-se, desta forma, um colegiado tripartite. Esta reorganização foi resultado de articulações entre diversos segmentos sociais e de um momento de reabertura política do país que refletiu nas mais diversas instituições (ALVIM, 2003).

Atualmente, é constituído por 33 conselheiros, sendo 11 de cada segmento (Estado, município, sociedade civil). Integram o CRH os titulares, ou seus representantes, das seguintes Secretarias de Estado (SIGRH, 2017): Saneamento e Recursos Hídricos, 
que o presidirá; Meio Ambiente, que será seu vice-presidente; Educação; Planejamento e Desenvolvimento Regional; Agricultura e Abastecimento; Saúde; Logística e Transportes; Desenvolvimento Econômico, Ciência, Tecnologia e Inovação; Fazenda; Energia, e; Desenvolvimento Metropolitano (casa Civil).

São também integrantes do CRH onze representantes dos Municípios eleitos por seus pares (de cada grupo de bacia hidrográfica): $1^{\circ}$ Grupo: Alto Tietê; $2^{\circ}$ Grupo: Paraíba do Sul e Serra da Mantiqueira; $3^{\circ}$ Grupo: Litoral Norte e Baixada Santista; $4^{\circ}$ Grupo: Ribeira de Iguape/Litoral Sul e Alto Paranapanema; 5 Grupo: Médio Paranapanema e Pontal do Paranapanema; $6^{\circ}$ Grupo: Aguapeí/Peixe e Baixo Tietê; $7^{\circ}$ Grupo: Tietê/Jacaré e Tietê Batalha; $8^{\circ}$ Grupo: Turvo/Grande e São José dos Dourados; $9^{\circ}$ Grupo: Sapucaí Mirim/Grande e Pardo/Grande; 10 ${ }^{\circ}$ Grupo: Pardo e Mogi/Guaçu, e; $11^{\circ}$ Grupo: Sorocaba/Médio Tietê e Piracicaba, Capivari e Jundiaí.

E onze representantes da sociedade civil, dos seguintes segmentos: Usuários industriais de recursos hídricos, agroindustriais, agrícolas, do setor de energia elétrica, usuários de recursos hídricos para abastecimento público, associações especializadas em recursos hídricos, e entidades ambientalistas.

Possui como principais competências a aprovação de projetos de Lei relacionados ao Plano Estadual de Recursos Hídricos; a aprovação dos Relatórios de Situação; o advento de diretrizes para a elaboração de programas anuais para a aplicação dos recursos FEHIDRO, entre outras (SÃO PAULO, 1991).

\section{Comitê de Bacia Hidrográfica}

Os Comitês de bacias são colegiados regionais responsáveis pela formulação de programas e projetos a serem desenvolvidos na bacia, de acordo com as diretrizes gerais do Plano. A sua formação representa o grande diferencial no quesito políticoinstitucional, uma vez que respeita a paridade de votos entre os representantes do Estado, dos municípios e da sociedade civil organizada.

Esses colegiados possuem como característica principal a aprendizagem social, associada à articulação política e tecno-burocrática. Devem privilegiar os processos de negociações e pactos entre os vários atores envolvidos. Eles são compostos por um presidente e um vice-presidente (normalmente um prefeito e um da sociedade civil) e uma secretaria executiva (um órgão estadual, geralmente o DAEE). Com relação aos representantes do Estado, eles são eleitos entre seus pares, entretanto, as entidades do 
Estado são fixadas por lei, assim como os municípios que compõem a bacia. A sociedade civil organizada possui a maior rotatividade, uma vez que é composta por várias instituições (ONG ambientalistas, universidades, entidades de pesquisa, representantes de usuários, entre outros) (CARVALHO, 2011).

A Lei 7.663/91, complementada pela Deliberação CRH nº 02/1993, aprovou as normas gerais para composição, organização, competência e funcionamento dos Comitês de Bacias. De acordo com essa Deliberação, a participação dos integrantes se dará a partir de regras a serem definidas nos estatutos internos de cada Comitê, ou seja, de acordo com as peculiaridades regionais, porém, devendo observar as seguintes diretrizes (SÃO PAULO, 1993): no caso dos representantes dos Municípios a escolha se dará a partir de reunião plenária com a participação dos Prefeitos ou de seus representantes; os representantes do Estado deverão ser indicados por entidades que possuam atuação na bacia hidrográfica correspondente, e; os representantes da sociedade civil serão indicados por entidades que possuam sede na própria bacia hidrográfica.

Os primeiros comitês a serem criados foram os das Bacias Piracicaba, Capivari e Jundiaí (PCJ) e Alto Tietê (AT). Sua criação foi em função dos intensos problemas e conflitos em torno dos recursos hídricos nessas regiões. Posteriormente, com a criação das 22 UGRHIs a partir do Plano Estadual 1994/1995, houve a formação dos novos Comitês, tendo o Comitê do PCJ como referência. Na época foi formado um Grupo Executivo (GEX) que ficou responsável por divulgar a 7.663/91 por todos os municípios do Estado, com o intuito de motivar as pessoas na formação e participação dos Comitês. A sua maior dificuldade foi obter a participação da sociedade civil no processo (ALVIM, 2003). 


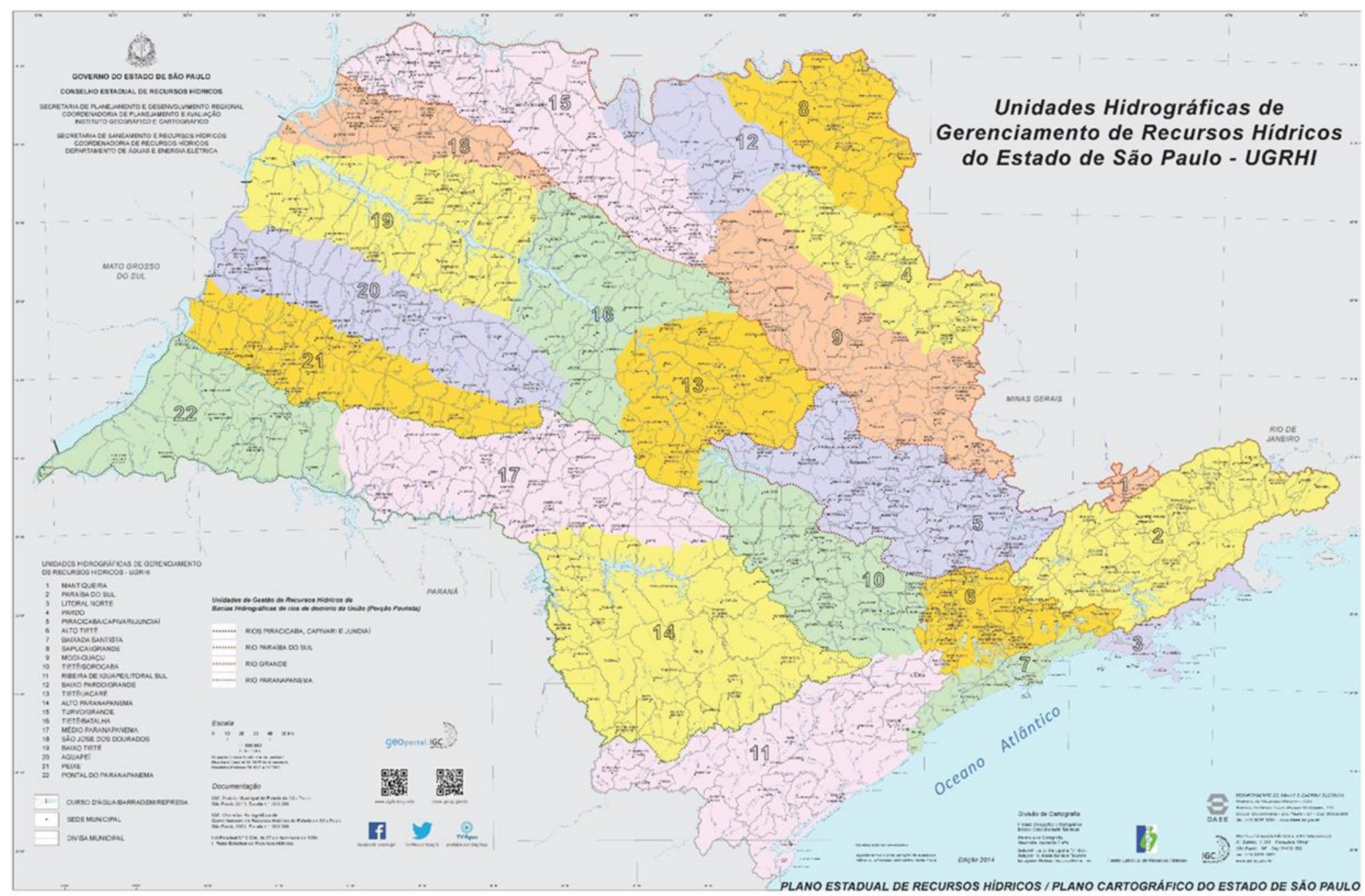

Figura 5. Unidades Geográficas de Gerenciamento de Recursos Hídricos do Estado de SP - UGRHI

Fonte: SIGRH, 2017 


\section{$\underline{\text { Comitê Coordenador do Plano Estadual de Recursos Hídricos (CORHI) }}$}

O CORHI possui a função de prestar apoio ao CRH e aos Comitês. Ele coordena a elaboração do Plano Estadual, levando em consideração todas as propostas trazidas pelos Comitês. Também deve elaborar os relatórios anuais de situação dos recursos hídricos por Bacia Hidrográfica (SIGRH, 2017).

Ele também apoia tecnicamente tanto o Conselho quanto os Comitês. Todas as propostas que são levadas para discussão ou para deliberação do Conselho devem passar primeiro pelo CORHI, onde é realizada uma análise preliminar do assunto pelos técnicos e, em seguida, são levantadas todas as documentações necessárias (ALVIM, 2003).

Sua composição é constituída por um coordenador da Coordenadoria de Recursos Hídricos, pelo representante da Secretaria do Meio Ambiente, pelo Superintendente do DAEE, pelo Presidente da Companhia Ambiental do Estado de São Paulo (CETESB) e um representante da Secretaria de Saneamento e Recursos Hídricos (SIGRH, 2017).

\section{$\underline{\text { Agências de Bacia }}$}

De acordo com a Lei 7.663/91, as Agências de Bacia são entidades jurídicas, com estruturas administrativas e financeiras próprias, exercendo as funções de Secretaria Executiva do Comitê, ou seja, trata-se de braços executivos devidamente aparelhados (SÃO PAULO, 1991).

A princípio, a criação das Agências está condicionada às Bacias onde os problemas relacionados aos recursos hídricos se justifiquem. Sua criação está vinculada à decisão do Comitê e deve ser aprovada pelo CRH. Entre suas funções, estão a elaboração dos relatórios anuais de situação dos recursos hídricos e dos planos de bacias quadrienais, submetendo-os posteriormente ao Comitê e ao CORHI, bem como, o gerenciamento financeiro dos recursos do FEHIDRO, dentro dos critérios estabelecidos pelo Comitê (SÃO PAULO, 1991).

Martins (2012), esclarece que, a Lei 7.663/91 determinava que as Agências somente poderiam ser criadas com o advento da Cobrança pelo Uso da Água na Bacia. Entretanto, a Lei Estadual no 10.020/98 autorizou a sua criação independentemente de ser instaurado o instrumento da cobrança, desde que fosse efetivada a adesão de $35 \%$ dos municípios que fazem parte da bacia e que contenham $50 \%$ da população dessa bacia (MARTINS, 2012). Essa Lei também mostra que as agências serão dirigidas por três 
órgãos com suas respectivas atribuições: o conselho deliberativo, a diretoria e o conselho fiscal (SÃO PAULO, 1998). O Conselho Deliberativo é composto por 5 membros indicados pelo Estado, e por 12 membros indicados pelo $\mathrm{CBH}$, sendo 6 dos municípios e 6 da sociedade civil, eleito entre seus pares. Já o Diretor Presidente será indicado pelo Comitê de Bacia e eleito pelo Conselho Deliberativo. Ao Conselho Fiscal compete acompanhar os atos da administração da Agência e verificar o cumprimento das normas legais, nos termos previstos no Estatuto e no Regulamento Interno.

A criação das Agências tornou-se importante pelo fato dos organismos do Estado (responsáveis pela Secretaria Executiva), não conseguirem compatibilizar suas funções cotidianas nas carreiras com as funções no Sistema, caracterizando assim nítida sobrecarga de trabalho. Diante desse cenário, as Agências viriam suprir essa necessidade, possuindo um quadro de funcionários destinados exclusivamente para desempenhar as tarefas do Sistema de Recursos Hídricos, tornando o gerenciamento mais eficiente (ALVIM, 2003).

\subsection{Fundo Estadual de Recursos Hídricos - FEHIDRO}

O FEHIDRO é a instância econômico-financeira do SIGRH, cujos recursos têm o objetivo de dar suporte financeiro à Política Estadual de Recursos Hídricos. A sua gestão é supervisionada por um Conselho de Orientação (COFEHIDRO). Esse Conselho é responsável por orientar a política de financiamento de projetos enquadrados nas prioridades estabelecidas nos Planos de Bacia, bem como, deliberar anualmente sobre o montante de recursos disponíveis para custeio que serão distribuídos entre os destinatários mediante critérios de rateio aprovados pelo Conselho Estadual de Recursos Hídricos.

O Fundo foi concebido para financiar ações na área de recursos hídricos, de médio e longo prazos, com o intuito de melhorar os processos decisórios e a eficiência na implementação das ações, impactando assim na qualidade dos corpos hídricos.

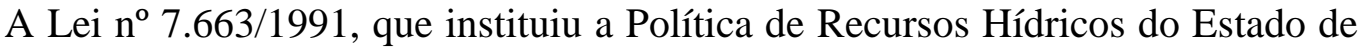
São Paulo e criou o Fundo Estadual de Recursos Hídricos, definiu que a aplicação desses recursos deverá ser orientada pelo Plano Estadual. Apesar de possibilitar duas modalidades de financiamento - reembolsável e não reembolsável (a fundo perdido) orientou que, preferencialmente, as aplicações devem ser realizadas por empréstimos, ou seja, na modalidade reembolsável (SÃO PAULO, 1991). 
O Plano Estadual de Recursos Hídricos, revisado por meio da Lei n ${ }^{\circ}$ 16.337/2016, detalha diversos Programas que englobam as principais matérias a serem tratadas visando a recuperação e a proteção das Bacias Hidrográficas, os novos PDCs, nos quais os projetos a serem financiados com os recursos do FEHIDRO devem estar enquadrados (SÃO PAULO, 2016). Tais programas haviam sido primeiramente definidos por meio da Lei ${ }^{\circ}$ 9.034/1994 (SÃO PAULO, 1994).

Os recursos do FEHIDRO provêm majoritariamente da compensação financeira que o Estado recebe em decorrência dos aproveitamentos hidroenergéticos em seu território e do resultado da cobrança pela utilização de recursos hídricos (SÃO PAULO, 1991).

De acordo com Tesch (2012), as características mais inovadoras desse fundo, estão relacionadas ao fato de seus critérios de distribuição serem definidos a partir de ampla discussão baseada nos Planos de Bacias. Os projetos financiados são decididos no Comitê, e, posteriormente, são avaliados, monitorados e referendados por Agentes Técnicos.

Quanto à estrutura organizacional, ela é composta pelo COFEHIDRO, responsável pela supervisão da aplicação dos recursos; a SECOFEHIDRO, secretaria que administra o Fundo; o Agente Financeiro, que celebra e gerencia os contratos; e os Agentes Técnicos, que emitem parecer sobre a viabilidade técnica dos empreendimentos. Nas Figuras 6 e 7, são mostradas as tramitações dos pedidos de financiamento.

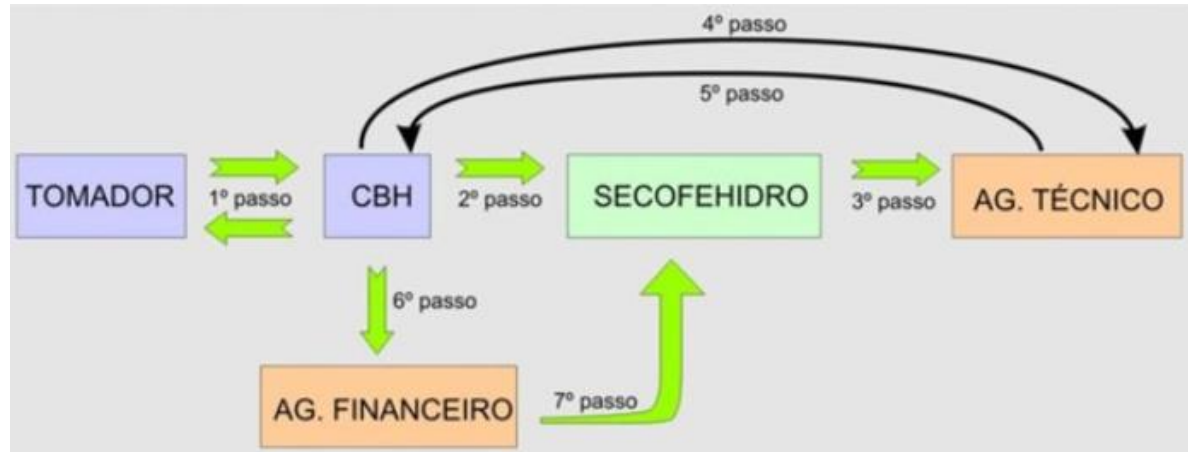

Figura 6. Etapas das tramitações dos pedidos de financiamento Fonte: FEHIDRO, 2015

Após a fase de hierarquização e seleção dos projetos ocorridas no Comitê, tem-se o seguinte fluxograma do processo (Figura 7) para a fase de aprovação e execução do contrato. 
Fase de aprovação e execução do contrato

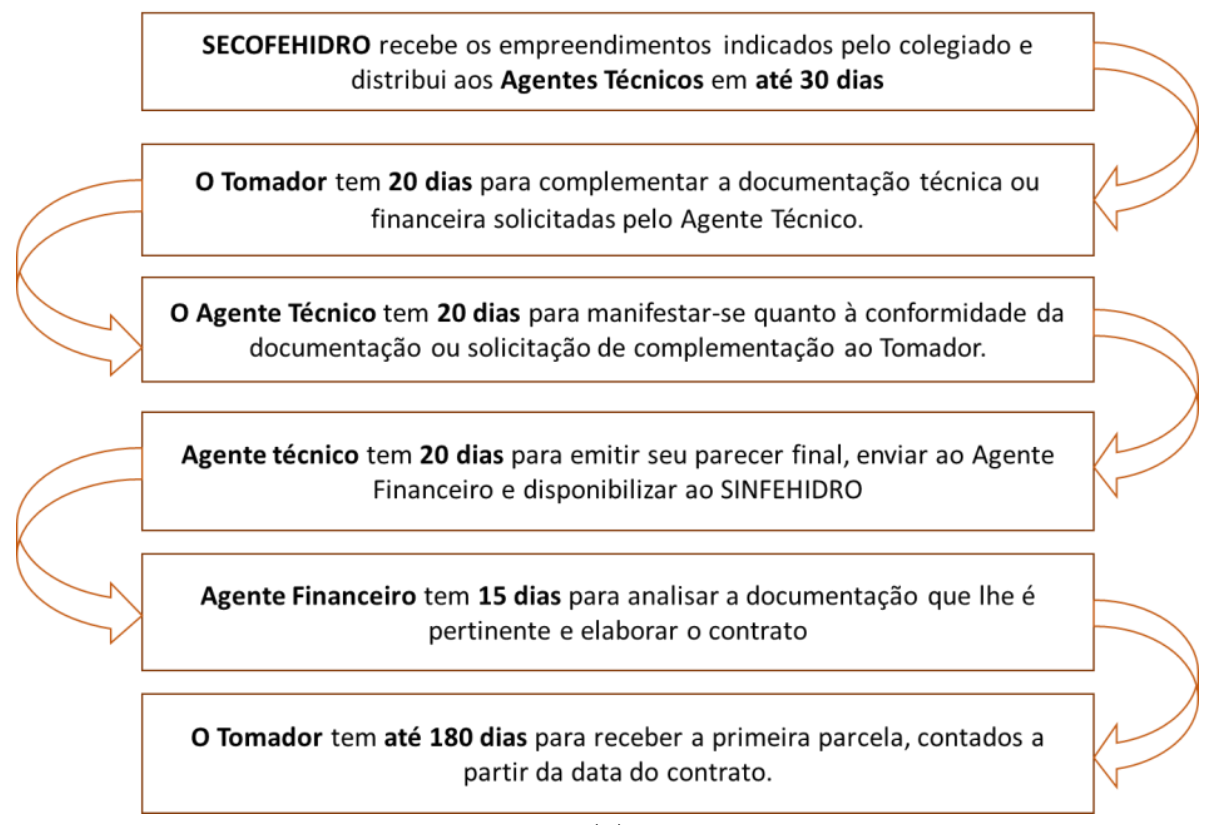

(a)

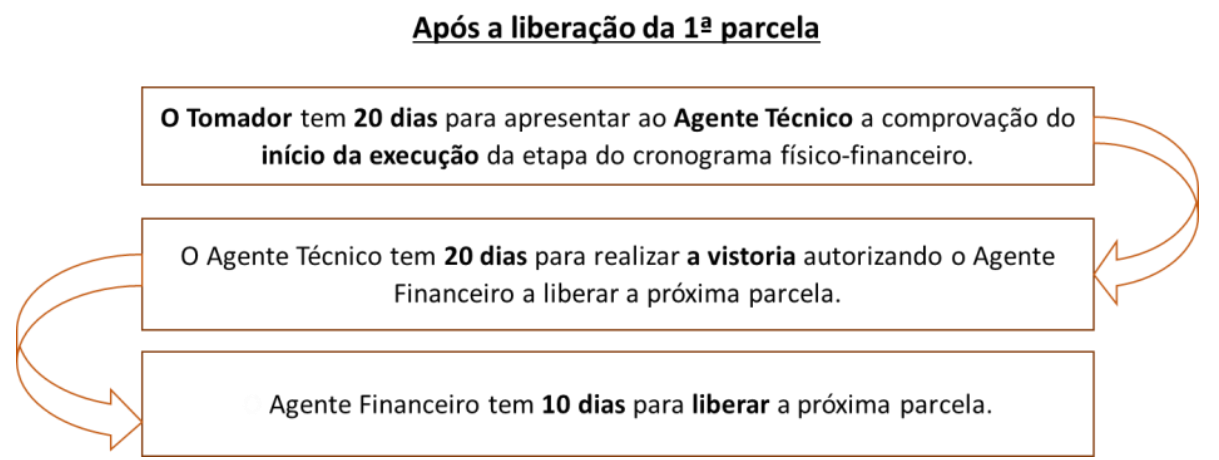

(b)

Figura 7. Fluxograma para a aprovação e execução dos contratos FEHIDRO: (a) fase de aprovação; (b) fase de liberação das parcelas

Fonte: FEHIDRO, 2015

\subsubsection{Compensação Financeira}

A Compensação Financeira foi instituída por meio da Lei ${ }^{0}$ 7.990/89. Ela é destinada aos Estados, ao Distrito Federal e aos Municípios em cujos territórios se localizarem instalações destinadas à produção de energia elétrica, ou que tenham áreas invadidas por águas dos respectivos reservatórios. Trata-se de um instrumento que busca ressarcir os municípios atingidos pela água dos reservatórios de hidrelétricas e aqueles onde se instalam as usinas.

A Lei $n^{\circ}$ 9.984/98 alterou o percentual a ser pago pelas concessionárias para exploração de potencial hidráulico (passou de 6\% para 6,75\% do valor da energia elétrica 
produzida). Desse percentual, 6\% são destinados aos Estados (45\% desse valor), Municípios (também 45\% do valor) e órgãos da adm. da União (10\%). Já os 0,75\% restantes são destinados ao Ministério do Meio Ambiente para aplicação na Política Nacional de Recursos Hídricos (PNRH) e no Sistema Nacional de Gerenciamento de Recursos Hídricos (SINGREH). O entendimento é que essa última parcela é propriamente a cobrança pelo uso da água do setor elétrico. Essas percentagens são inseridas sobre a energia total gerada, multiplicada pela tarifa vigente.

A quantificação de áreas inundadas dos municípios em cada central hidrelétrica foi estabelecida pela Resolução da Agência Nacional de Energia Elétrica (ANEEL) $n^{\circ}$ 87/2001 (CARVALHO, 2010).

Cada Estado determina qual a porcentagem da compensação financeira será destinada ao Fundo de Recursos Hídricos. No caso do Estado de São Paulo, 70\% desses recursos são destinados ao FEHIDRO, ou seja, para o financiamento de projetos voltados à melhoria da quantidade e qualidade dos recursos hídricos (porcentagem prevista em Lei). Os outros $30 \%$ vão para um fundo de pesca.

\section{Critérios de Distribuição dos Recursos da Compensação Financeira}

O Conselho Estadual de Recursos Hídricos, em sua Deliberação nº 147/2012, trata da distribuição dos recursos de investimento do FEHIDRO provenientes da compensação financeira pela utilização dos recursos hídricos para fins de geração de energia elétrica entre as Unidades de Gerenciamento paulistas. De acordo com essa Deliberação, os critérios adotados são de natureza socioeconômica, de criticidade hídrica e de planejamento e gerenciamento (SÃO PAULO, 2012).

Os indicadores socioeconômicos têm o objetivo de permitir relacionar as UGRHIs que possuem piores condições de arrecadação e riqueza. A essas UGRHIs serão destinados um valor maior de compensação, com o intuito de possibilitar aos agentes locais condições para executar ações de melhoria na gestão dos recursos hídricos. Aos três indicadores socioeconômicos são reservados $20 \%$ do total dos recursos a serem distribuídos. Tratam-se de indicadores relacionados ao Índice Paulista de Responsabilidade Social, às Áreas de Conservação e às Áreas Inundadas.

Os próximos indicadores são os relacionados à criticidade hídrica. Eles possuem o objetivo de proporcionar condições para investimentos voltados a combater as criticidades existentes. Serão reservados $40 \%$ do total dos recursos a serem distribuídos. 
Quanto maior a criticidade, maior a proporção de recursos destinados à UGRHI, de forma a manter a racionalidade de maiores criticidades significarem mais recursos, desde que, ou na proporção, que o CBH esteja aplicando seus recursos para combater a respectiva criticidade. Para esse caso, temos os seguintes indicadores: Demanda e Disponibilidade, Suscetibilidade à Erosão, Carga Orgânica Remanescente e Disponibilidade, e Vulnerabilidade à Contaminação das Águas Subterrâneas.

Por fim, há os indicadores relacionados ao planejamento e gerenciamento. $\mathrm{O}$ objetivo desses indicadores é demonstrar o avanço na implementação e no aprimoramento dos instrumentos de gerenciamento de recursos hídricos aos quais se reservaram $40 \%$ do total dos recursos. São eles: Planos de Bacia e Enquadramento dos Corpos d'água, Relatórios de Situação, Monitoramento Hidrológico e Cobrança pelo Uso da Água.

O resumo dessa distribuição pode ser observado na Figura 8.

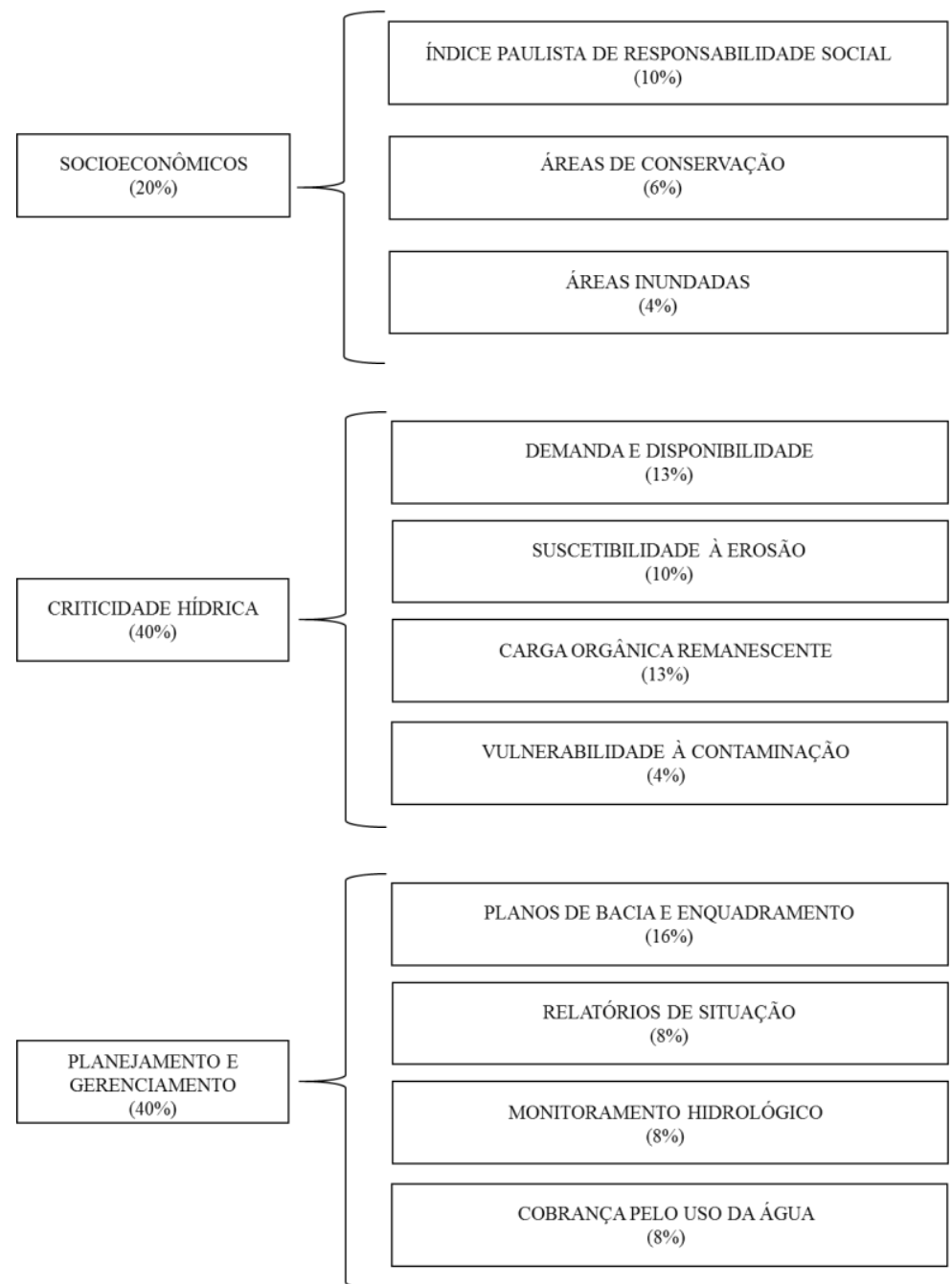

(a)

(b)

(c)

Figura 8. Distribuição dos recursos do FEHIDRO provenientes da compensação financeira, agrupados por indicadores: (a) socioeconômicos; (b) criticidade hídrica; (c) planejamento e gerenciamento

Fonte: São Paulo, 2012 


\subsubsection{Cobrança pelo Uso da Água}

\section{$\underline{\text { Mecanismos da Cobrança }}$}

Todos os usuários que utilizam os recursos hídricos estão sujeitos à cobrança, com exceção dos que utilizam água para uso doméstico de propriedades ou pequenos núcleos populacionais no meio rural, quando independer de outorga de direito de uso (SÃO PAULO, 2005). Os recursos arrecadados devem ser destinados aos comitês de bacias de origem, com o intuito de financiar estudos, programas, projetos, serviços e obras definidos nos Planos de Recursos Hídricos.

O cálculo da cobrança é baseado em três parcelas: volume de água captado, extraído ou derivado; volume de água consumido (parcela que não retorna ao manancial); e cargas lançadas nos corpos d'água. O preço final a se pagar é obtido a partir da multiplicação entre o preço unitário básico (estipulado pelo Comitê) e os coeficientes ponderadores. Esses coeficientes são utilizados com o propósito de estimular determinado tipo de uso em detrimento de outros (DAEE, 2005).

De acordo com DAEE (2005, p.3):

\footnotetext{
"Os coeficientes ponderadores retratam as diferentes condições dos usuários, entre outras: do tipo do manancial, da classe do rio, da finalidade, da localização quanto à zona de recarga de aqüíferos, e da sazonalidade, visando incorporar as peculiaridades regionais e locais. Por exemplo, a abundância ou a escassez de recursos hídricos, e os seus reflexos nos preços, seriam representados através desses coeficientes multiplicadores" (DAEE, 2005, p.3).
}

Pode-se afirmar que há diferença entre os coeficientes ponderadores, com o intuito de incentivar ou penalizar os usuários, permitindo a diferenciação dos valores a serem cobrados. O Decreto Estadual $\mathrm{n}^{\mathrm{o}} 50.667 / 06$ detalha os treze coeficientes ponderadores existentes no estado de São Paulo, apresentados no Quadro 3.

Os seus valores são estipulados pelos Comitês e devem ser referendados pelo Conselho Estadual. Tomando como exemplo o Comitê do Sorocaba e Médio Tietê, são apresentados os valores dos coeficientes adotados (Tabela 1). 
Quadro 3. Coeficientes Ponderadores utilizados na Cobrança pelo Uso da Água

\begin{tabular}{|c|c|}
\hline \multicolumn{2}{|c|}{ COEFICIENTES PONDERADORES } \\
\hline $\mathrm{X}_{1}$ & Natureza do corpo d'agua, superficial ou subterrâneo \\
\hline $\mathrm{X}_{2}$ & Classe de uso preponderante em que estiver enquadrado o corpo d'agua \\
\hline $\mathrm{X}_{3}$ & Disponibilidade hídrica local \\
\hline $\mathrm{X}_{4}$ & Grau de regularização assegurado por obras hidráulicas \\
\hline $\mathrm{X}_{5}$ & Colume captado, extraído ou derivado e seu regime de variação \\
\hline $\mathrm{X}_{6}$ & Finalidade do uso, público, alternativa ou industrial \\
\hline $\mathrm{X}_{7}$ & Características dos aquíferos \\
\hline $\mathrm{X}_{8}$ & Transposição de bacia, existente ou não \\
\hline $\mathrm{X}_{9}$ & Características físico-químicas e biológicas da água \\
\hline $\mathrm{X}_{10}$ & Localização do usuário na bacia de conservação e manejo do solo e da água \\
\hline $\mathrm{X}_{11}$ & Colume consumido \\
\hline $\mathrm{X}_{12}$ & $\mathrm{X}_{13}$ \\
\hline \hline
\end{tabular}

Fonte: SÃO PAULO, 2006

Tabela 1. Valores dos Coeficientes Ponderadores utilizados no Comitê do Sorocaba e Médio Tietê

\begin{tabular}{|c|c|c|c|}
\hline \multicolumn{4}{|c|}{ Captação, Extração, Derivação } \\
\hline \multirow{2}{*}{ Natureza do corpo d'água } & \multirow{2}{*}{$\mathrm{X}_{1}$} & Superficial & 0,90 \\
\hline & & Subterrâneo & 1,00 \\
\hline \multirow{4}{*}{$\begin{array}{l}\text { Classe do uso preponderante em } \\
\text { que estiver enquadrado o corpo } \\
\text { d'água no local do uso ou da } \\
\text { derivação }\end{array}$} & \multirow{4}{*}{$\mathrm{X}_{2}$} & Classe 1 & 1,10 \\
\hline & & Classe 2 & 1,00 \\
\hline & & Classe 3 & 0,95 \\
\hline & & Classe 4 & 0,90 \\
\hline \multirow{2}{*}{ Disponibilidade hidrica local } & \multirow{2}{*}{$\mathrm{X}_{3}$} & Crítica & 1,00 \\
\hline & & Média & 0,95 \\
\hline \multirow{2}{*}{$\begin{array}{l}\text { Volume captado, extraido ou } \\
\text { derivado e seu regime de variação }\end{array}$} & \multirow{2}{*}{$\mathrm{X}_{5}$} & Sem medição & 1,00 \\
\hline & & Com medição & 0,90 \\
\hline \multirow{2}{*}{ Finalidade de uso } & \multirow{2}{*}{$\mathrm{X}_{7}$} & Sistema Público & 1,00 \\
\hline & & Solução Alternativa & 1,00 \\
\hline \multirow{2}{*}{ Transposição de bacia } & \multirow{2}{*}{$\mathrm{X}_{13}$} & Existente & 1,50 \\
\hline & & Não Existente & 1,00 \\
\hline
\end{tabular}

Fonte: SÃO PAULO, 2009 
A partir dos valores dos coeficientes ponderadores apresentados na Tabela 1, pode-se observar que, esse Comitê privilegiou a captação superficial frente à subterrânea. Também incentivou a captação em rios de classe 3 e 4, e em áreas com disponibilidade hídrica média. Os usuários que possuem medidores também receberam um incentivo. Quanto à finalidade de uso, o Comitê não optou por fazer diferenciações, deixando o valor de 1,0 para todos. Já os usuários que pretendem utilizar a água em outra bacia, ou seja, realizar uma transposição, serão penalizados.

\section{Caracterização do Preço Unitário}

Thomas (2002) traz dois exemplos de metodologias que podem ser utilizados para definição dos preços. O primeiro é a metodologia de determinação do preço unitário com objetivo de financiamento. Esse financiamento corresponde à cobertura dos custos da bacia, ou seja, dos custos de gestão e de investimento. Ainda referente ao objetivo de financiamento, há dois modos de cobrança: aquele que é baseado no preço médio e o baseado no preço público.

O modo relacionado ao preço médio é caracterizado pela divisão do montante entre os usuários. Nesse caso, todos os usuários pagam valores iguais. Já no modo de preço público, o rateio é diferenciado em função da elasticidade da demanda de cada usuário.

O segundo exemplo de metodologia detalhado por Thomas (2002) é a metodologia de determinação do preço com o objetivo de incentivar a racionalização do uso da água. Os métodos envolvidos são: o preço ótimo e o custo-efetividade. O preço ótimo é aquele que é representado pelo ponto onde os benefícios marginais se igualam aos custos marginais.

Já no método custo-efetividade, ocorre um acordo com a sociedade quanto à quantidade ótima de água. Esse método deve fornecer justamente o custo mínimo para se atingir essa quantidade ótima sugerida.

Tomando-se como exemplo o caso do Sorocaba, o valor do Preço Unitário Básico utilizado foi devido a três fatores: custos de manutenção da cobrança e da agência; valores cobrados por outros comitês; e negociação entre comitê e usuários. 


\section{$\underline{\text { Situação da Cobrança no Estado de São Paulo }}$}

De acordo com o SigRH (2017), os dois primeiros Comitês do Estado de São Paulo a implantar o instrumento da cobrança foram os da bacia Piracicaba, Capivari e Jundiaí (PCJ) e os da bacia Paraíba do Sul (PS), ambos em 2007. O próximo Comitê a implantar foi o Sorocaba e Médio Tietê, em 2010. Em 2012, foi a vez da Baixada Santista, seguida pelo Baixo Tietê (em 2013) e Alto Tietê (em 2014). Em 2016, o Tietê Jacaré, o Tietê Batalha e o Ribeira de Iguape e Litoral Sul entraram em cobrança. Agora em 2017, foi a vez da bacia do rio do Pardo. Sendo assim, até o presente momento, a cobrança pelo uso da água está sendo efetuada em dez bacias hidrográficas do Estado de São Paulo. Os demais encontram-se em diferentes estágios de implantação (aprovada por Decreto do Governador ou em elaboração), como demonstrado na Figura 9.

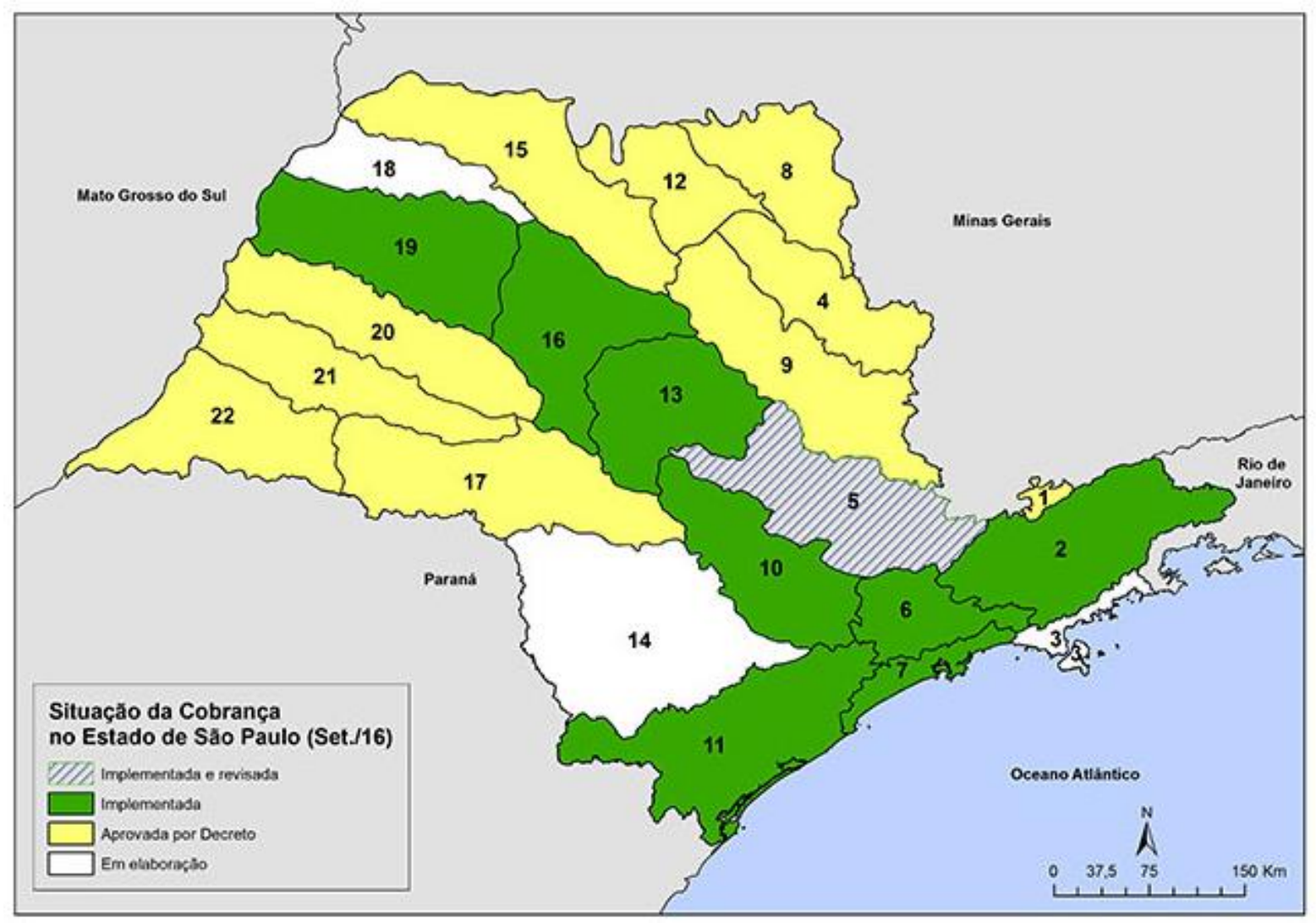

Figura 9. Panorama da Cobrança nos Comitês do Estado de São Paulo Fonte: SIGRH, 2017 


\subsection{Considerações Finais do Capítulo}

Esse Capítulo teve como objetivo principal realizar um levantamento bibliográfico dos trabalhos científicos que tratam do tema Processo Participativo e Gerenciamento de Recursos Hídricos, com enfoque nos instrumentos da Cobrança e do Plano de Bacia.

A partir dos conceitos trazidos por Yassuda (1993), Lanna (1993) e Coimbra (1999), foi possível observar a importância de se adotar um modelo que privilegie a participação social no processo de tomada de decisão, com o intuito de se fazer com que as decisões tomadas no âmbito dos Comitês sejam sempre provenientes de pactos firmados entre os representantes das diversas entidades que o compõem.

A análise do caso brasileiro, mais precisamente no Estado de São Paulo, mostrou a importância dada ao desenvolvimento do Plano de Bacia e do Plano Estadual de Recursos Hídricos, com um horizonte de 4 anos. Os Planos internalizam a figura dos Programas de Duração Continuada (PDCs), que, por sua vez, são utilizados como base para o enquadramento dos projetos a serem financiados com os recursos do FEHIDRO.

Com relação ao FEHIDRO, constatou-se que seus recursos são provenientes majoritariamente da compensação financeira pela utilização dos recursos hídricos e da cobrança pelo uso da água, cada um com seus critérios de arrecadação e distribuição dos valores. A compensação financeira utiliza indicadores pré-estabelecidos para a distribuição dos recursos, com o objetivo de apoiar financeiramente as UGRHIs com piores indicadores socioeconômicos e de criticidade hídrica. Já os valores da cobrança devem ser destinados ao financiamento de projetos na própria Bacia de origem.

A pesquisa sobre esse processo de distribuição dos recursos foi importante por servir de base para a análise dos projetos que foram financiados no Comitê de Bacia Hidrográfica Sorocaba e Médio Tietê. 


\section{CAPÍTULO 2}

\section{CARACTERIZAÇÃO GERAL DA UGRHI 10 SOROCABA E MÉDIO TIETÊ}

Este Capítulo tem por objetivo demonstrar as principais características da Bacia Hidrográfica em estudo, com relação à situação do Uso e Ocupação do Solo, do Saneamento Básico, do Perfil Socioeconômico e do Modelo de Gestão praticado O objetivo principal é analisar as dificuldades/fragilidades encontradas nessa Bacia.

\subsection{Localização da UGRHI}

A Bacia Hidrográfica do Rio Sorocaba e Médio Tietê (definida como UGRHI 10) está localizada no centro-sudeste do Estado de São Paulo (Figura 10). Ela possui 34 municípios com sede em seu território, dos quais 18 estão situados na Bacia do Rio Sorocaba e 16 na Bacia do Médio Tietê. O trecho do Médio Tietê compreende o rio Tietê desde a saída do Reservatório de Pirapora até a Barragem de Barra Bonita (367 km de extensão). Já o rio Sorocaba é o afluente mais importante da margem esquerda do Médio Tietê, drenando uma área de $5.269 \mathrm{~km}^{2}$ e é formado pelos rios Sorocabuçu e Sorocamirim (FREITAS e MARANGON, 1998).

O rio Sorocaba é represado no município de Votorantim, formando o reservatório de Itupararanga (construído pela Light em 1912). Trata-se de um importante manancial para a região, responsável pelo abastecimento de água de grande parte da população dos municípios de Sorocaba, Votorantim, Mairinque, Ibiúna e São Roque. Após esse barramento, o rio atravessa as cidades de Votorantim e Sorocaba, que possuem um importante parque industrial (IPT, 2008).

À montante, a UGRHI recebe águas da bacia do Alto Tietê, e possui a bacia do Tietê-Jacaré a jusante. Também possui como limites as Bacia do PCJ, do Alto e Médio Paranapanema, e do Ribeira de Iguape e Litoral Sul (IPT, 2008).

A UGRHI 10 foi dividida em 6 sub-bacias hidrográficas (Figura 11), três delas drenando para o rio Tietê e três que compõem a bacia do rio Sorocaba. Essa divisão pode ser visualizada no Quadro 4. 


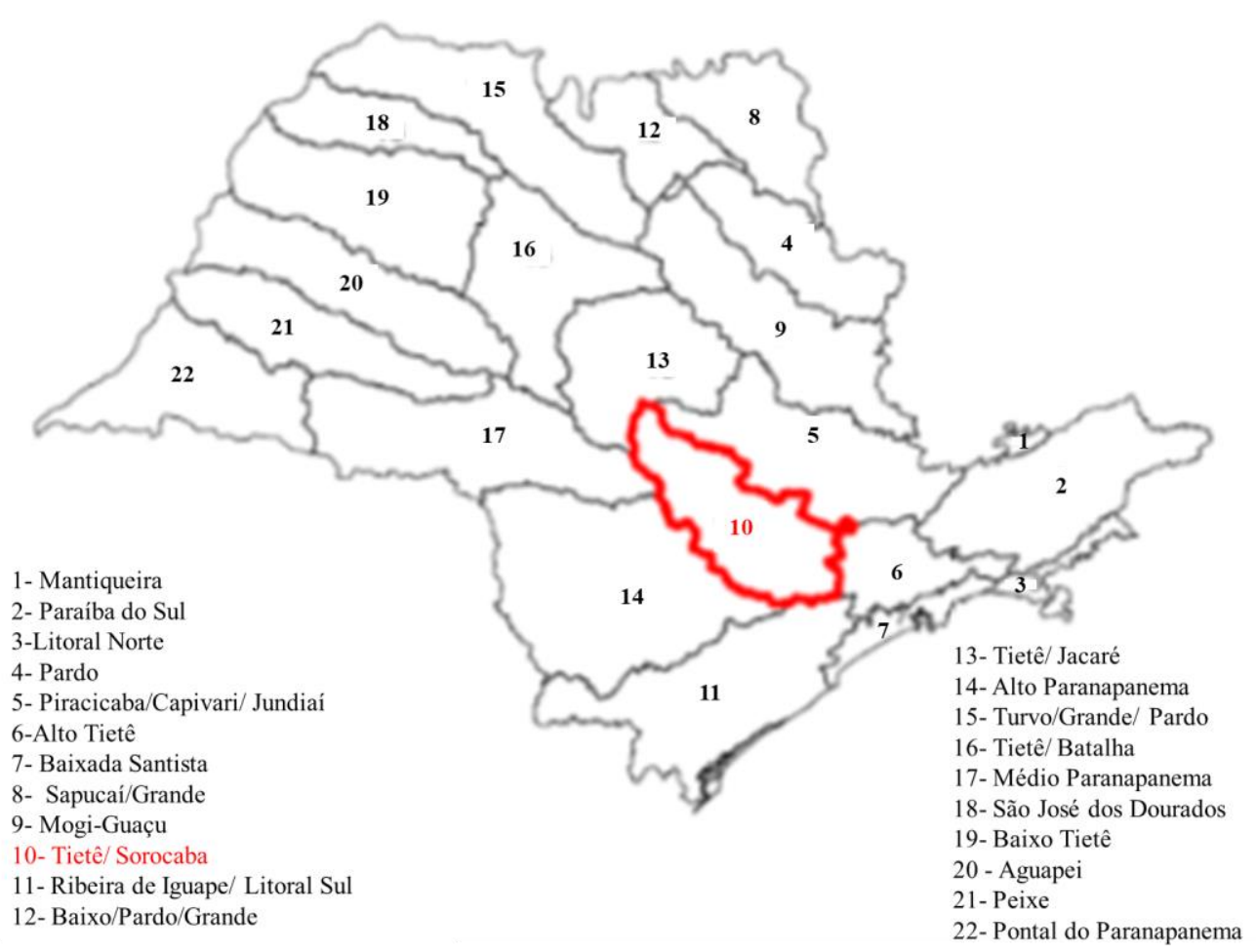

Figura 10. Localização da UGRHI 10 no Estado de São Paulo

Fonte: Relatório de Situação, 2016

Quadro 4. Sub-bacias e municípios que integram a UGRHI

\begin{tabular}{|c|c|c|}
\hline Sub-Bacia & Área $\left(K_{\mathbf{m}^{2}}\right)$ & Municípios \\
\hline $\begin{array}{l}\text { Médio Tietê } \\
\text { Inferior }\end{array}$ & 4.141 & $\begin{array}{l}\text { Anhembi, Barra Bonita, Bofete, Botucatu, Conchas, Laranjal Paulista, } \\
\text { Pereiras. Piracicaba. Saltinho, Tietê. Torre de Pedra }\end{array}$ \\
\hline $\begin{array}{l}\text { Médio Tietê } \\
\text { Médio }\end{array}$ & 1.025 & Boituva, Cerquilho, Porto Feliz, Rafard, Rio das Pedras, Sorocaba, Tietê \\
\hline Baixo Sorocaba & 3.136 & $\begin{array}{l}\text { Alambari, Araçoiaba da Serra, Boituva, Capela do Alto, Cerquilho, Cesário } \\
\text { Lange, Iperó, Itapetininga, Pereiras, Piedade, Pilar do Sul, Salto de Pirapora, } \\
\text { Sarapuí, Tatuí }\end{array}$ \\
\hline $\begin{array}{l}\text { Médio } \\
\text { Sorocaba }\end{array}$ & 1.212 & $\begin{array}{l}\text { Alumínio, Araçoiaba da Serra, Boituva, Capela do Alto, Iperó, Itu, } \\
\text { Mairinque, Porto Feliz, Sorocaba, Votorantim }\end{array}$ \\
\hline $\begin{array}{l}\text { Médio Tietê } \\
\text { Superior }\end{array}$ & 1.388 & $\begin{array}{l}\text { Araçariguama, Cabreúva, Cajamar, Elias Fausto, Indaiatuba, Itapevi, Itu, } \\
\text { Jundiaí, Mairinque, Pirapora do Bom Jesus, Porto Feliz, Salto, Santana de } \\
\text { Parnaiba, São Roque }\end{array}$ \\
\hline Alto Sorocaba & 924 & $\begin{array}{l}\text { Alumínio, Cotia, Ibiúna, Mairinque, Piedade, São Roque, Vargem Grande } \\
\text { Paulista, Votorantim }\end{array}$ \\
\hline Total & 11.828 & \\
\hline
\end{tabular}

Fonte: IPT, 2008 


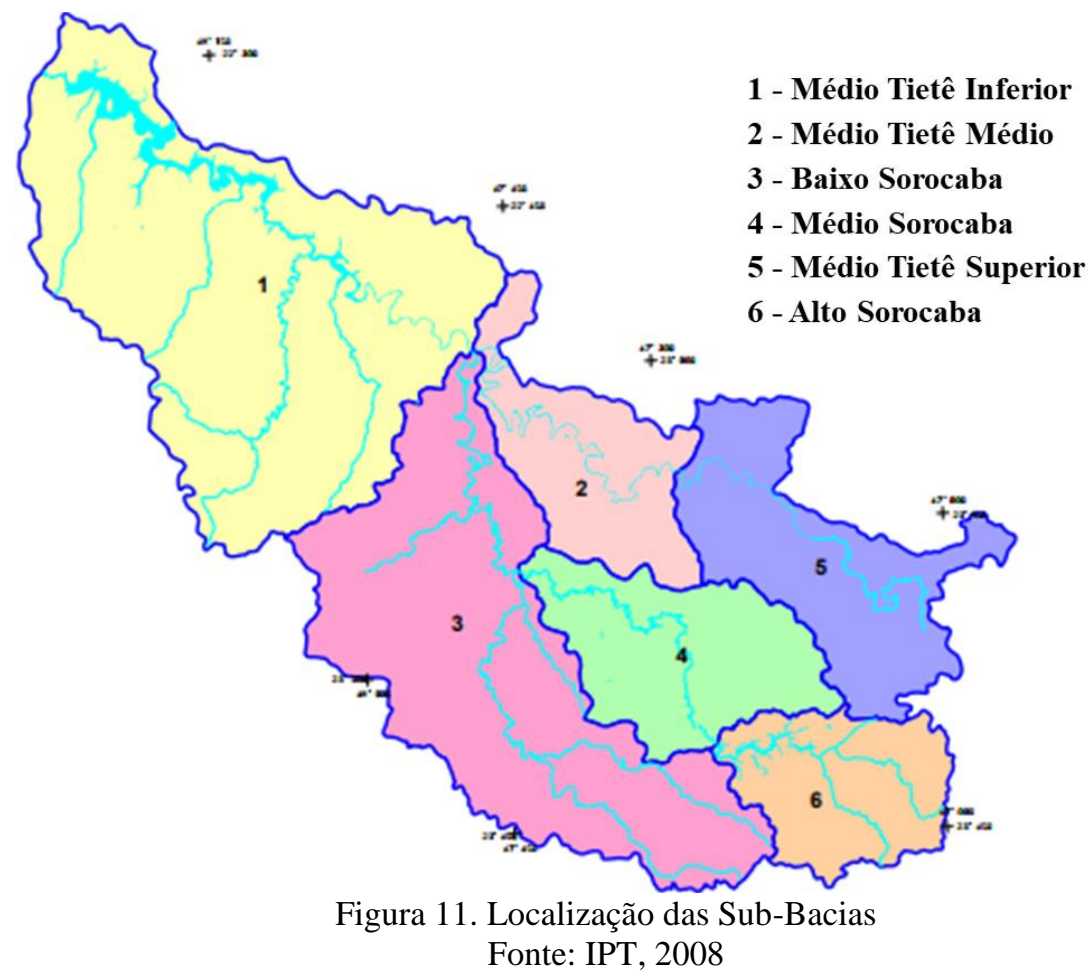

\subsection{Principais Características da UGRHI 10}

De acordo com o Relatório de Situação (2016), a Bacia possui uma população de aproximadamente 1,9 milhões de habitantes, distribuídos em $12 \mathrm{~km}^{2}$. $90 \%$ de sua população é urbana e $10 \%$ é rural. Com relação às atividades econômicas, possui um desenvolvido polo industrial, além de possuir o cultivo de cana de açúcar, de citrus e a pecuária como atividades significativas. Os principais reservatórios são a Represa Itupararanga e Barra Bonita.

Os principais rios são o Sorocaba, o Pirajibu, Sarapuí, o Peixe, Sorocamirim e Tatuí. A vazão média é de $107 \mathrm{~m}$ 3/s e a vazão mínima $\left(\mathrm{Q}_{7,10}\right)$ é de $22 \mathrm{~m} 3 / \mathrm{s}$. Possui um amplo parque industrial nas áreas de telecomunicações e informática, de montagem de veículos automotivos, de refinarias de petróleo, de papel e celulose, entre outras (IPT, 2008).

Quanto às áreas protegidas, possui 3 Unidades de Conservação de Proteção Integral: Estação Ecológica do Barreiro Rico; Parque Natural Municipal da Cachoeira da Marta e Parque Natural Municipal Corredores de Biodiversidade; e 13 Unidades de Conservação de Uso Sustentável: as Áreas de Proteção Ambiental de Cabreúva, de Corumbataí-Botucatu-Tejupá (Perímetro Botucatu), de Ituparanga e do Tietê; Floresta Estadual de Botucatu e Floresta Nacional de Ipanema; e as Reservas Particulares de 
Patrimônio Natural do Centro de Vivência da Natureza, Entre Rios, Floresta Negra, Meandros, Meandros II, Meandros III e Sítio Pithon.

\subsection{Situação da UGRHI 10}

\subsubsection{Uso e Ocupação do Solo}

A sub-bacia do Alto Sorocaba possui os maiores percentuais de cobertura florestal da bacia e altos índices de remanescentes de vegetação original. A principal atividade econômica dessa região é a produção agrícola, sendo considerado um importante centro produtivo de hortifrutigranjeiro para a Região Metropolitana de São Paulo (IPT, 2008).

Já o Médio-Sorocaba apresenta as mais elevadas taxas de urbanização da Bacia, bem como o maior adensamento populacional. Por outro lado, a cobertura vegetal remanescente nessa região possui índices muito baixos, com aproximadamente 4,6\% em Sorocaba e $13 \%$ em Votorantim. O principal cultivo é o milho e o eucalipto (FERNANDES, 2012).

No Baixo Sorocaba a atividade que mais se destaca é a agropecuária. Essa região apresenta poucos remanescentes de cobertura vegetal natural (IPT, 2008).

Analisando a Bacia do Sorocaba como um todo, pode-se perceber que ela apresenta um predomínio de pastagem $(77,45 \%)$, seguido de longe por áreas com culturas agrícolas $(13,72 \%)$. Vale destacar que os remanescentes de cobertura vegetal natural não chegam a 2\% do território total. Essa distribuição das classes de uso e ocupação do solo na Bacia pode ser observada na Tabela 2 (FERNANDES, 2012).

Tabela 2. Distribuição das classes de uso e ocupação do Solo

\begin{tabular}{ccc}
\hline $\begin{array}{c}\text { Classes de Uso e Ocupação } \\
\text { do Solo }\end{array}$ & $\%$ & Área $\left(\mathbf{k m}^{2}\right)$ \\
\hline \hline Pastagem/Campo Antrópico & 77,45 & 4.080 \\
\hline Culturas & 13,72 & 722 \\
\hline Cobertura Vegetal Natural & 1,70 & 89 \\
\hline Reflorestamento & 3,03 & 159 \\
\hline Área Urbana & 4,11 & 216 \\
\hline \hline
\end{tabular}

Fonte: Fernandes, 2012 
Quanto aos processos erosivos, de acordo com o Relatório de Situação (2016), a Bacia possui 80 erosões lineares urbanas cadastradas e 4.228 erosões rurais. Isso se agrava quando constatamos que uma grande parte desse território corresponde à área de ocorrência do Aquífero Guarani, o que implica em maiores vulnerabilidades à contaminação. Sabe-se que essas erosões ocorrem prioritariamente em áreas de alta/muito alta suscetibilidade à erosão. A Tabela 3 nos mostra que aproximadamente $20 \%$ de toda a área da Bacia está enquadrada nessa categoria. Os municípios que apresentam o maior número de ocorrências de erosões são: Conchas (418), Porto Feliz (280), Anhembi (251), Bofete (249), Sarapuí (219) e Tietê (217). Para mitigar esse cenário, seria necessária a efetivação dos planos de controle de erosão rural em toda a UGRHI, porém, devendo-se atentar para os locais mais críticos, ou seja, para os municípios com maior suscetibilidade à erosão.

Esses processos erosivos são agravados à medida que se intensificam os adensamentos urbanos da bacia, aliados à retirada da cobertura vegetal.

A distribuição da suscetibilidade à erosão para a bacia do Sorocaba pode ser observada na Tabela 3 .

Tabela 3. Distribuição da suscetibilidade à erosão na Bacia do Sorocaba

\begin{tabular}{ccc}
\hline \hline Grau de Suscetibilidade & $\mathbf{\%}$ & Área $\left(\mathbf{k m}^{\mathbf{2}}\right)$ \\
\hline \hline Muito Alta & 2,22 & 117 \\
\hline Alta & 18,04 & 951 \\
\hline Média & 6,99 & 369 \\
\hline Muixa & 63,67 & 3.355 \\
\hline Árrea Urbana & 4,96 & 262 \\
\hline \hline
\end{tabular}

Fonte: Fernandes, 2012 


\subsubsection{Saneamento Básico}

O Relatório de Situação da Bacia (2016, Ano Base 2015), nos mostra que, no período analisado de 2010 a 2015, no que tange aos índices de Esgotamento Sanitário, houve uma redução de 7,2\% da carga poluidora remanescente. Essa redução foi resultado de crescentes investimentos na UGRHI que proporcionou uma elevação dos índices de coleta e tratamento dos efluentes domésticos. Para que esses índices continuem a melhorar, o Relatório considera importante que haja o acompanhamento dos prazos das ações propostas nos Planos Municipais de Saneamento, bem como, incentivos a projetos de coleta e tratamento de esgotos nos municípios, além do diagnóstico do saneamento rural, que ainda é incipiente.

Outra preocupação é quanto ao manejo adequado dos resíduos sólidos urbanos. A orientação proposta se dá no sentido de aumentar o atendimento à coleta de resíduos nas áreas críticas. Deve-se auxiliar os municípios mais deficitários para a aplicação da Política Nacional de Resíduos Sólidos. Mais uma alternativa é incentivar o fomento a projetos de reciclagem e de educação ambiental a fim de reduzir a produção de resíduos. Sabe-se que nessa UGHRI há um convênio entre o Consórcio de Estudos, Recuperação e Desenvolvimento da Bacia do Rio Sorocaba e Médio Tietê (CERISO), a Secretaria do Meio Ambiente (SMA) e a Companhia Ambiental do Estado de São Paulo (CETESB) com o intuito de desenvolver os planos municipais de resíduos sólidos, processo que deverá resultar em um plano regional de resíduos sólidos.

Quanto ao acompanhamento dos índices de qualidade da água, o Relatório (2016) primeiramente sugere que haja uma ampliação no monitoramento quali-quantitativo na Bacia, principalmente em rios tributários que ainda são pouco monitorados. E para os locais onde já há monitoramento, porém, esses índices possuem um valor reduzido, a sugestão trazida é implantar projetos de restauração de Área de Preservação Permanente (APP) em áreas rurais e projetos de controle de erosão rural e manejo adequado do solo e da produção agrícola, com o objetivo de tentar diminuir a incidência de carga difusa nos corpos hídricos.

\subsubsection{Perfil Socioeconômico}

No que tange à análise da dinâmica socioeconômica, o Relatório (2016) apresenta como um dos parâmetros o Índice Paulista de Responsabilidade Social (IPRS). De acordo 
com a Fundação Seade (2015), esse índice objetiva preservar as três dimensões componentes do IDH - renda, escolaridade e longevidade, sendo assim composto por quatro conjuntos de indicadores: três setoriais, que mensuram as condições atuais do município em termos de renda, escolaridade e longevidade; e uma tipologia constituída de cinco grupos, denominada grupos do IPRS, resumindo a situação municipal segundo os três eixos considerados, de forma multidimensional. A Tabela 4 mostra essas variáveis consideradas em cada uma das dimensões do IPRS e a estrutura de ponderação utilizada.

Tabela 4. As dimensões adotadas e suas respectivas contribuições para o indicador

\begin{tabular}{|c|c|c|}
\hline Dimensões & Componentes & Contribuição para o indicador \\
\hline \multirow{4}{*}{$\begin{array}{l}\text { Riqueza } \\
\text { Municipal }\end{array}$} & Consumo residencial de energia elétrica, por ligação & $25 \%$ \\
\hline & $\begin{array}{l}\text { Consumo de energia elétrica na agricultura, no comércio e } \\
\text { nos serviços, por ligação }\end{array}$ & $25 \%$ \\
\hline & $\begin{array}{l}\text { Remuneração média dos empregados com carteira assinada } \\
\text { e do setor público }\end{array}$ & $25 \%$ \\
\hline & Valor adicionado fiscal per capita & $25 \%$ \\
\hline \multirow{4}{*}{ Longevidade } & Taxa de mortalidade perinatal & $30 \%$ \\
\hline & Taxa de mortalidade infantil & $30 \%$ \\
\hline & Taxa de mortalidade de pessoas de 15 a 39 anos & $20 \%$ \\
\hline & Taxa de mortalidade de pessoas de 60 a 69 anos & $20 \%$ \\
\hline \multirow{4}{*}{ Escolaridade } & Taxa de atendimento escolar na faixa de 4 a 5 anos & $19 \%$ \\
\hline & $\begin{array}{l}\text { Média da proporção de alunos do } 5^{\circ} \text { ano do ensino } \\
\text { fundamental da rede pública que atingiram pelo menos o nivel }\end{array}$ & $31 \%$ \\
\hline & $\begin{array}{l}\text { Média da proporção de alunos do } 9^{\circ} \text { ano do ensino } \\
\text { fundamental da rede pública que atingiram pelo menos o nivel }\end{array}$ & $31 \%$ \\
\hline & Taxa de distorção idade-série no ensino médio & $19 \%$ \\
\hline
\end{tabular}

Fonte: Fundação Seade, 2015

As três dimensões combinadas proporcionam uma tipologia onde é possível classificar todos os municípios do Estado de São Paulo em cinco grupos com características similares de riqueza municipal, longevidade e escolaridade. O Quadro 5 apresenta as categorias referentes a cada um desses grupos (FUNDAÇÃO SEADE, 2015). 
Quadro 5. Critérios adotados para a distribuição dos municípios e grupos

\begin{tabular}{|c|c|}
\hline Grupos & Categorias \\
\hline \multirow{4}{*}{ Grupo 1} & Alta riqueza, alta longevidade e alta escolaridade \\
\hline & Alta riqueza, alta longevidade e média escolaridade \\
\hline & Alta riqueza, média longevidade e alta escolaridade \\
\hline & Alta riqueza, média longevidade e média escolaridade \\
\hline \multirow{5}{*}{ Grupo 2} & Alta riqueza, alta longevidade e baixa escolaridade \\
\hline & Alta riqueza, média longevidade e baixa escolaridade \\
\hline & Alta riqueza, baixa longevidade e alta escolaridade \\
\hline & Alta riqueza, baixa longevidade e média escolaridade \\
\hline & Alta riqueza, baixa longevidade e baixa escolaridade \\
\hline \multirow{4}{*}{ Grupo 3} & Baixa riqueza, alta longevidade e alta escolaridade \\
\hline & Baixa riqueza, alta longevidade e média escolaridade \\
\hline & Baixa riqueza, média longevidade e alta escolaridade \\
\hline & Baixa riqueza, média longevidade e média escolaridade \\
\hline \multirow{4}{*}{ Grupo 4} & Baixa riqueza, alta longevidade e baixa escolaridade \\
\hline & Baixa riqueza, média longevidade e baixa escolaridade \\
\hline & Baixa riqueza, baixa longevidade e alta escolaridade \\
\hline & Baixa riqueza, baixa longevidade e média escolaridade \\
\hline Grupo 5 & Baixa riqueza, baixa longevidade e baixa escolaridade \\
\hline
\end{tabular}

Fonte: Fundação Seade, 2015

Tomando como referência os municípios da UGRHI estudada, observamos que, no período analisado, houve uma redução significativa de municípios que estavam enquadrados no Grupo 5 do IPRS, ao mesmo tempo em que aumentou o número dos enquadrados no Grupo 3. Essa variação nos leva a crer que houve uma melhora nos indicadores sociais (passando de insatisfatórios para bons). Ainda, de acordo com a Figura 12, há dois municípios enquadrados no Grupo 5: Alambarí e Sarapuí. Ambos na Bacia do Baixo Sorocaba. O destaque vale para os municípios classificados no Grupo 1, 
que são: Boituva, Porto Feliz, Sorocaba, Mairinque, Itu e Vargem Grande Paulista. Esse grupo corresponde a bons indicadores sociais e com riqueza alta. Essa distribuição pode ser visualizada na Figura 12 (RELATÓRIO DE SITUAÇÃO, 2016).

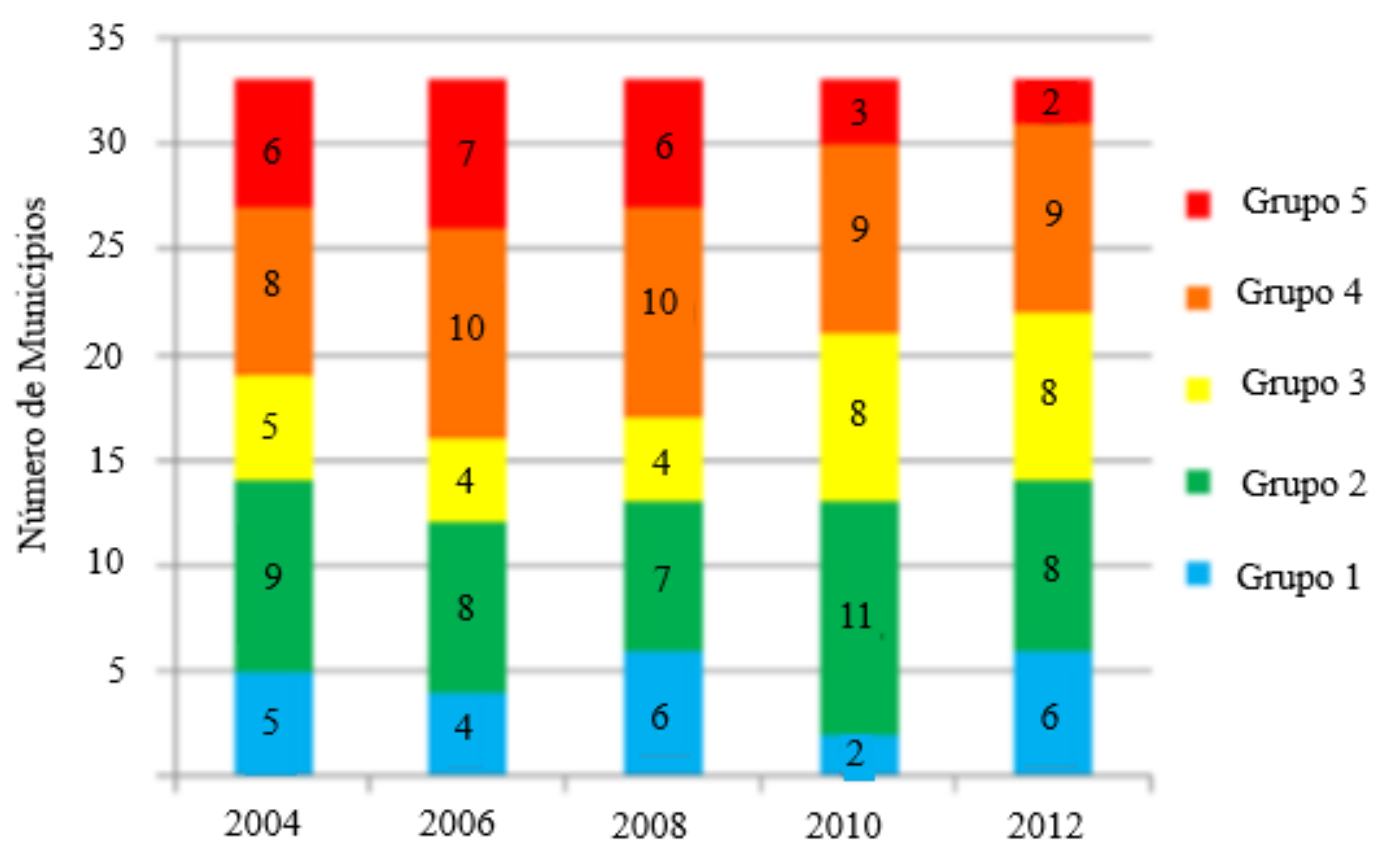

Figura 12. Distribuição dos municípios da UGRHI 10 em grupos de acordo com o IPRS Fonte: Elaborado a partir do Relatório de Situação, 2016

\subsection{Gestão dos Recursos Hídricos na Bacia}

A gestão dos recursos hídricos na UGRHI 10 é realizada pelo Comitê da Bacia Hidrográfica dos rios Sorocaba e Médio Tietê (BERNAL, 2012).

Em 1993 foi formado um Núcleo de Estudos Ambientais, com o objetivo de realizar um diagnóstico da situação da bacia. Os resultados mostraram uma grande carência de dados sobre a região, surgindo assim uma oportunidade para a criação de um Comitê. A partir dos esforços das organizações não-governamentais com sede na Bacia, dos representantes dos municípios e dos órgãos estatais e Secretarias de Estado, foi criado então, a partir de uma reunião no município de Itu, em 1995, o CBH-SMT (FREITAS e MARANGON, 1998).

As maiores preocupações ficaram em torno da poluição das águas do Tietê e do reservatório de Itupararanga, principal manancial da bacia do Sorocaba.

Atualmente o comitê é constituído por 34 municípios, órgãos do estado e representante da sociedade civil organizada. O comitê também possui uma Fundação 
Agência de bacias dos rios Sorocaba e Médio Tietê, criado em 2003 com o objetivo de prestar apoio técnico, administrativo e financeiro (SIGRH, 2017).

O Comitê está estruturado da seguinte maneira (assegurada a paridade de votos entre estado, municípios e sociedade civil:

I. 17 representantes designados pelo Estado, titulares e respectivos suplentes, das entidades representadas;

II. Municípios que compreendam a região da Bacia, com direito a 17 votos. A escolha dos representantes ocorre por acordo entre os municípios membros, que se alternam na titularidade e suplência;

III. 17 representantes titulares e respectivos suplentes da sociedade civil eleitos pelas entidades cadastradas em cada uma das categorias elencadas a seguir:

a) Universidades, institutos de ensino superior, entidades de pesquisa e desenvolvimento tecnológico;

b) Usuários das águas, representados por entidades associativas;

c) Associações especializadas em recursos hídricos, entidade de classe, associações comunitárias e demais associações governamentais;

d) Entidades ambientalistas.

A duração dos mandatos dos integrantes do Comitê é de 02 (dois) anos, e os prefeitos municipais somente terão direito à representação durante o período de seus mandatos, sendo a função de representante vinculada ao cargo.

Para o tratamento das questões específicas, o Comitê criou as seguintes Câmaras Técnicas: Planejamento e Gestão dos Recurso Hídricos (CTPLAGRHI); Proteção das Águas (CTPA); Saneamento (CTSAN); Eventos e Educação Ambiental (CTEEA); Cobrança (CTCOB); e Planejamento Florestal (CTPLANFLOR).

Já o seu Plano de Bacia foi aprovado em 2008 e elaborado pelo Instituto de Pesquisas Tecnológicas (IPT). Possui um horizonte de 2008 a 2019, com metas de curto, médio e longo prazo. Ao todo, foram estabelecidas quatorze metas, as quais foram aprovadas pelo CBH-SMT na Assembleia ocorrida no dia 09 de fevereiro de 2007, em Cerquilho. Tratam-se das seguintes metas: alcançar os $100 \%$ na coleta e no tratamento do esgoto urbano; implantar ou adequar os sistemas de destinação de resíduos sólidos domiciliares; atingir a universalização na distribuição e no tratamento de água; elaborar programas de combate a perdas e de prevenção às erosões urbanas de médio e grande 
porte; elaborar estudos para delimitação de áreas de restrição e controle do uso das águas subterrâneas; reduzir em 30\% o déficit atual de vegetação em Áreas de Preservação Permanente e em $10 \%$ o déficit atual de vegetação de Reserva Legal; recompor e operar a rede de monitoramento hidrológico; manter as bases técnicas necessárias para o gerenciamento de recursos hídricos e manter atualizados os mecanismos de capacitação e educação ambiental para todos os segmentos do Comitê (IPT, 2008). A elaboração do Plano contou com a participação de aproximadamente 120 entidades e com mais de 600 pessoas envolvidas. Todas as contribuições foram consolidadas e uma audiência pública e foram contempladas no Plano de Bacia.

\subsection{1 Índice de Renovação do Segmento Sociedade Civil}

O segmento Sociedade Civil é o que possui a maior quantidade de entidades diferentes que já foram representantes, são no total 107 entidades, contra 19 do Estado e 34 dos municípios. Dentre os 34 municípios, a alternância ocorre por acordo entre eles, alternando a titularidade e a suplência, porém, todos possuem vagas garantidas. Já os órgãos representantes do segmento Estado não possuem renovação, e alguns deles ainda ocupam as vagas de titular e de suplente ao mesmo tempo.

Como visto, o segmento sociedade civil possui uma grande heterogeneidade entre as entidades representantes, uma vez que é composto por quatro grandes grupos de interesses muito distintos (entidades ambientalistas, usuários das águas representados por entidades associativas, associações especializadas em recursos hídricos e institutos de ensino). Pode-se observar, a partir das Tabelas 5 a 8 , que as instituições às quais os representantes fazem parte e que pertencem a este segmento possuem uma alta rotatividade nos mandatos no Comitê. Têm-se que, em média, apenas 56\% dos indivíduos se mantêm de uma gestão para outra. Esse valor é referente à substituição dessas instituições ao longo das gestões.

A compilação dessas Tabelas, contendo as entidades da Sociedade Civil em todas as Gestões do CBH-SMT, é dada da seguinte forma: Associações Especializadas em RHs aparecem com um índice de permanência na casa dos 44\%, seguido pelas Entidades Ambientalistas, com 53\%. Os Usuários das Águas estão em segundo lugar com 60\% e as entidades que permanecem por mais tempo entre as gestões são as ligadas às Universidades e Institutos de Ensino, com 67\%. A média geral dessas instituições está por volta dos 56\% (Tabela 9). 
Tabela 5. Permanência das Entidades da Sociedade Civil ao longo das Gestões de 1995 a 2001*

\begin{tabular}{|c|c|c|c|}
\hline & 1995-1997 & 1997-1999 & 1999-2001 \\
\hline $\begin{array}{l}\text { Entidades } \\
\text { Ambientalistas }\end{array}$ & $\begin{array}{c}\text { ICATU } \\
\text { ICATU } \\
\text { Núcleo Ecológico Morro de Ipanema } \\
\text { Ass.Juventude Ecológica de São Roque } \\
\text { ALERTA Tatuí } \\
\text { ALERTA Tatuí } \\
\text { AESFA } \\
\text { AESFA }\end{array}$ & $\begin{array}{c}\text { Fundação SOS Mata Atlântica } \\
\text { Associação Juventude Ecológica de São Roque } \\
\text { Tietê - PróTietê } \\
\text { ALERTA Tatuí } \\
\text { Associação Ecológica Icatu } \\
\text { Associação de Defesa da Estrada Parque } \\
\text { Associação Ecológica São Francisco de Assis } \\
\text { Núcleo Ecológico Morro de Ipanema }\end{array}$ & $\begin{array}{c}\text { ALERTA Tatuí } \\
\text { Fundação Terra de Sorocaba } \\
\text { Fundação SOS Mata Atlântica } \\
\text { Associação Ecológica São Francisco de Assis } \\
\text { Tietê Pró Tiete } \\
\text { Associação Juventude Ecológica de São Roque } \\
\text { Associação Ecológica Icatu } \\
\text { Associação Estrada Parque de ltu } \\
\end{array}$ \\
\hline $\begin{array}{c}\text { Índice de } \\
\text { Permanência }\end{array}$ & & $50 \%$ & $87,5 \%$ \\
\hline $\begin{array}{l}\text { Usuários das } \\
\text { águas, } \\
\text { representados } \\
\text { por Entidades } \\
\text { Associativas }\end{array}$ & $\begin{array}{l}\text { Ass. Comercial, Industrial e Agrícola de Ibiuna } \\
\text { Ass. Comercial, Industrial e Agrícola de Salto } \\
\text { Ass. Comercial, Ind. e Agrícola de Sao Roque } \\
\text { Ass. das Ind. de São Roque, Araçariguama } \\
\text { Sindicato Rural Patronal de São Roque } \\
\text { Ass. Comercial, Industrial e Agrícola de boituva } \\
\text { Associação das Indústrias de Salto } \\
\text { Sindicato dos Trabalhadores Rurais de Ibiúna }\end{array}$ & $\begin{array}{l}\text { Ass. Comercial, Industrial e Agrícola de Salto } \\
\text { Associação das Indústrias de Salto } \\
\text { Sindicato Rural Patronal de São Roque } \\
\text { Sindicato Rural de Conchas } \\
\text { CIESP } \\
\text { Ass. das Ind. de São Roque, Araçariguama } \\
\text { Sindicato dos Trabalhadores Rurais de Ibiúna } \\
\text { Sindicato dos Trabalhadores Rurais de São Roque }\end{array}$ & $\begin{array}{c}\text { Associação das Indústrias de Salto } \\
\text { Associação das Indústrias de Salto } \\
\text { Sindicato Rural Patronal de São Roque } \\
\text { Sindicato Rural de Piedade } \\
\text { CIESP Botucatu } \\
\text { CIESP Botucatu } \\
\text { CIESP Sorocaba } \\
\text { CIESP Sorocaba } \\
\end{array}$ \\
\hline $\begin{array}{l}\text { Índice de } \\
\text { Permanência }\end{array}$ & & $62,5 \%$ & $62,5 \%$ \\
\hline $\begin{array}{l}\text { Associações } \\
\text { especializadas } \\
\text { em RHs, de } \\
\text { entidades de } \\
\text { classe e } \\
\text { associações } \\
\text { comunitárias }\end{array}$ & $\begin{array}{l}\text { Ass. dos Eng. }{ }^{\circ} \text { e Arq. de São Roque, Mairinque, } \\
\text { Ibiúna, Araçariguama e Alumínio } \\
\text { Ass Prot. ao Patri. Ecol. Historico e Cultural } \\
\text { Ass. dos Engenheiros e Arquitetos de Sorocaba } \\
\text { Associação Regional dos Jornalistas Profissionais } \\
\text { Instituto de Arquitetos do Brasil - IAB } \\
\text { Associação Sorocabana de Imprensa } \\
\text { Ass. De Ensino de Botucatu } \\
\text { Ass. De Ensino de Botucatu }\end{array}$ & $\begin{array}{l}\text { Ass. dos Engenheiros e Arquitetos de Sorocaba } \\
\text { Instituto de Arquitetos do Brasil } \\
\text { Ass. dos Eng. e Arq. de São Roque, Mairinque } \\
\text { Associação dos Engenheiros e Arquitetos de Itu } \\
\text { Cons. Reg. de Eng. Arquitetura e Agronomia } \\
\text { Ass. Comercial, Industrial e Agrícola de Ibiúna } \\
\text { Ass. Comercial, Industrial e Agrícola de Ibiúna } \\
\text { Associação Regional dos Jornalistas Profissionais }\end{array}$ & $\begin{array}{l}\text { Ass. dos Eng. e Arquitetos de Sorocaba } \\
\text { Sindicato dos Engenheiros no Estado de São Paulo } \\
\text { Ass. dos Eng. e Arq. de São Roque, Mairinque } \\
\text { Instituto de Desenvolvimento Regional de Salto } \\
\text { Inst. de Arquitetos do Brasil - Núcleo Sorocaba } \\
\text { SOS Cuestas de Botucatu } \\
\text { Associação Sorocabana de Imprensa } \\
\text { Assoc. Paul. de Emp. de Consul. em Saneamento }\end{array}$ \\
\hline $\begin{array}{c}\text { Índice de } \\
\text { Permanência }\end{array}$ & & $50 \%$ & $37,5 \%$ \\
\hline $\begin{array}{l}\text { Universidades, } \\
\text { Institutos de } \\
\text { Ensino }\end{array}$ & $\begin{array}{c}\text { Puc SOROCABA } \\
\text { Puc SOROCABA } \\
\text { ETEC Fernando Prestes } \\
\text { INEVAT } \\
\text { NEAS - UNISO } \\
\text { Setor de Asse. e Orientação Jurídica de Salto } \\
\text { Faculdade de Tecnologia de Sorocaba - FATEC } \\
\text { Inst. Aruandista de Pesquisa e Desenvolvimento } \\
\text { NEAS - UNISO } \\
\text { UNESP Botucatu } \\
\end{array}$ & $\begin{array}{c}\text { UNISO } \\
\text { UNISO } \\
\text { Pontifícia Universidade Católica - PUC } \\
\text { Pontifícia Universidade Católica - PUC } \\
\text { Faculdade de Tecnologia de Sorocaba - FATEC } \\
\text { Faculdade de Engenharia de Sorocaba - FACENS } \\
\text { Instituto de Estudos do Vale do Tietê - INEVAT } \\
\text { Setor de Assessoria e Orientação Jurídica de Salto } \\
\text { Instituto de Biociências - UNESP - Botucatu } \\
\text { Instituto Sócio Ambiental de Sorocaba - ISAS }\end{array}$ & $\begin{array}{c}\text { UNISO } \\
\text { UNISO } \\
\text { PUC Sorocaba } \\
\text { PUC Sorocaba } \\
\text { Faculdade de Direito de ltu } \\
\text { CREA Sorocaba } \\
\text { UNESP Botucatu } \\
\text { UNESP Botucatu } \\
\text { Instituto de Estudos do Vale do Tietê - INEVAT } \\
\text { Setor de Assessoria e Orientação Jurídica de Salto }\end{array}$ \\
\hline $\begin{array}{c}\text { Índice de } \\
\text { Permanência }\end{array}$ & & $80 \%$ & $80 \%$ \\
\hline
\end{tabular}

*Em azul: Entidades da Sociedade Civil que permaneceram de uma Gestão para outra.

Fonte: Adaptado de Carvalho. 2011 
Tabela 6. Permanência das Entidades da Sociedade Civil ao longo das Gestões de 2001 a 2007*

\begin{tabular}{|c|c|c|c|}
\hline & 2001-2003 & 2003-2005 & 2005-2007 \\
\hline $\begin{array}{c}\text { Entidades } \\
\text { Ambientalistas }\end{array}$ & $\begin{array}{c}\text { Fundação SOS Mata Atlântica } \\
\text { Associação Suçuarana } \\
\text { ALERTA Tatuí } \\
\text { Associação Ecológica Icatu } \\
\text { Tietê Pró Tietê } \\
\text { Associação Japi } \\
\text { Iss. Hol. de Participação Com. Ecol. Núcleo da Terr } \\
\text { Associação Terra de Proteção Ambiental }\end{array}$ & $\begin{array}{c}\text { Fundação SOS Mata Atlântica } \\
\text { ALERTA Tatuí } \\
\text { ıssociação Juventude Ecológica de São Roque - AJI } \\
\text { Associação Sussuarana } \\
\text { Associação Ecológica Icatu } \\
\text { Tietê Pró Tietê } \\
\text { Associação Japi - Cabreúva } \\
\text { Tsi: } \quad \text { Associação Terra de Proteção Ambiental }\end{array}$ & $\begin{array}{l}\text { Org. da Soc. Civil de Int. Público SOS Itupararanga } \\
\text { Entidade Ambientalista Amainan Brasil } \\
\text { Fundação SOS Mata Atlântica } \\
\text { Associação Ecológica Icatu } \\
\text { Iss. Hol. de Participação Com. - "NÚCLEO DA TERRA } \\
\text { ALERTA Tatuí } \\
\text { Associação Japi - Cabreúva } \\
\text { Associação Juventude Ecológica de São Roque } \\
\text { Núcleo Ecológico Morro Ipanema } \\
\text { ONG Itupararanga }\end{array}$ \\
\hline $\begin{array}{c}\text { Índice de } \\
\text { Permanência }\end{array}$ & $50,0 \%$ & $50 \%$ & $62,5 \%$ \\
\hline $\begin{array}{l}\text { Usuários das } \\
\text { águas, } \\
\text { representados } \\
\text { por Entidades } \\
\text { Associativas }\end{array}$ & $\begin{array}{c}\text { CIESP Sorocaba } \\
\text { Sindicato Rural de Piedade } \\
\text { Associação dos Agricultores de Cabreúva } \\
\text { Sindicato Rural Patronal de Cerquilho } \\
\text { Assoc. dos Usuários de Rec. Hídricos de Tatuí } \\
\text { Sindicato Rural Patronal de São Roque } \\
\text { Associação das Indústrias de Salto } \\
\text { UNESP Botucatu - Faculdade de Agronomia }\end{array}$ & $\begin{array}{l}\text { União Agroindústria Canavieira de São Paulo } \\
\text { Sindicato Rural Patronal de Cerquilho } \\
\text { Centro das Indústrias do Estado de São Paulo } \\
\text { Associação Sorocaba das Indústrias - ASSINDS } \\
\text { Sindicato Rural Patronal de São Roque } \\
\text { Sindicato Rural de Tatuí } \\
\text { Ass. dos Usuários de Recursos Hídricos de Tatuí } \\
\text { Associação das Indústrias de Salto } \\
\text { Sindicato Rural de Piedade } \\
\text { Sindicato Rural de Piedade }\end{array}$ & $\begin{array}{c}\text { Sindicato Rural de Piedade } \\
\text { Sindicato Rural de Porto Feliz } \\
\text { Ass. dos Usuários de Recursos Hídricos de Tatuí } \\
\text { ABCON } \\
\text { CIESP SOROCABA } \\
\text { Associação Sorocaba das Indústrias - ASSINDS } \\
\text { Associação das Indústrias de Salto } \\
\text { Sindicato Rural Patronal de São Roque }\end{array}$ \\
\hline $\begin{array}{c}\text { Índice de } \\
\text { Permanência }\end{array}$ & $50 \%$ & $75 \%$ & $60 \%$ \\
\hline $\begin{array}{l}\text { Associações } \\
\text { especializadas } \\
\text { em RHs, de } \\
\text { entidades de } \\
\text { classe e } \\
\text { associações } \\
\text { comunitárias }\end{array}$ & $\begin{array}{l}\text { Sindicato dos Pescadores Artesanais de São Paulo } \\
\text { Instituto de Desenvolvimento Regional de Salto } \\
\text { Instituto VITA } \\
\text { Associação dos Engenheiros e Arquitetos de Itu } \\
\text { tss. Paulista de Emp. de Consultoria em Saneament } \\
\text { Sindicato dos Eng. do Est. de São Paulo - Botucatu } \\
\text { Instituto de Arquitetos do Brasil - IAB } \\
\text { Associação Ecológica São Francisco de Assis }\end{array}$ & $\begin{array}{l}\text { tss. Paulista de Emp. de Consultoria em Saneamentt } \\
\text { Ordem dos Advogados do Brasil - 25a Subsecção } \\
\text { da OAB de Botucatu } \\
\text { Assoc. Eng. Arquit. São Roque, Mairinque, Ibiúna, } \\
\text { Araçariguama e Alumínio } \\
\text { Associaçãa dos Engenheiros e Arquitetos - Sorocab } c \\
\text { SINTAEMA } \\
\text { Associação Ecológica São Francisco de Assis } \\
\text { REA - Conselho Regional de Eng. Arq. E Agronom } \\
\text { Instituto dos Arquitetos do Brasil - IAB - Núcleo }\end{array}$ & $\begin{array}{c}\text { SINTAEMA } \\
\text { Ass. Missionária dos Amigos e Servo do Senhor } \\
\text { CREA - Conselho Regional de Eng. Arq. E Agronomia } \\
\text { Centro de Estudos e Apoio ao Desenvolvimento } \\
\text { Emprego e Cidadania } \\
\text { OAB - } 24^{\mathrm{a}} \text { Subseç̧ão da OAB de Sorocaba } \\
\text { OAB - } 144^{2} \text { Subsecção da OAB Ibiúna/SP } \\
\text { Associação Sorocabana de Imprensa - ASI } \\
\text { Associação Comercial e Empresarial de Mairinque }\end{array}$ \\
\hline $\begin{array}{c}\text { Índice de } \\
\text { Permanência }\end{array}$ & $50 \%$ & $37,50 \%$ & $25 \%$ \\
\hline $\begin{array}{l}\text { Universidades, } \\
\text { Institutos de } \\
\text { Ensino }\end{array}$ & $\begin{array}{l}\text { Pontifícia Universidade Católica - PUC Sorocaba } \\
\text { UNESP Botucatu - Instituto de Biociências } \\
\text { UNISO } \\
\text { CREA Sorocaba } \\
\text { Inst. Histórico Geo. e Genealógico de Sorocaba } \\
\text { Faculdade de Direito de ltu - OSAC } \\
\text { Instituto de Estudos do Vale do Tietê - INEVAT } \\
\text { UNIFAC - Botucatu }\end{array}$ & $\begin{array}{l}\text { Universidade de Sorocaba - UNISO } \\
\text { Pontifícia Universidade Católica - PUC Sorocaba } \\
\text { UNESP Botucatu } \\
\text { Faculdade de Ciências Agronômicas - UNESP } \\
\text { Instituto de Estudos do Vale do Tietê - INEVAT } \\
\text { Instituto Vita } \\
\text { Faculdade de Direito de ltu - OSAC } \\
\text { Inst. Aruandista de Pesquisa e Desenvolvimento }\end{array}$ & $\begin{array}{c}\text { Faculdade de Direito de Itu } \\
\text { Faculdade Evolução } \\
\text { Faculdade de Ciências Agronômicas - UNESP } \\
\text { Grupo Org. Trab. Pró-Amb. de Salto de Pirapora } \\
\text { Universidade de Sorocaba - UNISO } \\
\text { Inst. Aruandista de Pesquisa e Desenvolvimento } \\
\text { Instituto de Estutos do Vale do Tietê - INEVAT } \\
\text { Grupo de Estudos e Pesquisas de Eco. Aquáticos }\end{array}$ \\
\hline $\begin{array}{l}\text { Índice de } \\
\text { Permanência }\end{array}$ & $60 \%$ & $75 \%$ & $63 \%$ \\
\hline
\end{tabular}

*Em azul: Entidades da Sociedade Civil que permaneceram de uma Gestão para outra.

Fonte: Adaptado de Carvalho. 2011 
Tabela 7. Permanência das Entidades da Sociedade Civil ao longo das Gestões de 2007 a $2013 *$

\begin{tabular}{|c|c|c|c|}
\hline & 2007-2009 & 2009-2011 & 2011-2013 \\
\hline $\begin{array}{c}\text { Entidades } \\
\text { Ambientalistas }\end{array}$ & $\begin{array}{c}\text { Associação Ecológica São Francisco de Assis } \\
\text { Organização Ambientalista Amainan Brasil } \\
\text { Ong Itupararanga } \\
\text { Ass. Hol. - “NÚCLEO DA TERRA } \\
\text { Associação Japi } \\
\text { 5 Elementos Instituto de Educ. e Pesquisa Amb. } \\
\text { SOS Cuesta } \\
\text { Grupo Org. Trab. Pró Ambiente }\end{array}$ & $\begin{array}{c}\text { SOS Itupararanga } \\
\text { Associação Ecológica Icatu } \\
\text { Ass. Hol. - "NÚCLEO DA TERRA } \\
\text { Ação e Cidadania - Iperó } \\
\text { Organização Ambientalista Amainam Brasil } \\
\text { Associação Ecológica S. Francisco de Assis } \\
\text { Instituto Plena Cidadania - Plenu } \\
\text { Associação dos Gestores pela Unidade Ambiental }\end{array}$ & $\begin{array}{c}\text { SOS CUESTA DE BOTUCATU } \\
\text { Grupo de Trabalho Ambiental Geriva } \\
5 \text { Elementos Instituto de Educ. e Pesquisa Amb. } \\
\text { Associação Ecológica São Francisco de Assis } \\
\text { Inst. de Projetos e Pesquisas Sócio Ambientais } \\
\text { Org.da Soc. Civil de Int. Púb. SOS Itupararanga } \\
\text { Organização Ambientalista Amainan Brasil } \\
\text { S O S MATA ATLÂNTICA } \\
\text { Instituto Refloresta } \\
\text { ALERTA }\end{array}$ \\
\hline $\begin{array}{c}\text { Índice de } \\
\text { Permanência }\end{array}$ & $40 \%$ & $50 \%$ & $38 \%$ \\
\hline $\begin{array}{l}\text { Usuários das } \\
\text { águas, } \\
\text { representados } \\
\text { por Entidades } \\
\text { Associativas }\end{array}$ & $\begin{array}{c}\text { Sindicato Rural de Piedade } \\
\text { Sindicato Rural de Porto Feliz } \\
\text { ÚNICA } \\
\text { Ass. dos Usuários de RH de Tatuí } \\
\text { CIESP } \\
\text { FIESP } \\
\text { Sind. das Ind. de Extr. de Areia } \\
\text { Ass. Missionária dos Amigos e Servos do Senhor } \\
\text { Sindicato Rural de São Roque } \\
\text { Associaçãoo dos Engenheiros da CETESB }\end{array}$ & $\begin{array}{c}\text { CIESP - Sorocaba } \\
\text { FIESP } \\
\text { União Agroindústria Canavieira de São Paulo } \\
\text { CIESP - Botucatu } \\
\text { Sindicato Rural de Piedade } \\
\text { Sindicato Rural de Porto Feliz } \\
\text { Sind. das Ind. de Extr. de Areia } \\
\text { Ass. dos Usuários de Recursos Hídricos de Tatuí } \\
\text { Sintaema } \\
\text { Sintaema }\end{array}$ & $\begin{array}{l}\text { União Agroindústria Canavieira de São Paulo } \\
\text { CIESP - Botucatu } \\
\text { Assoc. Conc. Priv. de de Água e Esgoto } \\
\text { Consórcio Intermunicipal do Ribeirão Piraí } \\
\text { CIESP - Sorocaba } \\
\text { FIESP } \\
\text { Ass. Miss. dos Amigos e Servos do Senhor } \\
\text { Ass. Miss. dos Amigos e Servos do Senhor }\end{array}$ \\
\hline $\begin{array}{c}\text { Índice de } \\
\text { Permanência }\end{array}$ & $63 \%$ & $80 \%$ & $40 \%$ \\
\hline $\begin{array}{l}\text { Associações } \\
\text { especializadas } \\
\text { em RHs, de } \\
\text { entidades de } \\
\text { classe e } \\
\text { associações } \\
\text { comunitárias }\end{array}$ & $\begin{array}{c}\text { CREA } \\
\text { OAB }-24^{a} \text { Subsecção - Sorocaba } \\
\text { SINTAEMA } \\
\text { Associação Sorocabana de Imprensa } \\
\text { Plenu Instituto Plena Cidadania } \\
\text { Associação Ecológica ICATU } \\
\text { Centro de Est. e Apoio ao Desenv. e Cidadania } \\
\text { los Eng. Arquitetos e Agrônomos de São Roque e M }\end{array}$ & $\begin{array}{c}\text { OAB - Secção de São Paulo - Itu } \\
\text { Ação da Cidadania - Comitê Ibiúna } \\
\text { Centro de Est. e Apoio ao Desenv. e Cidadania } \\
\text { CREA } \\
\text { CREA } \\
\text { OAB - } 24^{\circ} \text { Subseção de Sorocaba } \\
\text { Sindicato Rural de Ibiúna } \\
\text { Sindicato Rural de Ibiúna }\end{array}$ & $\begin{array}{c}\text { Ass. dos Gestores pela Unidade Ambiental } \\
\text { Plenu Instituto Plena Cidadania } \\
\text { Ação da Cidadania - Comitê Ibiúna /SP } \\
\text { Centro de Est. e Apoio ao Desenv. e Cidadania } \\
\text { Soc. dos Jardins Novo Bandeirantes e Apino } \\
\text { Associação dos Amigos do Bairro } 25 \text { - AA25 } \\
\text { OAB - } 24^{\circ} \text { Subseção de Sorocaba } \\
\text { Associação Ecológica ICATU } \\
\text { Sindicato Rural de Piedade } \\
\text { Sind. das Ind. de Extração de Areia }\end{array}$ \\
\hline $\begin{array}{c}\text { Índice de } \\
\text { Permanência }\end{array}$ & $63 \%$ & $50 \%$ & $38 \%$ \\
\hline $\begin{array}{l}\text { Universidades, } \\
\text { Institutos de } \\
\text { Ensino }\end{array}$ & $\begin{array}{c}\text { Universidade de Sorocaba - UNISO } \\
\text { UFSCAR - Campus Sorocaba } \\
\text { Faculdades Evolução } \\
\text { Consórcio Intermunicipal Ribeirão Piraí } \\
\text { Faculdade de Ciências Agronômicas - UNESP } \\
\text { UNESP Sorocaba } \\
\text { Instituto de Estudos Vale do Tietê - INEVAT } \\
\text { Faculdade de Filosofia, Ciências e Letras de Tatuí }\end{array}$ & $\begin{array}{c}\text { Cooperativa de Reciclagem Renascer } \\
\text { Instituto de Estudos do Vale do Tietê - Inevat } \\
\text { Instituto de Estudos do Vale do Tietê - Inevat } \\
\text { Instituto de Pesquisa e Desenvolvimento - Taipal } \\
5 \text { Elementos Instituto de Educ. e Pesquisa Amb. } \\
\text { Unesp - Botucatu } \\
\text { Uniso - Sorocaba } \\
\text { Unesp - Sorocaba }\end{array}$ & $\begin{array}{c}\text { Universidade de Sorocaba - UNISO } \\
\text { UFSCAR - Campus Sorocaba } \\
\text { UNESP Sorocaba UNESP } \\
\text { Unesp - Botucatu } \\
\text { Instituto de Estudos Vale do Tietê - INEVAT } \\
\text { PUC }\end{array}$ \\
\hline $\begin{array}{c}\text { Índice de } \\
\text { Permanência }\end{array}$ & $50 \%$ & $63 \%$ & $50 \%$ \\
\hline
\end{tabular}

*Em azul: Entidades da Sociedade Civil que permaneceram de uma Gestão para outra.

Fonte: Dados obtidos de CBH-SMT $\mathrm{n}^{\circ}$ 253/2011. Elaborado pelo autor. 
Tabela 8. Permanência das Entidades da Sociedade Civil ao longo das Gestões de 2013 a 2015

\begin{tabular}{|c|c|c|c|}
\hline \multicolumn{4}{|c|}{ 2013-2015 } \\
\hline $\begin{array}{c}\text { Entidades } \\
\text { Ambientalistas }\end{array}$ & $\begin{array}{c}\text { Associação Ecológica S. Francisco de Assis } \\
\text { Instituto Cahon } \\
\text { Instituto Plena Cidadania PLENU } \\
\text { Instituto De Projetos e Pesquisas Sócio Amb. } \\
\text { Associação Ecológica ICATU } \\
\text { ALERTA } \\
\text { SOS Mata Atlântica } \\
\text { Instituto Refloresta }\end{array}$ & $\begin{array}{l}\text { Associações } \\
\text { especializadas } \\
\text { em RHs, de } \\
\text { entidades de } \\
\text { classe e } \\
\text { associações } \\
\text { comunitárias }\end{array}$ & 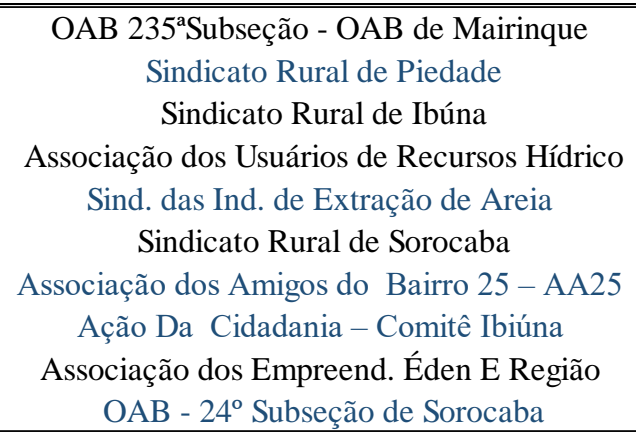 \\
\hline $\begin{array}{c}\text { Índice de } \\
\text { Permanência } \\
\end{array}$ & $50 \%$ & & $50 \%$ \\
\hline $\begin{array}{l}\text { Usuários das } \\
\text { águas, } \\
\text { representados } \\
\text { por Entidades } \\
\text { Associativas }\end{array}$ & $\begin{array}{c}\text { SINTAEMA } \\
\text { CIESP - Sorocaba } \\
\text { Sind. das Conc. Privadas de Água e Esgoto } \\
\text { FIESP } \\
\text { CIESP - Botucatu } \\
\text { União Agroindústria Canavieira de São Paulo } \\
\text { Centro de Est. e Apoio ao Desenv. e Cidadania } \\
\text { Consórcio Intermunicipal Do Ribeirão Piraí }\end{array}$ & $\begin{array}{l}\text { Universidades, } \\
\text { Institutos de } \\
\text { Ensino }\end{array}$ & $\begin{array}{c}\text { Universidade De Sorocaba - UNISO } \\
\text { Universidade Federal De São Carlos - UFSCar } \\
\text { Instituto De Estudos Vale Do Tietê - INEVAT } \\
\text { PUC - Fundação São Paulo FUNDASP } \\
\text { FCA - Unesp Botucatu } \\
\text { Unesp Sorocaba } \\
\text { Fundação Educacional Ipanema } \\
\text { Faculdade De Tecnologia - FATEC Tatuí }\end{array}$ \\
\hline $\begin{array}{c}\text { Índice de } \\
\text { Permanência }\end{array}$ & $50 \%$ & & $83 \%$ \\
\hline
\end{tabular}

*Em azul: Entidades da Sociedade Civil que permaneceram de uma Gestão para outra

Fonte: Dados obtidos de CBH-SMT no 253/2011. Elaborado pelo autor. 


\begin{tabular}{cc} 
Tabela 9. Compilação da participação dos representantes da Sociedade Civil em todos os mandatos \\
\hline Entidades da Sociedade Civil & $\begin{array}{c}\text { Índice de } \\
\text { Permanência (\%) }\end{array}$ \\
\hline \hline Ambientalistas & 53 \\
Usuários das águas, representados por Entidades Associativas & 60 \\
$\begin{array}{c}\text { Associações especializadas em RHs, de entidades de classe e } \\
\text { associações comunitárias } \\
\text { Universidades, Institutos de Ensino }\end{array}$ & 44 \\
Média Total & 67 \\
\hline
\end{tabular}

De acordo com o entrevistado da Sociedade Civil ${ }^{1}$, o que se observa é que mesmo havendo considerável renovação das instituições de uma gestão para outra, os indivíduos em grande parte ainda se mantêm ${ }^{2}$, porém, representando instituições diferentes. Assim, mais do que uma alta renovação, o que se observa é uma alta rotatividade dos indivíduos com relação às instituições. Ainda, de acordo com o entrevistado, a maior parte das pessoas que participam do Comitê, já o faz há quase 10 anos. Muitos participam representando o setor municipal e em determinado momento passam para Sociedade Civil (saem do Governo, mas possuem ou participam de uma ONG na qual continuam atuando).

Diante desse cenário de rotatividade dos atores de uma instituição para outra, ou ainda de um segmento de representação para outro, o questionamento que se faz é até que ponto esses atores de fato conseguem representar os órgãos e as pessoas que o indicaram para ser representantes. Freitas (2013), ao analisar o conteúdo da representação, observou uma forte posição ambígua por parte de alguns representantes. Em certos momentos, defendendo interesses do seu grupo atual, porém, muitas vezes o que prevalece são seus próprios interesses (interesses difusos). Para dificultar ainda mais essa situação, a representação do segmento Sociedade Civil é exercida por entidades de diversos segmentos, configurando-se em um espaço de pluralidades de atores e relações marcadas pelo conflito, consenso e cooperação. Assim, nesse contexto, não fica evidente como se dá realmente a interface dos representantes com a entidade que ele representa, bem como, qual a sua legitimidade junto ao seu público (FREITAS, 2013). Diante disso, a questão que se impõe é até que ponto essa rotatividade de atores entre as diferentes instituições,

\footnotetext{
${ }^{1}$ Entrevista realizada em 2018 com representante da Sociedade Civil do CBH-SMT.

${ }^{2}$ Sobre Estudo de Caso que trata da permanência de representantes em CBHs, veja Fracalanza, 2017.
} 
bem como essa diversidade de interesses entre representante/representado pode impactar negativamente o processo de representação.

\subsection{Considerações Finais do Capítulo}

Com esse Capítulo, foi possível compreender algumas características físicas e socioambientais da Bacia Hidrográfica do Sorocaba e Médio Tietê. Pôde-se constatar que os índices de vegetação natural remanescentes em toda a Bacia não ultrapassam $2 \%$, o que acarreta diretamente na grande quantidade de processos erosivos. Os dados mostram que mais de $27 \%$ da área de toda a Bacia está enquadrada como de médio a alto grau de suscetibilidade à erosão, sendo a maior parte localizada na área de cobertura do Aquífero Guarani, o que agrava ainda mais a situação.

Quanto ao Saneamento Básico, o Relatório de Situação foi enfático ao afirmar que devem-se manter os incentivos a projetos de coleta e tratamento de esgotos nos municípios, com o intuito de manter crescentes os índices de coleta e tratamento de esgotos. Também mostrou a importância dada pelo Comitê a projetos na área de reciclagem e de Educação Ambiental, a fim de reduzir a produção de resíduos, bem como projetos relacionados à ampliação do monitoramento quali/quantitativo na Bacia com o intuito de se fazer um acompanhamento mais preciso dos corpos hídricos. Todas essas constatações devem ser levadas em consideração no momento da hierarquização dos projetos encaminhados ao Comitê para concorrer aos recursos do FEHIDRO.

Por fim, o tópico de gestão de recursos hídricos mostrou que há uma alta rotatividade das instituições representadas pela sociedade civil nas instâncias de gestão do Comitê. Essa informação foi constatada ao serem analisados os órgãos desse segmento ao longo de todas as gestões (Tabelas 5 a 8). Foram ao todo 107 entidades diferentes que se alternaram entre as 34 vagas existentes (Titular e Suplente). Essas 107 entidades são subdivididas em 4 grandes grupos, o que as tornam ainda mais heterogêneas.

Também pôde-se constatar que mesmo havendo essa rotatividade, os mesmos atores persistem de uma gestão para outra, apenas representando instituições diferentes ou mesmo em segmentos diferentes de representação. De acordo com Jacobi (2009), a aprendizagem social exige tempo e constância no sistema; porém, a renovação também se faz necessária, uma vez que a presença constante dos mesmos atores pode resultar em estagnações das ações dentro do Comitê. 


\section{CAPÍTULO 3}

\section{RECURSOS FEHIDRO NA BACIA DO SOROCABA E MÉDIO TIETÊ: CRITÉRIOS DE DISTRIBUIÇÃO E CARACTERIZAÇÃO DOS PROJETOS FINANCIADOS}

Esse capítulo propõe apresentar, inicialmente, os critérios que foram utilizados para a hierarquização dos projetos na Bacia do Sorocaba e Médio Tietê e os temas prioritários adotados pelo Comitê ao longo de toda a sua gestão, de 1995 a 2016. Em seguida, foi feita uma análise dos tipos de projetos que foram encaminhados/aprovados, com relação ao segmento tomador, ao PDC enquadrado, à abrangência territorial e ao tipo de recurso, de modo a identificar se esses projetos financiados refletem de fato as prioridades contidas no seu Plano de Bacia, prioridades estas estabelecidas pelo Comitê de Bacia Hidrográfica. Todos os projetos encaminhados nesse período estão relacionados no Anexo 2 desse trabalho.

\subsection{Critérios Utilizados para Hierarquização dos Projetos na Bacia do Sorocaba e Médio Tietê - Estudo das Deliberações do Comitê}

Nesse item serão analisadas todas as deliberações elaboradas pelo Comitê com relação aos critérios utilizados para a hierarquização dos projetos que almejam tomar recursos do FEHIDRO. A partir dos resultados alcançados, foi possível compreender quais as áreas prioritárias adotadas pelo Comitê ao longo da sua gestão. A análise foi feita a partir de uma divisão em períodos. Esses períodos foram selecionados em função dos diferentes métodos de hierarquização utilizados e dos anseios dos representantes do Comitê para a bacia ao longo dos anos e das gestões.

Com relação à definição dos critérios de pontuação, segundo o entrevistado da Sociedade $\mathrm{Civil}^{3}$, sempre há muito debate no processo de elaboração das deliberações, entretanto, na maioria das vezes consegue-se chegar a um consenso, pois a base a ser consultada é o que está disposto no Plano de Bacia.

Quanto à participação, constata-se que há um certo equilíbrio entre os diversos atores e instituições. Contudo, deve-se considerar que os membros da Sociedade Civil não são só constituídos por ONGs, há também Universidades, órgãos profissionais

\footnotetext{
${ }^{3}$ Entrevista realizada em 2018 com representante da Sociedade Civil do CBH-SMT.
} 
(FIESP/CIESP), Sindicatos Rurais. A questão de ser mais ou menos atuante, segundo o entrevistado está mais relacionada ao tempo de permanência do representante no Comitê do que propriamente ao segmento que ele representa. Até porque, como visto anteriormente, há uma permuta muito grande dos representantes entre as diversas categorias. Na entrevista, considera-se também que há uma maior aceitação com relação às opiniões dos técnicos mais antigos, ou seja, eles passam a ser ouvidos preferencialmente. Isso não significa que eles possuam um peso maior, apenas que suas opiniões são levadas mais em consideração na hora da tomada de decisão.

\subsubsection{Período de 1995 a 2000}

Esse período foi marcado pela implantação do Comitê da Bacia Hidrográfica do Sorocaba e Médio Tietê e por grande mobilização e esforços para apresentar à população a importância do Comitê para a região, bem como, a importância da participação da Sociedade Civil no processo. Os esforços também se voltaram na tentativa de elaborar um diagnóstico da realidade local. Esse diagnóstico foi efetuado a partir do Relatório de Situação de 1995, conhecido como Relatório Zero, que foi o primeiro documento realizado pelo Comitê mediante grandes esforços de mobilização da população local. A partir daí, foram definidas as diretrizes para o Gerenciamento e fornecidos elementos para a priorização dos projetos concorrentes aos recursos do FEHIDRO. Diante desse contexto, a partir das Deliberações consultadas, foi possível observar que passaram a ser priorizados os projetos que possuíam relação com a preservação e recuperação das áreas dos mananciais de Itupararanga e Barra Bonita.

No percorrer dos anos (período de 1996 a 2000), pôde-se constatar através das Deliberações CBH-SMT 07/1995, 08/1996, 26/1997, 31/1998 e 50/1999, que os projetos voltados à preservação das áreas de mananciais ainda estavam presentes na priorização. Entretanto, o Comitê passou a se preocupar também com a recuperação sanitária dos cursos d'água, priorizando projetos com o enfoque no tratamento dos esgotos urbanos. Também passaram a ser definidos como prioridade de investimentos, a promoção de programas de recuperação de áreas críticas de erosão, os programas voltados à destinação adequada de resíduos sólidos e o desenvolvimento de estudos para a caracterização da situação atual e perspectivas futuras da bacia dos Rios Sorocaba e Médio Tietê, subsidiando os Planos Diretores Municipais. 


\subsubsection{Período de 2001 a 2009}

Já a partir de 2000, o Comitê passa por um processo de fortalecimento institucional dos seus integrantes. É nesse período que diversas reinvindicações provenientes principalmente da Sociedade Civil passam a ser atendidas, e por pressão dos membros do Comitê (principalmente por membros da CTPLAGRHI e do GT Itupararanga), cria-se a Área de Proteção Ambiental (APA) de Itupararanga, a partir de mais de 4.000 assinaturas, mostrando a importância do Comitê como intermediador desse processo de negociação. É diante desse cenário que serão determinados os projetos que deverão ser financiados nesse período. Projetos voltados à Preservação e Recuperação das áreas de mananciais receberam uma alta pontuação devido a todo esse movimento de mobilização da sociedade civil no sentido de criação da APA. Trata-se também de um período de aperfeiçoamento do sistema com o amadurecimento do processo de seleção. Agora, a seleção ocorre a partir da atribuição de pesos para cada critério. Os dados consolidados dessas pontuações podem ser visualizados no Quadro 6 (elaborada com base na Deliberação CBH-SMT nº 80/2001).

Esse Quadro mostra uma tendência do Comitê, nesse período, em financiar projetos de Educação Ambiental, Recuperação dos Mananciais e Destinação dos Resíduos Sólidos. Também há a priorização de projetos de abrangência regional e de curta duração.

Para o ano de 2002, o critério relacionado à Preservação e Recuperação de Mananciais obteve um peso menor ( 4 pontos). Por outro lado, tratamento de esgotos passou de 3 para 5 pontos. Ainda nesse ano, projetos localizados em bacia de drenagem de manancial de abastecimento passaram a receber 3 pontos (Deliberação CBH-SMT 91/2002).

Os critérios só voltaram a ter uma alteração significativa em 2006, ano que foi dada ênfase a empreendimentos relacionados à coleta seletiva (Deliberação CBH-SMT 184/2006).

Outra mudança significativa ocorreu em 2008. Nesse ano, a pontuação para projetos relacionados à erosão disparou, passando de 2 para 15 pontos. Neste sentido, cabe ressaltar também que o Plano de Bacia de 2008 constata que a Bacia apresenta porções de muito alta e alta suscetibilidade a processos erosivos (Deliberação CBH-SMT 202/2008). 
Quadro 6. Pontuações atribuídas pelo CBH-SMT a cada critério em $2001^{4}$

\begin{tabular}{|c|c|}
\hline & Quanto aos Objetivos do Empreendimento \\
\hline \multicolumn{2}{|c|}{ Pontos } \\
\hline 5 & Educação Ambiental e Capacitação para Gerencimento de RHs \\
\hline 5 & Preservação e Recupe ração de Mananciais \\
\hline 4 & Dest inação de Lixo \\
\hline 3 & Tratame nto de esgotos \\
\hline 2 & Recupe ração de Áre as Críticas de Erosão \\
\hline \multicolumn{2}{|r|}{ Quanto à População Atendida } \\
\hline 5 & Regional (Toda a Bacia) \\
\hline 3 & Mais de 1 município \\
\hline 2 & 1 Município \\
\hline 1 & Local \\
\hline \multicolumn{2}{|r|}{ Quanto aos Prazos } \\
\hline 5 & Início e Conclusão em até 6 meses \\
\hline 3 & Início e Conclusão acima de 6 meses, com execução mínima de $50 \%$ nos primeiros 6 meses \\
\hline 1 & Acima de doze meses \\
\hline \multicolumn{2}{|r|}{ Quanto à Disponibilidade de Área } \\
\hline 5 & Escritura Definitiva \\
\hline 4 & Documentação de Emissão de Posse \\
\hline 3 & Decretos de Utilizade Pública/Desapropriação/Servidão \\
\hline 2 & Compromisso de Cessão de Doação \\
\hline \multicolumn{2}{|r|}{ Quanto à Contrapartida } \\
\hline 5 & Mais de $81 \%$ \\
\hline 4 & De $61 \%$ a $80 \%$ \\
\hline 3 & De $41 \%$ a $60 \%$ \\
\hline 2 & De $20 \%$ a $40 \%$ \\
\hline
\end{tabular}

Fonte: Elaborado a partir da Deliberação CBH-SMT no 80, 2001

Outros temas que foram bastante priorizados pelo Comitê em 2008 foram a conservação e recuperação de vegetação nativa, o monitoramento hidrológico e a capacitação ambiental, todos na ordem dos 15 pontos cada. Essa alta pontuação ocorreu em decorrência da inexpressiva cobertura vegetal nativa, apenas 13,6\% do território da UGRHI, segundo o Plano de Bacia.

O próprio Plano de Bacia indica como prioridade o Tratamento de Esgoto; assim, essa área torna-se fundamental de ser considerada, ou seja, área em que o Comitê irá

\footnotetext{
${ }^{4}$ Ano em que a classificação dos temas prioritários passou a ser a partir da atribuição de pontuações.
} 
desembolsar a maior parte dos recursos (geralmente terá uma pontuação mais elevada no processo de seleção).

Segundo o entrevistado da Sociedade Civil ${ }^{5}$, outro ponto bastante discutido dentro do Comitê é a questão do reflorestamento/recuperação da Bacia. O que ocorre nesse caso, é que são atribuídas altas pontuações para esse tipo de atividade; porém, de acordo com o apontado na entrevista, o que falta são os tomadores apresentarem mais projetos nessa área. Isso porque o segmento que mais capta recursos no geral são os municípios, porém, com relação a esse tema, eles possuem dificuldades em encontrar áreas propícias para recomposição. Também possuem dificuldades em realizar o reflorestamento quando a área não é pública. O que eles alegam, segundo o entrevistado, é que se fizerem algo em área pública, podem ficar inviabilizados para desenvolver alguma outra atividade nessa área posteriormente.

Já em 2009, a dinâmica de hierarquização foi um pouco modificada. O Conselho Estadual de Recursos Hídricos aprovou uma nova Deliberação (Deliberação CRH $n^{\circ}$ 97/2009), que determinou que cada UGRHI deveria aplicar no mínimo $20 \%$ dos recursos nos projetos de demanda induzida relacionados à Recuperação de córregos urbanos e de mata ciliar ou nascentes.

Os projetos voltados à recuperação de córregos urbanos deveriam ter a finalidade de: melhorar as condições sanitárias dos córregos, mediante tratamento dos esgotos; recuperar os córregos com circulação das águas a céu aberto e criação de espaços públicos de lazer; envolver a população do entorno do córrego, desde a apresentação da proposta do projeto até a execução dos serviços e obras, para que a comunidade usufrua dos novos espaços criados e ajude a conservar o córrego.

Já, os projetos com o intuito de recuperar as matas ciliares e as nascentes deveriam possuir as seguintes diretrizes: elaboração de Planos Diretores de Recomposição Florestal visando à conservação de recursos hídricos; elaboração de projetos regionais ou locais de recuperação de nascentes ou de matas ciliares, com o envolvimento dos proprietários desde as fases iniciais e na manutenção das áreas; implantação de projetos de recuperação de nascentes e de matas ciliares.

\footnotetext{
${ }^{5}$ Entrevista realizada em 2018 com representante da Sociedade Civil do CBH-SMT.
} 


\subsubsection{Período de 2010 a 2016}

O último período (2010 a 2016), ficou conhecido como o de consolidação do modelo de Gerenciamento dos Recursos Hídricos. A partir de 2010, temos a implementação do importante instrumento da Cobrança pelo Uso da Água e a disponibilização de mais recursos para incrementar o financiamento de projetos nas áreas prioritárias. O Comitê decidiu manter cada tema prioritário diretamente atrelado às metas do Plano de Bacia, sendo definido, de acordo com as Deliberações consultadas, que os projetos localizados em mananciais de abastecimento público continuariam a ser priorizados frente aos demais. Também passaram a ser priorizados os projetos voltados à disposição final de resíduos sólidos urbanos e à Recomposição de Mata Ciliar, principalmente em áreas com alta e média suscetibilidade à erosão, tal como demonstrado no Quadro 7 (CBH-SMT 249/2010; 265/2011; 273/2012; 307/2013; 324/2014; 342/2015; $355 / 2016)$.

Como pôde ser analisado, os critérios de priorização e hierarquização adotados pelo Comitê do Sorocaba, divulgados a partir de Deliberações anuais, possuem o objetivo de selecionar projetos que tenham foco na redução da carga poluidora dos corpos hídricos; na disposição adequada de resíduos sólidos; na ampliação e melhoria dos sistemas de drenagem e na recuperação de áreas contaminadas, sempre priorizando os projetos que possuam abrangência mais regional e que estejam interligados às áreas de mananciais. $O$ Comitê também especifica em suas Deliberações que os projetos devem possuir mecanismos factíveis de envolvimento com a comunidade, de forma a garantir a sua sustentabilidade durante e após a sua execução. A partir de 2001, o sistema de seleção passou a ser por pontuações, tornando o processo mais claro e objetivo. Conforme foi verificado, de acordo com entrevista realizada, apesar de todos os debates existentes na hora de priorização dos projetos, na maior parte das vezes consegue-se chegar a um consenso, uma vez que a referência tem sido o que está disposto no Plano de Bacia.

Nessa atividade de proposição de critérios para a seleção de projetos, foi possível constatar a importância dos aprendizados trazidos com a Governança Ambiental. Nesse contexto, mais do que eliminar os conflitos existentes, a governança propõe administrálos da melhor maneira, de acordo com as propostas coletivas. Para isso, é importante que sejam considerados os valores e as visões de mundo dos atores incluídos no sistema. O entendimento também deve ser baseado em um processo participativo e de aprendizagem constantes (FRACALANZA, 2016). 
Quadro 7. Pontuações atribuídas pelo CBH-SMT a cada critério

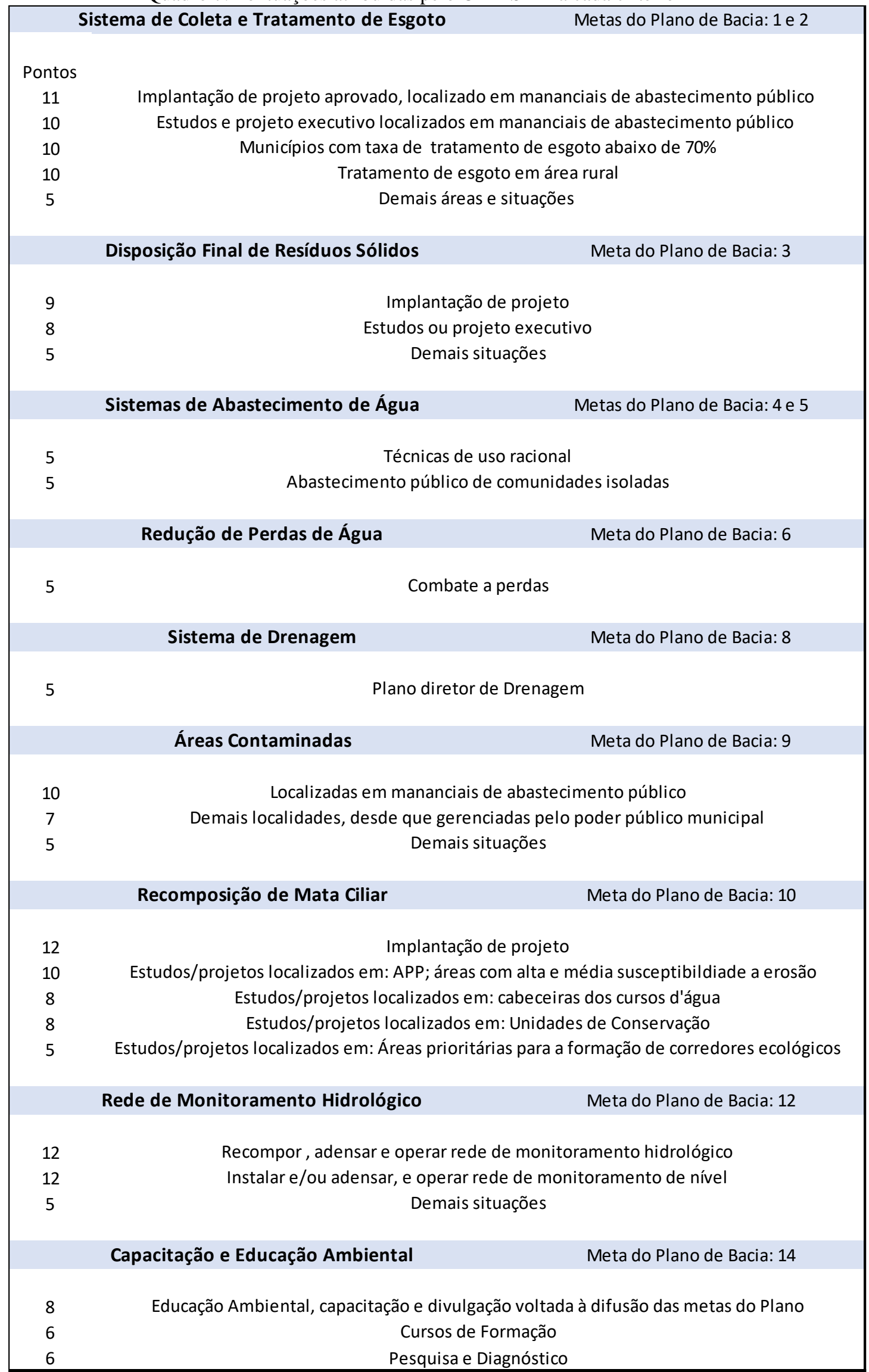

Fonte: Elaborado a partir das Deliberações CBH-SMT 
A partir dessa metodologia implementada pelo Comitê, pode-se então analisar de que forma esse processo influenciou no financiamento de projetos que possam refletir de fato os anseios trazidos pelo Plano de Bacia.

\subsection{Análise dos Projetos Encaminhados e Financiados pelo FEHIDRO na Bacia do Sorocaba e Médio Tietê}

Com o intuito de compreender a dinâmica de implementação dos projetos na Bacia, as seguintes características foram analisadas: PDC enquadrado; segmento que tomou o recurso; duração do projeto; situação do empreendimento; compensação e cobrança, entre outras. No período analisado, de 1995 a 2016, o Fundo obteve a marca de 447 empreendimentos encaminhados e 261 efetivamente financiados. As principais ações foram relativas à capacitação e educação ambiental, coleta e tratamento de esgoto e destinação adequada dos resíduos sólidos. Desse total, 264 empreendimentos (59\%) pleitearam recursos para estudos/projetos/planos, 100 (22\%) para obras e 83 (19\%) para serviços. Suas principais características estão descritas a seguir.

\subsubsection{Projetos Encaminhados no Período de 1995 a 2016}

Quando se toma como base todo o período analisado (de 1995 a 2016), os projetos encaminhados ao Comitê foram distribuídos da seguinte maneira, de acordo com as Metas estipuladas pelo Plano de Bacia do SMT (Figura 13).

Como observado na Figura 13, a maior quantidade de projetos está atrelada às seguintes metas do Plano de Bacia: 14 (adoção de mecanismos de pesquisa e capacitação tecnológica e educação ambiental para todos os segmentos do Comitê); 1 e 2 (alcance e/ou manutenção de 100\% na coleta de esgoto urbano e 100\% de esgoto urbano tratado);

3 (implantação e/ou adequação de sistemas de destinação final de resíduos sólidos domiciliares); e, 7 (Combater os problemas de erosão urbana de médio e grande porte em 83 feições já cadastradas). 


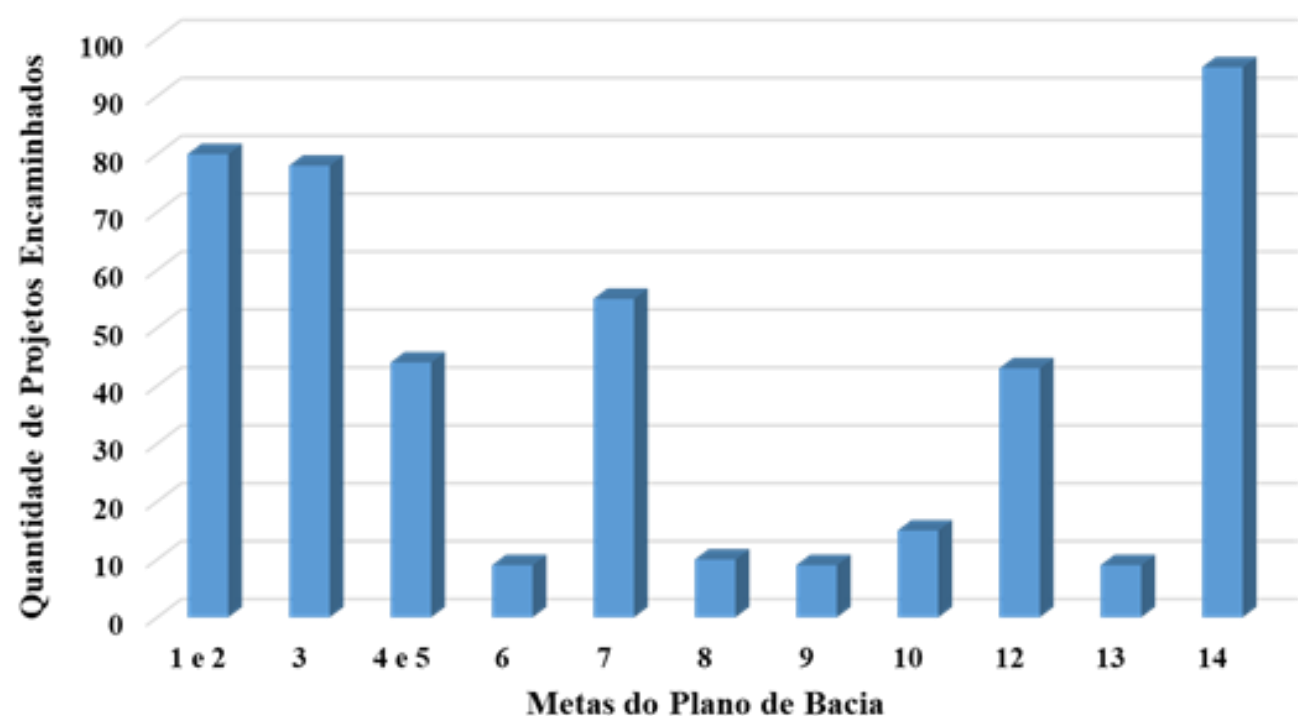

Metas do Plano de Bacia
1: Alcançar e/ou manter $100 \%$ na coleta do esgoto urbano:

2: Alcançar e/ou manter $100 \%$ de esgoto urbano tratado;

3: Implantar e/ou ampliar e/ou adequar e/ou recuperar sistemas de destinação de resíduos sólidos domiciliares nos 34 municípios da Bacia;

4: Alcançar e/ou manter a universalização na distribuição de água;

5: Alcançar e/ou manter a universalização no tratamento de água;

6: Elaborar programas de conservação de água, para combate a perdas, nos municípios da Bacia;

7: Combater os problemas de erosão urbana de médio e grande porte em 83 feições já cadastradas;

8: Elaborar Planos Diretores de Macrodrenagem Urbana, para todas as cidades com mais de 10.000 habitantes;

9: Efetuar estudos para delimitação de áreas de restrição e controle do uso das águas subterrâneas, em 15 locais contaminados;

10: Diminuir em $30 \%$ o déficit atual de vegetação em Áreas de Preservação Permanente;

11: Diminuir em $10 \%$ o déficit atual de vegetação, de Reserva Legal;

12: Recompor, adensar e recuperar redes de monitoramento hidrológico;

13: Preparar e manter as bases técnicas necessárias para o gerenciamento de recursos hídricos da Bacia;

14: Adotar e manter atualizados os mecanismos de pesquisa, capacitação $\mathrm{e}$ educação ambiental, para todos os segmentos do Comitê.

Figura 13. Quantidade de Projetos Encaminhados e as Metas do Plano de Bacia

Fonte: Dados do SINFEHIDRO, 2017. Elaborado pelo autor 
Com o intuito de compreender se essas Ações/Metas contidas no Plano de Bacia foram de fato refletidas nos projetos encaminhados/financiados com recursos do FEHIDRO, foi feito um levantamento comparando essas ações relativas a cada área e os tipos de projetos que foram encaminhados e que possuíam alguma relação com a ação designada do Plano, sendo essa divisão feita por município. Diante disso, chega-se aos seguintes resultados.

\section{Coleta e Tratamento de Esgoto (Metas 1 e 2)}

Com relação à implantação e/ou ampliação da rede coletora de esgoto e estação de tratamento de esgoto, o Plano de Bacia priorizou os seguintes municípios: Jumirim, Sorocaba, Capela do Alto, Iperó, Itu, Boituva, São Roque, Ibiúna, Cabreúva e Porto Feliz, devido a suas fragilidades à época. Observando os projetos encaminhados/financiados, foi possível observar que todos esses municípios obtiveram pelo menos um projeto financiado que possuía alguma relação com a meta estipulada. A exceção ocorreu em Itu e Cabreúva, que não receberam projetos nessa área, apesar de também terem sido considerados prioritários. As ações específicas do Plano de Bacia e os projetos encaminhados para cada tipo de segmento podem ser visualizados abaixo:

I. Ação do Plano de Bacia: Ampliação da rede coletora e implantação de rede de afastamento de esgoto doméstico em Jumirim.

Projetos Encaminhados: Supressão do lançamento de efluentes em córrego ao lado da Rodovia Marechal Rondon (Segmento tomador: Município, concluído); Rede coletora, emissário e sistema de tratamento (Município, concluído); Ampliação da rede de esgoto e travessia subterrânea (Município, concluído).

\section{Ação do Plano de Bacia: Construção de emissário de esgoto em Sorocaba.}

Projeto Encaminhado: Projeto executivo do emissário de esgotos - margens do rio Sorocaba (Município, concluído).

III. Ação do Plano de Bacia: Elaboração de estação elevatória de esgoto em Capela do Alto.

Projeto Encaminhado: Coleta e tratamento de esgotos do bairro Carcadinho (Município, concluído). O projeto intitulado "Estudos para viabilizar o alcance de $100 \%$ 
do esgoto tratado no município" foi encaminhado pelo Município, porém, foi cancelado por não apresentar objetivos claros.

IV. Ação do Plano de Bacia: Construção de estação elevatória em Iperó.

Projetos Encaminhados: Coleta no bairro Campos Vileta (Município, em execução); Afastamento para tratamento de esgotos gerados no Pronto Atendimento do Município (Município, concluído).

V. Ação do Plano de Bacia: Projetos para afastamento de esgoto em Itu. Não houve projetos na área.

VI. Ação do Plano de Bacia: Construção de estação elevatória em Boituva.

Projeto Encaminhado: Ampliação da rede coletora de esgoto (Município, concluído).

VII. Ação do Plano de Bacia: Sistema de esgoto sanitário em São Roque.

Projeto Encaminhado: Propiciar a futura implantação de sistema de afastamento e tratamento de esgoto urbanos (Estado, concluído). O projeto intitulado "Destinação adequada ao esgoto coletado nas residências de forma a não contaminar o solo" encaminhado pelo Município foi cancelado por falta de contrapartida desse segmento.

VIII. Ação do Plano de Bacia: Ampliação da coleta e tratamento do esgoto sanitário em Ibiúna.

Projeto Encaminhado: Implantação do sistema de afastamento e tratamento de esgotos com melhoria sanitária e ambiental (Estado, concluído).

IX. Ação do Plano de Bacia: Implantação de sistema de tratamento de esgoto de Cabreúva.

Não houve projetos na área.

X. Ação do Plano de Bacia: Previsão do crescimento do município de Porto Feliz, garantindo coleta e transporte de esgoto sanitário de forma planejada.

Projeto Encaminhado: Termo de referência para projeto básico de ETE e elevatória (Município, concluído). 
A partir dos dados levantados, foi possível perceber que o processo de hierarquização conseguiu selecionar projetos que atenderam satisfatoriamente aos municípios elencados no Plano de Bacia no que tange à Meta Coleta e Tratamento de Esgotos. O segmento Município foi o que mais encaminhou projetos e obteve um alto índice de aprovação. Isso demonstra a importância desse tipo de recurso para os municípios para financiar esses tipos de empreendimentos.

Vale destacar também que foi decidido previamente entre os membros do Comitê que a prioridade da Bacia seria a coleta e o tratamento de esgotos (o que consta no seu próprio Plano de Bacia). Com isso, os debates em torno da priorização dos projetos relacionados a esse tema foram mais brandos. Foi acordado também que essa área teria uma alta pontuação, e receberia a maior parte dos desembolsos dos recursos anuais ${ }^{6}$.

Isso vai ao encontro do que mostram Jacobi et. al. (2014), ao tratar de aprendizagem social. A partir da constatação dos principais problemas da Bacia, pelos diversos atores envolvidos, foi possível perceber que houve um maior interesse por parte desses atores na tentativa de solucionar esses problemas levantados. A partir daí, com o encaminhamento das diferentes propostas apresentadas, foi estruturado e construído o Plano de Bacia.

\section{$\underline{\text { Resíduos Sólidos Domiciliares (Meta 3) }}$}

De acordo com o Plano de Bacia, à época, 41,2\% dos municípios apresentavam disposição final dos resíduos sólidos domiciliares em condições não adequadas. Desses, 23,5\% possuíam sua disposição final em condições precárias. A meta sugerida no Plano era priorizar 4 municípios de pequeno porte e disposição final inadequada, tratam-se de: Tatuí, Conchas, Ibiúna, Botucatu e Vargem Grande Paulista. O Plano também trouxe como meta de priorização a Readequação do aterro sanitário do município de Botucatu. Os projetos encaminhados/financiados estão relacionados abaixo:

I. Ação do Plano de Bacia: Ampliação da coleta seletiva no município de Tatuí.

Projetos Encaminhados: Aumentar o número de famílias atendidas, atingindo uma meta de 50 famílias no período de doze meses (Sociedade Civil, cancelado).

\footnotetext{
${ }^{6}$ Entrevista realizada em 2018 com representante da Sociedade Civil do CBH-SMT.
} 
II. Ação do Plano de Bacia: Programa de gerenciamento integrado participativo dos resíduos sólidos gerados no município de Conchas.

Projetos Encaminhados: Programa de gerenciamento integrado participativo dos resíduos sólidos gerados no município de Conchas (Município, concluído).

III. Ação do Plano de Bacia: Implantação da primeira fase do aterro sanitário de Ibiúna e recuperação de área do antigo lixão municipal.

Projetos Encaminhados: Recuperação ambiental da área degradada pelo antigo lixão municipal (Município, concluído); Implantação da primeira fase do aterro sanitário de Ibiúna (Município, concluído).

IV. Ação do Plano de Bacia: Readequação do aterro sanitário do município de Botucatu.

Projetos Encaminhados: Ponto de Entrega Voluntária para logística reversa; (cancelado por falta de contrapartida).

V. Ação do Plano de Bacia: Melhoria no sistema de gerenciamento de resíduos sólidos de Vargem Grande Paulista.

Projetos Encaminhados: Recuperação de área degradada por deposição de resíduos sólidos urbanos (Município, concluído).

Pôde-se perceber que, no período analisado, no que tange às principais metas voltadas aos Resíduos Sólidos Domiciliares, foi encaminhado 1 projeto por parte Sociedade Civil em Tatuí, porém, foi cancelado por não estar condizente com a meta do Plano. Em Conchas, 1 projeto por parte do município relacionado ao gerenciamento integrado participativo dos resíduos sólidos gerados foi financiado e concluído. Em Ibiúna, houve um projeto de recuperação ambiental da área degradada pelo antigo lixão municipal, já concluído e financiado para o segmento Município. Também foi encaminhado 1 projeto relacionado à coleta seletiva, porém, foi cancelado por falta de documentação. Em Botucatu, o projeto de Ponto de Entrega Voluntária para logística reversa foi cancelado pelo Agente Técnico também por falta de contrapartida. Já em Vargem Grande Paulista, foram 3 projetos cancelados, apresentados pelo segmento Município, e 1 projeto financiado também por parte do segmento Município. 
No que tange aos projetos na área de Resíduos Sólidos Urbanos, foi possível perceber que houve uma demanda alta para financiar projetos nos municípios priorizados no Plano de Bacia, porém, poucos projetos foram efetivamente financiados. Os motivos, já demonstrados, vão desde falta de documentação pertinente, até projetos mal elaborados e não condizentes com as metas estipuladas no Plano. Outro fator é por conta da mudança de gestão dos prefeitos, ocasionando assim uma descontinuidade dos projetos e também pela incapacidade técnica de tocar a obra.

\section{Combater os Problemas de Erosão Urbana de Médio e Grande Porte (Meta 7)}

Para o Controle da Erosão, o Plano traz como meta primeiramente resolver os locais mais críticos, ou seja, os municípios que estão em área de maior suscetibilidade. Esses municípios estão nas Sub-Bacias MTI (Médio Tietê Inferior), e AS (Alto Sorocaba), e trata-se de: Anhembi, Bofete, Conchas, Pereiras, Porangaba, Torre de Pedra, Ibiúna e Vargem Grande Paulista. Outra preocupação quanto a esses municípios é que eles também possuem os maiores mananciais de água superficial da UGRHI 10 (Reservatórios de Itupararanga e Barra Bonita), o que agrava ainda mais essa situação. Os projetos encaminhados/financiados a esses municípios priorizados foram:

I. Projetos Encaminhados em Anhembi: Não houve projetos.

II. Projetos Encaminhados em Bofete: Obras de drenagem de águas pluviais para combate e prevenção à erosão nos Conjuntos Habitacionais CDHU 1 e 2 (Estado, concluído). Também foi encaminhado pelo Município o projeto relacionado à elaboração do plano diretor de drenagem urbana para controle e erosão do solo, porém, foi cancelado devido à falta de documentação.

III. Projetos Encaminhados em Botucatu: Plano diretor de drenagem para controle de erosão em Botucatu (Município, em execução);

IV. Projetos Encaminhados em Conchas: Plano diretor de drenagem para controle de erosão em Conchas (Município, em execução);

V. Projetos Encaminhados em Pereiras: Não houve projetos;

VI. Projetos Encaminhados em Porangaba: Não houve projetos;

VII. Projetos Encaminhados em Torre de Pedras: Prevenção e defesa contra erosão do solo e o assoreamento dos corpos d'água em Torre de Pedras (Município, concluído). 
VIII. Projetos Encaminhados em Ibiúna: Melhorar a qualidade das restaurações florestais com vistas à proteção e defesa contra erosão em Ibiúna (Sociedade Civil, concluído).

IX. Projetos Encaminhados em Vargem Grande Paulista: Não houve projetos.

Foi possível perceber que mesmo o Comitê definindo quais são as suas áreas críticas à erosão, e priorizando projetos nessas áreas, a quantidade de projetos encaminhados e financiados nos municípios priorizados foi reduzida, tendo ainda muitos municípios que não apresentaram nenhum tipo de projeto nessa área. Vale destacar que essas áreas críticas elencadas no Plano de Bacia estão localizadas nas Sub-Bacias Médio Tietê Inferior e Alto Sorocaba, que são justamente as áreas onde estão os Reservatórios de Barra Bonita e de Itupararanga, o que agrava ainda mais a situação.

\section{$\underline{\text { Mecanismos de Educação Ambiental para os segmentos do CBH (Meta 14) }}$}

No que tange à Educação Ambiental, o Plano de Bacia traz como objetivo principal a preservação das áreas e a conscientização ambiental das populações. Foram priorizados os projetos que fomentem atividades de educação ambiental voltadas ao ecoturismo na região. Também foram priorizados os projetos que proporcionem a formação e o treinamento de agentes ambientais bem como os projetos de Educação Ambiental voltados à melhoria do gerenciamento de resíduos sólidos, da poluição hídrica, do uso racional da água, do combate à erosão e ao assoreamento. Nesse sentido, as ações estipuladas no Plano de Bacia e os Projetos encaminhados/financiados estão listados a seguir:

I. Ação do Plano de Bacia: Capacitação técnica e melhoria da estruturação dos laboratórios de análise em Itu e Salto.

Projeto em Itu: Atividades de educação ambiental, desassoreamento e reforma do viveiro de mudas. Esse projeto foi encaminhado pela Sociedade Civil, porém, foi cancelado por falta de compatibilização com as metas sugeridas.

II. Salto: não houve projetos.

III. Ação do Plano de Bacia: Programa de educação ambiental nos Altos do Paranapiacaba - Piedade. 
Projeto Financiado em Piedade: Educação Ambiental - Altos do Paranapiacaba. Esse projeto foi encaminhado pela Sociedade Civil, porém, foi cancelado por falta de documentação pertinente.

IV. Ação do Plano de Bacia: Programa de divulgação sobre a APA da represa itupararanga junto à rede escolar - Ibiúna.

Projetos Financiados em Ibiúna: Disseminar alternativas de manejo apropriado da água na zona rural através da Educação Ambiental (Sociedade Civil, concluído); Promover uma campanha voltada à conscientização dos produtores agrícolas (Sociedade Civil, concluído); Propor medidas e ações que estimulem a mudança de comportamento no meio rural (Sociedade Civil, concluído); Tratar o saneamento com uma abordagem socioambiental que deverá promover não só a saúde do homem, mas o seu bem estar (Sociedade Civil, cancelado); Contribuir com a melhoria da qualidade dos recursos hídricos da microbacia do Sorocamirim (Sociedade Civil, em execução); Produção de cartilha sobre a APA de Itupararanga abordando seus aspectos gerais e principais impactos ambientais (Sociedade Civil, concluído).

V. Ação do Plano de Bacia: Projeto líderes mirins como guardiães da água, uma

nova proposta de educação ambiental, em Anhembi, Bofete, Botucatu, Cesário Lange, Conchas, Pereiras, Porangaba e Torre de Pedra.

Projetos Financiados:

Anhembi: Desenvolver programa inovador de educação ambiental, de caráter multiplicador e efetivo (Sociedade Civil, concluído);

Bofete: não houve projetos;

Botucatu: Contribuir para consolidar as condições de conservação, manejo e recuperação dos ambientes naturais (Sociedade Civil, em execução); Construção de centro de educação ambiental em parque municipal (Município, cancelado);

Cesário Lange, Conchas, Pereiras, Porangaba, Torre de Pedra: não houve projetos.

Foi possível observar que foram apresentados muitos projetos na área, principalmente articulados pela Sociedade Civil; porém, a quantidade de projetos cancelados também foi bastante elevada, tanto no quesito ao não atendimento às metas do Plano quanto à falta de algum documento ao longo do processo de contratação. E, às vezes, o tomador também não consegue cumprir os requisitos do Agente Técnico. 
Vale destacar que as ONGs muitas vezes querem realizar projetos na área de Educação Ambiental; porém, os recursos que são destinados para esse tipo de projeto são escassos. Também existe uma tendência entre os avaliadores dentro do Comitê em não valorizar projetos nessa linha, alegando que eles não são muito efetivos ou são de difícil avaliação ${ }^{7}$.

\subsubsection{Total de Projetos Financiados no Período de 1995 a 2016}

Quando analisamos uma amostragem maior, considerando agora todos os projetos que foram efetivamente financiados em todos os municípios (e não somente os municípios prioritários, como no item anterior), têm-se o seguinte cenário (Figura 14):

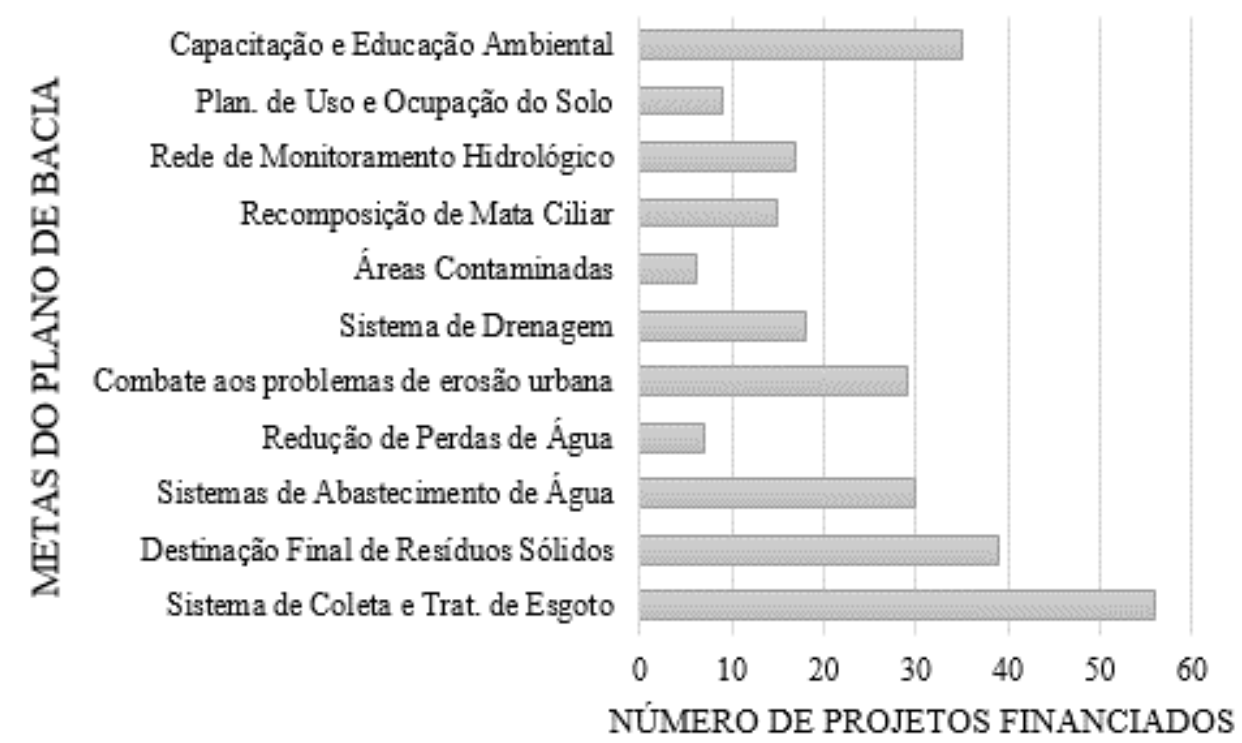

Figura 14. Número de Projetos Financiados no Comitê com relação às Metas do Plano de Bacia Fonte: Elaborado a partir dos dados do SINFEHIDRO, 2017

Dos 447 empreendimentos encaminhados ao Comitê, 261 foram financiados, ou seja, aproximadamente, 59\%. Quando analisamos por linha temática, temos que foram financiados:

I. $70 \%$ dos empreendimentos voltados a Sistema de Coleta e Tratamento de Esgoto;

II. $70 \%$ dos voltados ao Abastecimento de Água;

III. 50\% dos voltados ao Destino Final de Resíduos Sólidos; e,

IV. $40 \%$ dos projetos de Capacitação e Educação Ambiental.

\footnotetext{
${ }^{7}$ Entrevista realizada em 2018 com representante da Sociedade Civil do CBH-SMT.
} 
Embora exista uma grande quantidade de projetos encaminhados na área de Capacitação e Educação Ambiental, o que ficou evidenciado é que a maior parte foi reprovado em alguma etapa do processo. Vale destacar também que mais de $75 \%$ dos projetos encaminhados ao Comitê na área de Educação Ambiental foram elaborados pelo segmento da Sociedade Civil.

De acordo com o entrevistado da Sociedade Civil ${ }^{8}$, diversos membros do Comitê acreditam que os projetos na área de Educação Ambiental não podem ser elaborados sem a presença de um educador, e que os membros da Sociedade Civil e dos municípios geralmente não possuem um profissional nessa área.

O entrevistado também destaca que, antigamente, quem analisava os projetos na área de Educação Ambiental era a Coordenadoria de Educação Ambiental (CEA), ligada à Secretaria de Meio Ambiente (SMA) do Estado de São Paulo. Essa Coordenadoria não aceitava projetos que não tivessem embasamento muito forte na área de Educação. Esse fato também desencorajava as instituições a elaborarem projetos. Diversas ONGs que solicitavam recursos, pararam de fazê-lo.

\subsubsection{Distribuição dos Recursos do FEHIDRO por Segmento}

Ao se analisar os dados do SinFEHIDRO e de informações junto à Secretaria Executiva do Comitê, para o período de 1995 a 2016, pôde-se constatar que o segmento Estado foi o que menos pleiteou recursos - com 26 projetos financiados (aproximadamente 10\%). Por outro lado, o Município foi o que mais buscou financiamento de projetos (173 ou 66\% do total), seguido da Sociedade Civil $(62,24 \%$ do total) (Figura 15). Os recursos, nesse caso, foram os provenientes tanto da Compensação Financeira quanto da Cobrança pelo Uso da Água.

Quando se observa os valores separadamente por Compensação Financeira e Cobrança, tem-se que o primeiro foi responsável por aproximadamente $\mathrm{R} \$ 29$ milhões em financiamento de projetos, enquanto que o segundo, $\mathrm{R} \$ 30$ milhões. Esse dado mostra a importância do instrumento da Cobrança no aporte de recursos para o financiamento de projetos na Bacia. Ainda que a Cobrança só tenha começado em 2010, ela já representa mais da metade de todo o investimento do FEHIDRO para toda Bacia.

\footnotetext{
${ }^{8}$ Entrevista realizada em 2018 com representante da Sociedade Civil do CBH-SMT.
} 


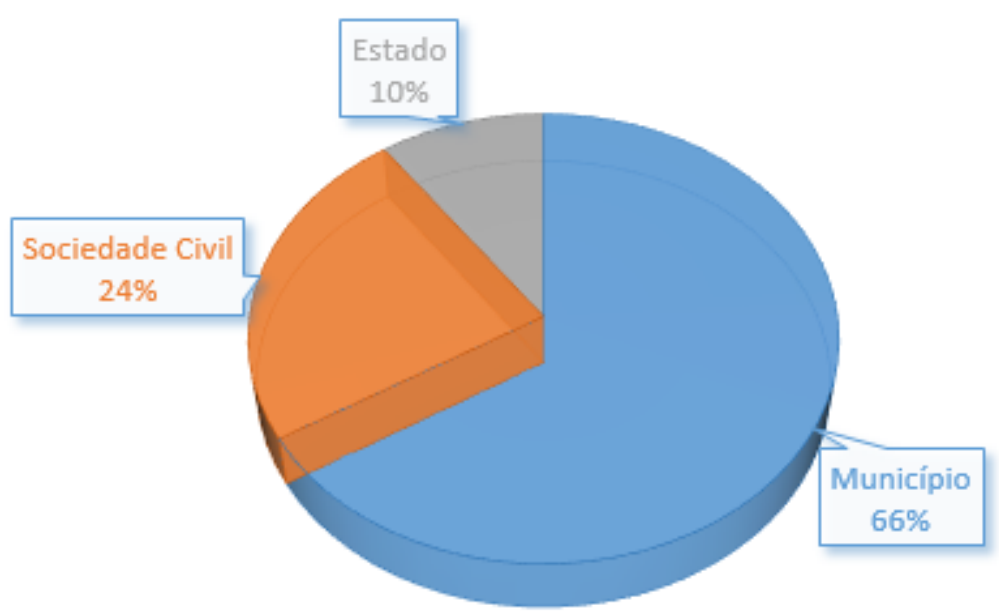

Figura 15. Distribuição por segmento dos projetos financiados e concluídos com recursos FEHIDRO, no período de 1995 a 2016

Fonte: Elaborado a partir dos dados do SINFEHIDRO, 2017

Considerando o financiamento por segmento, tem-se que o município totalizou $\mathrm{R} \$ 33,6 \mathrm{mi}$, seguido da sociedade civil (R\$15,9mi) e do Estado ( $\mathrm{R} \$ 9,9 \mathrm{mi})$.

Ao se analisar a relação entre projetos já financiados pelo FEHIDRO (ou seja, concluídos, não iniciados e em execução) com os projetos cancelados, chegamos à seguinte relação (Tabela 10):

Tabela 10. Relação entre os Projetos Cancelados e os financiados, no período de 1995 a 2016

\begin{tabular}{c|c|c|c}
\hline \hline Segmentos & $\begin{array}{c}\text { Projetos: Concluídos, em execução e } \\
\text { não iniciados (contratados) }\end{array}$ & $\begin{array}{c}\text { Projetos } \\
\text { Cancelados }\end{array}$ & $\begin{array}{c}\text { Relação } \\
\text { Cancelados/Total }\end{array}$ \\
\hline \hline Estado & 26 & 15 & $37 \%$ \\
\hline Município & 173 & 112 & $39 \%$ \\
\hline Sociedade Civil & 62 & 59 & $49 \%$ \\
\hline \hline TOTAL & 261 & 186 & $42 \%$ \\
\hline \hline
\end{tabular}

Fonte: Elaborado a partir dos dados do SINFEHIDRO, 2017

Torna-se claro, a partir das informações levantadas, que a participação da Sociedade Civil e do Estado, para o período analisado, foi inquestionavelmente tímida. A quantidade de projetos contratados desses dois segmentos não representa nem $40 \%$ do total de projetos. Uma possível explicação é a facilidade do Estado em obter recursos de outras fontes para financiamentos, o que pode justificar a sua baixa adesão aos recursos do FEHIDRO. Já, no caso da Sociedade Civil, uma possível causa é a não adequação dos projetos elaborados às exigências do FEHIDRO, ou a má execução desses. Essa segunda hipótese pode ser embasada ao se analisar o alto índice de projetos cancelados (Tabela 10) por parte desse segmento (quase metade de todos os projetos enviados pela Sociedade Civil foram cancelados). 
Ainda no que tange à quantidade de projetos cancelados, a Figura 16 mostra a sua evolução ao longo dos períodos.

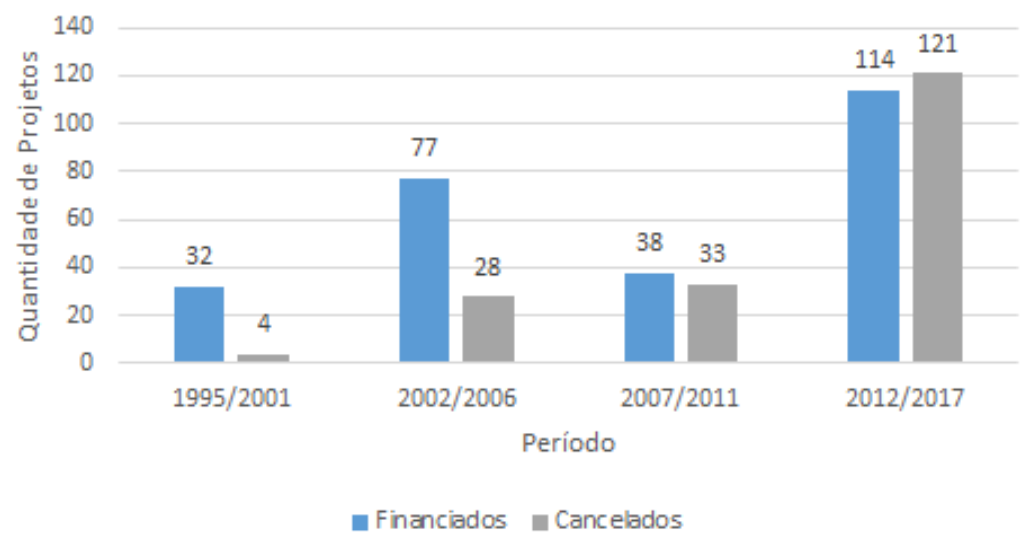

Figura 16. Quantidade de projetos cancelados e financiados por período Fonte: Elaborado a partir dos dados do SINFEHIDRO, 2017

Quando se analisa a relação cancelados/financiados por período, pode-se perceber que houve uma inversão de tendência. Como constatado na Figura 16, a relação inicial de cancelados/financiados era de 1 para 8, passou a ser de aproximadamente 1 para 3, e no último período já havia mais projetos cancelados do que financiados.

Um dos prováveis motivos da elevação de projetos cancelados é justamente o aumento da quantidade de projetos submetidos. Com essa maior procura aos recursos do FEHIDRO, houve um aumento na submissão de projetos incompletos ao Comitê, com falta de documentação necessária ou mal elaborados, bem como, o não cumprimentos das exigências estabelecidas pelos agentes técnicos e financeiros. Outra explicação é que no período de 2010 a 2016, a hierarquização voltou a ficar diretamente atrelada às metas do plano, assim, os tomadores encontraram dificuldades em enquadrar corretamente seus projetos.

\subsubsection{Distribuição dos Recursos do FEHIDRO por PDC}

A Figura 17 traz a quantidade de empreendimentos distribuídos por PDC e por tipo de financiamento (compensação e cobrança). 


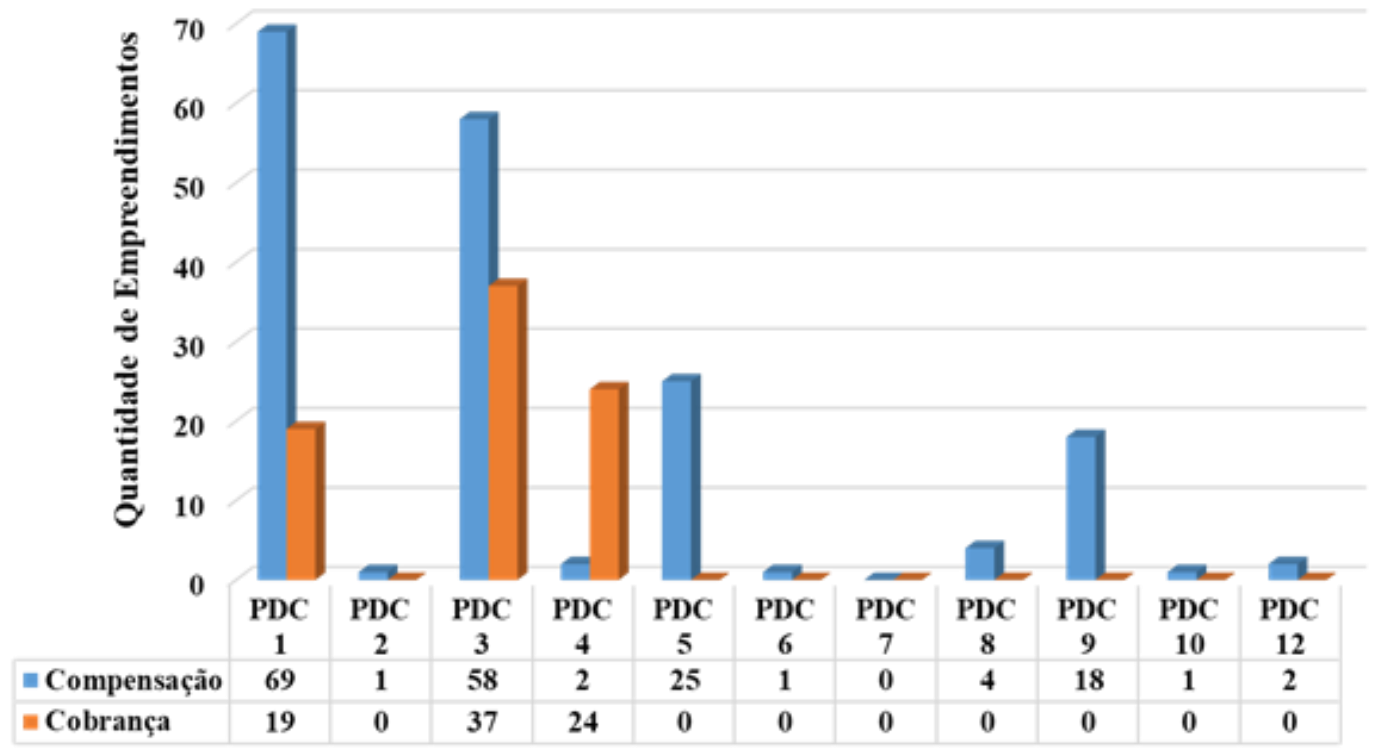

1. Base de Dados, Cadastros, Estudos e Levantamentos - BASE.

2. Gerenciamento dos Recursos Hídricos - PGRH.

3. Recuperação da Qualidade dos Corpos D' Água - RQCA

4. Conservação e Proteção dos Corpos D'Água - CPCA.

5. Promoção do Uso Racional dos Recursos Hídricos - URRH.

6. Aproveitamento Múltiplo dos Recursos Hídricos - AMRH.

7. Prevenção e Defesa contra Eventos Hidrológicos Extremos -

\section{PDEH.}

8. Capacitação Técnica, Educação Ambiental e Comunicação Social - CCEA

9: Prevenção e Defesa contra a Erosão do Solo e o Assoreamento dos Corpos d"Água - PPDE.

10: Desenvolvimento dos Municípios Afetados por Reservatórios e Leis de Proteção de Mananciais - PDMA.

11: Articulação Interestadual e com a União - PAIU.

12: Participação do Setor Privado - PPSP.

Figura 17. Distribuição dos projetos financiados por PDC Fonte: Elaborado a partir dos dados do SINFEHIDRO, 2017 
Os PDCs que mais obtiveram projetos enquadrados foram: PDC 3 (recuperação da qualidade dos corpos d'água) com 95 projetos, seguido pelo PDC 1 (Base de dados, cadastros, estudos e levantamentos) com 88 projetos no total. O PDC 3 apresenta-se em um elevado número devido à decisão colegiada de priorizar projetos que possuam relação direta com os maiores problemas da Bacia. Esses problemas são os relacionados à prevenção e contenção da erosão em áreas urbanas e rurais; à coleta e tratamento de esgoto; e à destinação adequada de resíduos sólidos urbanos. O PDC 1 também é priorizado pelo fato de ser importante na caracterização e diagnóstico da Bacia, identificando seus principais problemas e acompanhando as obras/estudos que já estão em andamento.

Os recursos provenientes da Cobrança estão sendo aplicados nos PDCs 1, 3 e 4, uma vez que o Decreto $\mathrm{n}^{\circ} 55.008 / 2009$ determina que os recursos arrecadados com a cobrança deverão ser obrigatoriamente destinados a esses Programas:

I. PDC1 - Prevista a aplicação de até $20 \%$ do montante arrecadado anualmente;

II. PDC3 - Prevista a aplicação de até $44 \%$ do montante arrecadado anualmente;

III. PDC4 - Prevista a aplicação de até 33\% do montante arrecadado anualmente.

Para o caso dos recursos da Compensação Financeira, não há esse vínculo direto. O Comitê deve decidir anualmente em qual PDC deverão ser aplicados os recursos.

\subsubsection{Distribuição dos Recursos do FEHIDRO por Tempo de Duração}

Quanto à duração do empreendimento, tem-se algumas faixas de tempo: 0 a 6 meses; 6 a 12 meses; 12 a 18 meses; 18 a 24 meses e acima de 24 meses. A análise quanto a esse parâmetro foi realizada separando os projetos financiados com recursos da compensação financeira e com recursos da cobrança, tal como observado na Figura 18.

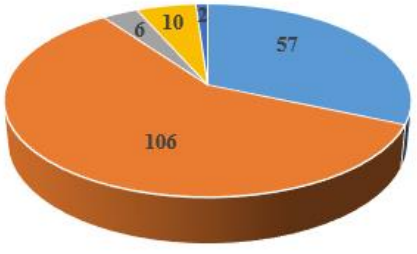

(a)

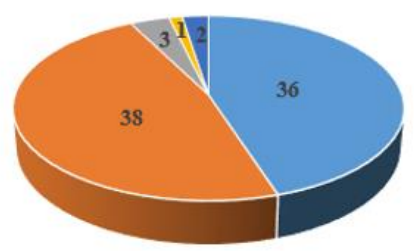

(b)
- 0 a 6 meses

- 6 a 12 meses

-12 a 18 meses

- 18 a 24 meses

- Acima de 24 meses

Figura 18. Tempo médio de duração dos projetos, agrupados por: (a) Compensação; (b) Cobrança Fonte: Elaborado a partir dos dados do SINFEHIDRO, 2017 
A Figura 18 traz que, independentemente do tipo de financiamento (cobrança ou compensação), a maior parte dos empreendimentos possui duração em torno dos 6 a 12 meses (144 projetos no total), e são raros os que duram acima de 24 meses (apenas 4 projetos). Como a maioria dos empreendimentos financiados são de curta duração, podemos concluir que, no período analisado, houve uma predominância de submissão de projetos voltados a estudos ou planos em detrimento a obras e serviços, uma vez que esses últimos, em tese, são mais prolongados e também exigem mais recursos.

\subsubsection{Distribuição dos Recursos por Abrangência Territorial}

Outro critério de análise utilizado foi quanto à abrangência territorial dos empreendimentos. Para realizar a classificação dos projetos, foi sugerido o seguinte agrupamento:

- Abrangência Municipal/Local: envolvendo um único município;

- Abrangência Regional: envolvendo mais de um município;

- UGRHI 10: toda a Bacia.

A Tabela 11 sintetiza a quantidade de projetos enquadrados de acordo com a sua abrangência, a partir da análise dos projetos financiados:

Tabela 11. Classificação dos Projetos Financiados quanto à abrangência territorial

\begin{tabular}{c|c|c}
\hline \hline Abrangência & Quantidade & Percentagem (\%) \\
\hline \hline Municipal & 223 & 85,4 \\
\hline Regional & 20 & 7,7 \\
\hline UGRHI 10 & 18 & 6,9 \\
\hline \hline TOTAL & 261 & 100 \\
\hline \hline
\end{tabular}

Fonte: Elaborado a partir dos dados do SINFEHIDRO, 2017

Verifica-se que a maioria dos projetos financiados são voltados à escala municipal e o maior segmento tomador (em número de projetos) é o município. Isso reduz a escala de ganhos trazidos pelos empreendimentos, ou seja, os benefícios tornam-se mais pontuais. O Plano ressalta justamente a necessidade de se privilegiar as ações mais 
articuladas, com impacto mais estratégico, em detrimento das ações efêmeras e com caráter mais localizado, quanto à população atingida.

\subsection{Considerações Finais do Capítulo}

Esse Capítulo mostrou o processo de seleção adotado pelo Comitê ao longo das suas gestões. Trata-se de um processo de hierarquização realizado anualmente a partir de pactos firmados entre os diversos atores e que são divulgados a partir de Deliberações. São atribuídas pontuações aos projetos encaminhados, de acordo com as suas características e de acordo com os anseios do Comitê para aquele determinado ano. Esse sistema de pontuação só foi implantado a partir de 2001; até então, as Deliberações só consideravam as áreas prioritárias para financiamento, e a escolha podia ser mais sujeita a subjetividades.

As questões voltadas ao tratamento de esgotos, à destinação final de resíduos sólidos e a programas voltados às áreas críticas a erosão foram as que mais possuíram destaque ao longo das gestões. Os projetos de capacitação e educação ambiental aos membros do Comitê também passaram a ter mais destaque.

Tomando como referência o processo de priorização adotado, foi possível analisar os projetos que foram encaminhados e financiados na Bacia, de modo a compreender se retrataram de fato as metas estipuladas no seu Plano.

No período analisado, o Comitê obteve a marca de 447 projetos encaminhados, porém, financiou apenas 261. Pelo que pudemos constatar, essa grande quantidade de projetos cancelados esteve atrelada à falta de documentação pertinente ao longo do processo ou à má qualidade dos projetos encaminhados, que não atenderam às exigências do Comitê.

Ao se analisar as características desses projetos encaminhados com relação às Metas estipuladas no Plano de Bacia, constatou-se que a maior parte foi voltado à Educação Ambiental, Coleta e Tratamento dos Esgotos, Destinação dos Resíduos Sólidos e Combate a Problemas de Erosão Urbana, o que está coerente com os anseios dos representantes do Comitê.

Quanto aos PDCs, que são Programas norteadores no âmbito estadual, os que obtiveram maior quantidade de projetos contemplados foram o 3 (Recuperação da Qualidade dos corpos d'água) e o 1 (Base de Dados, Cadastros, Estudos e 
Levantamentos). $\mathrm{O}$ enquadramento dos projetos a esses PDCs também está coerente com as metas estipuladas no Plano de Bacia.

Por fim, a partir de uma análise mais minuciosa do Plano, considerando as suas metas no âmbito do município, ou seja, levantando as metas estipuladas para cada município e os projetos que foram encaminhados e financiados, foi possível realizar as seguintes constatações: no que tange à coleta e ao tratamento de esgotos, a maior parte desses municípios mais deficitários foram contemplados com pelo menos 1 projeto financiado que refletia de fato as metas estipuladas no Plano; quanto aos projetos relacionados à destinação adequada dos resíduos sólidos, foi possível observar que eles possuíam relação direta com as metas, porém, os tomadores encontraram dificuldades na elaboração de projetos que atendessem aos requisitos exigidos e no fornecimento das documentações necessárias. Isso evidenciou um despreparo quanto à capacitação dos gestores, principalmente, no âmbito municipal, que foram os que mais solicitaram financiamento.

Para os casos de erosão na Bacia, foi constatada falta de projetos submetidos ao Comitê, o que fez com que não se atingisse a meta estipulada para os municípios mais suscetíveis. Já a meta relacionada à Educação Ambiental foi a área que mais obteve projetos reprovados, sendo que o principal solicitante foi a Sociedade Civil. Esse fato vai ao encontro do que foi discutido anteriormente, que uma alta rotatividade de instituições entre as gestões e de indivíduos entre as instituições, pode resultar em uma maior lacuna quanto ao entendimento, por esses atores, dos anseios do Comitê para algumas áreas fundamentais. O que pode impactar na qualidade dos projetos elaborados, e no número elevado de projetos cancelados. 


\section{Considerações Finais}

A análise dos critérios adotados pelo Comitê de Bacia Hidrográfica do Sorocaba e Médio Tietê para a distribuição dos recursos do FEHIDRO e dos 447 projetos encaminhados pelos três segmentos interessados (Estado, Município e Sociedade Civil), permitiu verificar os seguintes aspectos.

A priorização dos recursos foi fruto de consensos entre os participantes do Comitê, que definem anualmente quais áreas devem ser focadas. No início da implantação do Comitê, em 1995, o entendimento foi que deveriam ser considerados os projetos que tratassem da preservação e recuperação das áreas de mananciais. Nos anos subsequentes, além das áreas de mananciais, também passaram a ser definidos como prioridades de investimentos os empreendimentos voltados à coleta e tratamento de esgotos, à recuperação de áreas com erosão e os programas destinados à disposição adequada dos resíduos sólidos.

Ao todo foram encaminhados 447 projetos, sendo 289 oriundos da compensação financeira e 158 da cobrança pelo uso da água. Desses, 261 foram efetivamente financiados. Dos financiados, o segmento Município foi o maior tomador (66\%), seguido da Sociedade Civil (24\%) e do Estado (10\%). Quanto aos valores, foram financiados aproximadamente $\mathrm{R} \$ 60$ milhões para todo o período analisado.

A partir da análise dos primeiros projetos financiados com os recursos do FEHIDRO, constatou-se que a maior parte possuía como principal objetivo a recuperação das áreas de mananciais da bacia. Já na gestão 2001/2003, os projetos relacionados às principais fragilidades da Bacia (Recuperação dos Mananciais, Destinação adequada dos Resíduos Sólidos, Coleta e Tratamento de Esgoto e Erosão) continuaram a ser priorizados, porém, o Comitê passou a hierarquizar também empreendimentos na área de Educação e Capacitação Ambiental e Coleta Seletiva. Foram focados aqueles que possuíam abrangência regional, e de preferência com uma duração de até 6 meses para a sua conclusão.

Em 2008, com o advento do Plano de Bacia do Sorocaba e Médio Tietê, a priorização passou a ser em função das metas estabelecidas no Plano. As áreas que obtiveram mais projetos encaminhados para o Comitê foram aquelas relacionadas à Capacitação e Educação Ambiental (meta 14 do Plano de Bacia), seguidas de Sistema de Coleta e Tratamento de Esgoto (Metas 1 e 2 do Plano) e Destinação Adequada de 
Resíduos Sólidos (meta 3 do Plano). Esses dados mostram a preocupação do Comitê em financiar/priorizar os projetos que estavam diretamente relacionados às metas estabelecidas no seu Plano.

Ao considerar apenas os municípios prioritários, foi possível constatar que, no quesito coleta e tratamento de esgoto, a maior parte deles foram contemplados com pelo menos 1 projeto financiado de acordo com as metas estipuladas no Plano. Quanto aos relacionados à destinação adequada dos resíduos sólidos, foi possível observar que os solicitantes encontraram dificuldades na elaboração de bons projetos e no fornecimento das documentações exigidas, o que refletiu na quantidade elevada de empreendimentos cancelados. No quesito Erosão na Bacia, houve falta de empreendimentos submetidos ao Comitê relacionados aos municípios prioritários, fazendo com que as metas não tenham sido totalmente atingidas. Já, Educação Ambiental, foi a área que mais obteve projetos reprovados, sendo que o principal solicitante foi a Sociedade Civil.

Ao longo desse trabalho também foi realizada uma análise comparativa entre o segmento tomador e o tipo de projeto encaminhado. Foi possível concluir que, para os projetos de Educação Ambiental, a grande maioria, cerca de 75\%, foram elaborados pela Sociedade Civil. Ao confrontarmos os projetos encaminhados com os que foram efetivamente financiados, constatamos que o índice de cancelamento esteve na ordem de 40\%. Porém, quando tomamos apenas os da área de Educação Ambiental, esse índice passa dos $60 \%$.

Quanto à eficiência do processo de hierarquização do Comitê, foi possível concluir que, até a gestão 2000/2001, não havia a atribuição de pesos e pontuações para os projetos apresentados, o que podia dificultar a impessoalidade na hora da avaliação. A adoção de critérios cada vez mais técnicos e menos sujeitos a subjetividades só ocorreu com o advento do sistema de pontuações dado a cada critério, determinado previamente pelo Comitê. Já no quesito divulgação, foi possível concluir que houve preocupação por parte do Comitê em publicar todas as informações pertinentes aos projetos.

Com relação aos PDCs prioritários para investimento na Bacia, a maior quantidade foi enquadrada nos PDC 3 (recuperação da qualidade dos corpos de água) com 95 projetos financiados, PDC 1 (base de dados, cadastro, estudos e levantamento) com 88 e PDC 4 (conservação e proteção dos corpos d'água) com 26 projetos. O que demonstra que houve coerência entre os investimentos realizados e as ações a serem executadas de acordo com as metas prioritárias do Plano de Bacia, que estão relacionados 
à prevenção e contenção da erosão em áreas urbanas; à coleta e tratamento de esgoto e à destinação adequada dos Resíduos Sólidos Urbanos.

No que tange à abrangência territorial, podemos concluir que não houve uma relação direta entre os projetos financiados e as metas do Plano. A maioria dos empreendimentos financiados $(85,4 \%)$ foram categorizados como de abrangência municipal, tendo os municípios como principal tomador (66\%). Esses empreendimentos elaborados pelos Municípios são importantes, mas na maioria das vezes solucionam problemas mais locais enfrentados por esse segmento, não conseguindo, entretanto, trazer benefícios significativos na escala da bacia.

Por fim, foi possível concluir que a aprendizagem adquirida nos colegiados pode de fato impactar na postura adotada pelos atores no processo de tomada de decisão. A partir de um adequado processo de participação é possível incentivar uma constante troca de experiências entre os envolvidos. No caso do Comitê da Bacia Hidrográfica do Sorocaba e Médio Tietê, com a constatação dos principais problemas da Bacia, pelos vários atores participantes, foi possível perceber que houve uma maior compreensão das dificuldades existentes e uma possiblidade de intervenção mais direta sobre os diversos assuntos tratados.

Considerando então os resultados apontados até aqui nessa dissertação, sugere-se que sejam ponderados os seguintes temas para complementação em estudos posteriores:

- Elaboração de estudos dirigidos às entidades da Sociedade Civil com o intuito de tentar compreender melhor os motivos que levam ao alto índice de projetos cancelados/reprovados ao longo das gestões dos Comitês de Bacias Hidrográficas;

- Proposição de metodologias que objetivem tornar a distribuição dos recursos financeiros mais igualitária entre os três segmentos, de modo que não haja uma grande discrepância entre eles;

- Comparação dos critérios de seleção e priorização utilizados no Comitê do Sorocaba e Médio Tietê com os aplicados nos demais Comitês do estado de São Paulo, com o intuito de adequações e melhorias. 


\section{REFERÊNCIAS BIBLIOGRÁFICAS}

ALVIM, A. T. B. A Contribuição do Comitê do Alto Tietê à Gestão da Bacia Metropolitana. Tese (Doutorado em Arquitetura e Urbanismo) - Faculdade de Arquitetura e Urbanismo, Universidade de São Paulo, São Paulo, 2003.

ANA - Agência Nacional de Águas. A evolução da Gestão de Recursos Hídricos no Brasil. Brasília: ANA, 2002.

AZEVEDO, F. Z. Análise de Procedimentos de Gestão do Comitê de Bacia Hidrográfica do Rio São José dos Dourados para Implementação da Política de Recursos Hídricos no Estado de São Paulo. Universidade Federal de São Carlos, Programa de Pós-Graduação em Engenharia Urbana, São Carlos, 2009.

BARTH, F. T. Aspectos Institucionais do Gerenciamento de Recursos Hídricos. In: REBOUÇAS, A. C.; BRAGA, B.; TUNDISI, J. G. (Org.) Águas doces no Brasil: capital ecológico, uso e conservação. 2. ed. São Paulo: Escrituras, 2002. p. 563-97.

BARTH, F.T. Comitês de bacias hidrográficas e agências de água. In: SEMANA INTERNACIONAL DE ESTUDOS SOBRE GESTAO DE RECURSOS HIDRICOS. Foz do Iguaçu. Anais. Foz do Iguaçu, ABRH, 1999. 11p. (Anais virtuais).

BEllo, E. A.; VAlenCiO, N. F. L. S. Impactos da Política de Cobrança dos Recursos Hídricos sobre as Indústrias dos Municípios de São Carlos e Campinas. In: MARTINS; VALENCIO. (Org.). Uso e Gestão dos Recursos Hídricos no Brasil; desafios teóricos e político-institucionais. 1 ed. São Carlos: RiMa, 2003.

BERNAL, T. A. Plano de recursos hídricos como instrumento de planejamento ambiental: um estudo de caso na bacia do Sorocaba/Médio Tietê, SP. 2012. Dissertação (Mestrado em Ciências da Engenharia Ambiental) - Escola de Engenharia de São Carlos, University of São Paulo, São Carlos, 2012.

BERRETA, M. S. R.; LAURENT, F.; BASSO, L. A. Os princípios e fundamentos da legislação das águas na França. Boletim Gaúcho de Geografia,n. 39, p. 13- 24, jul. 2012.

BERRY, K.A.; Mollard, E. Social participation in water governance and management. London, UK: Earthscan, 2010. p.320.

BRASIL. Congresso Nacional. Constituição da República Federativa do Brasil de 1988. Brasília: Senado Federal: Centro Gráfico, 1988. 48p.

Lei n. 9.433, 8 jan. 1997. Institui a Politica Naciona1 de Recursos

Hídricos, cria o Sistema Nacional de Gerenciamento de Recursos Hídricos e da outras providencias. Diário Oficial da União. Brasília. 1997.

CAMPOS, J. D. Cobrança pelo uso da água nas transposições da bacia do rio Paraíba do Sul envolvendo o setor elétrico.2001. 192 p. Dissertação (Mestrado em Engenharia Civil) - COPPE/UFRJ, Universidade Federal do Rio de Janeiro, Rio de Janeiro, 2001. 
CAMPOS, V. N. O.; FRACALANZA, A. P. Governança das águas no brasil: conflitos pela apropriação da água e a busca da integração como consenso. Ambiente \& Sociedade. Campinas v. XIII, n. 2. p. 365-382. jul.-dez. 2010.

CAMPOS, V. N. O. O Comitê de Bacia Hidrográfica do Alto Tietê e o Consejo de Cuenca del Valle de México. 2008. Tese (Doutorado em Integração da América Latina) - Integração da América Latina, Universidade de São Paulo, São Paulo, 2008.

CARDOSO-SILVA, S.; FERREIRA, T.; POMPEO, M.L.M. Diretiva Quadro D’Água: uma revisão crítica e a possibilidade de aplicação ao Brasil. Ambient. soc. vol. 16 no. 1 São Paulo Jan/Mar. 2013.

CARTER, J.; HOWE, J. The water framework directive and the strategic environmental assessment directive: exploring the linkages. Environmental Impact Assessment Review, n. 26, p. 287-300, 2006.

CARVAlHO, G. B. B. et al. Avaliação da Situação dos Fundos Estaduais de Recursos. Hídricos. In: Simpósio Brasileiro de Recursos Hídricos, Rio Grande do Sul, 2009.

CARVAlho, J. L. Governança da água no Estado de São Paulo estudo de caso: Comitê de Bacias Hidrográficas dos rios Sorocaba e Médio Tietê. Tese (Doutorado em Ciência Ambiental) - Programa de Pós-Graduação em Ciência Ambiental da Universidade de São Paulo, São Paulo, 2011.

CASTRO, C.N. Gestão das águas: experiências internacional e brasileira. Textos para discussão, n. 1477. Brasília: IPEA, 2012.

CBH-BS. Fundamentos da Cobrança pelo Uso dos Recursos Hídricos na Bacia Hidrográfica da Baixada Santista, 2009.

CBH-SMT, 2016. Comitê de Bacias Hidrográficas dos Rios Sorocaba e Médio Tietê. Relatório de Situação, $2016 . \quad$ Disponível em http://www.sigrh.sp.gov.br/relatoriosituacaorecursoshidricos. Acessado em setembro de 2017.

CIS - Common Implementation Strategy For The Water Framework Directive $(2000 / 60 / E C)$. Guidance Document $n^{\circ}$. Monitoring under the Water Framework Directive. 153p. 2003.

COIMBRA, R., ROCHA, C.L., BEEKMAN, G.B. Recursos hídricos: conceitos, desafios e capacitação. Brasília, DF.: ANEEL, 1999. 78p.

COLLINS, A. et al. Implementing the water framework directive: a transition from established monitoring networks in England and Wales. Environmental Science \& Policy, n. 17, p. 49-61, 2012.

CORREIA, F. N. Algumas reflexões sobre os mecanismos de gestão de recursos hídricos e a experiência da União Europeia. REGA, vol. 2, n. 2, p. 5-16. 2005. 
DAEE - DEPARTAMENTO DE ÁGUAS E ENERGIA ELÉTRICA. Elaboração do Plano Estadual de Recursos Hídricos, seu Programa de Investimentos e a Regulamentação da Cobrança pelo Uso dos Recursos Hídricos, do Estado de São Paulo. Relatório Síntese, 2005.

DECLARAÇÃO DE DUBLIN. Disponível em http://www.meioambiente.uerj.br/emrevista/documentos/dublin.htm. Acessado em: agosto de 2017.

DE STEFANO, L. Facing the Water Framework Directive Challenges: a baseline of stakeholder participation in the European Union. J. Environ. Manag. 91p. 2010.

EC, 2000. Directive of the European Parliament and of the Council 2000/60/EC Establishing a Framework for Community Action in the Field of Water Policy. Official Journal 2000 L 327/1. European Commission, Brussels, 2000.

FERNANDES. A. M. Características Hidrogeoquímicas da bacia de drenagem do rio Sorocaba, SP: processos erosivos mecânicos e químicos. Tese de Doutorado, USP, Química na Agricultura e no Ambiente, 2012.

FERREIRA, J.; SCHMIDT, L. Crise económica e (in)cumprimento da Directiva Quadro da Água. VIII Congresso Português de Sociologia. 2014.

FRACALANZA, A.P. Crise de governança da água na Região Metropolitana de São Paulo: (re)centralização da gestão e injustiça ambiental. São Paulo, 2016. Tese (Livre docência em Gestão de água, conflitos e políticas ambientais no Brasil) - Escola de Artes, Ciências e Humanidades, Universidade de São Paulo. 154p.

FREITAS, A. J. Gestão de recursos hídricos. In: Gestão de recursos hídricos: aspectos legais, econômicos e administrativos e sociais. Brasília/DF: SRH/UFV/ABRH, 2001.

FREITAS, N. P.; MARANGON, S. H. O comitê de Bacias Hidrográficas do Rio Sorocaba e Médio Tietê. In: Simpósio Internacional sobre Gestão de Recursos Hídricos. Gramado/RS, 1998.

FREITAS, S. S. Análise sobre a discussão para implementação da cobrança pelo uso da água: desafios da gestão participativa no Comitê da Bacia Hidrográfica do Alto Tietê, 2014. 149f. Dissertação (Mestrado). Universidade de São Paulo, São Paulo, 2013.

FUNDAÇÃO SEADE. Fundação Sistema Estadual de Análise de Dados. Disponível em: http://www.seade.gov.br/analises_estudos. Acessado em outubro de 2017.

FUNDO ESTADUAL DE RECURSOS HÍDRICOS (FEHIDRO). Conselho de Orientação do Fundo Estadual de Recursos Hídricos (COFEHIDRO). Manual de Procedimentos Operacionais para Investimentos. 2015. Disponível em http://fehidro.sigrh.sp.gov.br/fehidro/gerais/sigrh/ManualDeProcedimentosOperac ionaisParaInvestimento2015.pdf. Acessado em março de 2018. 
FURNIVAL, A. C.; COSTA, L; S.; Informação Ambiental e Práticas Culturais de Comunicação para o Desenvolvimento Sustentável. In: Uso e Gestão dos Recursos Hídricos no Brasil: desafios teóricos e político-institucionais / organizado por Rodrigo Constante Martins e Norma Felicidade Lopes da Silva Valencio - São Carlos: RiMa, 2003.

GANZELI, J. P. A Política Estadual de Recursos Hídricos (Lei 7.663 -1991). In: SÃO PAULO (Estado). Política e Gestão de Recursos Hídricos no Estado de São Paulo. 1993. $111 \mathrm{p}$.

GARCIA, A. C. M. C.; VALENCIO, N. F. L. S. Gestão de Recursos Hídricos no Estado de São Paulo: Obstáculos Técnicos e Políticos à Sustentabilidade das Práticas Decisórias em Comitês de Bacias. In: MARTINS; VALENCIO. (Org.). Uso e Gestão dos Recursos Hídricos no Brasil; desafios teóricos e político-institucionais. 1 ed. São Carlos: RiMa, 2003, v. II, p. 271-293

GOHN, M. G. Teoria dos Movimentos Sociais: Paradigmas Clássicos e Contemporâneos. $7^{\mathrm{a}}$ ed. São Paulo: Edições Loyola, 2007.

GOMES, J. L., BARBIERI, J. C. Gerenciamento de recursos hídricos no Brasil e no Estado de São Paulo: um novo modelo de política pública. Cad. EBAPE.BR, Rio de Janeiro, v.2, n.3, p.01-21, Dec. 2004.

GRANZIERA, M. L. M. Direito de águas: disciplina jurídica das águas doces. São Paulo: Atlas, 2014.

GUIMARÃES, P. B. V. Direito de Águas Doces no Poder Judiciário: Perspectivas de Análise na Judicialização do Direito de Águas. Campo Jurídico, vol. 3, n. 1, p. 83-123, 2015.

HESPANHOL, I. Um novo paradigma para a gestão de recursos hídricos. Revista de Estudos Avançados, São Paulo, v. 22, n. 63, 2008, p. 131 - 158.

IPT. INSTITUTO DE PESQUISAS TECNOLÓGICAS - IPT. Plano de Bacia da Unidade de Gerenciamento de Recursos Hídricos do Sorocaba e Médio Tietê (UGRHI 10). São Paulo, 2008. 352 p.

JACOBI, P.R.; FRACALANZA, A.P.; EMPINOTTI, V.; SOUZA, A.N. Governança Ambiental. In: Tercio Ambrizzi; Pedro Roberto Jacobi; Lívia Márcia Mosso Dutra. (Org). Ciência das Mudanças Climáticas e sua Interdisciplinaridade. 1 ed. São Paulo: Annablume Editora, 2015, v.1, p. 260-281.

JACOBI, P.R.; FREITAS, S. S.; FRACALANZA, A. P. Políticas Públicas, aprendizagem social e gestão dos recursos hídricos. In: Prefeitura Municipal de Santo André. (Org). Memórias do Seminário: Educação Ambiental na Gestão e Conservação dos Recursos Hídricos - compartilhando saberes e práticas. 1 ed. São Paulo: SGRNPPA/GEEA, 2014, v.1, p. 36-42. 
JACOBI, P. R. Governança da água no Brasil. In: RIBEIRO, Wagner Costa (Org.). Governança da água no Brasil: uma visão interdisciplinar. São Paulo: Annablume/FAPESP/CNPq, 2009.

KELMAN, J. Gerenciamento de Recursos Hídricos: Parte I - Outorga. In: Simpósio Brasileiro de Recursos Hídricos. Vitória. Anais. ABRH, 1997.

KOCHSKAMPER, E.; et al. Participation for effective environmental governance? Evidence from Water Framework Directive implementation in Germany, Spain and the United Kingdom. J. Environ. Manag. p.737-748, 2016.

LANNA, A.E.L., DORFMANN, R. Sistemas de gerenciamento de recursos hídricos: críticas a algumas propostas. Administração Pública, Rio de Janeiro, v.27, n.2, p.63-73, abr./jun., 1993.

LANNA, A.E.L. Gerenciamento de bacia hidrográfica: aspectos conceituais e metodológicos. Brasília, DF.: IBAMA, 1995b. 171p. (Coleção Meio Ambiente).

LEAL, A. C. Gestão das águas no Pontal do Paranapanema - SP. (Tese de Doutorado). Campinas: Instituto de Geociências/UNICAMP, 2000.

MACHADO, C. J. S. A gestão francesa de recursos hídricos: descrição e análise dos princípios jurídicos. Revista Brasileira de Recursos Hídricos, v. 8, n. 4, p. 31-47, 2003.

MARTINS, R. G. Análise dos Critérios de Priorização de Projetos Junto ao Fundo Estadual de Recursos Hídricos do Estado de São Paulo: Estudo de Caso do Comitê da Bacia Hidrográfica do Tietê-Jacaré. Dissertação (Mestrado). Universidade Federal de São Carlos - UFSCAR, São Carlos, 2012.

MÉRIDIANES GEO. Disponível em: https://meridianes.org/2014/09/14/france-lapolitique-de-leau-a-50-ans-bilan. Acessado em agosto de 2017.

MILARÉ, Édis. Direito do Ambiente: doutrina, jurisprudência, glossário. 3 ed. ver., atual. e ampl. - São Paulo: Editora Revista dos Tribunais, 2004.

MORENO JUNIOR, I. Uma Experiência de Gestão de Recursos Hídricos: A Implantação de uma Proposta para o Estado do Rio de Janeiro. Dissertação (Mestrado em Engenharia). Universidade Federal do Rio de Janeiro, RJ, 2006.

MOTTA, R. S. Utilização de critérios econômicos para a valorização da água no Brasil. Rio de Janeiro: Ipea, 1998. (Texto para Discussão, n. 556).

PARENTE, Kátia Simões. O Sistema Integrado de Gerenciamento de Recursos Hídricos no Comitê de Bacia Hidrográfica do Tietê-Jacaré. Tese (Doutorado em Saúde Pública) - Universidade de São Paulo, São Paulo 2007.

PEREIRA, J. S. A Cobrança Pelo Uso da Água Como Instrumento de Gestão dos Recursos Hídricos: Da Experiência Francesa à Prática Brasileira. Tese (Doutorado em Engenharia) - Universidade Federal do Rio Grande do Sul, 2002. 
PINHATTI, A. L. Aspectos conceituais da gestão de recursos hídricos e suas aplicações no caso das bacias hidrográficas dos rios Piracicaba, Capivari e Jundiaí, SP. Dissertação (Mestrado) - Instituto de Geociências, Universidade Estadual de Campinas - UNICAMP, Campinas, 1998.

POMPEU, Cid Tomanik. Direito de águas no Brasil. São Paulo: Editora Revista dos Tribunais, 2006.

PORTO, M.F.A., PORTO, R.L., Gestão de Bacias Hidrográficas, Estudos Avançados. ISSN, São Paulo, 2008.

RAMOS, M. Gestão de Recursos Hídricos e Cobrança pelo Uso da Água. Escola Brasileira de Administração Pública, Fundação Getúlio Vargas, 2007.

RODRIGUES, R. G. Fundo Estadual de Recursos Hídricos do Rio de Janeiro: Diagnóstico do seu Funcionamento e Desafios. Dissertação de Mestrado, Universidade Federal do Rio de Janeiro, Programa de Pós-Graduação de Engenharia, Rio de Janeiro, 2007.

SANTOS, M. O. R. M. O impacto da cobrança pelo uso da água no comportamento do usuário. Tese de Doutorado, UFRJ, Programa de Pós-Graduação em Ciências em Engenharia Civil, 2002.

SILVA, L. M. Gestão Ambiental de Recursos Hídricos: Pressupostos Básicos, Conceitos, Modelos e Instrumentos. Programa de Pós-Graduação em Geografia, Universidade Federal de Uberlândia, 2010.

SÃO PAULO. Conselho Estadual de Recursos Hídricos. Plano Estadual de Recursos Hídricos: 2012/2015 $1^{\text {a }}$ ed. São Paulo, DAEE, 2014.

. Conselho Estadual de Recursos Hídricos. Plano Estadual de Recursos Hídricos: 2004/2007 Resumo. São Paulo, DAEE, 2006.

. Constituição Estadual do Estado de São Paulo, 1989.

Deliberação CBH-SMT no 249 de 10 de dezembro de 2010. Define cronograma de atividades, diretrizes e critérios gerais para hierarquização de empreendimentos para obtenção de financiamento com recursos do Fehidro destinados à área do CBH-SMT, referentes ao orçamento 2011 e da arrecadação da cobrança nos exercícios 2010/2011 e dá outras providências.

. Deliberação CBH-SMT no 253, de 30 de março de 2011. Empossa o corpo diretivo do CBH-SMT, representantes dos órgãos governamentais, da sociedade civil e dos municípios nos Plenários do CBH-SMT, para o mandato 2011 a 2013.

Deliberação CBH-SMT no 265, de 8 de dezembro de 2011. Define cronograma de atividades, diretrizes e critérios gerais para hierarquização de empreendimentos para obtenção de financiamento com recursos do Fehidro 2012 e dá outras providências. 
Deliberação CBH-SMT 273 de 21 de junho de 2012. Define cronograma de atividades, diretrizes e critérios gerais para hierarquização de empreendimentos para obtenção de financiamento com os recursos não utilizados do Fehidro 2012 e dá outras providências.

- Deliberação CBH-SMT no 295, de 22 de março de 2013. Empossa o corpo diretivo do CBH-SMT, representantes dos órgãos governamentais, da sociedade civil e dos municípios nos Plenários do CBH-SMT, para o mandato 2013 a 2015.

Deliberação CBH-SMT 307 de 13 de dezembro de 2013. Define cronograma de atividades, diretrizes e critérios gerais para hierarquização de empreendimentos para obtenção de financiamento com recursos do Fehidro 2014 e dá outras providências.

. Deliberação CBH-SMT no 342, de 11 de dezembro de 2015. Define cronograma de atividades, diretrizes e critérios gerais para hierarquização de empreendimentos para obtenção de financiamento com recursos do Fehidro 2016 e dá outras providências.

Deliberação CBH-SMT no 355, de 20 de dezembro de 2016. Define cronograma de atividades, diretrizes e critérios gerais para hierarquização de empreendimentos para obtenção de financiamento com recursos do Fehidro 2017

Deliberação CRH $n^{\circ} 146$, de 11 de dezembro de 2012. Aprova os critérios, os prazos e os procedimentos para a elaboração do Plano de Bacia Hidrográfica e do Relatório de Situação dos Recursos Hídricos da Bacia Hidrográfica, 2012.

Lei n. ${ }^{\circ}$ 7.663, de 30 de dezembro de 1991. Estabelece Normas de Orientação à Política Estadual de Recursos Hídricos bem como ao Sistema Integrado de Gerenciamento de Recursos Hídricos, 1991.

Lei n. ${ }^{\circ} 10.020$, de 3 de julho de 1998. Autoriza o Poder Executivo a participar da constituição de Fundações Agências de Bacias Hidrográficas dirigidas aos corpos de água superficiais e subterrâneos de domínio do Estado de São Paulo e dá outras providências correlatas, 1998.

Lei $\mathrm{n}^{\circ} 12.183$, de 29 dezembro de 2005. Dispõe sobre a cobrança pela utilização dos recursos hídricos do domínio do Estado de São Paulo, os procedimentos para fixação dos seus limites, condicionantes e valores e dá outras providências, 2005.

Lei $\mathrm{n}^{\circ} 16.337$, de 14 de dezembro de 2016. Dispõe sobre o Plano Estadual de Recursos Hídricos - PERH e dá providências correlatas, 2016.

Portaria DAEE $n^{\circ} 1.630$, de 30 de maio de 2017. Dispõe sobre procedimentos de natureza técnica e administrativa para obtenção de manifestação e outorga de direito de uso e de interferência em recursos hídricos de domínio do Estado de São Paulo, 2017. 
SETTI, ARNALDO AUGUSTO; LIMA, JORGE ENOCH FURQUIM WERNECK, et. al. Introdução ao gerenciamento de Recurso Hídricos no Brasil. $2^{\mathrm{a}}$ ed. Brasília: Agência Nacional de Energia Elétrica, Superintendência de Estudos e Informações Hidrológicas, p. 207, 2000.

SIGRH - Sistema de Informação para o Gerenciamento de Recursos Hídricos para o Estado de São Paulo. Disponível em: http://www.sigrh.sp.gov.br. Acessado em maio de 2017.

SOUSA E. S; et al. DIREITO DE ACESSO À ÁGUA: UM ESTUDO SOBRE A OUTORGA DOS RECURSOS HÍDRICOS. In. Revista Gestão \& Conhecimento. Poços de Caldas, 2006.

THOMAS, P. T. Proposta de uma metodologia de cobrança pelo uso da água vinculada à escassez. Dissertação de Mestrado, COPPE/UFRJ, Engenharia Civil, Rio de Janeiro, 2002.

VERA, L. H. A. Atuação da Cobrança pelo Uso da Água de Domínio da União como Instrumento de Gestão de Recursos Hídricos na Bacia Hidrográfica do Rio São Francisco. Dissertação de Mestrado, Universidade Federal de Pernambuco, Programa de Pós-Graduação em Engenharia Civil, Tecnologia Ambiental e Recursos Hídricos, Pernambuco, 2014.

YASSUDA, E. R. Gestão de Recursos Hídricos: Fundamentos e Aspectos Institucionais. Revista Adm. pub., v. 9, n. 27, p. 5-18, 1993. 
ANEXO 1. Caracterização dos Programas de Duração Continuada do PERH-1994/1995.

Quadro 8 Programas de Duração Continuada (PDC) 1 do PERH 1994/1995

PDC 1: PLANEJAMENTO E GERENCIAMENTO DE RECURSOS HÍDRICOS PGRH

\begin{tabular}{|c|c|}
\hline Sub-Programas & Ação \\
\hline Planejamento & $\begin{array}{l}\text { Elaboração, avaliação e controle do plano } \\
\text { quadrienal de recursos hídricos e dos planos } \\
\text { de bacias hidrográficas. Elaboração e } \\
\text { publicação do relatório de situação dos } \\
\text { recursos hídricos no Estado de São Paulo. }\end{array}$ \\
\hline Gerenciamento & $\begin{array}{l}\text { Organização, implantação e apoio técnico e } \\
\text { administrativo aos comitês de bacias } \\
\text { hidrográficas. Desenvolvimento, } \\
\text { regulamentação e aplicação dos instrumentos } \\
\text { de gerenciamento dos recursos hídricos: } \\
\text { cadastro, outorga e cobrança. Promoção e } \\
\text { criação de associações de usuários de } \\
\text { recursos hídricos. } \\
\end{array}$ \\
\hline $\begin{array}{c}\text { Sistema de Informações Sobre Recursos } \\
\text { Hídricos }\end{array}$ & $\begin{array}{c}\text { Desenvolvimento e gestão do banco de dado } \\
\text { hidrológicos. Projeto, implantação e gestão } \\
\text { do sistema de cadastro, outorga e cobrança. } \\
\text { Projeto, implantação e gestão do sistema de } \\
\text { planejamento, avaliação e controle. Projeto, } \\
\text { implantação e gestão do sistema de } \\
\text { informações aos usuários e públicos. Projeto, } \\
\text { implantação e gestão de sistema de } \\
\text { informaçôes ambientais sobre recursos } \\
\text { hídricos. }\end{array}$ \\
\hline Renovação da Rede Hidrológica & $\begin{array}{l}\text { Desenvolvimento, modernização, operação e } \\
\text { manutenção da rede hidrológica, } \\
\text { hidrometeorológica, sedimentométrica e } \\
\text { piezométrica. Implantação e operação de } \\
\text { sistemas de alerta, radares meteorológicos, } \\
\text { redes telemétricas, sensoriamento remoto e } \\
\text { imagens de satélite. Monitoramento da } \\
\text { qualidade e quantidade dos recursos hídricos. } \\
\text { Análise, processamento, publicação, } \\
\text { divulgação e difusão de dados hidrológicos. }\end{array}$ \\
\hline $\begin{array}{c}\text { Tecnologia e Treinamento em Recursos } \\
\text { Hídricos }\end{array}$ & $\begin{array}{l}\text { Desenvolvimento de cursos de } \\
\text { aperfeiçoamento e especialização em } \\
\text { recursos hídricos. Desenvolvimento de } \\
\text { estudos e pesquisas em recursos hídricos. } \\
\text { Programas de desenvolvimento institucional } \\
\text { e gerencial e de valorização profissional. } \\
\text { Programas de comunicação social e } \\
\text { divulgação. Cooperação e intercâmbio } \\
\text { técnico nacional e internacional. }\end{array}$ \\
\hline
\end{tabular}


Quadro 9. Programas de Duração Continuada (PDC) 2 do PERH 1994/1995

\begin{tabular}{|c|c|}
\hline \multicolumn{2}{|c|}{ PDC 2: APROVEITAMENTO MÚLTIPLO E CONTROLE DOS RECURSOS } \\
HÍDRICOS - PMAR
\end{tabular}

Fonte: SÃO PAULO, 1994

Quadro 10. Programas de Duração Continuada (PDC) 3 do PERH 1994/1995

\begin{tabular}{|c|c|}
\hline \multicolumn{2}{|c|}{$\begin{array}{l}\text { PDC 3: SERVIÇOS E OBRAS DE CONSERVAÇÃO, PROTEÇÃO E } \\
\text { RECUPERAÇÃO DA QUALIDADE DOS RECURSOS HÍDRICOS - PQRH }\end{array}$} \\
\hline Sub-Programas & Ação \\
\hline Tratamento de Esgotos Urbanos & $\begin{array}{l}\text { Estudos e projetos de obras de coleta, } \\
\text { interceptação, tratamento e disposição de } \\
\text { esgotos urbanos. Obras e serviços de } \\
\text { sistemas de coleta e tratamento de esgotos } \\
\text { urbanos. Sistemas de avaliação e controle de } \\
\text { resultados de operação e manutenção de } \\
\text { sistemas de tratamento. }\end{array}$ \\
\hline Tratamento de Efluentes Industriais & $\begin{array}{l}\text { Cadastramento e caracterização das fontes } \\
\text { poluidoras industriais. Alternativas de } \\
\text { financiamento de sistemas de tratamento de } \\
\text { efluentes industriais. }\end{array}$ \\
\hline $\begin{array}{l}\text { Fiscalização e Monitoramento de Fontes } \\
\text { Industriais de Poluição das Águas }\end{array}$ & $\begin{array}{l}\text { Licenciamento, fiscalização e monitoramento } \\
\text { das fontes industriais de poluição das águas. }\end{array}$ \\
\hline $\begin{array}{l}\text { Controle das Fontes Difusas de Poluição das } \\
\text { Águas. }\end{array}$ & $\begin{array}{c}\text { Estudo, avaliação e controle das fontes } \\
\text { difusas de poluição das águas, considerando } \\
\text { atividades agrícolas e urbanas. }\end{array}$ \\
\hline
\end{tabular}


Quadro 11. Programas de Duração Continuada (PDC) 4 do PERH 1994/1995

\begin{tabular}{|c|c|}
\hline \multicolumn{2}{|c|}{ PDC 4: DESENV OLVIMENTO E PROTEÇÃO DAS ÁGUAS SUBTERRÂNEAS - } \\
PDAS
\end{tabular}

Fonte: SÂO PAULO, 1994

Quadro 12. Programas de Duração Continuada (PDC) 5 do PERH 1994/1995

\begin{tabular}{|c|c|}
\hline \multicolumn{2}{|c|}{ PDC 5: CONSERVAÇ̃̃O E PROTEÇÃO DOS MANANCIAIS SUPERFICIAIS DE } \\
ABATECIMENTO URBANO - PRMS \\
\hline \hline Sub-Programas & Ação \\
\hline $\begin{array}{c}\text { Identificação e Proteção dos Mananciais de } \\
\text { Águas Superficiais para Abastecimento } \\
\text { Urbano }\end{array}$ & $\begin{array}{c}\text { Levantamento dos sistemas urbanos de } \\
\text { abastecimento de água e dos mananciais de } \\
\text { águas superficiais. Estudo das alternativas } \\
\text { futuras para suprimento de água para } \\
\text { abastecimento urbano. Desenvolvimento de } \\
\text { legislação de proteção de mananciais de } \\
\text { águas superficiais. }\end{array}$ \\
$\begin{array}{c}\text { Racionalização do Uso do Recurso Hídrico } \\
\text { para Abastecimento Urbano }\end{array}$ & $\begin{array}{c}\text { Redução das perdas e desperdícios nos } \\
\text { Promoção da aplicação de equipamentos } \\
\text { hidráulicos e de saneamento que }\end{array}$ \\
$\begin{array}{c}\text { Cooperação com os Municípios para o } \\
\text { proporcionem economia de recursos hídricos } \\
\text { de Águas Superficiais para Abastecimento } \\
\text { Urbano }\end{array}$ & $\begin{array}{c}\text { Implantação e aplicação de legislação de } \\
\text { proteção de mananciais. Delegação aos } \\
\text { municípios para a gestão de águas de } \\
\text { interesse local com fins prioritários de } \\
\text { abastecimento urbano. }\end{array}$ \\
\hline
\end{tabular}


Quadro 13. Programas de Duração Continuada (PDC) 6 do PERH 1994/1995

\begin{tabular}{|c|c|}
\hline \multicolumn{2}{|c|}{ PDC 6: DESENVOLVIMENTO RACIONAL DA IRRIGAÇÃO - PDRI } \\
\hline \hline \multicolumn{2}{|c|}{ Aub-Progão } \\
\hline Disciplinamento da Utilização da Água para \\
Irrigação & $\begin{array}{c}\text { Cadastramento de irrigantes e regularização } \\
\text { das captaçães de águas superficiais e } \\
\text { subterrâneas. Zoneamento hidroagrícola, com } \\
\text { indicação das áreas de aptidão para irrigação. } \\
\text { Gerenciamento de recursos hídricos em áreas } \\
\text { críticas, com participação dos irrigantes. }\end{array}$ \\
\hline Racionalização do Uso da Água para & $\begin{array}{c}\text { Determinação regional dos valores de } \\
\text { consumo das principais culturas irrigáveis, } \\
\text { levando este conhecimento aos agricultores } \\
\text { visando aumentar a eficiência no uso da água } \\
\text { para irrigação. }\end{array}$ \\
\hline $\begin{array}{c}\text { Monitoramento de Áreas Irrigadas } \\
\text { Obras e Serviços de Sistemas Coletivos de } \\
\text { Irrigação e Drenagem }\end{array}$ & $\begin{array}{c}\text { Acompanhamento da evolução física das } \\
\text { áreas irrigadas através de sensoriamento } \\
\text { remoto, confrontando com o disciplinamento } \\
\text { da utilização da água para irrigação. }\end{array}$ \\
\hline $\begin{array}{c}\text { Estudos, levantamentos, projetos e obras de } \\
\text { sistemas coletivos de irrigação e drenagem, } \\
\text { com participação dos irrigantes e de suas } \\
\text { associações. }\end{array}$ \\
\hline
\end{tabular}

Fonte: SÃO PAULO, 1994

Quadro 14. Programas de Duração Continuada (PDC) 7 do PERH 1994/1995

PDC 7: CONSERVAÇÃO DE RECURSOS HÍDRICOS NA INDÚSTRIA - PCRI

\begin{tabular}{|c|c|}
\hline Sub-Programas & Ação \\
\hline Orientação à Localização Industrial & $\begin{array}{c}\text { Difusão de informações sobre as } \\
\text { disponibilidades hídricas,superficiais e } \\
\text { subterrâneas, e sobre o enquadramento dos } \\
\text { corpos receptores. }\end{array}$ \\
\hline $\begin{array}{c}\text { Racionalização do Uso do Recurso Hídrico } \\
\text { na Industria }\end{array}$ & $\begin{array}{c}\text { Promoção do uso racional das águas nas } \\
\text { atividades industriais, com o reuso e a } \\
\text { recirculação. Promoção da utilização de } \\
\text { equipamentos e processos que proporcionem } \\
\text { economia de água. }\end{array}$ \\
\hline $\begin{array}{c}\text { Disciplinamento do Uso da Água para fins } \\
\text { Industriais }\end{array}$ & $\begin{array}{c}\text { Cadastramento da utilização da água para } \\
\text { fins industriais e regularização das captações. }\end{array}$ \\
\hline
\end{tabular}


Quadro 15. Programas de Duração Continuada (PDC) 8 do PERH 1994/1995

\begin{tabular}{|c|c|}
\hline \multicolumn{2}{|c|}{ PDC 8: PREVENÇÃo E DEFESA CONTRA INUNDAÇÕES - PPDI } \\
\hline \hline Sub-Programas & Ação \\
\hline $\begin{array}{c}\text { Implantação de Medidas Estruturais de } \\
\text { Prevenção e Defesa Contra Inundações }\end{array}$ & $\begin{array}{c}\text { Estudos, projetos, serviços e obras de } \\
\text { desassoreamento, retificação e canalização de } \\
\text { cursos d'água. }\end{array}$ \\
\hline $\begin{array}{c}\text { Implantação de Medidas não Estruturais de } \\
\text { Prevenção e Defesa Contra Inundações }\end{array}$ & $\begin{array}{c}\text { Cadastramento de áreas inundáveis. } \\
\text { Zoneamento de áreas inundáveis. }\end{array}$ \\
\hline $\begin{array}{c}\text { Cooperação Com os Municípios para } \\
\text { Serviços e Obras de Prevenção e Defesa } \\
\text { Contra Inundações }\end{array}$ & $\begin{array}{c}\text { Convênios com os municípios para estudos, } \\
\text { projetos, serviços e obras de controle de } \\
\text { cheias e defesa contra inundações. } \\
\text { Assistência e cooperação aos municípios para } \\
\text { a implantação de medidas não estruturais de } \\
\text { prevenção de inundações. }\end{array}$ \\
\hline \multicolumn{2}{|c|}{} \\
\hline
\end{tabular}

Fonte: SÃO PAULO, 1994

Quadro 16. Programas de Duração Continuada (PDC) 9 do PERH 1994/1995

\begin{tabular}{|c|c|}
\hline \multicolumn{2}{|c|}{$\begin{array}{c}\text { PDC 9: PREVENÇÃO E DEFESA CONTRA A EROSÃO DO SOLO E O } \\
\text { ASSOREAMENTO DOS CORPOS D'ÁGUA - PPDE } \\
\end{array}$} \\
\hline Sub-Programas & Ação \\
\hline $\begin{array}{l}\text { Reflorestamento e Recomposição da } \\
\text { Vegetação Ciliar }\end{array}$ & $\begin{array}{l}\text { Produção de mudas e promoção do } \\
\text { reflorestamento ciliar e de topos de morros. } \\
\text { Incentivos e promoção do reflorestamento. }\end{array}$ \\
\hline $\begin{array}{l}\text { Desenvolvimento de Diagnóstico, Diretrizes } \\
\text { e Tecnologia para a Extração de Areias e } \\
\text { Outros Materiais de Construção }\end{array}$ & $\begin{array}{l}\text { Estudos e levantamentos para orientação e } \\
\text { controle da explotação de areia e outros } \\
\text { recursos minerais nos leitos, margens e } \\
\text { várzeas dos cursos d'água. }\end{array}$ \\
\hline $\begin{array}{c}\text { Cooperação com os Municípios em Serviços } \\
\text { e Obras de Prevenção e Defesa Contra a } \\
\text { Erosão Do Solo }\end{array}$ & $\begin{array}{l}\text { Convênios com os municípios para estudos, } \\
\text { projetos, serviços e obras de prevenção e } \\
\text { defesa contra a erosão do solo urbano e rural } \\
\text { e o assoreamento dos corpos d'água. } \\
\text { Assistência e orientação aos municípios para } \\
\text { o controle de extração de areia e outros } \\
\text { materiais de construção. }\end{array}$ \\
\hline
\end{tabular}

Fonte: SÃO PAULO, 1994 
Quadro 17. Programas de Duração Continuada (PDC) 10 do PERH 1994/1995

\begin{tabular}{|c|c|}
\hline \multicolumn{2}{|c|}{ PDC 10: DESENVOLVIMENTO DOS MUNICÍPIOS AFETADOS POR } \\
RESERVATÓRIOS E LEIS DE PROTEÇÃO DE MANANCIAIS - PDMA \\
\hline \hline Sub-Programas & Ação \\
\hline $\begin{array}{c}\text { Desenvolvimento da Utilização Múltipla dos } \\
\text { Reservatórios }\end{array}$ & $\begin{array}{c}\text { Projetos complementares para implantação } \\
\text { de infraestrutura para utilização dos } \\
\text { reservatórios para recreação, esportes } \\
\text { náuticos, turismo e pesca amadora. Projetos } \\
\text { complementares para implantação de } \\
\text { sistemas coletivos de irrigação e drenagem. }\end{array}$ \\
\hline $\begin{array}{c}\text { Desenvolvimento de Diagnóstico, Diretrizes } \\
\text { e Tecnologia para a Extração de Areias e } \\
\text { Outros Materiais de Construção }\end{array}$ & $\begin{array}{c}\text { Desenvolvimento de Projetos, Serviços e } \\
\text { Obras de Saneamento Básico. }\end{array}$ \\
\hline $\begin{array}{c}\text { Programas Complementares de Proteção e } \\
\text { Recuperação Ambiental }\end{array}$ & $\begin{array}{c}\text { Implantação e manutenção de áreas de } \\
\text { proteção e conservação ambiental. }\end{array}$ \\
\hline
\end{tabular}

Fonte: S⿱艹AOO PAULO, 1994

Quadro 18. Programas de Duração Continuada (PDC) 11 do PERH 1994/1995

PDC 11: ARTICULAÇÃO INTERESTADUAL E COM A UNIÃO - PAIU

\begin{tabular}{|c|c|}
\hline \hline Sub-Programas & Ação \\
\hline \hline & $\begin{array}{c}\text { Cooperação com os Estados e a União com } \\
\text { vistas o planejamento e gerenciamento dos } \\
\text { recursos hídricos em bacias de rios de } \\
\text { domínio Federal. }\end{array}$ \\
\hline
\end{tabular}

Fonte: SÃO PAULO, 1994

Quadro 19. Programas de Duração Continuada (PDC) 12 do PERH 1994/1995

\begin{tabular}{|l|l|}
\hline \multicolumn{2}{|c|}{ PDC 12: PARTICIPAÇÃO DO SETOR PRIVADO - PPSP } \\
\hline \hline Sub-Programas & Ação \\
\hline \hline & $\begin{array}{c}\text { Promoção da participação do setor privado } \\
\text { em planejamento, projetos, serviços e obras } \\
\text { de recursos hídricos. }\end{array}$ \\
\hline
\end{tabular}




\section{ANEXO 2. Projetos Enviados ao CBH-SMT}

Quadro 20. Relação dos Projetos Enviados ao CBH-SMT no período de 1995 a 2016

\begin{tabular}{|c|c|c|c|c|c|c|c|c|c|c|c|c|c|}
\hline Nome do interessado & $\begin{array}{l}\text { Atividade principal do } \\
\text { interessado }\end{array}$ & $\begin{array}{c}\text { Situação do } \\
\text { emprendimento }\end{array}$ & $\begin{array}{l}\text { Data de } \\
\text { conclusão }\end{array}$ & Valor aprovado & $\begin{array}{c}\text { Valor de } \\
\text { contrapartida }\end{array}$ & Valor total & $\begin{array}{l}\text { Segmento do } \\
\text { interessado }\end{array}$ & Modalidade & $\begin{array}{l}\text { Benefício: } \\
\text { indicador }\end{array}$ & $\begin{array}{l}\text { População } \\
\text { beneficiada }\end{array}$ & PDC: sigla & $\begin{array}{l}\text { Tempo de } \\
\text { execução } \\
\text { (meses) }\end{array}$ & Descrição \\
\hline $\begin{array}{c}\text { ASSOCIAÇÃO } \\
\text { ECOAR FLORESTAL }\end{array}$ & $\begin{array}{l}\text { REALIZAÇ̃̃O DE } \\
\text { PROJETOS } \\
\text { SOCIOAMBIENTAIS }\end{array}$ & Concluído & $02 / 05 / 2013$ & $131.913,98$ & $62.974,00$ & $194.887,98$ & Sociedade Civil & Não reemb. & $\begin{array}{l}\text { Recomposição de } \\
\text { Mata Ciliar } \\
\text { (hectares) }\end{array}$ & 100 & PDC01 & 24 & $\begin{array}{l}\text { A PROPOSTA DESSE PROJETOÉ } \\
\text { MELHORAR A QUALDADEDAS } \\
\text { FUTURAS RESTAURAÇÕES } \\
\text { FLORESTAIS NATIVAS EM ÁREAS }\end{array}$ \\
\hline $\begin{array}{c}\text { SERVIÇO } \\
\text { AUTÔNOMO DE } \\
\text { ÁGUA EESGOTO DE } \\
\text { PORTO FELIZ (SAAE) }\end{array}$ & $\begin{array}{l}\text { PREFEITURA } \\
\text { MUNICIPAL }\end{array}$ & Cancelado & 14/08/2009 & $142.344,92$ & $37.838,52$ & $180.183,44$ & Município & Não reemb. & $\begin{array}{l}\text { Estudos/Projetos } \\
\text { (contratos) }\end{array}$ & 42000 & PDC01 & 12 & $\begin{array}{l}\text { DESENVOLVER UM SISTEMA DE } \\
\text { MONITORAMENTO DA QUALDADE } \\
\text { DA ÁGUA DAS APAS AVECUIA E } \\
\text { ENGENHO D'ÁGUA. }\end{array}$ \\
\hline $\begin{array}{l}\text { COMPANHIA DE } \\
\text { SANEAMENTO } \\
\text { BÁSICO DO ESTADO } \\
\text { DE SÃO PAULO- } \\
\text { SABESP }\end{array}$ & $\begin{array}{l}\text { SANEAMENTO } \\
\text { BÁSICO }\end{array}$ & Concluído & 26/05/2010 & $179.986,54$ & $70.686,99$ & $250.673,53$ & Estado & Reembolsável & $\begin{array}{l}\text { Coleta e } \\
\text { Tratamento de } \\
\text { Esgotos } \\
\text { (habitantes) }\end{array}$ & 20000 & $\mathrm{PDC}_{3}$ & 9 & $\begin{array}{c}\text { PROPICIAR A FUTURA IMPLANTAÇÃO } \\
\text { DE SISTEMA DE AFASTAMENTOE } \\
\text { TRATAMENTO, COM A CONSEQÜENTE } \\
\text { MELHORIA SA }\end{array}$ \\
\hline $\begin{array}{c}\text { UNESP - } \\
\text { UNIVERSIDADE } \\
\text { ESTADUAL } \\
\text { PAULISTA JÚLIO DE } \\
\text { MESQUITA FILHO }\end{array}$ & $\begin{array}{l}\text { INSTITUICCÃO DE } \\
\text { ENSINO SUPERIOR }\end{array}$ & Cancelado & 04/01/2007 & 0 & 0 & 0 & Estado & Não reemb. & $\begin{array}{l}\text { Estudos/Projetos } \\
\text { (contratos) }\end{array}$ & 300000 & PDC01 & 12 & $\begin{array}{l}\text { O OBJETIVO FUNDAMENTAL DESTE } \\
\text { ESTUDO É REALIZAR A } \\
\text { INVESTIGAÇÃO DE IMPACTOS } \\
\text { ANTROPOGÊNICOS NA CONCENTR }\end{array}$ \\
\hline $\begin{array}{l}\text { INSTITUTO VISÂO } \\
\text { FUTURO }\end{array}$ & $\begin{array}{l}\text { DESENVOLVIMENTO } \\
\text { DECURSOS, } \\
\text { EVENTOS, E } \\
\text { ATIVIDADES SÓCIO- } \\
\text { EDUCACIONAIS, } \\
\text { AMBIENTAIS EDE } \\
\text { GERAÇÃO DE REND }\end{array}$ & Concluído & 20/03/2014 & $67.251,00$ & $50.169,40$ & $117.420,40$ & Sociedade Civil & Não reemb. & $\begin{array}{l}\text { Educação } \\
\text { Ambiental } \\
\text { (contratos) }\end{array}$ & 100000 & PDC01 & 12 & $\begin{array}{c}\text { DESENVOLVER PROGRAMA INOVADOR } \\
\text { DE EDUCAÇÃO AMBIENTAL, DE } \\
\text { CARÁTER MULTIPLCADOR E EFETIVO, } \\
\text { ENVOLVENDO }\end{array}$ \\
\hline $\begin{array}{l}\text { INSTITUTO AUÁ DE } \\
\text { EMPREENDEDORISM } \\
\text { O SOCIOAMBIENTAL }\end{array}$ & $\begin{array}{l}\text { DESENVOLVIMENTO } \\
\text { SUSTENTÁVEL, } \\
\text { ATRAVÉS DO }\end{array}$ & Concluído & 14/04/2011 & $138.136,10$ & $61.153,40$ & $199.289,50$ & Sociedade Civil & Não reemb. & $\begin{array}{l}\text { Estudos/Projetos } \\
\text { (contratos) }\end{array}$ & 200000 & PDC05 & 12 & $\begin{array}{l}\text { O PROJETO DE ELABORAÇÃO DO } \\
\text { PLANO DE MANEJO DO MANANCIAL } \\
\text { DA BOA VISTA OBJETIVA A }\end{array}$ \\
\hline $\begin{array}{c}\text { PREFEITURA } \\
\text { MUNICIPAL DE } \\
\text { CESÁRIO LANGE }\end{array}$ & $\begin{array}{c}\text { PÚBLICA/EXECUTIV } \\
\text { A }\end{array}$ & Cancelado & 29/12/2006 & 0 & 0 & 0 & Munićípio & Não reemb. & $\begin{array}{l}\text { Trat.e Disposição } \\
\text { de Lixo - Obras } \\
\text { (habitantes) }\end{array}$ & 25000 & PDC01 & 12 & $\begin{array}{l}\text { DE MODO A ATENDER A LEGISLACCÃO } \\
\text { AMBIENTAL UMA VEZ QUE O ANTIGO } \\
\text { LIXÃO NAO TEM MAIS CONDIÇÕES DE } \\
\text { RECEBE }\end{array}$ \\
\hline $\begin{array}{c}\text { CONSÓRCIO DE } \\
\text { ESTUDOS, } \\
\text { RECUPERAÇÃO E } \\
\text { DESENVOLVIMENTO } \\
\text { DA BACIA DOS RIOS } \\
\text { SOROCABA E MÉDIO } \\
\text { TIETÊ- CERISO }\end{array}$ & $\begin{array}{l}\text { CONSÓRCIO } \\
\text { INTERMUNICIPAL }\end{array}$ & Concluído & 20/01/2009 & $152.509,17$ & 0 & $152.509,17$ & Sociedade Civil & Não reemb. & $\begin{array}{l}\text { Estudos/Projetos } \\
\text { (contratos) }\end{array}$ & 1560000 & PDC01 & 12 & $\begin{array}{c}\text { TENDO EM VISTA AS CONTRIBUIÇ̃̃ES } \\
\text { DO COMITÊ DE BACIAS EAS } \\
\text { DIFICULDADES ORA ENCONTRADAS } \\
\text { PELA SECRETARI }\end{array}$ \\
\hline $\begin{array}{c}\text { CONSÓRCIO DE } \\
\text { ESTUDOS, } \\
\text { RECUPERAÇÃO E } \\
\text { DESENVOLVMENTO } \\
\text { DA BACIA DOS RIOS } \\
\text { SOROCABA E MÉDIO } \\
\text { TIETÊ - CERISO }\end{array}$ & $\begin{array}{l}\text { CONSÓRCIO } \\
\text { INTERMUNICIPAL }\end{array}$ & Cancelado & 04/01/2007 & 0 & 0 & 0 & Sociedade Civil & Não reemb. & $\begin{array}{l}\text { Estudos/Projetos } \\
\text { (contratos) }\end{array}$ & 1560000 & $\mathrm{PDC} 03$ & 12 & $\begin{array}{l}\text { DIAGNNÓSTICO E PERSPECTIVAS DA } \\
\text { SITUAÇÃO DE RESÍDUOS DE SERVIÇOS } \\
\text { DESAÚDE (RSS) - TIPO E QUANTIDADE } \\
\text { DE }\end{array}$ \\
\hline
\end{tabular}




\begin{tabular}{|c|c|c|c|c|c|c|c|c|c|c|c|c|c|}
\hline Nome do interessado & $\begin{array}{l}\text { Atividade principal do } \\
\text { interessado }\end{array}$ & $\begin{array}{c}\text { Situação do } \\
\text { empreendimento }\end{array}$ & $\begin{array}{c}\text { Data de } \\
\text { conclusão }\end{array}$ & Valor aprovado & $\begin{array}{c}\text { Valor de } \\
\text { contrapartida }\end{array}$ & Valor total & $\begin{array}{l}\text { Segmento do } \\
\text { interessado }\end{array}$ & Modalidade & $\begin{array}{l}\text { Benefício: } \\
\text { indicador }\end{array}$ & $\begin{array}{c}\text { População } \\
\text { beneficiada }\end{array}$ & PDC: sigla & $\begin{array}{l}\text { Tempo de } \\
\text { execução } \\
\text { (meses) }\end{array}$ & Descrição \\
\hline $\begin{array}{l}\text { PREFEITURA } \\
\text { MUNIIIPAL DE } \\
\text { BOTUCATU }\end{array}$ & $\begin{array}{l}\text { PREFEITURA } \\
\text { MUNICIPAL }\end{array}$ & Concluído & $15 / 05 / 2013$ & $84.779,20$ & $44.804,00$ & $129.583,20$ & Município & Não reemb. & $\begin{array}{c}\text { Estudos/Projetos } \\
\text { (contratos) }\end{array}$ & 120000 & PDC01 & 24 & $\begin{array}{l}\text { PROBLEMA A SER ENFRENTADO OU } \\
\text { MINIMIZADO - P.EX: REDUZIR A } \\
\text { POLUIÇÃ̃ NO RIBEIRÃO DA ONÇA; } \\
\text { DESENVOLVER }\end{array}$ \\
\hline $\begin{array}{c}\text { PREFEITURA } \\
\text { MUNICIPALDE } \\
\text { VARGEM GRANDE } \\
\text { PAULISTA }\end{array}$ & $\begin{array}{l}\text { PREFEITURA } \\
\text { MUNICIPAL }\end{array}$ & Cancelado & 14/08/2009 & $117.078,00$ & $31.272,00$ & $148.350,00$ & Município & Não reemb. & $\begin{array}{l}\text { Trat. e Disposiç̃ão } \\
\text { de Lixo - Obras } \\
\text { (habitantes) }\end{array}$ & 43217 & $\mathrm{PDC}_{3}$ & 12 & $\begin{array}{l}\text { PROMOVER A RECUPERAÇ̃̃O } \\
\text { AMBIENTALDA ÁREA DEGRADADA } \\
\text { POR DISPOSIÇÃO DE RESÍ́DUOS } \\
\text { SÓLIDOS URBANOS, O VAZ }\end{array}$ \\
\hline $\begin{array}{l}\text { PREFEITURA } \\
\text { MUNICIPALDE } \\
\text { IPERÓ }\end{array}$ & $\begin{array}{l}\text { PREFEITURA } \\
\text { MUNICIPAL }\end{array}$ & Concluído & 07/08/2009 & $179.145,44$ & $104.939,76$ & $284.085,20$ & Município & Não reemb. & $\begin{array}{l}\text { Coleta e } \\
\text { Tratamento de } \\
\text { Esgotos } \\
\text { (habitantes) }\end{array}$ & 60000 & $\mathrm{PDC} 03$ & 6 & $\begin{array}{l}\text { OS EFLUENTES DOMÉSTICOS SÃO } \\
\text { LANÇADOS IN NATURA EM CORPOS } \\
\text { D’Á GUA ENO SOLO. }\end{array}$ \\
\hline $\begin{array}{l}\text { PREFEITURA } \\
\text { MUNICIPALDE } \\
\text { LARANJAL } \\
\text { PAULISTA } \\
\text { AGÊNCIA }\end{array}$ & $\begin{array}{l}\text { PREFEITURA } \\
\text { MUNICIPAL }\end{array}$ & Cancelado & 05/10/2006 & 0 & 0 & 0 & Munićípio & Não reemb. & Outros (contratos) & 30000 & PDC01 & 12 & $\begin{array}{l}\text { O PROJETO TEM COMO PROPÓSITO } \\
\text { MAIS ABRANGENTE, A CRIAÇ̃̃O DE } \\
\text { UM VIVEIRO DE MUDAS PARA } \\
\text { FORNECIMENTO DE }\end{array}$ \\
\hline $\begin{array}{l}\text { REGULADORA DE } \\
\text { SERVICCOS } \\
\text { DELEGADOS DO } \\
\text { MUNICÍPIO DA } \\
\text { ESTÂNCIA } \\
\text { TURÍSTICA DE ITU - } \\
\text { AR-ITU }\end{array}$ & $\begin{array}{l}\text { SANEAMENTO } \\
\text { BÁSICO }\end{array}$ & Concluído & 19/06/2012 & $90.000,00$ & $29.571,50$ & $119.571,50$ & Munićípio & Não reemb. & $\begin{array}{l}\text { Estudos/Projetos } \\
\text { (contratos) }\end{array}$ & 135000 & PDC01 & 12 & $\begin{array}{l}\text { OBJETIVO: EFETUAR ESTUDO, À LUZ } \\
\text { DAS INTERFERÊNCIAS ANTRÓPICAS, } \\
\text { DE CARACTERIZAÇÃO E } \\
\text { MONITORAMENTO, DO }\end{array}$ \\
\hline $\begin{array}{c}\text { ORGANIZAÇ̃̃O } \\
\text { AMBIENTALISTA } \\
\text { AMAINAN BRASIL }\end{array}$ & $\begin{array}{l}\text { CONSERVAČ̃̃̃O EM } \\
\text { MATA ATLÂNTICA }\end{array}$ & Concluído & 13/02/2014 & $36.590,72$ & $24.817,78$ & $61.408,50$ & Sociedade Civil & Não reemb. & $\begin{array}{l}\text { Educação } \\
\text { Ambiental } \\
\text { (contratos) }\end{array}$ & 600000 & PDC01 & 12 & $\begin{array}{l}\text { LEVANTAR DE FORMA APROPRIADA } \\
\text { O USO NA CONSTRUCCÃO CIVIL DOS } \\
\text { RECURSOS NATURAIS QUE } \\
\text { OCASIONAM IMPACTOS }\end{array}$ \\
\hline $\begin{array}{l}\text { CONSÓRCIO DE } \\
\text { ESTUDOS, } \\
\text { RECUPERAÇÃ̃O E } \\
\text { DESENVOLVIMENTO } \\
\text { DA BACIA DOS RIOS } \\
\text { SOROCABA EMÉDIO } \\
\text { TIETÊ- CERISO }\end{array}$ & $\begin{array}{c}\text { CONSÓRCIO } \\
\text { INTERMUNICIPAL }\end{array}$ & Concluído & 01/07/2011 & $265.000,00$ & 0 & $265.000,00$ & Sociedade Civil & Não reemb. & $\begin{array}{l}\text { Planej.e Gerenc. } \\
\text { dos Recs. Hídricos } \\
\text { (contratos) }\end{array}$ & 1600000 & PDC01 & 5 & $\begin{array}{l}\text { OS TRABALHOS PROPOSTOS TêM } \\
\text { COMO OBJETIVO ELABORAR A } \\
\text { COMPLEMENTAçãO DO PLANO DE } \\
\text { BACIA DO SOROCABA EM }\end{array}$ \\
\hline ASSOCIAÇÃO JAPI & MEIO AMBIENTE & Cancelado & $11 / 04 / 2008$ & 0 & 0 & 0 & Sociedade Civil & Não reemb. & $\begin{array}{l}\text { Educação } \\
\text { Ambiental } \\
\text { (contratos) }\end{array}$ & 45000 & PDC01 & 5 & $\begin{array}{l}\text { PROTEČ̃̃O DOS RECURSOS NATURAIS } \\
\text { DO MUNICÍPIO DE CABREÚVA (SERRA } \\
\text { DO JAPI COM SEUS MANANCIAIS DE }\end{array}$ \\
\hline $\begin{array}{l}\text { UNESP - } \\
\text { UNIVERSIDADE } \\
\text { ESTADUAL } \\
\text { PAULISTA JÚLIO DE } \\
\text { MESQUITA FILHO }\end{array}$ & $\begin{array}{c}\text { INSTITUIÇÃO DE } \\
\text { ENSINO SUPERIOR }\end{array}$ & Cancelado & 10/04/2008 & 0 & 0 & 0 & Estado & Não reemb. & $\begin{array}{l}\text { Estudos/Projetos } \\
\text { (contratos) }\end{array}$ & 700000 & $\mathrm{PDC} 01$ & 12 & $\begin{array}{l}\text { O OBJETIVO FUNDAMENTAL DESTE } \\
\text { ESTUDO É REALIZAR A INVESTIGAçãO } \\
\text { DE POSSiVEIS IMPACTOS } \\
\text { ANTROPOGêNICOS N }\end{array}$ \\
\hline
\end{tabular}




\begin{tabular}{|c|c|c|c|c|c|c|c|c|c|c|c|c|c|}
\hline Nome do interessado & $\begin{array}{l}\text { Atividade principal do } \\
\text { interessado }\end{array}$ & $\begin{array}{l}\text { Situação do } \\
\text { empreendimento }\end{array}$ & $\begin{array}{l}\text { Data de } \\
\text { conclusão }\end{array}$ & Valor aprovado & $\begin{array}{c}\text { Valor de } \\
\text { contrapartida }\end{array}$ & Valor total & $\begin{array}{l}\text { Segmento do } \\
\text { interessado }\end{array}$ & Modalidade & $\begin{array}{l}\text { Benefíicio: } \\
\text { indicador }\end{array}$ & $\begin{array}{l}\text { Populacã̃o } \\
\text { beneficiada }\end{array}$ & PDC: sigla & $\begin{array}{l}\text { Tempo de } \\
\text { execução } \\
\text { (meses) }\end{array}$ & Descrição \\
\hline $\begin{array}{l}\text { CEADEC - CENTRO } \\
\text { DEESTUDOS E } \\
\text { APOIO AO } \\
\text { DESENVOLVIMENTO, }\end{array}$ & $\begin{array}{l}\text { PROMOVER E } \\
\text { APOIAR } \\
\text { INICIATIVAS } \\
\text { RELATIVAS à }\end{array}$ & Cancelado & 10/04/2008 & 0 & 0 & 0 & Sociedade Civil & Não reemb. & $\begin{array}{c}\text { Estudos/Projetos } \\
\text { (contratos) }\end{array}$ & 234968 & $\mathrm{PDC}_{3}$ & 12 & $\begin{array}{l}\text { - INICIAR E APERFEIÇOAR A COLETA } \\
\text { SELETIVA DE QUATRO MUNICIPIOS - } \\
\text { IBIÚNA, MAIRINQUE, SãO ROQUEE } \\
\text { VARG }\end{array}$ \\
\hline $\begin{array}{l}\text { PREFEITURA } \\
\text { MUNICIPAL DA } \\
\text { ESTÂNCIA } \\
\text { TURIISTICA DE } \\
\text { IBIUUNA }\end{array}$ & $\begin{array}{l}\text { PREFEITURA } \\
\text { MUNICIPAL }\end{array}$ & Cancelado & $11 / 04 / 2008$ & 0 & 0 & 0 & Município & Não reemb. & $\begin{array}{l}\text { Educação } \\
\text { Ambiental } \\
\text { (contratos) }\end{array}$ & 1200 & PDC01 & 12 & $\begin{array}{c}\text { O RIBEIRãO DO MURUNDU é UM DOS } \\
\text { CURSOS D'áGUA QUE Dá ORIGEM AO } \\
\text { RIO SOROCABUÇU, QUE POR SUA VEZ } \\
\text { DA ORI }\end{array}$ \\
\hline $\begin{array}{c}\text { ASSOCIACCÃO } \\
\text { JORNADA } \\
\text { ECOLÓGICA - AJE }\end{array}$ & $\begin{array}{c}\text { PROTECCÃO AO } \\
\text { MEIO AMBIENTE }\end{array}$ & Concluído & $14 / 02 / 2012$ & $107.088,67$ & $28.703,32$ & $135.791,99$ & Sociedade Civil & Não reemb. & $\begin{array}{l}\text { Estudos/Projetos } \\
\text { (contratos) }\end{array}$ & 160000000 & PDC01 & 12 & $\begin{array}{l}\text { ESTUDO E ANáLISE DAS LEGISLAç̄ōES } \\
\text { AMBIENTAIS MUNICIPAIS EM FACE } \\
\text { DA ESTADUALE FEDERAL. } \\
\text { PROPOSTAS DE A }\end{array}$ \\
\hline $\begin{array}{l}\text { SERVICCO } \\
\text { AUTÔNOMO DE } \\
\text { ÁGUA EESGOTO DE } \\
\text { CERQUILHO }\end{array}$ & $\begin{array}{l}\text { SERVIÇO DE } \\
\text { SANEAMENTO } \\
\text { BÁSICO }\end{array}$ & Concluído & 30/12/2009 & $176.264,40$ & $468.735,59$ & $644.999,99$ & Município & Não reemb. & $\begin{array}{l}\text { Coleta e } \\
\text { Tratamento de } \\
\text { Esgotos } \\
\text { (habitantes) }\end{array}$ & 30000 & $\mathrm{PDC}_{3}$ & 7 & $\begin{array}{l}\text { TRATAMENTO DE 100\% DOS ESGOTOS } \\
\text { DA BACIA DO RIBEIRÃO DA SERRA, } \\
\text { AFLUENTE DO RIO TIETÊ. }\end{array}$ \\
\hline $\begin{array}{l}\text { SOS CUESTA DE } \\
\text { BOTUCATU }\end{array}$ & $\begin{array}{c}\text { PRESERVAÇÃO DO } \\
\text { MEIO AMBIENTE }\end{array}$ & Cancelado & 20/12/2007 & 0 & 0 & 0 & Sociedade Civil & Reembolsável & $\begin{array}{l}\text { Estudos/Projetos } \\
\text { (contratos) }\end{array}$ & 2500 & PDC01 & 17 & $\begin{array}{c}\text { PLANEIAR AçōES ESTRATéGICAS DE } \\
\text { CONSERVAçãO DA NATUREZA NA } \\
\text { BACIA DO RIO CAPIVARA QUE } \\
\text { ASSOCIEM A PROTE }\end{array}$ \\
\hline $\begin{array}{l}5 \text { ELEMENTOS - } \\
\text { INSTITUTO DE } \\
\text { EDUCAÇÃO E } \\
\text { PESQUISA } \\
\text { AMBIENTAL }\end{array}$ & $\begin{array}{l}\text { EDUCAÇ̃̃O } \\
\text { AMBIENTAL }\end{array}$ & Concluído & 20/07/2010 & $142.068,68$ & $37.904,30$ & $179.972,98$ & Sociedade Civil & Não reemb. & $\begin{array}{l}\text { Estudos/Projetos } \\
\text { (contratos) }\end{array}$ & 1654736 & PDC01 & 12 & $\begin{array}{l}\text { O PRESENTE PROJETO TEM COMO } \\
\text { PRINCIPAL OBJETIVO O DIAGNóSTICO } \\
\text { E A PUBLICAçãO DE DADOS EM } \\
\text { FORMA DE ATL }\end{array}$ \\
\hline $\begin{array}{l}\text { PREFEITURA } \\
\text { MUNICIPALDE } \\
\text { PORTO FELLZ }\end{array}$ & $\begin{array}{l}\text { PREFEITURA } \\
\text { MUNICIPAL }\end{array}$ & Concluído & 22/07/2009 & $172.532,41$ & $108.039,66$ & $280.572,07$ & Município & Não reemb. & $\begin{array}{l}\text { Coleta e } \\
\text { Tratamento de } \\
\text { Esgotos } \\
\text { (habitantes) }\end{array}$ & 5500 & $\mathrm{PDC}_{3}$ & 8 & $\begin{array}{c}\text { (PROBLEMA A SER ENFRENTADO OU } \\
\text { MINIMIZADO - P.EX.: REDUZIR A } \\
\text { POLUIção NO RIBEIRãO DA ONçA; } \\
\text { DESENVOLVE }\end{array}$ \\
\hline $\begin{array}{l}\text { CONSÓRCIO DE } \\
\text { ESTUDOS, } \\
\text { RECUPERAÇÃ̂O E } \\
\text { DESENVOLVIMENTO } \\
\text { DA BACIA DOS RIOS } \\
\text { SOROCABA E MÉDIO } \\
\text { TIETÊ - CERISO }\end{array}$ & $\begin{array}{c}\text { CONSÓRCIO } \\
\text { INTERMUNICIPAL }\end{array}$ & Concluído & 24/04/2010 & $209.349,00$ & 0 & 209.349,00 & Sociedade Civil & Não reemb. & $\begin{array}{l}\text { Planej. e Gerenc. } \\
\text { dos Recs. Hídricos } \\
\text { (contratos) }\end{array}$ & 1600000 & PDC01 & 12 & $\begin{array}{l}\text { TENDO EM VISTA AS ATRIBUIç̃̃ES DO } \\
\text { COMITê DE BACIAS, AS } \\
\text { DIFICULDADES ORA ENCONTRADAS } \\
\text { PELA SECRETARIA E }\end{array}$ \\
\hline $\begin{array}{l}\text { CONSÓRCIO DE } \\
\text { ESTUDOS, } \\
\text { RECUPERAČÃO E } \\
\text { DESENVOLVIMENTO } \\
\text { PREFEITURA } \\
\text { MUNICIPALDE } \\
\text { MAIRINQUE }\end{array}$ & $\begin{array}{c}\text { CONSÓRCIO } \\
\text { INTERMUNICIPAL }\end{array}$ & Cancelado & $11 / 04 / 2008$ & $144.000,00$ & $36.000,00$ & $180.000,00$ & Sociedade Civil & Não reemb. & $\begin{array}{l}\text { Estudos/Projetos } \\
\text { (contratos) }\end{array}$ & 212300 & PDC05 & 10 & $\begin{array}{c}\text { O OBJETIVO DESTE PROJETO DE AÇÕES } \\
\text { DE COMBATE A PERDAS DE ÁGUA É } \\
\text { DAR CONTINUIDADE AS ATIVIDADES } \\
\text { DO PL } \\
\text { OBJETIVO: (PROBLEMA A SER } \\
\text { ENFRENTADO OU MINIMIZADO - P.EX: } \\
\text { REDUZIR A POLUIçãO NO RIBEIRãO DA } \\
\text { ONÇA; }\end{array}$ \\
\hline
\end{tabular}




\begin{tabular}{|c|c|c|c|c|c|c|c|c|c|c|c|c|c|}
\hline Nome do interessado & $\begin{array}{l}\text { Atividade principal do } \\
\text { interessado }\end{array}$ & $\begin{array}{c}\text { Situação do } \\
\text { empreendimento }\end{array}$ & $\begin{array}{c}\text { Data de } \\
\text { conclusão }\end{array}$ & Valor aprovado & $\begin{array}{c}\text { Valor de } \\
\text { contrapartida }\end{array}$ & Valor total & $\begin{array}{l}\text { Segmento do } \\
\text { interessado }\end{array}$ & Modalidade & $\begin{array}{l}\text { Benefício: } \\
\text { indicador }\end{array}$ & $\begin{array}{l}\text { População } \\
\text { beneficiada }\end{array}$ & PDC: sigla & $\begin{array}{l}\text { Tempo de } \\
\text { execução } \\
\text { (meses) }\end{array}$ & Descrição \\
\hline $\begin{array}{l}5 \text { ELEMENTOS - } \\
\text { INSTITUTO DE } \\
\text { EDUCAÇ̃̃O E } \\
\text { PESQUISA } \\
\text { AMBIENTAL }\end{array}$ & $\begin{array}{l}\text { EDUCAÇ̃̃O } \\
\text { AMBIENTAL }\end{array}$ & Concluído & 08/08/2012 & $118.712,42$ & $29.633,52$ & $148.345,94$ & Sociedade Civil & Não reemb. & $\begin{array}{l}\text { Educação } \\
\text { Ambiental } \\
\text { (contratos) }\end{array}$ & 1374000 & PDC01 & 10 & $\begin{array}{l}\text { A PROPOSTA ENQUADRA-SENA } \\
\text { LINHA TEMáTICA PLANEJAMENTO E } \\
\text { GERENCIAMENTO DE RECURSOS } \\
\text { HiDRICOS - AçãO: C }\end{array}$ \\
\hline $\begin{array}{c}\text { CONSÓRCIO DE } \\
\text { ESTUDOS, } \\
\text { RECUPERAÇÃO E } \\
\text { DESENVOLVIMENTO }\end{array}$ & $\begin{array}{c}\text { CONSÓRCIO } \\
\text { INTERMUNICIPAL }\end{array}$ & Concluído & 09/08/2012 & $143.200,00$ & $35.603,00$ & $178.803,00$ & Sociedade Civil & Não reemb. & $\begin{array}{l}\text { Planej. e Gerenc. } \\
\text { dos Recs. Hidricos } \\
\text { (contratos) }\end{array}$ & 250000 & PDC05 & 6 & $\begin{array}{l}\text { REDUção DE PERDAS DE ́áGUA NOS } \\
\text { SISTEMAS DE ABASTECIMENTO } \\
\text { PúBLICO NOS MUNICIPIOS CITADOS. }\end{array}$ \\
\hline $\begin{array}{c}\text { CONSÓRCIO DE } \\
\text { ESTUDOS, } \\
\text { RECUPERAÇÃO E } \\
\text { DESENVOLVIMENTO } \\
\text { DA BACIA DOS RIOS } \\
\text { SOROCABA E MÉDIO } \\
\text { TIETÊ- CERISO }\end{array}$ & $\begin{array}{c}\text { CONSÓRCIO } \\
\text { INTERMUNICIPAL }\end{array}$ & Concluído & $14 / 05 / 2013$ & $337.958,00$ & 0 & $337.958,00$ & Sociedade Civil & Não reemb. & Outros (contratos) & 1600000 & PDC01 & 12 & $\begin{array}{l}\text { ESTE PROJETO PROPõE A } \\
\text { CONTRATAção DE SERVIçOS PARA } \\
\text { DAR CONTINUIDADE DO PLANO DE } \\
\text { COMUNICA̧̧ãO EA COMP }\end{array}$ \\
\hline $\begin{array}{c}\text { AGÊNCIA } \\
\text { REGULADORA DE } \\
\text { SERVIÇOS } \\
\text { DELEGADOS DO } \\
\text { MUNICÍPIO DA } \\
\text { ESTÂNCIA } \\
\text { TURÍSTICA DE ITU - } \\
\text { AR-ITU }\end{array}$ & $\begin{array}{l}\text { SANEAMENTO } \\
\text { BÁSICO }\end{array}$ & Cancelado & 11/05/2011 & $179.937,95$ & $303.506,31$ & $483.444,26$ & Município & Não reemb. & $\begin{array}{l}\text { Recomposição de } \\
\text { Mata Ciliar } \\
\text { (hectares) }\end{array}$ & 100000 & PDC09 & 24 & $\begin{array}{c}\text { REVEGETAÇão DE áREAS DE PROTEçãO } \\
\text { PERMANENTE NA BACIA DO CóRREGO } \\
\text { SãO JOSé é PROJETO E OBRA DE } \\
\text { CONERS }\end{array}$ \\
\hline $\begin{array}{l}\text { PREFEITURA } \\
\text { MUNICIPALDE } \\
\text { VOTORANTIM }\end{array}$ & $\begin{array}{l}\text { PREFEITURA } \\
\text { MUNICIPAL }\end{array}$ & Concluído & $14 / 05 / 2013$ & $149.696,98$ & $66.541,78$ & $216.238,76$ & Município & Não reemb. & $\begin{array}{l}\text { Recomposiç̃ão de } \\
\text { Mata Ciliar } \\
\text { (hectares) }\end{array}$ & 800000 & PDC09 & 24 & $\begin{array}{l}\text { RESTAURACCÃO DE ÁREAS DE MATA } \\
\text { CILIAR DO RIO SOROCABA, MUNICIPIO } \\
\text { DE VOTORANTIM, ATRA VÉS DE } \\
\text { PARTICIPAÇÃ }\end{array}$ \\
\hline $\begin{array}{l}\text { PREFEITURA } \\
\text { MUNICIPALDE } \\
\text { JUMIRIM }\end{array}$ & $\begin{array}{l}\text { PREFEITURA } \\
\text { MUNICIPAL }\end{array}$ & Concluído & 27/08/2009 & $71.715,23$ & $35.101,17$ & $106.816,40$ & Município & Não reemb. & $\begin{array}{l}\text { Coleta e } \\
\text { Tratamento de } \\
\text { Esgotos } \\
\text { (habitantes) }\end{array}$ & 10000 & $\mathrm{PDCO}_{3}$ & 2 & $\begin{array}{l}\text { TRATAMENTO DOS EFLUENTES DOS } \\
\text { SISTEMAS URBANOS DE ÁGUA E } \\
\text { ESGOTO }\end{array}$ \\
\hline $\begin{array}{l}\text { PREFEITURA } \\
\text { MUNICIPALDE } \\
\text { PEREIRAS }\end{array}$ & $\begin{array}{l}\text { PREFEITURA } \\
\text { MUNICIPAL }\end{array}$ & Concluído & 16/10/2012 & $72.000,00$ & $18.000,00$ & $90.000,00$ & Município & Não reemb. & $\begin{array}{l}\text { Abastecimento de } \\
\text { Água (habitantes) }\end{array}$ & 8000 & $\mathrm{PDC} 02$ & 3 & $\begin{array}{l}\text { CONTRATAR UM PROJETO BÁSICO } \\
\text { QUE IDENTIFIQUE ALTERNATIVAS DE } \\
\text { ABASTECIMENTO PÚBLICO PARA O } \\
\text { MUNICIPIO, }\end{array}$ \\
\hline $\begin{array}{l}\text { PREFEITURA } \\
\text { MUNICIPALDE } \\
\text { TATUÍ }\end{array}$ & $\begin{array}{l}\text { PREFEITURA } \\
\text { MUNICIPAL }\end{array}$ & Concluído & $15 / 08 / 2013$ & $34.645,00$ & $13.800,00$ & $48.445,00$ & Município & Não reemb. & $\begin{array}{l}\text { Recomposiç̃ão de } \\
\text { Mata Ciliar } \\
\text { (hectares) }\end{array}$ & 40000 & PDC09 & 18 & $\begin{array}{l}\text { A RECUPERAČ̃̃ DA ÁREA EM } \\
\text { ESTUDO É URGENTE, POIS SEU } \\
\text { ABANDONO, LEVAM AO USO } \\
\text { PREDATÓRIO COM DEPÓSITO D }\end{array}$ \\
\hline $\begin{array}{l}\text { COOPERATIVA DE } \\
\text { RECICLAGEM } \\
\text { RENASCER }\end{array}$ & $\begin{array}{l}\text { COLETA DE } \\
\text { MATERIAIS } \\
\text { RECICLADOS }\end{array}$ & Cancelado & $12 / 11 / 2008$ & 0 & 0 & 0 & Sociedade Civil & Não reemb. & $\begin{array}{l}\text { Trat. e Disposição } \\
\text { de Lixo - Obras } \\
\text { (habitantes) }\end{array}$ & 93430 & $\mathrm{PDC}_{3}$ & 10 & $\begin{array}{c}\text { AUMENTAR O NúMERO DE FAMILIAS } \\
\text { ATENDIDAS, ATINGINDO UMA META } \\
\text { DE 50 NO PERIODO DE DOZE MESES E } \\
\text { DIMINUI }\end{array}$ \\
\hline $\begin{array}{l}\text { CONSÓRCIO DE } \\
\text { ESTUDOS, } \\
\text { RECUPERAÇ̃̃̃O E } \\
\text { DESENVOLVIMENTO } \\
\text { DA BACIA DOS RIOS } \\
\text { SOROCABA E MÉDIO } \\
\text { TIETÊ- CERISO }\end{array}$ & $\begin{array}{c}\text { CONSÓRCIO } \\
\text { INTERMUNICIPAL }\end{array}$ & Cancelado & 05/07/2010 & $81.600,00$ & 0 & $81.600,00$ & Sociedade Civil & Não reemb. & Outros (contratos) & 2000000 & PDC01 & 12 & $\begin{array}{l}\text { TRATA-SE DE UMA ATIVIDADE DE } \\
\text { SUPORTEE APOIO AOS USUÁRIOS DO } \\
\text { SISTEMA SIGRH PARA GERENCIAR OS } \\
\text { RECURSO }\end{array}$ \\
\hline
\end{tabular}




\begin{tabular}{|c|c|c|c|c|c|c|c|c|c|c|c|c|c|}
\hline Nome do interessado & $\begin{array}{l}\text { Atividade principal do } \\
\text { interessado }\end{array}$ & $\begin{array}{l}\text { Situação do } \\
\text { empreendimento }\end{array}$ & $\begin{array}{l}\text { Data de } \\
\text { conclusão }\end{array}$ & Valor aprovado & $\begin{array}{c}\text { Valor de } \\
\text { contrapartida }\end{array}$ & Valor total & $\begin{array}{l}\text { Segmento do } \\
\text { interessado }\end{array}$ & Modalidade & $\begin{array}{l}\text { Benefício: } \\
\text { indicador }\end{array}$ & $\begin{array}{c}\text { Populacãa } \\
\text { beneficiada }\end{array}$ & PDC: sigla & $\begin{array}{l}\text { Tempo de } \\
\text { execução } \\
\text { (meses) }\end{array}$ & Descrição \\
\hline $\begin{array}{l}\text { DEPARTAMENTO DE } \\
\text { AGUAS E ENERGIA } \\
\text { ELETRICA - DAEE } \\
\text { (SÃO PAULO) }\end{array}$ & $\begin{array}{l}\text { AUTARQUIA } \\
\text { PÚBICA } \\
\text { ESTADUAL }\end{array}$ & Concluído & $25 / 11 / 2013$ & $200.000,00$ & $72.684,00$ & $272.684,00$ & Estado & Não reemb. & Outros (contratos) & 1000000 & PDC01 & 12 & $\begin{array}{l}\text { OBTENČ̃̃ DE PARÂMETROS } \\
\text { HIDROLÓGICOS COMO SUPORTE AO } \\
\text { GERENCIAMENTO DOS RECURSOS } \\
\text { HÍDRICOS NA BACIA, EM }\end{array}$ \\
\hline ASSOCIAÇÃO JAPI & MEIO AMBIENTE & Concluído & $27 / 01 / 2014$ & $68.580,23$ & $28.569,60$ & $97.149,83$ & Sociedade Civil & Não reemb. & $\begin{array}{l}\text { Educação } \\
\text { Ambiental } \\
\text { (contratos) }\end{array}$ & 9000 & PDC01 & 7 & $\begin{array}{l}\text { PROMOVER O RECONHECIMENTO DO } \\
\text { RIBEIRãO CABREúVA UTILIZANDO } \\
\text { RECURSOS FOTOGRáFICOS, } \\
\text { LEVANTAMENTO GEOGRá }\end{array}$ \\
\hline $\begin{array}{l}\text { UNIVERSIDADE DE } \\
\text { SOROCABA - } \\
\text { FUNDAÇÃO DOM } \\
\text { AGUIRRE }\end{array}$ & $\begin{array}{l}\text { ENSINO, PESQUISA, } \\
\text { EXTENSÃO }\end{array}$ & Concluído & $18 / 02 / 2014$ & $178.971,80$ & $76.560,00$ & $255.531,80$ & Sociedade Civil & Não reemb. & $\begin{array}{l}\text { Estudos/Projetos } \\
\text { (contratos) }\end{array}$ & 1200000 & PDC09 & 18 & $\begin{array}{l}\text { AVALIAção DOS PROJETOS DE } \\
\text { RECUPERAção DE ÁREAS } \\
\text { DEGRADADAS (RAD) REALIZADOS EM } \\
\text { ÁREAS CIIIARES DA BACI }\end{array}$ \\
\hline $\begin{array}{l}\text { FUNDAÇ̃̃O DE } \\
\text { ESTUDOS E } \\
\text { PESQUISAS } \\
\text { AGRICOLAS E } \\
\text { FLORESTAIS }\end{array}$ & $\begin{array}{c}\text { PESQUISA E } \\
\text { DESENVOLVIMENTO } \\
\text { EXPERIMENTAL EM } \\
\text { CIÊNCIAS FÍSICAS E } \\
\text { NATURAIS }\end{array}$ & Cancelado & 28/12/2011 & $159.406,60$ & $56.331,60$ & $215.738,20$ & Sociedade Civil & Não reemb. & $\begin{array}{l}\text { Planej.e Gerenc. } \\
\text { dos Recs. Hídricos } \\
\text { (contratos) }\end{array}$ & 128397 & PDC01 & 12 & $\begin{array}{l}\text { O PROJETO PROPOSTO TENDO COMO } \\
\text { RESULTADO A GERAção DE } \\
\text { INFORMAçẼS ATUALZADAS E } \\
\text { ATUALZŹVEIS DA áREA }\end{array}$ \\
\hline $\begin{array}{l}\text { PREFEITURA } \\
\text { MUNICIPAL DE } \\
\text { VOTORANTIM }\end{array}$ & $\begin{array}{l}\text { PREFEITURA } \\
\text { MUNICIPAL }\end{array}$ & Cancelado & $14 / 05 / 2010$ & 0 & 0 & 0 & Município & Não reemb. & $\begin{array}{l}\text { Recomposiç̃ão de } \\
\text { Mata Ciliar } \\
\text { (hectares) }\end{array}$ & 1000000 & PDC09 & 24 & $\begin{array}{l}\text { A BACIA HIDROGRÁFICA DO } \\
\text { SOROCABA POSSUI CERCA DE 5.209 } \\
\text { KM르 DE ÁREA ENVOLENDO A } \\
\text { POPULAÇÃO DE UM MIL }\end{array}$ \\
\hline $\begin{array}{l}\text { DEPARTAMENTO DE } \\
\text { AGUAS E ENERGIA } \\
\text { ELETRICA - DAEE } \\
\text { (SÃO PAULO) }\end{array}$ & $\begin{array}{l}\text { AUTARQUIA } \\
\text { PÚBLICA } \\
\text { ESTADUAL }\end{array}$ & Cancelado & $16 / 12 / 2011$ & $180.000,00$ & 0 & $180.000,00$ & Estado & Não reemb. & $\begin{array}{c}\text { Estudos/Projetos } \\
\text { (contratos) }\end{array}$ & 590000 & PDC04 & 12 & $\begin{array}{l}\text { O OBJETIVO DO PRESENTE TERMO DE } \\
\text { REFERÊNCIA ÉA CONTRATAÇÃO DE } \\
\text { SERVIÇOS TÉCNICOS ESPECIALIZADOS } \\
\text { PARA }\end{array}$ \\
\hline $\begin{array}{l}\text { PREFEITURA } \\
\text { MUNICIPAL DE } \\
\text { ARAÇARIGUAMA }\end{array}$ & SERVIÇO PÚBLICO & Concluído & 26/08/2015 & $88.530,96$ & $22.066,70$ & $110.597,66$ & Município & Não reemb. & $\begin{array}{l}\text { Estudos/Projetos } \\
\text { (contratos) }\end{array}$ & 9620 & PDC01 & 11 & $\begin{array}{l}\text { DIAGNÓSTICO DA REALIDADE } \\
\text { AMBIENTAL DA OCUPAÇÃO DO SOLO } \\
\text { NA ÁREA DA SUB-BACIA DO } \\
\text { RIBEIRÃO DO COLÉGIO, }\end{array}$ \\
\hline $\begin{array}{l}\text { IPESA - INSTITUTO } \\
\text { DE PROJETOS E } \\
\text { PESQUIAS } \\
\text { SOCIOAMBIENTAIS }\end{array}$ & MEIO AMBIENTE & Concluído & $28 / 11 / 2013$ & $179.732,11$ & $48.031,58$ & $227.763,69$ & Sociedade Civil & Não reemb. & $\begin{array}{l}\text { Educação } \\
\text { Ambiental } \\
\text { (contratos) }\end{array}$ & 7500 & PDC01 & 12 & $\begin{array}{c}\text { O OBJETIVO é DISSEMINAR } \\
\text { ALTERNATIVAS DE MANEJO } \\
\text { APROPRIADO DA áGUA NA ZONA } \\
\text { RURAL ATRAVÉS DA IMPLANTAÇ }\end{array}$ \\
\hline $\begin{array}{c}\text { CONSÓRCIO DE } \\
\text { ESTUDOS, } \\
\text { RECUPERAÇÃO E } \\
\text { DESENVOLVIMENTO } \\
\text { DA BACIA DOS RIOS } \\
\text { SOROCABA E MÉDIO } \\
\text { TIETÊ- CERISO }\end{array}$ & $\begin{array}{c}\text { CONSÓRCIO } \\
\text { INTERMUNICIPAL }\end{array}$ & Cancelado & $16 / 12 / 2011$ & $355.978,00$ & 0 & $355.978,00$ & Sociedade Civil & Não reemb. & $\begin{array}{l}\text { Planej. e Gerenc. } \\
\text { dos Recs. Hídricos } \\
\text { (contratos) }\end{array}$ & 1932930 & PDC01 & 12 & $\begin{array}{c}\text { ESTE PROJETO PROPÕE A } \\
\text { CONTRATAÇÃO DE SERVIÇOS PARA } \\
\text { DAR CONTINUDADE DO PAANO DE } \\
\text { COMUNICAção E A COMP }\end{array}$ \\
\hline $\begin{array}{l}\text { PREFEITURA DO } \\
\text { MUNICIPIO DE TIETÊ }\end{array}$ & $\begin{array}{l}\text { ADMINISTRAÇÃ̃O } \\
\text { MUNICIPAL }\end{array}$ & Concluído & 03/06/2013 & $141.388,00$ & $22.439,51$ & $163.827,51$ & Município & Não reemb. & $\begin{array}{l}\text { Estudos/Projetos } \\
\text { (contratos) }\end{array}$ & 37450 & PDC01 & 5 & $\begin{array}{l}\text { OBTENção DE DADOS AMBIENTAIS } \\
\text { DO PONTO DE VISTA QUANTITATIVO } \\
\text { EQUALITATIVO, ASSIM COMO O } \\
\text { MAPEAMENTO, }\end{array}$ \\
\hline
\end{tabular}




\begin{tabular}{|c|c|c|c|c|c|c|c|c|c|c|c|c|c|}
\hline Nome do interessado & $\begin{array}{l}\text { Atividade principal do } \\
\text { interessado }\end{array}$ & $\begin{array}{c}\text { Situação do } \\
\text { emprendimento }\end{array}$ & $\begin{array}{c}\text { Data de } \\
\text { conclusão }\end{array}$ & Valor aprovado & $\begin{array}{c}\text { Valor de } \\
\text { contrapartida }\end{array}$ & Valor total & $\begin{array}{l}\text { Segmento do } \\
\text { interessado }\end{array}$ & Modalidade & $\begin{array}{l}\text { Benefício: } \\
\text { indicador }\end{array}$ & $\begin{array}{l}\text { População } \\
\text { beneficiada }\end{array}$ & PDC: sigla & $\begin{array}{c}\text { Tempo de } \\
\text { execução } \\
\text { (meses) }\end{array}$ & Descrição \\
\hline $\begin{array}{l}\text { PREFEITURA } \\
\text { MUNICIPALDE } \\
\text { TATUÚ }\end{array}$ & $\begin{array}{l}\text { PREFEITURA } \\
\text { MUNICIPAL }\end{array}$ & Cancelado & $13 / 11 / 2012$ & $119.959,00$ & $40.115,00$ & $160.074,00$ & Município & Não reemb. & $\begin{array}{l}\text { Recomposicĩão de } \\
\text { Mata Ciliar } \\
\text { (hectares) }\end{array}$ & 105000 & PDC09 & 27 & $\begin{array}{l}\text { SUA REVITALIZAÇ̃̃̃O JUSTIFICA-SE } \\
\text { PELO AUMENTO DA DISPONIBILIDADE } \\
\text { EQUALIDADE HÍDRICA DA BACIA DO } \\
\text { SOROC }\end{array}$ \\
\hline $\begin{array}{c}\text { ASSOCIAÇÃO } \\
\text { ECOAR FLORESTAL }\end{array}$ & $\begin{array}{c}\text { REALIZAÇÃO DE } \\
\text { PROJETOS } \\
\text { SOCIOAMBIENTAIS }\end{array}$ & Em execução & & $133.578,60$ & $33.859,00$ & $167.437,60$ & Sociedade Civil & Não reemb. & $\begin{array}{l}\text { Educação } \\
\text { Ambiental } \\
\text { (contratos) }\end{array}$ & 200 & PDC01 & 12 & $\begin{array}{c}\text { CONTRIBUIR PARA MELHORIA } \\
\text { AMBIENTAL NA BACIA } \\
\text { HIDROGRÁFICA DOS RIOS SOROCABA } \\
\text { E MÉDIO TIETÊ, POR MEIO D }\end{array}$ \\
\hline $\begin{array}{c}\text { SERVIÇO } \\
\text { AUTÔNOMO DE } \\
\text { ÁGUA EESGOTO DE } \\
\text { PORTO FELIZ (SAAE) }\end{array}$ & $\begin{array}{l}\text { PREFEITURA } \\
\text { MUNICIPAL }\end{array}$ & Concluído & $12 / 08 / 2013$ & $148.918,75$ & $102.078,32$ & $250.997,07$ & Município & Não reemb. & $\begin{array}{l}\text { Abastecimento de } \\
\text { Água (habitantes) }\end{array}$ & 3500 & $\mathrm{PDC} 05$ & 5 & $\begin{array}{l}\text { O PROJETO VISA A SUBSTITUIČ̃a DAS } \\
\text { REDES DE FERRO FUNDIDO, } \\
\text { CONTEMPLANDO A UTILIZAÇÃO DE } \\
\text { PVC, MAIS ADE }\end{array}$ \\
\hline $\begin{array}{l}\text { CONSÓRCIO DE } \\
\text { ESTUDOS, } \\
\text { RECUPERAÇÃOO } \\
\text { DESENVOLVIMENTO } \\
\text { DA BACIA DOS RIOS } \\
\text { SOROCABA E MÉDIO } \\
\text { TIETÊ- CERISO }\end{array}$ & $\begin{array}{c}\text { CONSŚRCIO } \\
\text { INTERMUNICIPAL }\end{array}$ & Concluído & $15 / 07 / 2015$ & $101.395,00$ & $27.001,00$ & $128.396,00$ & Sociedade Civil & Não reemb. & $\begin{array}{l}\text { Educacãão } \\
\text { Ambiental } \\
\text { (contratos) }\end{array}$ & 600 & PDC01 & 18 & $\begin{array}{c}\text { CONSCIENTIZAR A COMUNIDADE } \\
\text { RESIDENTE NA APA ITUPARARANGA } \\
\text { QUANTO à IMPORTâNCIA AMBIENTAL } \\
\text { DA REGIãO EM }\end{array}$ \\
\hline $\begin{array}{l}\text { PREFEITURA } \\
\text { MUNICIPAL DA } \\
\text { ESTÂNCIA } \\
\text { TURÍSTICA DE } \\
\text { IBIÚNA }\end{array}$ & $\begin{array}{l}\text { PREFEITURA } \\
\text { MUNICIPAL }\end{array}$ & Cancelado & $16 / 12 / 2011$ & $160.442,44$ & $43.008,86$ & $203.451,30$ & Município & Não reemb. & $\begin{array}{l}\text { Estudos/Projetos } \\
\text { (contratos) }\end{array}$ & 500 & PDC09 & 18 & $\begin{array}{c}\text { ELABORAR O PROJETO EXECUTIVO } \\
\text { PARA RECUPERAçãO FLORESTAL DAS } \\
\text { NASCENTES PRIORITáRIAS à CONEXãO } \\
\text { DE FRAG }\end{array}$ \\
\hline $\begin{array}{c}\text { CONSÓRCIO DE } \\
\text { ESTUDOS, } \\
\text { RECUPERAÇÃ̃OE } \\
\text { DESENVOLVIMENTO } \\
\text { DA BACIA DOS RIOS } \\
\text { SOROCABA E MÉDIO } \\
\text { TIETÊ- CERISO }\end{array}$ & $\begin{array}{c}\text { CONSÓRCIO } \\
\text { INTERMUNICIPAL }\end{array}$ & Cancelado & $14 / 05 / 2010$ & 0 & 0 & 0 & Sociedade Civil & Não reemb. & $\begin{array}{l}\text { Estudos/Projetos } \\
\text { (contratos) }\end{array}$ & 2000000 & PDC01 & 12 & $\begin{array}{l}\text { BANCO DE DADOS DE PROJETO } \\
\text { FEHIDRO E DEFINIÇ̃̃O DE } \\
\text { PROCEDIMENTOS DE VALIAÇÃ O E } \\
\text { TRAMITAÇÃO DE PROJETOS }\end{array}$ \\
\hline $\begin{array}{l}\text { CONSÓRCIO DE } \\
\text { ESTUDOS, } \\
\text { RECUPERAÇÃOO } \\
\text { DESENVOLVIMENTO } \\
\text { DA BACIA DOS RIOS } \\
\text { SOROCABA E MÉDIO } \\
\text { TIETÊ- CERISO }\end{array}$ & $\begin{array}{c}\text { CONSÓRCIO } \\
\text { INTERMUNICIPAL }\end{array}$ & Concluído & $12 / 09 / 2013$ & $161.000,00$ & 0 & $161.000,00$ & Sociedade Civil & Não reemb. & Outros (contratos) & 2000000 & PDC01 & 10 & $\begin{array}{l}\text { 1. PROMOVER MATERIAIS DE APOIO } \\
\text { PARA ENTIDADES EDUCACIONAIS, } \\
\text { ASSEGURAR AS AçõES DA FABH-SMT, } \\
\text { COMO SEC }\end{array}$ \\
\hline $\begin{array}{c}\text { PREFEITURA } \\
\text { MUNICIPALDE } \\
\text { CAPELA DO ALTO }\end{array}$ & $\begin{array}{l}\text { PREFEITURA } \\
\text { MUNICIPAL }\end{array}$ & Concluído & $15 / 05 / 2014$ & $180.000,00$ & $60.166,18$ & $240.166,18$ & Município & Não reemb. & $\begin{array}{l}\text { Coleta e } \\
\text { Tratamento de } \\
\text { Esgotos } \\
\text { (habitantes) }\end{array}$ & 420 & $\mathrm{PDC} 03$ & 6 & $\begin{array}{l}\text { RESOLVER O PROBLEMA DE } \\
\text { ESGOTAMENTO SANITáRIO DO } \\
\text { BAIRRO }\end{array}$ \\
\hline $\begin{array}{l}\text { PREFEITURA } \\
\text { MUNIIIPALDE } \\
\text { VARGEM GRANDE } \\
\text { PAUUISTA }\end{array}$ & $\begin{array}{l}\text { PREFEITURA } \\
\text { MUNICIPAL }\end{array}$ & Cancelado & $14 / 05 / 2010$ & 0 & 0 & 0 & Munić́pio & Não reemb. & $\begin{array}{l}\text { Trat. e Disposição } \\
\text { de Lixo - Obras } \\
\text { (habitantes) }\end{array}$ & 48650 & $\mathrm{PDC} 03$ & 8 & $\begin{array}{l}\text { ELIMINAR DE VEZ A POSSIBILIDADE } \\
\text { DE USO DA áREA COMO DEPŚSITO DE } \\
\text { LIXO E BUSCAR POR MEIO DO } \\
\text { TRATAMENTO }\end{array}$ \\
\hline $\begin{array}{c}\text { PREFEITURA } \\
\text { MUNICIPALDE } \\
\text { ARAÇARIGUAMA }\end{array}$ & SERVIÇO PÚBLICO & Concluído & 26/08/2015 & $143.520,00$ & $33.900,48$ & $177.420,48$ & Município & Não reemb. & Outros (contratos) & 9620 & $\mathrm{PDC} 03$ & 12 & $\begin{array}{l}\text { REDUZIR A CARGA POLUIDORA NA } \\
\text { áGUA GERADA PELO USO } \\
\text { INADEQUADO DO SISTEMA DE } \\
\text { AFASTAMENTO DE ESGOTO, CO }\end{array}$ \\
\hline $\begin{array}{l}\text { COOPERATIVA DE } \\
\text { RECICLAGEM } \\
\text { RENASCER }\end{array}$ & $\begin{array}{l}\text { COLETA DE } \\
\text { MATERIAIS } \\
\text { RECICLADOS }\end{array}$ & Cancelado & 14/05/2010 & 0 & 0 & 0 & Sociedade Civil & Não reemb. & $\begin{array}{l}\text { Trat.e Disposição } \\
\text { de Lixo - Obras } \\
\text { (habitantes) }\end{array}$ & 45000 & $\mathrm{PDC} 03$ & 10 & $\begin{array}{c}\text { O OBJETIVO DESTE PROJETOé } \\
\text { AUMENTAR O NúMERO DE FAMILIAS } \\
\text { ATENDIDAS, ATINGINDO UMA META } \\
\text { DE } 50 \text { NO PERí }\end{array}$ \\
\hline
\end{tabular}




\begin{tabular}{|c|c|c|c|c|c|c|c|c|c|c|c|c|c|}
\hline Nome do interessado & $\begin{array}{l}\text { Atividade principal do } \\
\text { interessado }\end{array}$ & $\begin{array}{l}\text { Situacacão do } \\
\text { empreendimento }\end{array}$ & $\begin{array}{l}\text { Data de } \\
\text { conclusão }\end{array}$ & Valor aprovado & $\begin{array}{c}\text { Valor de } \\
\text { contrapartida }\end{array}$ & Valor total & $\begin{array}{l}\text { Segmento do } \\
\text { interessado }\end{array}$ & Modalidade & $\begin{array}{l}\text { Benefício: } \\
\text { indicador }\end{array}$ & $\begin{array}{c}\text { População } \\
\text { beneficiada }\end{array}$ & PDC: sigla & $\begin{array}{l}\text { Tempo de } \\
\text { execução } \\
\text { (meses) }\end{array}$ & Descrição \\
\hline $\begin{array}{l}\text { FUNDIBIO - } \\
\text { FUNDAçãO DO } \\
\text { INSTITTOO DE } \\
\text { BIOCIêNCIAS }\end{array}$ & $\begin{array}{c}\text { COLABORAR EM } \\
\text { PROGRAMAS DE } \\
\text { DESENVOLVIMENTO } \\
\text { ECONôMICO E } \\
\text { SOCIALA SEREM } \\
\text { ESTABELECIDOS } \\
\text { COM O INSTITUTO } \\
\text { D }\end{array}$ & Emexecução & & $143.202,00$ & $36.551,75$ & $179.753,75$ & Sociedade Civil & Não reemb. & $\begin{array}{l}\text { Educação } \\
\text { Ambiental } \\
\text { (contratos) }\end{array}$ & 119000 & PDC01 & 15 & $\begin{array}{l}\text { CONTRIBUIR PARA CONSOLIDAR AS } \\
\text { CONDIcõES DE CONSERAçãO, } \\
\text { MANEJO ERECUPERAçãO DOS } \\
\text { AMBIENTES NATURAIS }\end{array}$ \\
\hline $\begin{array}{c}\text { ASSOCIAÇ̃̃O } \\
\text { ECOAR FLORESTAL }\end{array}$ & $\begin{array}{l}\text { REALIZAÇÃO DE } \\
\text { PROJETOS } \\
\text { SOCIOAMBIENTAIS }\end{array}$ & Emexecução & - & $123.947,00$ & $30.713,20$ & $154.660,20$ & Sociedade Civil & Não reemb. & $\begin{array}{l}\text { Educação } \\
\text { Ambiental } \\
\text { (contratos) }\end{array}$ & 80 & PDC01 & 12 & $\begin{array}{c}\text { FORMAR } 80 \text { AGENTES DE } \\
\text { DESENVOLVIMENTO PARA A GESTão } \\
\text { COMPARTLLHADA EPARA A } \\
\text { IMPLEMENTAçãO DE PROCESSOS }\end{array}$ \\
\hline $\begin{array}{l}\text { IPESA - INSTITUTO } \\
\text { DE PROJETOS E } \\
\text { PESQUISAS } \\
\text { SOCIOAMBIENTAIS }\end{array}$ & MEIO AMBIENTE & Concluído & $15 / 01 / 2014$ & $168.871,50$ & $41.448,51$ & $210.320,01$ & Sociedade Civil & Não reemb. & $\begin{array}{l}\text { Estudos/Projetos } \\
\quad \text { (contratos) }\end{array}$ & 15000 & PDC01 & 12 & $\begin{array}{c}\text { PRODUZIR MATERIAL CARTOGRáFICO } \\
\text { EM ESCALA DE DETALHE (1:10.000) } \\
\text { PARA SUBSIDIAR A RECUPERAção DE } \\
\text { áREAS }\end{array}$ \\
\hline $\begin{array}{l}\text { PREFEITURA } \\
\text { MUNICIPALDE } \\
\text { BOTUCATU }\end{array}$ & $\begin{array}{l}\text { PREFEITURA } \\
\text { MUNICIPAL }\end{array}$ & Cancelado & $16 / 12 / 2011$ & $149.897,88$ & $43.471,00$ & $193.368,88$ & Município & Não reemb. & $\begin{array}{l}\text { Recomposição de } \\
\text { Mata Ciliar } \\
\text { (hectares) }\end{array}$ & 120000 & PDC09 & 30 & $\begin{array}{l}\text { A RECUPERAç̃o DA MATA CLLIAR DO } \\
\text { CóRREGO DO TENENTE PARA } \\
\text { MELHORAR AS SUAS CONDIçỗES } \\
\text { HiDRICAS E RESTAB }\end{array}$ \\
\hline $\begin{array}{c}\text { SERVIÇO } \\
\text { AUTÔNOMO DE } \\
\text { ÁGUA EESGOTO DE } \\
\text { CERQUILHO }\end{array}$ & $\begin{array}{l}\text { SERVIÇO DE } \\
\text { SANEAMENTO } \\
\text { BÁSICO }\end{array}$ & Concluído & 02/01/2012 & $180.000,00$ & $224.776,77$ & $404.776,77$ & Município & Não reemb. & $\begin{array}{l}\text { Coleta e } \\
\text { Tratamento de } \\
\text { Esgotos } \\
\text { (habitantes) }\end{array}$ & 38192 & $\mathrm{PDC} 03$ & 7 & $\begin{array}{l}\text { A IMPLANTAçãO DO SISTEMA DE } \\
\text { DESáGUE DE LODO OBJETIVA EQUIPAR } \\
\text { A ESTAção DE TRATAMENTO DE } \\
\text { ESGOTO, DENO }\end{array}$ \\
\hline $\begin{array}{c}\text { SERVIÇO } \\
\text { AUTÔNOMO } \\
\text { MUNICIPAL DE } \\
\text { ÁGUA EESGOTO DE } \\
\text { TIETÊE- SAMAE }\end{array}$ & $\begin{array}{l}\text { SANEAMENTO } \\
\text { PÚBLICO }\end{array}$ & Concluído & 29/07/2015 & $117.388,93$ & $30.577,00$ & $147.965,93$ & Município & Não reemb. & $\begin{array}{l}\text { Abastecimento de } \\
\text { Água (habitantes) }\end{array}$ & 36211 & PDC05 & 6 & $\begin{array}{c}\text { O OBJETO DO PRESENTE TRABALHO } \\
\text { A SETORIZAçãO COM RECURSOS } \\
\text { PRóPRIOS ECONTRAAçãO DE } \\
\text { EMPRESA ESPECIA }\end{array}$ \\
\hline $\begin{array}{l}\text { PREFEITURA } \\
\text { MUNICIPALDE } \\
\text { IPERÓ }\end{array}$ & $\begin{array}{l}\text { PREFEITURA } \\
\text { MUNICIPAL }\end{array}$ & Emexecução & & $180.000,00$ & $83.110,77$ & $263.110,77$ & Município & Não reemb. & $\begin{array}{c}\text { Coleta e } \\
\text { Tratamento de } \\
\text { Esgotos } \\
\text { (habitantes) }\end{array}$ & 310 & $\mathrm{PDC} 03$ & 10 & $\begin{array}{l}\text { RESOLVER O PROBLEMA DE } \\
\text { AFASTAMENTO DO ESGOTO } \\
\text { SANITáRIO DO BAIRRO }\end{array}$ \\
\hline $\begin{array}{l}\text { PREFEITURA } \\
\text { MUNICIPALDE } \\
\text { MAIRINQUE }\end{array}$ & $\begin{array}{l}\text { PREFEITURA } \\
\text { MUNICIPAL }\end{array}$ & Concluído & $23 / 10 / 2013$ & $85.923,94$ & $21.480,48$ & $107.404,42$ & Município & Não reemb. & $\begin{array}{l}\text { Educação } \\
\text { Ambiental } \\
\text { (contratos) }\end{array}$ & 18000 & PDC01 & 10 & $\begin{array}{c}\text { OS OBJETIVOS A SEREM ALCANçADOS } \\
\text { SERão: DEENENVOLER A INTEGRAçã̃, } \\
\text { CONSCIENTIZAçãO E SENSIBLIZAção } \\
\text { DE }\end{array}$ \\
\hline $\begin{array}{l}\text { SOS } \\
\text { ITUPARARANGA - } \\
\text { ORGANIZAÇÃO DA } \\
\text { SOCIEDADECIVIL DE } \\
\text { INTERESSE PÚBLICO }\end{array}$ & $\begin{array}{l}\text { PROTEÇÃO DOS } \\
\text { RECURSOS } \\
\text { HÍDRICOS E } \\
\text { PROJETOS DE } \\
\text { EDUCAÇÃO } \\
\text { AMBIENTAL }\end{array}$ & Concluído & 02/02/2016 & $65.768,00$ & $33.946,00$ & $99.714,00$ & Sociedade Civil & Não reemb. & $\begin{array}{l}\text { Educação } \\
\text { Ambiental } \\
\text { (contratos) }\end{array}$ & 2300 & PDC01 & 12 & $\begin{array}{l}\text { O OBJETIVO PRINCIPAL DO PROJETO é } \\
\text { PROMOVER UMA CAMPANHA } \\
\text { VOLTADA à CONSCAENTZAÇãO DOS } \\
\text { PRODUTORES AGR }\end{array}$ \\
\hline $\begin{array}{l}\text { PREFEITURA } \\
\text { MUNICIPAL DA } \\
\text { ESTÂNCIA } \\
\text { TURÍ́TIICA DE } \\
\text { IBIÚNA }\end{array}$ & $\begin{array}{l}\text { PREFEITURA } \\
\text { MUNICIPAL }\end{array}$ & Cancelado & 01/07/2011 & 0 & 0 & 0 & Município & Não reemb. & $\begin{array}{l}\text { Estudos//rojetos } \\
\text { (contratos) }\end{array}$ & 73900 & $\mathrm{PDC} 03$ & 12 & $\begin{array}{c}\text { O OBJETIVO PRINCIPAL DESTAS } \\
\text { ATIVIDADES, CRNFORME O MANUAL } \\
\text { DE GERENCIAMENTO DE ÁREAS } \\
\text { CONTAMINADAS (CE }\end{array}$ \\
\hline $\begin{array}{c}\text { AÇÃO DA } \\
\text { CIDADANA - } \\
\text { COMITÊEIBIÚNA/SP }\end{array}$ & $\begin{array}{l}\text { PROMOVER O BEM } \\
\text { DE TODOS SEM } \\
\text { PRECONCEITOS, } \\
\text { DEFENDER } \\
\text { INTERESSES } \\
\text { COLETIVS, } \\
\text { COMBATER A } \\
\text { EXCLUSÃO SOCIAL }\end{array}$ & Concluído & $16 / 08 / 2016$ & $137.124,30$ & $19.305,00$ & $156.429,30$ & Sociedade Civil & Não reemb. & $\begin{array}{l}\text { Educação } \\
\text { Ambiental } \\
\text { (contratos) }\end{array}$ & 2283 & PDC01 & 12 & $\begin{array}{c}\text { O PROJETO TEM COMO OBJETIVO } \\
\text { GERAL PROPOR MEDIDAS E AÇÕES } \\
\text { QUE ESTIMULEM A MUDANÇA DE } \\
\text { COMPORTAMENTO E }\end{array}$ \\
\hline $\begin{array}{l}\text { IPESA - INSTITUTO } \\
\text { DE PROJETOS E } \\
\text { PESQUISAS } \\
\text { SOCIOAMBIENTAIS }\end{array}$ & MEIO AMBIENTE & Emexecução & & $168.871,50$ & $40.961,38$ & $209.832,88$ & Sociedade Civil & Não reemb. & $\begin{array}{l}\text { Estudos/Projetos } \\
\text { (contratos) }\end{array}$ & 15000 & PDC01 & 12 & $\begin{array}{c}\text { PRODUZIR MATERIAL } \\
\text { CARTOGRÁFICO EM ESCALA DE } \\
\text { DETALHE }(1: 10.000) \text { PARA SUBSIDIAR A } \\
\text { RECUPERAçã̃o DE ÁREAS }\end{array}$ \\
\hline
\end{tabular}




\begin{tabular}{|c|c|c|c|c|c|c|c|c|c|c|c|c|c|}
\hline Nome do interessado & $\begin{array}{l}\text { Atividade principal do } \\
\text { interessado }\end{array}$ & $\begin{array}{c}\text { Situação do } \\
\text { empreendimento }\end{array}$ & $\begin{array}{l}\text { Data de } \\
\text { conclusão }\end{array}$ & Valor aprovado & $\begin{array}{l}\text { Valor de } \\
\text { contrapartida }\end{array}$ & Valor total & $\begin{array}{l}\text { Segmento do } \\
\text { interessado }\end{array}$ & Modalidade & $\begin{array}{l}\text { Benefíicio: } \\
\text { indicador }\end{array}$ & $\begin{array}{l}\text { População } \\
\text { beneficiada }\end{array}$ & PDC: sigla & $\begin{array}{l}\text { Tempo de } \\
\text { execução } \\
\text { (meses) }\end{array}$ & Descrição \\
\hline $\begin{array}{c}\text { PREFEITURA } \\
\text { MUNICIPALDE } \\
\text { CAPELA DO ALTO }\end{array}$ & $\begin{array}{l}\text { PREFEITURA } \\
\text { MUNICIPAL }\end{array}$ & Cancelado & 13/11/2012 & $180.000,00$ & $60.228,86$ & $240.228,86$ & Município & Não reemb. & $\begin{array}{l}\text { Coleta e } \\
\text { Tratamento de } \\
\text { Esgotos } \\
\text { (habitantes) }\end{array}$ & 400 & PDC03 & 6 & $\begin{array}{c}\text { ALCANÇAR 100\% DE ESGOTO } \\
\text { TRATADO NO MUNICíPIO DE CAPELA } \\
\text { DO ALTO }\end{array}$ \\
\hline $\begin{array}{l}\text { PREFEITURA } \\
\text { MUNICIPAL DE } \\
\text { CONCHAS }\end{array}$ & $\begin{array}{l}\text { PREFEITURA } \\
\text { MUNICIPAL }\end{array}$ & Cancelado & 01/07/2011 & 0 & 0 & 0 & Município & Não reemb. & $\begin{array}{l}\text { Estudos/Projetos } \\
\text { (contratos) }\end{array}$ & 16274 & PDC05 & 12 & $\begin{array}{c}\text { O PROJETO TEM POR OBJETIVO } \\
\text { GARANTIR QUALITATIVAMENTEE } \\
\text { QUANTITATIVAMENTE A PRODUÇÃO } \\
\text { DE ÁGUA VISANDO }\end{array}$ \\
\hline $\begin{array}{l}\text { PREFEITURA } \\
\text { MUNICIPALDE } \\
\text { MAIRINQUE }\end{array}$ & $\begin{array}{l}\text { PREFEITURA } \\
\text { MUNICIPAL }\end{array}$ & Concluído & 09/05/2013 & $148.000,00$ & $37.000,00$ & $185.000,00$ & Município & Não reemb. & $\begin{array}{l}\text { Estudos/Projetos } \\
\text { (contratos) }\end{array}$ & 15000 & PDC01 & 12 & $\begin{array}{c}\text { O OBJETIVO PRINCIPAL DESSE } \\
\text { PROJETO É REALIZAR UM } \\
\text { DIAGNóSTICO DO MEIO FISICO DE } \\
\text { TODA ÁREA DO MUNICIPI }\end{array}$ \\
\hline $\begin{array}{l}\text { PREFEITURA } \\
\text { MUNICIPALDE } \\
\text { QUADRA }\end{array}$ & $\begin{array}{l}\text { PREFEITURA } \\
\text { MUNICIPAL }\end{array}$ & Cancelado & 25/04/2012 & $178.146,88$ & $5.507,69$ & $183.654,57$ & Município & Não reemb. & $\begin{array}{l}\text { Trat.e Disposição } \\
\text { de Lixo - Obras } \\
\text { (habitantes) }\end{array}$ & 2800 & PDC03 & 7 & $\begin{array}{c}\text { REDUZIR O EFEITO CONTAMINANTE } \\
\text { DO SOLO E DA ÁGUA NA REGIÃO DO } \\
\text { ATERRO SANITÁRIO, AUMENTANDO } \\
\text { A VIDA ÚTI }\end{array}$ \\
\hline $\begin{array}{c}\text { SERVIÇO } \\
\text { AUTÔNOMO } \\
\text { MUNICIPAL DE } \\
\text { ÁGUA E ESGOTO DE } \\
\text { TIETE- - SAMAE }\end{array}$ & $\begin{array}{l}\text { SANEAMENTO } \\
\text { PÚBLICO }\end{array}$ & Concluído & 01/06/2016 & $135.676,45$ & $28.991,20$ & $164.667,65$ & Município & Não reemb. & $\begin{array}{l}\text { Abastecimento de } \\
\text { Água (habitantes) }\end{array}$ & 36211 & PDC05 & 7 & $\begin{array}{c}\text { O OBJETO DO PRESENTE TRABALHO É } \\
\text { A CONTRATAçãO DE EMPRESA } \\
\text { ESPECIALIZADA PARA O } \\
\text { FORNECIMENTO, INSTALAÇ }\end{array}$ \\
\hline $\begin{array}{c}\text { SERVIÇO } \\
\text { AUTÔNOMO DE } \\
\text { ÁGUA EESGOTO DE } \\
\text { VOTORANTIM - } \\
\text { SAAE }\end{array}$ & $\begin{array}{l}\text { PREFEITURA } \\
\text { MUNICIPAL }\end{array}$ & Em execução & - & $170.430,00$ & $8.950,00$ & $179.380,00$ & Município & Não reemb. & $\begin{array}{l}\text { Abastecimento de } \\
\text { Água (habitantes) }\end{array}$ & 26000 & PDC05 & 8 & 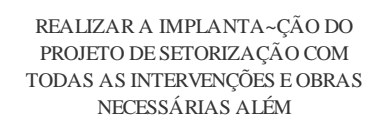 \\
\hline $\begin{array}{c}\text { ESCRITÓRIO DE } \\
\text { DESENVOLVIMENTO } \\
\text { RURAL DE } \\
\text { BOTUCATU - CATI }\end{array}$ & $\begin{array}{c}\text { ASSISTÊNCIA } \\
\text { TÉCNICA E } \\
\text { EXTENSÃO RURAL }\end{array}$ & Cancelado & 13/09/2012 & $41.315,05$ & $62.560,20$ & $103.875,25$ & Estado & Não reemb. & $\begin{array}{l}\text { Planej.e Gerenc. } \\
\text { dos Recs. Hídricos } \\
\text { (contratos) }\end{array}$ & 1300 & PDC01 & 12 & $\begin{array}{l}\text { DIAGNOSTICAR A SITUAÇÃO ATUAL } \\
\text { DOS RECURSOS NATURAIS NA } \\
\text { MICROBACIA DO ALTO DO RIO } \\
\text { CAPIVARA ATÉO PARQ }\end{array}$ \\
\hline $\begin{array}{l}\text { PREFEITURA } \\
\text { MUNICIPALDE } \\
\text { TATUÍ }\end{array}$ & $\begin{array}{l}\text { PREFEITURA } \\
\text { MUNICIPAL }\end{array}$ & Cancelado & 01/07/2011 & 0 & 0 & 0 & Município & Não reemb. & $\begin{array}{l}\text { Estudos/Projetos } \\
\text { (contratos) }\end{array}$ & 260000 & PDC03 & 3 & $\begin{array}{c}\text { CONTRATAÇÃO DE SERVIÇOS DE } \\
\text { ENGENHARIA PARA ELABORAÇÃO DE } \\
\text { PROJETO PARA ENCERRAMENTO DA } \\
\text { ÁREA DE LIXÃO, }\end{array}$ \\
\hline $\begin{array}{l}\text { PREFEITURA } \\
\text { MUNIIIPALDE } \\
\text { IPERÓ }\end{array}$ & $\begin{array}{l}\text { PREFEITURA } \\
\text { MUNICIPAL }\end{array}$ & Concluído & 04/10/2013 & $177.932,86$ & $139.567,17$ & $317.500,03$ & Município & Não reemb. & $\begin{array}{l}\text { Coleta e } \\
\text { Tratamento de } \\
\text { Esgotos } \\
\text { (habitantes) }\end{array}$ & 4327 & $\mathrm{PDC}_{3}$ & 5 & $\begin{array}{c}\text { A IMPLANTAç̃o DO } \\
\text { EMPREENDIMENTO TEM COMO } \\
\text { OBJETIVO MELHORAR A SAÚDE } \\
\text { PÚBLICA DA COMUNIDADE, } \\
\text { INCLUINDO }\end{array}$ \\
\hline $\begin{array}{l}\text { PREFEITURA } \\
\text { MUNICIPALDE } \\
\text { PIEDADE }\end{array}$ & $\begin{array}{l}\text { PREFEITURA } \\
\text { MUNICIPAL }\end{array}$ & Em execução & - & $154.697,96$ & $28.000,00$ & $182.697,96$ & Município & Não reemb. & $\begin{array}{l}\text { Planej. e Gerenc. } \\
\text { dos Recs. Hídricos } \\
\text { (contratos) }\end{array}$ & 26000 & PDC01 & 12 & $\begin{array}{l}\text { IDENTIFICAR E DELIMITAR AS SUB- } \\
\text { BACIAS DO RIO PIRAPORA E SARAPUí, } \\
\text { NO ÂMBITO DO MUNICIIPIO DE } \\
\text { PIEDADE; }\end{array}$ \\
\hline $\begin{array}{l}\text { CONSÓRCIO DE } \\
\text { ESTUDOS, } \\
\text { RECUPERAÇÃO E } \\
\text { DESENVOLVIMENTO } \\
\text { DA BACIA DOS RIOS }\end{array}$ & $\begin{array}{c}\text { CONSÓRCIO } \\
\text { INTERMUNICIPAL }\end{array}$ & Cancelado & 01/08/2012 & $360.000,00$ & 0 & $360.000,00$ & Sociedade Civil & Não reemb. & $\begin{array}{l}\text { Planej.e Gerenc. } \\
\text { dos Recs. Hídricos } \\
\text { (contratos) }\end{array}$ & 1600000 & PDC01 & 12 & $\begin{array}{c}\text { ESTE PROJETO PROPōE A } \\
\text { CONTRATAção DE SERVIçOS PARA } \\
\text { DAR CONTINUIDADE DO PLANO DE } \\
\text { COMUNICAçãO EA COMP }\end{array}$ \\
\hline
\end{tabular}




\begin{tabular}{|c|c|c|c|c|c|c|c|c|c|c|c|c|c|}
\hline Nome do interessado & $\begin{array}{l}\text { Atividade principal do } \\
\text { interessado }\end{array}$ & $\begin{array}{l}\text { Situação do } \\
\text { empreendimento }\end{array}$ & $\begin{array}{c}\text { Data de } \\
\text { conclusão }\end{array}$ & Valor aprovado & $\begin{array}{c}\text { Valor de } \\
\text { contrapartida }\end{array}$ & Valor total & $\begin{array}{l}\text { Segmento do } \\
\text { interessado }\end{array}$ & Modalidade & $\begin{array}{l}\text { Benefício: } \\
\text { indicador }\end{array}$ & $\begin{array}{l}\text { População } \\
\text { beneficiada }\end{array}$ & PDC: sigla & $\begin{array}{l}\text { Tempo de } \\
\text { execução } \\
\text { (meses) }\end{array}$ & Descrição \\
\hline $\begin{array}{c}\text { CONSÓRCIO DE } \\
\text { ESTUDOS, } \\
\text { RECUPERAÇÃ̃OE } \\
\text { DESENVOLVIMENTO } \\
\text { DA BACIA DOS RIOS } \\
\text { SOROCABA E MÉDIO } \\
\text { TIETÊ- CERISO }\end{array}$ & $\begin{array}{c}\text { CONSÓRCIO } \\
\text { INTERMUNICIPAL }\end{array}$ & Cancelado & 13/11/2012 & $700.000,00$ & 0 & $700.000,00$ & Sociedade Civil & Não reemb. & $\begin{array}{l}\text { Planej.e Gerenc. } \\
\text { dos Recs. Hidricos } \\
\text { (contratos) }\end{array}$ & 1800000 & PDC01 & 15 & $\begin{array}{l}\text { PROPOR AS PRINCIPAIS DIRETRIZES, } \\
\text { ESTRATéGIAS DE EXECUção E } \\
\text { PRODUTOS BáSICOS A SEREM } \\
\text { CONSIDERADOS EO }\end{array}$ \\
\hline $\begin{array}{l}\text { UNIVERSIDADE } \\
\text { ESTADUAL } \\
\text { PAULISTA JULIO DE } \\
\text { MESQUITA FILHO- } \\
\text { UNESP CAMPUS } \\
\text { EXPERIMENTALDE } \\
\text { SOROCABA }\end{array}$ & $\begin{array}{l}\text { UNIVERSIDADE } \\
\text { PÚBLICA }\end{array}$ & Cancelado & 16/03/2016 & $119.157,68$ & $13.442,82$ & $132.600,50$ & Estado & Não reemb. & $\begin{array}{l}\text { Educação } \\
\text { Ambiental } \\
\text { (contratos) }\end{array}$ & 3000 & PDC01 & 12 & $\begin{array}{l}\text { O PRESENTE PROJETO ENQUADRA-SE } \\
\text { INTEGRALMENTE NO REFERIDO PDC-8, } \\
\text { TENDO EM VISTA QUEA SUA } \\
\text { PROMOção AO }\end{array}$ \\
\hline $\begin{array}{l}\text { FUNDAÇ̃̃̃O DE } \\
\text { APOIO A PESQUISA } \\
\text { AGRí́COLA - } \\
\text { FUNDAG }\end{array}$ & $\begin{array}{l}\text { SUPORTEE APOIO À } \\
\text { PESQUISA E } \\
\text { DESENVOLVIMENTO } \\
\text { EM TECNOLOGIA E } \\
\text { RECURSOS } \\
\text { HÍDRICOS }\end{array}$ & Cancelado & 08/10/2013 & $179.660,00$ & $111.600,00$ & $291.260,00$ & Sociedade Civil & Não reemb. & $\begin{array}{c}\text { Estudos/Projetos } \\
\text { (contratos) }\end{array}$ & 2200000 & PDC01 & 12 & $\begin{array}{l}\text { DENTRO DOS PROGRAMAS DA } \\
\text { ORGANIZAç̃̃ METEOROĹGGICA } \\
\text { MUNDIAL, PRAA SEFAZER FRENTE } \\
\text { AOS PROCESSOS DE AQU }\end{array}$ \\
\hline $\begin{array}{c}\text { AÇ̃̃̃O DA } \\
\text { CIDADANIA - } \\
\text { COMTÊE IBIUUNAA/SP }\end{array}$ & $\begin{array}{c}\text { PROMOVER O BEM } \\
\text { DE TODOS SEM } \\
\text { PRECONCEITOS, } \\
\text { DEFENDER } \\
\text { INTERESSES } \\
\text { COLETIVOS, } \\
\text { COMBATER A } \\
\text { EXCLUSÃO SOCIAL }\end{array}$ & Cancelado & 04/12/2013 & $181.078,30$ & $22.086,70$ & $203.165,00$ & Sociedade Civil & Não reemb. & $\begin{array}{l}\text { Educação } \\
\text { Ambiental } \\
\text { (contratos) }\end{array}$ & 3203 & PDC01 & 12 & $\begin{array}{l}\text { TRATAR O SANEAMENTO COM UMA } \\
\text { ABORDAGEM SOCIOAMBENTAL QUE } \\
\text { DEVERá PROMEVER NãO Só A SAúDE } \\
\text { DO HOMEM, MA }\end{array}$ \\
\hline $\begin{array}{c}\text { SERVIÇO } \\
\text { AUTOONOMO DE } \\
\text { ÁGUA EESGOTO DE } \\
\text { PORTO FELIZ (SAAE) }\end{array}$ & $\begin{array}{l}\text { PREFEITURA } \\
\text { MUNICIPAL }\end{array}$ & Cancelado & 04/12/2013 & $395.014,40$ & $53.865,60$ & $448.880,00$ & Município & Não reemb. & $\begin{array}{l}\text { Abastecimento de } \\
\text { Água (habitantes) }\end{array}$ & 42300 & PDC05 & 3 & $\begin{array}{c}\text { O OBJETIVO DA AçãO PROPOSTA é DE } \\
\text { OBTER MAIOR CONTROLE E } \\
\text { CONFIABILDADE QUANTO àS PERDAS } \\
\text { APARENTES ( } \mathrm{N}\end{array}$ \\
\hline $\begin{array}{c}\text { SERVIÇO } \\
\text { AUTÔNOMO DE } \\
\text { ÁGUA EESGOTO DE } \\
\text { PORTO FELIZ (SAAE) }\end{array}$ & $\begin{array}{l}\text { PREFEITURA } \\
\text { MUNICIPAL }\end{array}$ & Concluído & $15 / 12 / 2014$ & $396.000,00$ & $42.300,00$ & $438.300,00$ & Município & Não reemb. & Outros (contratos) & 18000 & PDC05 & 4 & $\begin{array}{c}\text { O OBJETIVO DA AçãO PROPOSTA é DE } \\
\text { OBTER MAIOR CONTROLE E } \\
\text { CONFIABILIDADE QUANTO àS PERDAS } \\
\text { APARENTES (N }\end{array}$ \\
\hline $\begin{array}{c}\text { SOS } \\
\text { ITUPARARANGA - } \\
\text { ORGANIZAÇÃO DA } \\
\text { SOCIEDADECIVIL DE } \\
\text { INTERESSE PÚBLICO }\end{array}$ & $\begin{array}{l}\text { PROTEÇ̃̃O DOS } \\
\text { RECURSOS } \\
\text { HÍDRICOS E } \\
\text { PROJETOS DE } \\
\text { EDUCAÇÃO } \\
\text { AMBIENTAL }\end{array}$ & Emexecução & - & $209.940,00$ & $29.270,00$ & $239.210,00$ & Sociedade Civil & Não reemb. & $\begin{array}{l}\text { Educação } \\
\text { Ambiental } \\
\text { (contratos) }\end{array}$ & 147470 & PDC01 & 18 & $\begin{array}{l}\text { OBJETIVO: SENSIBILIZAR OS ATORES } \\
\text { LOCAIS SOBRE OS IMPACTOS } \\
\text { AMBIENTAIS QUECOMPROMETEM A } \\
\text { QUALIDADE DA }\end{array}$ \\
\hline
\end{tabular}




\begin{tabular}{|c|c|c|c|c|c|c|c|c|c|c|c|c|c|}
\hline Nome do interessado & $\begin{array}{l}\text { Atividade principal do } \\
\text { interessado }\end{array}$ & $\begin{array}{l}\text { Situação do } \\
\text { empreendimento }\end{array}$ & $\begin{array}{l}\text { Data de } \\
\text { conclusão }\end{array}$ & Valor aprovado & $\begin{array}{c}\text { Valor de } \\
\text { contrapartida }\end{array}$ & Valor total & $\begin{array}{l}\text { Segmento do } \\
\text { interessado }\end{array}$ & Modalidade & $\begin{array}{l}\text { Benefíicio: } \\
\text { indicador }\end{array}$ & $\begin{array}{l}\text { Populacã̃o } \\
\text { beneficiada }\end{array}$ & PDC: sigla & $\begin{array}{l}\text { Tempo de } \\
\text { execução } \\
\text { (meses) }\end{array}$ & Descrição \\
\hline $\begin{array}{c}\text { SERVIÇO } \\
\text { AUTÔNOMO } \\
\text { MUNICIPAL DE } \\
\text { ÁGUA EESGOTO DE } \\
\text { TIETÊ- SAMAE }\end{array}$ & $\begin{array}{l}\text { SANEAMENTO } \\
\text { PÚBLICO }\end{array}$ & Cancelado & $14 / 11 / 2012$ & 0 & 0 & 0 & Município & Não reemb. & Outros (contratos) & 36827 & PDC05 & 6 & $\begin{array}{c}\text { O OBJETIVO DO PRESENTE TRABALHO } \\
\text { é A CONTRATAçãO DE UMA EMPRESA } \\
\text { DE ENGENHARIA PARA ELABORAçãO } \\
\text { DO CADA }\end{array}$ \\
\hline $\begin{array}{c}\text { SERVIÇO } \\
\text { AUTÔNOMO } \\
\text { MUNICIPAL DE } \\
\text { ÁGUA EESGOTO DE } \\
\text { TIETÊ- SAMAE }\end{array}$ & $\begin{array}{l}\text { SANEAMENTO } \\
\text { PÚBLICO }\end{array}$ & Cancelado & 14/11/2012 & $356.030,19$ & $39.558,91$ & $395.589,10$ & Município & Não reemb. & $\begin{array}{l}\text { Abastecimento de } \\
\text { Água (habitantes) }\end{array}$ & 36827 & PDC05 & 6 & $\begin{array}{l}\text { O OBJETIVO DESSE TRABALHOÉ } \\
\text { IMPLATAR ATIVIDADES QUE VISAM O } \\
\text { CONTROLE E REDUÇÃO DAS PERDAS } \\
\text { DEÁGUA NO }\end{array}$ \\
\hline $\begin{array}{l}\text { INSTITUTO PHYSIS - } \\
\text { CULTURA E } \\
\text { AMBIENTE }\end{array}$ & $\begin{array}{c}\text { ATIVIDADES DE } \\
\text { ASSOCIAç̃ES DE } \\
\text { DEFESA DE } \\
\text { DIRETTOS SOCIAIS }\end{array}$ & Cancelado & 14/11/2012 & 0 & 0 & 0 & Sociedade Civil & Não reemb. & $\begin{array}{l}\text { Educação } \\
\text { Ambiental } \\
\text { (contratos) }\end{array}$ & 120 & PDC01 & 12 & $\begin{array}{l}\text { DESENVOLVER PROGRAMADE } \\
\text { EDUCAçãO AMBIENTAL }\end{array}$ \\
\hline $\begin{array}{c}\text { SERVIÇO } \\
\text { AUTÔNOMO DE } \\
\text { ÁGUA EESGOTO DE } \\
\text { VOTORANTIM - } \\
\text { SAAE }\end{array}$ & $\begin{array}{l}\text { PREFEITURA } \\
\text { MUNICIPAL }\end{array}$ & Cancelado & 29/05/2012 & $388.765,45$ & $20.461,34$ & $409.226,79$ & Município & Não reemb. & $\begin{array}{l}\text { Abastecimento de } \\
\text { Água (habitantes) }\end{array}$ & 59600 & PDC05 & 7 & REDUção DE PERDAS DE áGUA \\
\hline $\begin{array}{l}\text { ASSOCIAção DOS } \\
\text { GESTORES PELA } \\
\text { UNIDADE } \\
\text { AMBIENTAL- } \\
\text { A.G.U.A. }\end{array}$ & $\begin{array}{l}\text { PROJETOS NA áREA } \\
\text { AMBIENTAL }\end{array}$ & Cancelado & $14 / 11 / 2012$ & 0 & 0 & 0 & Sociedade Civil & Não reemb. & $\begin{array}{l}\text { Recomposiç̃̃o de } \\
\text { Mata Ciliar } \\
\text { (hectares) }\end{array}$ & 1000000 & PDC09 & 24 & $\begin{array}{l}\text { OBJETIVO RESTAURAR áREAS } \\
\text { DEGRADADAS DO PARQUEDA } \\
\text { BIODIVERSIDADE E FORMAR UM } \\
\text { POMAR DE SEMENTES COM AL }\end{array}$ \\
\hline $\begin{array}{c}\text { SERVIÇO } \\
\text { AUTÔNOMO DE } \\
\text { ÁGUA EESGOTO DE } \\
\text { CERQUILHO }\end{array}$ & $\begin{array}{l}\text { SERVICCO DE } \\
\text { SANEAMENTO } \\
\text { BÁSICO }\end{array}$ & Concluído & 13/07/2015 & $143.600,82$ & $34.530,13$ & $178.130,95$ & Municííio & Não reemb. & $\begin{array}{l}\text { Estudos/Projetos } \\
\text { (contratos) }\end{array}$ & 39649 & $\mathrm{PDC} 03$ & 6 & $\begin{array}{l}\text { O OBJETIVO PRINCIPAL DO PRESENTE } \\
\text { TRABALHO CONSISTENA } \\
\text { ELABORAçãO DE PROJETO EXECUTIVO } \\
\text { DO NOVO EMISSá }\end{array}$ \\
\hline $\begin{array}{l}\text { PREFEITURA } \\
\text { MUNIIIPAL DE } \\
\text { PEREIRAS }\end{array}$ & $\begin{array}{l}\text { PREFEITURA } \\
\text { MUNICIPAL }\end{array}$ & Cancelado & 14/11/2012 & 0 & 0 & 0 & Município & Não reemb. & $\begin{array}{l}\text { Coleta e } \\
\text { Tratamento de } \\
\text { Esgotos } \\
\text { (habitantes) }\end{array}$ & 7000 & $\mathrm{PDC03}$ & 2 & $\begin{array}{c}\text { TEM POR OBJETIVO SUBSTITUIR UMA } \\
\text { ESTAçãO ELEVATERIA EXISTENTE QUE } \\
\text { ENCONTRA-SE EM PESSIMO ESTADO } \\
\text { DECO }\end{array}$ \\
\hline $\begin{array}{c}\text { ASSOCIAÇÃO } \\
\text { ECOAR FLORESTAL }\end{array}$ & $\begin{array}{l}\text { REALIZAÇÃ̃ DE } \\
\text { PROJETOS } \\
\text { SOCIOAMBIENTAIS }\end{array}$ & Cancelado & 14/11/2012 & 0 & 0 & 0 & Sociedade Civil & Não reemb. & $\begin{array}{l}\text { Educação } \\
\text { Ambiental } \\
\text { (contratos) }\end{array}$ & 600 & PDC01 & 10 & $\begin{array}{l}\text { 1. CONTRIBUIR COM A FORMAçãO } \\
\text { PESSOALE PROFISSIONAL DOS } \\
\text { EDUCADORES PARA UMA MUDANçA } \\
\text { DECULTURA EM PR }\end{array}$ \\
\hline $\begin{array}{l}\text { PREFEITURA } \\
\text { MUNIIIPALDE } \\
\text { BOTUCATU } \\
\text { PREFEITURA }\end{array}$ & $\begin{array}{l}\text { PREFEITURA } \\
\text { MUNICIPAL }\end{array}$ & Cancelado & $14 / 11 / 2012$ & 0 & 0 & 0 & Município & Não reemb. & $\begin{array}{l}\text { Educação } \\
\text { Ambiental } \\
\text { (contratos) }\end{array}$ & 127328 & PDC01 & 12 & $\begin{array}{l}\text { OBJETIVO: CONSTRUÇão DE CENTRO } \\
\text { DE EDUCAÇãO AMBIENTAL EM } \\
\text { PARQUE MUNICIPAL }\end{array}$ \\
\hline $\begin{array}{l}\text { MUNICIPALDE } \\
\text { LARANJAL } \\
\text { PAULISTA }\end{array}$ & $\begin{array}{l}\text { PREFEITURA } \\
\text { MUNICIPAL }\end{array}$ & Concluído & 05/06/2015 & $349.371,20$ & $6.847,90$ & $356.219,10$ & Município & Não reemb. & $\begin{array}{l}\text { Trat. e Disposicicão } \\
\text { de Lixo - Obras } \\
\text { (habitantes) }\end{array}$ & 25119 & PDC03 & 12 & $\begin{array}{c}\text { DIMINUIR A INCIDêNCIA DE DEPŚSITO } \\
\text { DE PRODUTOS RECíCLA VEIS NO } \\
\text { ATERRO SANITARIO EDEMAIS áREAS } \\
\text { REDUZIN }\end{array}$ \\
\hline $\begin{array}{l}\text { PREFEITURA } \\
\text { MUNICIPAL DE } \\
\text { PIEDADE }\end{array}$ & $\begin{array}{l}\text { PREFEITURA } \\
\text { MUNICIPAL }\end{array}$ & Concluído & 06/01/2016 & $98.108,00$ & $15.899,00$ & $114.007,00$ & Município & Não reemb. & $\begin{array}{l}\text { Estudos/Projetos } \\
\text { (contratos) }\end{array}$ & 51416 & PDC09 & 12 & $\begin{array}{c}\text { DEFINIR AS áREAS PRIORITáRIAS } \\
\text { PARA CONSERVAçãO E PRESERVAção } \\
\text { DO SERVIçO AMBENTEAĹGUA NAS } \\
\text { SUB BACIA áG }\end{array}$ \\
\hline $\begin{array}{c}\text { SERVICO } \\
\text { AUTONOMO DE } \\
\text { AGUA, ESGOTOE } \\
\text { MEIO AMBIENTE- } \\
\text { SAAE AMBIENTAL }\end{array}$ & $\begin{array}{l}\text { SETOR DE } \\
\text { SANEAMENTO } \\
\text { BáSICO }\end{array}$ & Cancelado & 28/12/2012 & $118.456,00$ & $29.614,00$ & $148.070,00$ & Município & Não reemb. & $\begin{array}{l}\text { Planej. e Gerenc. } \\
\text { dos Recs. Hídricos } \\
\text { (contratos) }\end{array}$ & 105569 & PDC01 & 6 & $\begin{array}{l}\text { O SERVIÇO AUTôNOMO DE ÁGUA E } \\
\text { ESGOTO (SAAE) DE SALTO SERÁ O } \\
\text { RESPONŚVEL TOMADOR DOS } \\
\text { RECURSOS DO FEHID }\end{array}$ \\
\hline
\end{tabular}




\begin{tabular}{|c|c|c|c|c|c|c|c|c|c|c|c|c|c|}
\hline Nome do interessado & $\begin{array}{l}\text { Atividade principal do } \\
\text { interessado }\end{array}$ & $\begin{array}{c}\text { Situação do } \\
\text { emprendimento }\end{array}$ & $\begin{array}{c}\text { Data de } \\
\text { conclusão }\end{array}$ & Valor aprovado & $\begin{array}{c}\text { Valor de } \\
\text { contrapartida }\end{array}$ & Valor total & $\begin{array}{l}\text { Segmento do } \\
\text { interessado }\end{array}$ & Modalidade & $\begin{array}{l}\text { Benefício: } \\
\text { indicador }\end{array}$ & $\begin{array}{l}\text { Populacã̃o } \\
\text { beneficiada }\end{array}$ & PDC: sigla & $\begin{array}{l}\text { Tempo de } \\
\text { execução } \\
\text { (meses) }\end{array}$ & Descrição \\
\hline $\begin{array}{l}\text { SERVIÇO } \\
\text { AUTÔNOMO DE } \\
\text { ÁGUA EESGOTO DE } \\
\text { CERQUILHO }\end{array}$ & $\begin{array}{l}\text { SERVIÇO DE } \\
\text { SANEAMENTO } \\
\text { BÁSICO }\end{array}$ & Concluído & $13 / 10 / 2014$ & $392.436,50$ & $108.600,00$ & $501.036,50$ & Município & Não reemb. & $\begin{array}{l}\text { Abastecimento de } \\
\text { Ágaa (habitantes) }\end{array}$ & 39649 & PDC05 & 12 & $\begin{array}{c}\text { O OBJETIVO DO PRESENTE TRABALHO } \\
\text { é IMPLANTAR ATIVIDADES QUE } \\
\text { VISAM O CONTROLE EREDUção DAS } \\
\text { PERDAS DE }\end{array}$ \\
\hline $\begin{array}{l}\text { PREFEITURA DO } \\
\text { MUNICIPIO DE TIETÊ }\end{array}$ & $\begin{array}{l}\text { ADMINISTRAÇ̃̃o } \\
\text { MUNICIPAL }\end{array}$ & Cancelado & 19/11/2012 & $104.663,92$ & $26.165,98$ & $130.829,90$ & Município & Não reemb. & $\begin{array}{c}\text { Estudos//Projetos } \\
\text { (contratos) }\end{array}$ & 36827 & PDC03 & 6 & $\begin{array}{l}\text { O OBJETIVO PRINCIPAL DO PRESENTE } \\
\text { TRABALHO CONSISTE NA } \\
\text { ELABORAçãO DE PROJETO EXECUTIVO } \\
\text { DO EMISŚRIO D }\end{array}$ \\
\hline $\begin{array}{l}\text { IPESA - INSTITUTO } \\
\text { DE PROIETOS E } \\
\text { PESQUISAS } \\
\text { AGÊNCIA }\end{array}$ & MEIO AMBIENTE & Emexecução & & $181.993,00$ & $19.582,00$ & $201.575,00$ & Sociedade Civil & Não reemb. & $\begin{array}{l}\text { Estudos/Projetos } \\
\text { (contratos) }\end{array}$ & 696000 & PDC09 & 12 & $\begin{array}{l}\text { PRODUZIR MATERIAL CARTOGRáFICO } \\
\text { EM ESCALA DE DETALHE (1:10.000) } \\
\text { PARA SUBSIDIAR A RECUPERAçãO DE }\end{array}$ \\
\hline $\begin{array}{l}\text { REGULADORA DE } \\
\text { SERVIÇOS } \\
\text { DELEGADOS DO } \\
\text { MUNICÍPIO DA } \\
\text { ESTÂNCIA } \\
\text { TURÍSTICA DE ITU - } \\
\text { AR-ITU }\end{array}$ & $\begin{array}{l}\text { SANEAMENTO } \\
\text { BÁSICO }\end{array}$ & Cancelado & 28/12/2012 & $185.881,36$ & $93.765,64$ & $279.647,00$ & Município & Não reemb. & Outros (contratos) & 80000 & PDC01 & 12 & $\begin{array}{l}\text { : O OBJETIVO ESPECiFICO (êNFASE) é O } \\
\text { DE EFETUAR ESTUDO, à LUZ DAS } \\
\text { INTERFERêNCIAS ANTRóPICAS, DE } \\
\text { CARA }\end{array}$ \\
\hline $\begin{array}{l}\text { PUC- FUNDAçãO SãO } \\
\text { PAULO - FUNDASP, } \\
\text { MANTENEDORA DA } \\
\text { PUC/SP }\end{array}$ & $\begin{array}{l}\text { ENSINO PESQUISA E } \\
\text { EXTENSão }\end{array}$ & Cancelado & $24 / 04 / 2015$ & $112.940,28$ & $15.222,45$ & $128.162,73$ & Sociedade Civil & Não reemb. & $\begin{array}{l}\text { Estudos/Projetos } \\
\text { (contratos) }\end{array}$ & 1000 & PDC09 & 12 & $\begin{array}{l}\text { PRODUÇãO DE MAPAS ( A PARTIR DE } \\
\text { IMAGENS DE SATÉLITE) E } \\
\text { PROTOCOLOS COM DIAGNóSTICOS DO } \\
\text { USO DA TERRA, }\end{array}$ \\
\hline $\begin{array}{l}\text { FUNDAĈ̃̃O PARA A } \\
\text { CONSERVAÇÃO E A }\end{array}$ & $\begin{array}{c}\text { CONSERVACC̃̃O, } \\
\text { PRODUÇÃO E }\end{array}$ & Cancelado & 28/12/2012 & $292.850,00$ & $32.736,00$ & $325.586,00$ & Estado & Não reemb. & $\begin{array}{l}\text { Planej. e Gerenc. } \\
\text { dos Recs. Hídricos }\end{array}$ & 39628 & PDC01 & 12 & $\begin{array}{l}\text { OBJETIVO: O OBJETIVO DO PRESENTE } \\
\text { PROJETO é ELABORAR O PLANO DE }\end{array}$ \\
\hline $\begin{array}{l}\text { IPESA - INSTITUTO } \\
\text { DE PROJETOS E } \\
\text { PESQUISAS } \\
\text { SOCIOAMBIENTAIS }\end{array}$ & MEIO AMBIENTE & Cancelado & 19/11/2012 & 0 & 0 & 0 & Sociedade Civil & Não reemb. & $\begin{array}{l}\text { Trat. e Disposicicão } \\
\text { de Lixo - Obras } \\
\text { (habitantes) }\end{array}$ & 615199 & PDC03 & 12 & $\begin{array}{l}\text { REALIZAR DIAGNóSTICO DOS } \\
\text { RESIDUOS SóLIDOS URBANOS, DE } \\
\text { RESPONSABILIDADE DO PODER } \\
\text { PúBLICO MUNICIPAL, N }\end{array}$ \\
\hline $\begin{array}{l}\text { CETESB - } \\
\text { COMPANHIA }\end{array}$ & $\begin{array}{l}\text { AG-ENCIA } \\
\text { AMBIENTALDO }\end{array}$ & Cancelado & 19/11/2012 & 0 & 0 & 0 & Estado & Não reemb. & Outros (contratos) & 600000 & PDC09 & 12 & $\begin{array}{l}\text { PROPOR E APLICAR METODOLOGIA } \\
\text { PARA AUTOMATIZAçãO DA TéCNICA } \\
\text { JUSTIFICATIVA: NA PERSPECTIVA DO }\end{array}$ \\
\hline $\begin{array}{l}\text { PREFEITURA } \\
\text { MUNICIPALDE } \\
\text { VOTORANTIM }\end{array}$ & $\begin{array}{l}\text { PREFEITURA } \\
\text { MUNICIPAL }\end{array}$ & Cancelado & 19/11/2012 & $264.367,71$ & $13.914,09$ & $278.281,80$ & Município & Não reemb. & Outros (contratos) & 180000 & PDC01 & 8 & $\begin{array}{l}\text { DESEJADO DESENVOLVIMENTO GERAL } \\
\text { DO MUNICIPIO, A CONTINUIDADE DOS } \\
\text { VET }\end{array}$ \\
\hline $\begin{array}{l}\text { PREFEITURA DO } \\
\text { MUNICIPIO DE TIETÊ }\end{array}$ & $\begin{array}{l}\text { ADMINISTRAÇão } \\
\text { MUNICIPAL }\end{array}$ & Cancelado & 19/11/2012 & $130.334,32$ & $14.481,59$ & $144.815,91$ & Município & Não reemb. & $\begin{array}{l}\text { Estudos/Projetos } \\
\text { (contratos) }\end{array}$ & 36827 & PDC08 & 6 & $\begin{array}{l}\text { ESTE TRABALHO TEM POR OBJETIVO } \\
\text { A ELABORAçãO DE UM PLANO } \\
\text { DIRETOR DE MACRODRENAGEM } \\
\text { URBANA, VISANDO EXE }\end{array}$ \\
\hline $\begin{array}{l}\text { PREFEITURA } \\
\text { MUNICIPALDE } \\
\text { TATUÍ }\end{array}$ & $\begin{array}{l}\text { PREFEITURA } \\
\text { MUNICIPAL }\end{array}$ & Cancelado & 19/11/2012 & $178.233,97$ & $3.637,43$ & $181.871,40$ & Município & Não reemb. & $\begin{array}{l}\text { Estudos/Projetos } \\
\text { (contratos) }\end{array}$ & 109413 & PDC08 & 6 & $\begin{array}{l}\text { ELABORAção DO PLANO DIRETOR DE } \\
\text { DRENAGEM URBANA PARA } \\
\text { CONTROLE DE EROSãO DO SOLO E } \\
\text { INUNDAççES EM áREAS }\end{array}$ \\
\hline $\begin{array}{l}\text { PREFEITURA } \\
\text { MUNICIPAL DE } \\
\text { VARGEM GRANDE } \\
\text { PAULISTA }\end{array}$ & $\begin{array}{l}\text { PREFEITURA } \\
\text { MUNICIPAL }\end{array}$ & Cancelado & $28 / 12 / 2012$ & $71.250,00$ & $3.750,00$ & $75.000,00$ & Município & Não reemb. & $\begin{array}{l}\text { Trat. e Disposicião } \\
\text { de Lixo - Obras } \\
\text { (habitantes) }\end{array}$ & 45000 & $\mathrm{PDC} 03$ & 3 & $\begin{array}{l}\text { OBJETIVO: DETERMINAR SÉREA } \\
\text { AINDA APRESENTA RISCO DE } \\
\text { CONTAMINAçãO AMBIENTALE } \\
\text { AVALIAR A EFICáCIA DA } \\
\text { RFCIPERAc̃̃O }\end{array}$ \\
\hline $\begin{array}{l}\text { PREFEITURA } \\
\text { MUNICIPALDE } \\
\text { BOITUVA }\end{array}$ & $\begin{array}{l}\text { ORGăO PUBLICO } \\
\text { (PREFEITURA) }\end{array}$ & Cancelado & 03/06/2013 & $365.619,55$ & $20.852,15$ & $386.471,70$ & Município & Não reemb. & $\begin{array}{l}\text { Recomposiç̃ã de } \\
\text { Mata Ciliar } \\
\text { (hectares) }\end{array}$ & 100 & PDC05 & 24 & $\begin{array}{c}\text { RECUPERAção DE AREAS } \\
\text { DEGRADADAS COM } \\
\text { REFLORESTAMENTO, DIMINUINDO O } \\
\text { ESCORIMENTO SUPERFICIAL DE } \\
\text { AGUAS P }\end{array}$ \\
\hline $\begin{array}{l}\text { PREFEITURA } \\
\text { MUNIIIPALDE } \\
\text { QUADRA }\end{array}$ & $\begin{array}{l}\text { PREFEITURA } \\
\text { MUNICIPAL }\end{array}$ & Cancelado & 19/11/2012 & $279.300,00$ & $5.700,00$ & $285.000,00$ & Município & Não reemb. & $\begin{array}{l}\text { Coleta e } \\
\text { Tratamento de } \\
\text { Esgotos } \\
\text { (habitantes) }\end{array}$ & 400 & $\mathrm{PDC} 03$ & 6 & $\begin{array}{c}\text { MELHORAR A QUALIDADE DE VIDA } \\
\text { DA POPULAçãO RURAL REFERENTE A } \\
\text { COLETA E TRATAMENTO DE ESGOTO } \\
\text { DOMÉSTICO, }\end{array}$ \\
\hline
\end{tabular}




\begin{tabular}{|c|c|c|c|c|c|c|c|c|c|c|c|c|c|}
\hline Nome do interessado & $\begin{array}{l}\text { Atividade principal do } \\
\text { interessado }\end{array}$ & $\begin{array}{l}\text { Situação do } \\
\text { empreendimento }\end{array}$ & $\begin{array}{l}\text { Data de } \\
\text { conclusão }\end{array}$ & Valor aprovado & $\begin{array}{l}\text { Valor de } \\
\text { contrapartida }\end{array}$ & Valor total & $\begin{array}{l}\text { Segmento do } \\
\text { interessado }\end{array}$ & Modalidade & $\begin{array}{l}\text { Benefício: } \\
\text { indicador }\end{array}$ & $\begin{array}{l}\text { População } \\
\text { beneficiada }\end{array}$ & PDC: sigla & $\begin{array}{c}\text { Tempo de } \\
\text { execução } \\
\text { (meses) }\end{array}$ & Descrição \\
\hline $\begin{array}{l}\text { PREFEITURA } \\
\text { MUNICIPAL DE } \\
\text { PEREIRAS }\end{array}$ & $\begin{array}{l}\text { PREFEITURA } \\
\text { MUNICIPAL }\end{array}$ & Cancelado & 14/06/2013 & $144.546,66$ & $3.080,00$ & $147.626,66$ & Município & Não reemb. & $\begin{array}{l}\text { Trat. e Disposição } \\
\text { de Lixo - Obras } \\
\text { (habitantes) }\end{array}$ & 7468 & PDC03 & 3 & $\begin{array}{c}\text { RESOLVER O PROBLEMA DO } \\
\text { TRANSPORTE DE RESIDUO SóLIDO } \\
\text { DOMÉSTICO }\end{array}$ \\
\hline $\begin{array}{l}\text { PREFEITURA } \\
\text { MUNICIPALDE } \\
\text { IPERÓ }\end{array}$ & $\begin{array}{l}\text { PREFEITURA } \\
\text { MUNICIPAL }\end{array}$ & Em execução & - & $195.046,59$ & $64.719,08$ & $259.765,67$ & Município & Não reemb. & $\begin{array}{l}\text { Coleta e } \\
\text { Tratamento de } \\
\text { Esgotos } \\
\text { (habitantes) }\end{array}$ & 6000 & PDC03 & 4 & $\begin{array}{l}\text { O EMPREENDIMENTO VISA } \\
\text { BENEFICIAR DIRETAMENTE O BAIRRO } \\
\text { CAMPOS VILETA }\end{array}$ \\
\hline $\begin{array}{l}\text { PREFEITURA } \\
\text { MUNICIPAL DE } \\
\text { IPERÓ }\end{array}$ & $\begin{array}{l}\text { PREFEITURA } \\
\text { MUNICIPAL }\end{array}$ & Em execução & - & $176.927,53$ & $68.768,90$ & $245.696,43$ & Município & Não reemb. & $\begin{array}{l}\text { Coleta e } \\
\text { Tratamento de } \\
\text { Esgotos } \\
\text { (habitantes) }\end{array}$ & 2000 & $\mathrm{PDC}_{3}$ & 4 & $\begin{array}{l}\text { O EMPREENDIMENTO VISA } \\
\text { BENEFICIAR DIRETAMENTEA } \\
\text { COMUNIDADE }\end{array}$ \\
\hline $\begin{array}{l}\text { SERVIÇO } \\
\text { AUTÔNOMO DE } \\
\text { ÁGUA EESGOTO DE } \\
\text { CERQUILHO }\end{array}$ & $\begin{array}{l}\text { SERVIÇO DE } \\
\text { SANEAMENTO } \\
\text { BÁSICO }\end{array}$ & Concluído & $24 / 08 / 2015$ & $118.068,00$ & $29.130,40$ & $147.198,40$ & Município & Não reemb. & Outros (contratos) & 39649 & PDC05 & 6 & $\begin{array}{l}\text { O OBJETIVO DO PRESENTE TRABALHO } \\
\text { é IMPLANTAR A MODELAGEM DE } \\
\text { SIMULAção COM O MODELO } \\
\text { MATEMáTICO PARA AD }\end{array}$ \\
\hline $\begin{array}{c}\text { SERVIÇO } \\
\text { AUTÔNOMO } \\
\text { MUNICIPAL DE } \\
\text { ÁGUA EESGOTO DE } \\
\text { TIETÊ-SAMAE }\end{array}$ & $\begin{array}{l}\text { SANEAMENTO } \\
\text { PÚBLICO }\end{array}$ & Concluído & 09/06/2017 & $396.867,89$ & $91.632,00$ & $488.499,89$ & Município & Não reemb. & Outros (contratos) & 36827 & PDC05 & 6 & $\begin{array}{c}\text { OBJETIVO DESSE TRABALHOÉ } \\
\text { IMPLATAR ATIVIDADES QUE VISAM O } \\
\text { CONTROLEE REDUÇÃO DAS PERDAS } \\
\text { DE ÁGUA NO S }\end{array}$ \\
\hline $\begin{array}{c}\text { CONSÓRCIO DE } \\
\text { ESTUDOS, } \\
\text { RECUPERAÇÃ̃O E } \\
\text { DESENVOLVIMENTO } \\
\text { DA BACIA DOS RIOS } \\
\text { SOROCABA EMÉDIO } \\
\text { TIETEE - CERISO }\end{array}$ & $\begin{array}{l}\text { CONSÓRCIO } \\
\text { INTERMUNICIPAL }\end{array}$ & Cancelado & 10/04/2013 & 0 & 0 & 0 & Sociedade Civil & Não reemb. & $\begin{array}{l}\text { Estudos/Projetos } \\
\text { (contratos) }\end{array}$ & 1800000 & PDC01 & 12 & $\begin{array}{l}\text { O PLANO DE COMUNICAção VISA } \\
\text { ESTABELECER ALGUMAS ATIVIDADES } \\
\text { PARA APERFEIçOAR A COMUNICA̧̧ãO } \\
\text { EDIVULGAç }\end{array}$ \\
\hline $\begin{array}{c}\text { SERVIÇO } \\
\text { AUTÔNOMO DE } \\
\text { ÁGUA EESGOTO DE } \\
\text { PORTO FELIZ (SAAE) }\end{array}$ & $\begin{array}{l}\text { PREFEITURA } \\
\text { MUNICIPAL }\end{array}$ & Concluído & $15 / 12 / 2014$ & $400.000,00$ & $83.140,80$ & $483.140,80$ & Município & Não reemb. & $\begin{array}{l}\text { Abastecimento de } \\
\text { Água (habitantes) }\end{array}$ & 16000 & $\mathrm{PDC} 05$ & 4 & $\begin{array}{c}\text { O OBJETIVO DA Ação PROPOSTA é DE } \\
\text { OBTER MAIOR CONTROLEE } \\
\text { CONFIABILIDADE QUANTO àS PERDAS } \\
\text { APARENTES (N }\end{array}$ \\
\hline $\begin{array}{l}\text { CONSÓRCIO DE } \\
\text { ESTUDOS, } \\
\text { RECUPERAÇÃOO E } \\
\text { DESENVOLVIMENTO }\end{array}$ & $\begin{array}{c}\text { CONSÓRCIO } \\
\text { INTERMUNICIPAL }\end{array}$ & Cancelado & 10/04/2013 & 0 & 0 & 0 & Sociedade Civil & Não reemb. & $\begin{array}{l}\text { Abastecimento de } \\
\text { Água (habitantes) }\end{array}$ & 234154 & $\mathrm{PDC} 05$ & 6 & $\begin{array}{l}\text { OS SISTEMAS DE ABASTECIMENTO DE } \\
\text { áGUA DE CERQUILHO, PORTO FELIZ, } \\
\text { TIêTEE VOTORANTIM Já POSSUEM } \\
\text { ALGUMA }\end{array}$ \\
\hline $\begin{array}{l}\text { PREFEITURA } \\
\text { MUNICIPAL DE } \\
\text { JUMIRIM }\end{array}$ & $\begin{array}{l}\text { PREFEITURA } \\
\text { MUNICIPAL }\end{array}$ & Concluído & 02/09/2016 & $80.838,00$ & $8.800,00$ & $89.638,00$ & Município & Não reemb. & $\begin{array}{l}\text { Estudos/Projetos } \\
\quad \text { (contratos) }\end{array}$ & 2801 & PDC05 & 4 & $\begin{array}{l}\text { ESTE TRABALHO TEM POR OBJETIVO } \\
\text { A ELABORAção DE UM PLANO } \\
\text { DIRETOR DECOMBATE AS PERDAS DE } \\
\text { ÁGUA, COM A }\end{array}$ \\
\hline $\begin{array}{l}\text { PREFEITURA } \\
\text { MUNICIPAL DE } \\
\text { IPERÓ }\end{array}$ & $\begin{array}{l}\text { PREFEITURA } \\
\text { MUNICIPAL }\end{array}$ & Cancelado & 10/04/2013 & 0 & 0 & 0 & Município & Não reemb. & $\begin{array}{l}\text { Coleta e } \\
\text { Tratamento de } \\
\text { Esgotos } \\
\text { (habitantes) }\end{array}$ & 5884 & $\mathrm{PDCO}_{3}$ & 4 & $\begin{array}{c}\text { A IMPLANTAÇÃO DO } \\
\text { EMPREENDIMENTO TEM COMO } \\
\text { OBJETIVO MELORAR A SAÚDE } \\
\text { PÚBLICA DA COMUNIDADE EATUAR } \\
\text { PAR }\end{array}$ \\
\hline $\begin{array}{c}\text { ASSOCIACCÃO } \\
\text { ECOAR FLORESTAL }\end{array}$ & $\begin{array}{l}\text { REALIZAÇÃO DE } \\
\text { PROJTOS } \\
\text { SOCIOAMBIENTAIS }\end{array}$ & Cancelado & 10/04/2013 & 0 & 0 & 0 & Sociedade Civil & Não reemb. & $\begin{array}{l}\text { Educação } \\
\text { Ambiental } \\
\text { (contratos) }\end{array}$ & 1200000 & PDC01 & 14 & $\begin{array}{c}\text { FOMENTAR, SENSIBILIZAR E } \\
\text { MOBILIZAR DIFERENTES ATORES DA } \\
\text { BACIA DO SMT, PARA A FORMAçãO } \\
\text { DE UM COLETIVO }\end{array}$ \\
\hline
\end{tabular}




\begin{tabular}{|c|c|c|c|c|c|c|c|c|c|c|c|c|c|}
\hline Nome do interessado & $\begin{array}{l}\text { Atividade principal do } \\
\text { interessado }\end{array}$ & $\begin{array}{l}\text { Situação do } \\
\text { empreendimento }\end{array}$ & $\begin{array}{l}\text { Data de } \\
\text { conclusão }\end{array}$ & Valor aprovado & $\begin{array}{c}\text { Valor de } \\
\text { contrapartida }\end{array}$ & Valor total & $\begin{array}{l}\text { Segmento do } \\
\text { interessado }\end{array}$ & Modalidade & $\begin{array}{l}\text { Benefício: } \\
\text { indicador }\end{array}$ & $\begin{array}{c}\text { População } \\
\text { beneficiada }\end{array}$ & PDC: sigla & $\begin{array}{l}\text { Tempo de } \\
\text { execução } \\
\text { (meses) }\end{array}$ & Descrição \\
\hline $\begin{array}{l}\text { PREFEITURA } \\
\text { MUNICIPALDE } \\
\text { TATUÍ }\end{array}$ & $\begin{array}{l}\text { PREFEITURA } \\
\text { MUNICIPAL }\end{array}$ & Cancelado & 10/04/2013 & 0 & 0 & 0 & Município & Não reemb. & $\begin{array}{l}\text { Educação } \\
\text { Ambiental } \\
\text { (contratos) }\end{array}$ & 110000 & PDC01 & 24 & $\begin{array}{l}\text { ESTE PROJETO PREVÊ A IMPLANTAção } \\
\text { DE UMA GESTão SUSTENTáVELL DOS } \\
\text { RESiDUOS SóLIDOS ATRA VéS DE } \\
\text { AçõES DE }\end{array}$ \\
\hline $\begin{array}{c}\text { PREFEITURA } \\
\text { MUNICIPALDE } \\
\text { CAPELA DO ALTO }\end{array}$ & $\begin{array}{l}\text { PREFEITURA } \\
\text { MUNICIPAL }\end{array}$ & Cancelado & 10/04/2013 & 0 & 0 & 0 & Município & Não reemb. & $\begin{array}{l}\text { Galerias de Águas } \\
\text { Pluviais (metros } \\
\text { lineares) }\end{array}$ & 2000 & $\mathrm{PDC} 08$ & 6 & $\begin{array}{c}\text { O OBJETIVO ÉFAZER UM CORREDOR } \\
\text { SUBTERRÂNEO, FORMADO A PARTIR } \\
\text { DAS GALERIAS, DIRECIONE A ÁGUA } \\
\text { DA CRUVA }\end{array}$ \\
\hline ASSOCIAÇÃO DOS & & & & & & & & & & & & & \\
\hline $\begin{array}{l}\text { PROPRIETARIOS E } \\
\text { AMIGOS DAS } \\
\text { CHÁCARAS } \\
\text { ARAPONGAS E } \\
\text { ÁGUAS } \\
\text { CRISTALINAS }\end{array}$ & $\begin{array}{c}\text { ASSOCIAçãO DE } \\
\text { DEFESA DE } \\
\text { DIREITOS SOCIAIS. }\end{array}$ & Cancelado & 10/04/2013 & 0 & 0 & 0 & Sociedade Civil & Não reemb. & Outros (contratos) & 800 & PDC01 & 12 & $\begin{array}{l}\text { PROPOR MEDIDAS E Aç̃̃ES QUE } \\
\text { ESTIMULEM A MUDANçA DE } \\
\text { COMPORTAMENTO E HáBITOS NA } \\
\text { BUSCA DE MELHORES CONDI }\end{array}$ \\
\hline $\begin{array}{c}\text { AGÊNCIA } \\
\text { REGULADORA DE }\end{array}$ & & & & & & & & & & & & & \\
\hline $\begin{array}{l}\text { SERVIÇOS } \\
\text { DELEGADOS DO } \\
\text { MUNIĆ́PIO DA } \\
\text { ESTÂNCIA } \\
\text { TURÍSTICA DE ITU - } \\
\text { AR-ITU }\end{array}$ & $\begin{array}{l}\text { SANEAMENTO } \\
\text { BÁSICO }\end{array}$ & Cancelado & 10/04/2013 & 0 & 0 & 0 & Município & Não reemb. & $\begin{array}{l}\text { Abastecimento de } \\
\text { Agua (habitantes) }\end{array}$ & 34700 & PDC09 & 12 & $\begin{array}{l}\text { RECUPERAÇÃO DE } 12 \text { HA DA BACIA } \\
\text { DO CÓRREGO ITAINZINHO COM } \\
\text { PLANTIO DIRETO DE 20.000 MUDAS EO } \\
\text { DESENVOLV }\end{array}$ \\
\hline $\begin{array}{l}\text { PREFEITURA } \\
\text { MUNICIPALDE } \\
\text { IPERÓ }\end{array}$ & $\begin{array}{l}\text { PREFEITURA } \\
\text { MUNICIPAL }\end{array}$ & Emexecução & & $211.350,99$ & $124.600,62$ & $335.951,61$ & Município & Não reemb. & $\begin{array}{c}\text { Coleta e } \\
\text { Tratamento de } \\
\text { Esgotos } \\
\text { (habitantes) }\end{array}$ & 425 & $\mathrm{PDC} 03$ & 5 & $\begin{array}{c}\text { TORNAR ADEQUADO O SANEAMENTO } \\
\text { BÁSICO NA BACIA }\end{array}$ \\
\hline $\begin{array}{l}\text { PREFEITURA } \\
\text { MUNICIPAL DE } \\
\text { CONCHAS }\end{array}$ & $\begin{array}{l}\text { PREFEITURA } \\
\text { MUNICIPAL }\end{array}$ & Emexecução & - & $151.461,74$ & $1.941,57$ & $153.403,31$ & Município & Não reemb. & $\begin{array}{l}\text { Estudos/Projetos } \\
\quad \text { (contratos) }\end{array}$ & 16423 & PDC08 & 6 & $\begin{array}{c}\text { ELABORAçãO DO PLANO DIRETOR DE } \\
\text { DRENAGEM URBANA PARA } \\
\text { CONTROLE DE EROSãO DO SOLO E } \\
\text { INUNDAçõES EM áREAS }\end{array}$ \\
\hline $\begin{array}{l}\text { IPESA - INSTITUTO } \\
\text { DE PROJETOS E } \\
\text { PESQUISAS } \\
\text { SOCIOAMBIENTAIS }\end{array}$ & MEIO AMBIENTE & Cancelado & 10/04/2013 & 0 & 0 & 0 & Sociedade Civil & Não reemb. & $\begin{array}{l}\text { Estudos/Projetos } \\
\quad \text { (contratos) }\end{array}$ & 15000 & PDC01 & 12 & $\begin{array}{l}\text { 1- ELABORAR UM BANCO DE DADOS } \\
\text { QUE POSSA SUBSIDIAR O COMITê DE } \\
\text { BACIAS HIDROGRáFICAS - SOROCABA }\end{array}$ \\
\hline $\begin{array}{l}\text { SOCIOAMBIENTAIS } \\
\text { IPESA - INSTITUTO } \\
\text { DE PROJETOS E } \\
\text { PESQUISAS } \\
\text { SOCIOAMBIENTAIS }\end{array}$ & MEIO AMBIENTE & Cancelado & 10/04/2013 & 0 & 0 & 0 & Sociedade Civil & Não reemb. & $\begin{array}{l}\text { Recomposição de } \\
\text { Mata Ciliar } \\
\text { (hectares) }\end{array}$ & 15000 & PDC09 & 18 & $\begin{array}{c}\text { MéDIO } \\
\text { REALIZAR A RECOMPOSIção } \\
\text { FLORESTAL DE 08 (OITO) áREAS NA } \\
\text { BACIA DO RIBEIRãO SOROCABUçú } \\
\text { COM ESPéCIES NA }\end{array}$ \\
\hline $\begin{array}{c}\text { SERVICO } \\
\text { AUTONOMO DE } \\
\text { AGUA, ESGOTO E } \\
\text { MEIO AMBIENTE- } \\
\text { SAAE AMBIENTAL }\end{array}$ & $\begin{array}{l}\text { SETOR DE } \\
\text { SANEAMENTO } \\
\text { BáSICO }\end{array}$ & Cancelado & 10/04/2013 & 0 & 0 & 0 & Município & Não reemb. & $\begin{array}{l}\text { Estudos/Projetos } \\
\text { (contratos) }\end{array}$ & 105569 & PDC01 & 6 & $\begin{array}{l}\text { O OBJETIVO GERAL DO PRESENTE } \\
\text { TRABALHO É ABTENçãO DE UM } \\
\text { BANCO DE DADOS COM } \\
\text { LEVANTAMENTO TOPOGRAFICO }\end{array}$ \\
\hline $\begin{array}{c}\text { PREFEITURA } \\
\text { MUNICIPAL DE } \\
\text { CESÁRIO LANGE }\end{array}$ & $\begin{array}{l}\text { PÚBLICA/EXECUTIV } \\
\text { A }\end{array}$ & Emexecução & - & $97.057,24$ & $1.883,25$ & $98.940,49$ & Município & Não reemb. & $\begin{array}{l}\text { Estudos/Projetos } \\
\quad \text { (contratos) }\end{array}$ & 15809 & $\mathrm{PDC08}$ & 6 & $\begin{array}{l}\text { ELABORAç̃̃o DO PLANO DIRETOR DE } \\
\text { DRENAGEM URBANA PARA } \\
\text { CONTROLE DE EROSãO DO SOLO E } \\
\text { INUNDAçõES EM áREAS }\end{array}$ \\
\hline $\begin{array}{l}\text { PREFEITURA } \\
\text { MUNICIPALDE } \\
\text { CERQUILHO }\end{array}$ & $\begin{array}{l}\text { PREFEITURA } \\
\text { MUNICIPAL }\end{array}$ & Concluído & 29/05/2015 & $118.897,84$ & $29.464,69$ & $148.362,53$ & Município & Não reemb. & $\begin{array}{l}\text { Galerias de Águas } \\
\text { Pluviais (metros } \\
\text { lineares) }\end{array}$ & 39617 & PDC08 & 6 & $\begin{array}{l}\text { ESTE TRABALHO TEM POR OBJETIVO } \\
\text { A ELABORAçãO DE UM PLANO } \\
\text { DIRETOR DE MACRODRENAGEM } \\
\text { URBANA, VISANDO EXE }\end{array}$ \\
\hline $\begin{array}{l}\text { PREFEITURA } \\
\text { MUNICIPALDE } \\
\text { CERQUILHO }\end{array}$ & $\begin{array}{l}\text { PREFEITURA } \\
\text { MUNICIPAL }\end{array}$ & Cancelado & 10/04/2013 & 0 & 0 & 0 & Município & Não reemb. & $\begin{array}{l}\text { Estudos/Projetos } \\
\text { (contratos) }\end{array}$ & 39617 & $\mathrm{PDC} 03$ & 6 & $\begin{array}{l}\text { SEGUINDO A LEI FEDEERAL DE } \\
\text { RESIDUOS SOLIDOS DE 2010, O } \\
\text { OBJETIVO DO PRESENTE TRABALHO é } \\
\text { A CONTRATAção }\end{array}$ \\
\hline
\end{tabular}




\begin{tabular}{|c|c|c|c|c|c|c|c|c|c|c|c|c|c|}
\hline Nome do interessado & $\begin{array}{l}\text { Atividade principal do } \\
\text { interessado }\end{array}$ & $\begin{array}{c}\text { Situação do } \\
\text { empreendimento }\end{array}$ & $\begin{array}{l}\text { Data de } \\
\text { conclusão }\end{array}$ & Valor aprovado & $\begin{array}{c}\text { Valor de } \\
\text { contrapartida }\end{array}$ & Valor total & $\begin{array}{l}\text { Segmento do } \\
\text { interessado }\end{array}$ & Modalidade & $\begin{array}{l}\text { Benefício: } \\
\text { indicador }\end{array}$ & $\begin{array}{c}\text { Populacãao } \\
\text { beneficiada }\end{array}$ & PDC: sigla & $\begin{array}{l}\text { Tempo de } \\
\text { execução } \\
\text { (meses) }\end{array}$ & Descrição \\
\hline $\begin{array}{l}\text { SERVIÇO } \\
\text { AUTOONOMO DE } \\
\text { ÁGUA EEGOTO DE } \\
\text { CERQUILHO }\end{array}$ & $\begin{array}{l}\text { SERVIÇO DE } \\
\text { SANEAMENTO } \\
\text { BÁSICO }\end{array}$ & Cancelado & $10 / 04 / 2013$ & 0 & 0 & 0 & Município & Não reemb. & $\begin{array}{l}\text { Planej. e Gerenc. } \\
\text { dos Recs. Hidricos } \\
\text { (contratos) }\end{array}$ & 39617 & $\mathrm{PDC} 03$ & 6 & $\begin{array}{l}\text { ESTE TRABALHO TEM POR OBJETIVO } \\
\text { A ELABORAçãO DE UM PLANO } \\
\text { DIRETRR DE ESGOTO SANITáRIO, } \\
\text { VISANDO EXECUTA }\end{array}$ \\
\hline $\begin{array}{l}\text { PREFEITURA } \\
\text { MUNICIPALDE } \\
\text { QUADRA }\end{array}$ & $\begin{array}{l}\text { PREFEITURA } \\
\text { MUNICIPAL }\end{array}$ & Cancelado & 10/04/2013 & 0 & 0 & 0 & Município & Não reemb. & $\begin{array}{l}\text { Planej. e Gerenc. } \\
\text { dos Recs. Hídricos } \\
\text { (contratos) }\end{array}$ & 3286 & PDC09 & 6 & $\begin{array}{l}\text { O PLANO DIERETOR DE } \\
\text { MACRODRENAGEM E CONTROLE DE } \\
\text { EROSÃO RURAL DO MUNICIPIO DE } \\
\text { QUADRA TERá POR OBJETIV }\end{array}$ \\
\hline $\begin{array}{l}\text { FUNDAÇÃO DE } \\
\text { APOIO INSTIT.AO } \\
\text { DESENV.CIENTÍFICO }\end{array}$ & $\begin{array}{c}\text { APOIO } \\
\text { INSTITUCIONAL AO } \\
\text { DESENVOLVIMENTO }\end{array}$ & Cancelado & 26/03/2013 & 0 & 0 & 0 & Sociedade Civil & Não reemb. & $\begin{array}{l}\text { Estudos/Projetos } \\
\text { (contratos) }\end{array}$ & 20000 & PDC01 & 24 & $\begin{array}{l}\text { O OBJETIVO GERAL ENVOLVEO } \\
\text { DESENVOLVIMENTO DE MODELOS } \\
\text { INTEGRADOS QUE PERMITA A }\end{array}$ \\
\hline $\begin{array}{c}\text { FUNDACC̃̃̃O DE } \\
\text { APOIO INSTIT.AO } \\
\text { DESENV.CIENTÍFICO } \\
\text { ETECNOL.DA } \\
\text { UNIVERS.FEDERAL } \\
\text { DE SÃO CARLOS (FAI- } \\
\text { UFSCar) }\end{array}$ & $\begin{array}{c}\text { APOIO } \\
\text { INSTITUCIONALAO } \\
\text { DESENVOLVIMENTO } \\
\text { CIENTÍFICO E } \\
\text { TECNOLÓGICO DA }\end{array}$ & Cancelado & 10/04/2013 & 0 & 0 & 0 & Sociedade Civil & Não reemb. & $\begin{array}{l}\text { Estudos/Projetos } \\
\text { (contratos) }\end{array}$ & 1717000 & $\mathrm{PDC}_{3}$ & 36 & $\begin{array}{l}\text { ESTE PROJETO TEM COMO OBJETIVO } \\
\text { AVALIAR A CONDIçãO AMBIENTAL } \\
\text { DA BACAA DE DRENAGEM DA } \\
\text { REPRESA DE ITUPA }\end{array}$ \\
\hline $\begin{array}{l}\text { PREFEITURA } \\
\text { MUNICIPALDE } \\
\text { CAPELA DO ALTO }\end{array}$ & $\begin{array}{l}\text { PREFEITURA } \\
\text { MUNICIPAL }\end{array}$ & Cancelado & 10/04/2013 & 0 & 0 & 0 & Município & Não reemb. & $\begin{array}{l}\text { Trat. e Disposição } \\
\text { de Lixo - Obras } \\
\text { (habitantes) }\end{array}$ & 17871 & $\mathrm{PDC}_{3}$ & 6 & $\begin{array}{l}\text { OBJETIVO REFORMA E AMPLIAção DE } \\
\text { USINA DE RECICLAGEM } \\
\text { JUSTIFICATIVA (2.3 - PROTEÇÃO, } \\
\text { CONSERVAÇÃO E RE }\end{array}$ \\
\hline $\begin{array}{l}\text { PREFEITURA } \\
\text { MUNICIPALDE } \\
\text { QUADRA }\end{array}$ & $\begin{array}{l}\text { PREFEITURA } \\
\text { MUNICIPAL }\end{array}$ & Cancelado & 10/04/2013 & 0 & 0 & 0 & Município & Não reemb. & $\begin{array}{l}\text { Trat. e Disposição } \\
\text { de Lixo - Obras } \\
\text { (habitantes) }\end{array}$ & 3286 & $\mathrm{PDC} 03$ & 7 & $\begin{array}{c}\text { REDUZIR O EFEITO CONTAMINANTE } \\
\text { DO SOLO EDA áGUA NA REGlãO DO } \\
\text { ATERRO SANITáRIO, AUMENTANDO A } \\
\text { VIDA úTI }\end{array}$ \\
\hline $\begin{array}{c}\text { PREFEITURA } \\
\text { MUNICIPALDE } \\
\text { CAPELA DO ALTO }\end{array}$ & $\begin{array}{l}\text { PREFEITURA } \\
\text { MUNICIPAL }\end{array}$ & Concluído & $11 / 05 / 2015$ & $145.975,30$ & $2.462,37$ & $148.437,67$ & Município & Não reemb. & $\begin{array}{l}\text { Trat. e Disposição } \\
\text { de Lixo - Obras } \\
\text { (habitantes) }\end{array}$ & 17871 & $\mathrm{PDC} 03$ & 4 & $\begin{array}{l}\text { ENCERRAR ADEQUADAMENTE AS } \\
\text { ATIVIDADES DE DISPOSIIç̃o DE } \\
\text { RESiDUOS, CONFIGURAR OS TALUDES } \\
\text { DE FORMA GEOTE }\end{array}$ \\
\hline $\begin{array}{l}\text { COMPANHIA DE } \\
\text { SANEAMENTO } \\
\text { BÁSICO DO ESTADO } \\
\text { DE SÃO PAULO - } \\
\text { SABESP }\end{array}$ & $\begin{array}{l}\text { SANEAMENTO } \\
\text { BÁSICO }\end{array}$ & Concluído & 04/08/2015 & $400.000,00$ & $140.382,64$ & $540.382,64$ & Estado & Reembolsável & $\begin{array}{l}\text { Estudos/Projetos } \\
\text { (contratos) }\end{array}$ & 28000 & $\mathrm{PDC} 03$ & 12 & $\begin{array}{c}\text { ELABORAR PROJETOS PARA AMPLIAR } \\
\text { O SISTEMA DE ESGOTOS PARA } \\
\text { PRESERVAR A INTEGRIDADE DOS } \\
\text { RIOS, PROPORCIO }\end{array}$ \\
\hline $\begin{array}{l}\text { PREFEITURA DO } \\
\text { MUNICIPIO DE TIETÊ }\end{array}$ & $\begin{array}{l}\text { ADMINISTRAÇÃ̃O } \\
\text { MUNICIPAL }\end{array}$ & Cancelado & 10/04/2013 & 0 & 0 & 0 & Município & Não reemb. & $\begin{array}{l}\text { Estudos/Projetos } \\
\quad \text { (contratos) }\end{array}$ & 36827 & $\mathrm{PDC} 03$ & 6 & $\begin{array}{l}\text { ESTE TRABALHO TEM POR OBJETIVO } \\
\text { A ELABORAç̃̃O DE UM PLANO } \\
\text { DIRETOR DE ESGOTO SANIT́RIO, } \\
\text { VISANDO EXECUTA }\end{array}$ \\
\hline $\begin{array}{c}\text { CONSÓRCIO DE } \\
\text { ESTUDOS, } \\
\text { RECUPERAÇÃO E } \\
\text { DESENVOLVIMENTO } \\
\text { DA BACIA DOS RIOS } \\
\text { SOROCABA EMÉDIO } \\
\text { TIETÊ - CERISO }\end{array}$ & $\begin{array}{c}\text { CONSÓRCIO } \\
\text { INTERMUNICIPAL }\end{array}$ & Emexecução & & $194.000,00$ & 0 & $194.000,00$ & Sociedade Civil & Não reemb. & $\begin{array}{l}\text { Estudos/Projetos } \\
\text { (contratos) }\end{array}$ & 1800000 & $\mathrm{PDC}_{3}$ & 12 & $\begin{array}{l}\text { OS RELATóRIOS DE SITUAção, } \\
\text { ELABORADOS ANUAMENTE PELOS } \\
\text { COMITASS DE BACAA, São } \\
\text { IMPORTANTES INSTRUMENTO }\end{array}$ \\
\hline
\end{tabular}




\begin{tabular}{|c|c|c|c|c|c|c|c|c|c|c|c|c|c|}
\hline Nome do interessado & $\begin{array}{l}\text { Atividade principal do } \\
\text { interessado }\end{array}$ & $\begin{array}{l}\text { Situação do } \\
\text { empreendimento }\end{array}$ & $\begin{array}{l}\text { Data de } \\
\text { conclusão }\end{array}$ & Valor aprovado & $\begin{array}{c}\text { Valor de } \\
\text { contrapartida }\end{array}$ & Valor total & $\begin{array}{l}\text { Segmento do } \\
\text { interessado }\end{array}$ & Modalidade & $\begin{array}{l}\text { Benefício: } \\
\text { indicador }\end{array}$ & $\begin{array}{l}\text { População } \\
\text { beneficiada }\end{array}$ & PDC: sigla & $\begin{array}{l}\text { Tempo de } \\
\text { execução } \\
\text { (meses) }\end{array}$ & Descrição \\
\hline $\begin{array}{c}\text { SOS } \\
\text { ITUPARARANGA - }\end{array}$ & $\begin{array}{l}\text { PROTEÇÃO DOS } \\
\text { RECURSOS }\end{array}$ & Cancelado & $26 / 03 / 2013$ & 0 & 0 & 0 & Sociedade Civil & Não reemb. & $\begin{array}{l}\text { Estudos/Projetos } \\
\text { (contratos) }\end{array}$ & 10000 & PDC01 & 10 & $\begin{array}{l}\text { OBJETIVO: O OBJETIVO DESTE } \\
\text { PROJETO é DIAGNOSTICAR PARA } \\
\text { ELABORACãO DO PLA NO DIRETOR DE }\end{array}$ \\
\hline $\begin{array}{l}\text { PREFEITURA } \\
\text { MUNICIPAL DE } \\
\text { BOTUCATU }\end{array}$ & $\begin{array}{l}\text { PREFEITURA } \\
\text { MUNICIPAL }\end{array}$ & Em execução & & $208.946,42$ & $6.761,46$ & $215.707,88$ & Município & Não reemb. & $\begin{array}{l}\text { Estudos/Projetos } \\
\quad \text { (contratos) }\end{array}$ & 129234 & PDC08 & 6 & $\begin{array}{c}\text { ELABORAção DO PLANO DIRETOR DE } \\
\text { DRENAGEM URBANA PARA } \\
\text { CONTROLE DE EROSão DO SOLO E } \\
\text { INUNDAçõES EM áREAS }\end{array}$ \\
\hline $\begin{array}{l}\text { PREFEITURA } \\
\text { MUNICIPALDE } \\
\text { BOFETE }\end{array}$ & $\begin{array}{l}\text { PREFEITURA } \\
\text { MUNICIPAL }\end{array}$ & Cancelado & 10/04/2013 & 0 & 0 & 0 & Município & Não reemb. & $\begin{array}{l}\text { Estudos/Projetos } \\
\quad \text { (contratos) }\end{array}$ & 9858 & PDC08 & 6 & $\begin{array}{c}\text { ELABORAçãO DO PLANO DIRETOR DE } \\
\text { DRENAGEM URBANA PARA } \\
\text { CONTRLEE DE EROSãa DO SOLO E } \\
\text { INUNDAçõES EM áREAS }\end{array}$ \\
\hline $\begin{array}{c}\text { SERVIÇO } \\
\text { AUTONOMO DE } \\
\text { ÁGUA EESGOTO DE } \\
\text { VOTORANTIM - } \\
\text { SAAE }\end{array}$ & $\begin{array}{l}\text { PREFEITURA } \\
\text { MUNICIPAL }\end{array}$ & Cancelado & 10/04/2013 & 0 & 0 & 0 & Município & Não reemb. & $\begin{array}{c}\text { Estudos/Projetos } \\
\text { (contratos) }\end{array}$ & 108810 & PDC08 & 6 & $\begin{array}{l}\text { PLANO DIRETOR DE DRENAGEM } \\
\text { URBANA }\end{array}$ \\
\hline $\begin{array}{l}\text { PREFEITURA } \\
\text { MUNICIPAL DE } \\
\text { MAIRINQUE }\end{array}$ & $\begin{array}{l}\text { PREFEITURA } \\
\text { MUNICIPAL }\end{array}$ & Em execução & & $148.000,00$ & $4.099,00$ & $152.099,00$ & Município & Não reemb. & $\begin{array}{l}\text { Galerias de Águas } \\
\text { Pluviais (metros } \\
\quad \text { lineares) }\end{array}$ & 45000 & PDC08 & 12 & $\begin{array}{l}\text { O OBJETIVO PRINCIPAL DESSE } \\
\text { PROJETO é REALIZAR UM } \\
\text { DIAGNóSTICO DO MEIO FISIICO DE } \\
\text { TODA áREA DO MUNICIPI }\end{array}$ \\
\hline $\begin{array}{l}\text { ASSOCIAÇ̃̃O } \\
\text { ECOAR FLORESTAL }\end{array}$ & $\begin{array}{l}\text { REALIZAÇÃO DE } \\
\text { PROJETOS } \\
\text { SOCIOAMBIENTAIS }\end{array}$ & Cancelado & $26 / 03 / 2013$ & 0 & 0 & 0 & Sociedade Civil & Não reemb. & $\begin{array}{l}\text { Estudos/Projetos } \\
\quad \text { (contratos) }\end{array}$ & 50000 & PDC01 & 24 & $\begin{array}{c}\text { O PRESENTE PROJETO BUSCA } \\
\text { DESENVOLVER AçẼES PARA REVERTER } \\
\text { O ATUAL QUADRO DE DEGRADAção } \\
\text { AMBIENTAL DAS }\end{array}$ \\
\hline $\begin{array}{l}\text { PREFEITURA } \\
\text { MUNICIPALDA } \\
\text { ESTÂNCIA } \\
\text { TURí́STIICA DE } \\
\text { IBIÚNA }\end{array}$ & $\begin{array}{l}\text { PREFEITURA } \\
\text { MUNICIPAL }\end{array}$ & Emexecução & & $184.836,32$ & $15.919,77$ & $200.756,09$ & Município & Não reemb. & $\begin{array}{l}\text { Estudos/Projetos } \\
\quad \text { (contratos) }\end{array}$ & 71000 & $\mathrm{PDC} 03$ & 10 & $\begin{array}{c}\text { POR SER UM PROJETO QUE VISA A } \\
\text { CONSERVAçãO DO SOLO E DA áGUA } \\
\text { SUBTERRÂNEA E } \\
\text { CONSEQUENTEMENTE DOS CORPO }\end{array}$ \\
\hline $\begin{array}{l}\text { PREFEITURA } \\
\text { MUNICIPALDA } \\
\text { ESTÂNCIA } \\
\text { TURÍSTICA DE } \\
\text { IBIUUNA }\end{array}$ & $\begin{array}{l}\text { PREFEITURA } \\
\text { MUNICIPAL }\end{array}$ & Cancelado & 10/04/2013 & 0 & 0 & 0 & Município & Não reemb. & $\begin{array}{l}\text { Estudos/Projetos } \\
\quad \text { (contratos) }\end{array}$ & 500 & PDC09 & 18 & $\begin{array}{l}\text { ELABORAR O PROJETO EXECUTIVO } \\
\text { PARA RECUPERAçãO FLORESTAL DAS } \\
\text { NASCENTES PRIORITáRIAS à CONEXãO } \\
\text { DE FRAG }\end{array}$ \\
\hline $\begin{array}{l}\text { PREFEITURA } \\
\text { MUNICIPALDE } \\
\text { TATUII }\end{array}$ & $\begin{array}{l}\text { PREFEITURA } \\
\text { MUNICIPAL }\end{array}$ & Emexecução & - & $33.196,00$ & $1.750,00$ & $34.946,00$ & Município & Não reemb. & $\begin{array}{l}\text { Coleta e } \\
\text { Tratamento de } \\
\text { Esgotos } \\
\text { (habitantes) }\end{array}$ & 100 & PDC03 & 3 & $\begin{array}{l}\text { O OBJETIVO é TRATAR O ESGOTO } \\
\text { DOMÉSTICO PRODUZIDO NAS } \\
\text { RESIDêNCIAS RURAIS, REDUZINDO } \\
\text { CONSIDERAVELMENTE }\end{array}$ \\
\hline $\begin{array}{l}\text { PREFEITURA } \\
\text { MUNICIPALDA } \\
\text { ESTÂNCIA } \\
\text { TURÍSTICA DE } \\
\text { IBIUUNA }\end{array}$ & $\begin{array}{l}\text { PREFEITURA } \\
\text { MUNICIPAL }\end{array}$ & Cancelado & $10 / 04 / 2013$ & 0 & 0 & 0 & Município & Não reemb. & $\begin{array}{l}\text { Estudos/Projetos } \\
\text { (contratos) }\end{array}$ & 71244 & PDC08 & 10 & $\begin{array}{l}\text { O PRESENTE PROJETO VISA A } \\
\text { ELABORAçãO DO PLANO DIRETOR DE } \\
\text { DRENAGEM URBANA PARA O } \\
\text { DIMENSIONAMENTO DOS }\end{array}$ \\
\hline $\begin{array}{l}\text { PREFEITURA } \\
\text { MUNICIPALDE } \\
\text { LARANJAL } \\
\text { PAULISTA }\end{array}$ & $\begin{array}{l}\text { PREFEITURA } \\
\text { MUNICIPAL }\end{array}$ & Cancelado & 10/04/2013 & 0 & 0 & 0 & Município & Não reemb. & $\begin{array}{l}\text { Trat. e Disposicicão } \\
\text { de Lixo - Obras } \\
\text { (habitantes) }\end{array}$ & 26640 & PDC03 & 6 & $\begin{array}{l}\text { O MUNICIPIO DE LARANJAL PAULISTA } \\
\text { - SP, NECESSITA QUE SEJA } \\
\text { EXECUTADO O ENCERRAMENTO. ESTE } \\
\text { PROJETO Á A }\end{array}$ \\
\hline $\begin{array}{l}\text { PREFEITURA } \\
\text { MUNICIPALDE } \\
\text { LARANJAL } \\
\text { PAULISTA }\end{array}$ & $\begin{array}{l}\text { PREFEITURA } \\
\text { MUNICIPAL }\end{array}$ & Cancelado & 10/04/2013 & 0 & 0 & 0 & Município & Não reemb. & $\begin{array}{l}\text { Trat. e Disposiç̃ão } \\
\text { de Lixo - Obras } \\
\text { (habitantes) }\end{array}$ & 26640 & PDC03 & 6 & $\begin{array}{l}\text { DIMINUIR A PERMANêNCIA DE } \\
\text { RESiDUOS SóLIDOS URBANOS, DO } \\
\text { MUNICIPIO E EVITANDO ASSIM A } \\
\text { POSSIBILIDADE DE }\end{array}$ \\
\hline $\begin{array}{l}\text { PREFEITURA DA } \\
\text { ESTâNCIA } \\
\text { TURíSTICA DE São } \\
\text { ROQUE }\end{array}$ & $\begin{array}{l}\text { ADMINISTRAção } \\
\text { PúBLICA } \\
\text { MUNICIPAL }\end{array}$ & Cancelado & 10/04/2013 & 0 & 0 & 0 & Município & Não reemb. & $\begin{array}{l}\text { Coleta e } \\
\text { Tratamento de } \\
\text { Esgotos } \\
\text { (habitantes) }\end{array}$ & 810 & PDC03 & 12 & $\begin{array}{c}\text { DAR DESTINAç̃̃o ADEQUADA AO } \\
\text { ESGOTO COLETADO NAS } \\
\text { RESIDêNCIAS, DE FORMA E NãO } \\
\text { CONTAMINAR O SOLO, LENÇOL }\end{array}$ \\
\hline $\begin{array}{l}\text { SOS } \\
\text { ITUPARARANGA - } \\
\text { ORGANIZAÇÃO DA } \\
\text { SOCIEDADECIVIL DE } \\
\text { INTERESSE PÚBLICO }\end{array}$ & $\begin{array}{l}\text { PROTEČÃO DOS } \\
\text { RECURSOS } \\
\text { HÍDRICOS E } \\
\text { PROJETOS DE } \\
\text { EDUCAÇÃO } \\
\text { AMBIENTAL }\end{array}$ & Cancelado & 10/04/2013 & 0 & 0 & 0 & Sociedade Civil & Não reemb. & $\begin{array}{c}\text { Estudos/Projetos } \\
\text { (contratos) }\end{array}$ & 70000 & PDC01 & 12 & $\begin{array}{l}\text { REALIZAR UM LEVANTAMENTO E A } \\
\text { ESPACIALIZAção DAS INFORMAçõES } \\
\text { SOBRECAPTAçãO DE áGUAA E } \\
\text { DESCARTEDOS EF }\end{array}$ \\
\hline
\end{tabular}




\begin{tabular}{|c|c|c|c|c|c|c|c|c|c|c|c|c|c|}
\hline Nome do interessado & $\begin{array}{l}\text { Atividade principal do } \\
\text { interessado }\end{array}$ & $\begin{array}{l}\text { Situação do } \\
\text { empreendimento }\end{array}$ & $\begin{array}{l}\text { Data de } \\
\text { conclusão }\end{array}$ & Valor aprovado & $\begin{array}{c}\text { Valor de } \\
\text { contrapartida }\end{array}$ & Valor total & $\begin{array}{l}\text { Segmento do } \\
\text { interessado }\end{array}$ & Modal idade & $\begin{array}{l}\text { Benefício: } \\
\text { indicador }\end{array}$ & $\begin{array}{l}\text { População } \\
\text { beneficiada }\end{array}$ & PDC: sigla & $\begin{array}{l}\text { Tempo de } \\
\text { execução } \\
\text { (meses) }\end{array}$ & Descrição \\
\hline $\begin{array}{c}\text { SERVIÇO } \\
\text { AUTÔNOMO DE } \\
\text { ÁGUA EESGOTO DE } \\
\text { CERQULHO }\end{array}$ & $\begin{array}{l}\text { SERVIÇO DE } \\
\text { SANEMEETO } \\
\text { BÁSICO }\end{array}$ & Concluído & 16/02/2016 & $357.765,86$ & $1.331 .675,50$ & $1.689 .441,36$ & Município & Não reemb. & $\begin{array}{c}\text { Coleta e } \\
\text { Tratamento de } \\
\text { Esgotos } \\
\text { (habitantes) }\end{array}$ & 28826 & PDC03 & 10 & $\begin{array}{l}\text { A AMPLIAç̃̃o DA ETE RIO SOROCABA, } \\
\text { POR MEIO DA IMPLANTAçãO DO } 4^{\circ} \\
\text { MóDULO DE LAGOAS, GARANTIRá O } \\
\text { TRATAME }\end{array}$ \\
\hline $\begin{array}{l}\text { SERVIÇO } \\
\text { AUTÔNOMO DE } \\
\text { ÁGUA EESGOTO DE } \\
\text { CERQULHLO }\end{array}$ & $\begin{array}{l}\text { SERVIÇO DE } \\
\text { SANEAMENTO } \\
\text { BÁSICO }\end{array}$ & Cancelado & 10/04/2013 & 0 & 0 & 0 & Município & Não reemb. & $\begin{array}{l}\text { Coleta e } \\
\text { Tratamento de } \\
\text { Esgotos } \\
\text { (habitantes) }\end{array}$ & 12500 & PDC03 & 5 & $\begin{array}{c}\text { A LIMPEZA DAS LAGOAS ANAERóBIA } \\
\text { EFACULTATIVA DA ETE ALIANçA E E } \\
\text { DA LAGOA ANAERóBIA DA ETE } \\
\text { TAQUARALATR }\end{array}$ \\
\hline $\begin{array}{l}\text { PREFEITURA } \\
\text { MUNICIPALDE } \\
\text { CERQULILHO }\end{array}$ & $\begin{array}{l}\text { PREFEITURA } \\
\text { MUNICIPAL }\end{array}$ & Concluído & 19/10/2015 & $379.489,89$ & $87.089,11$ & $466.579,00$ & Município & Não reemb. & $\begin{array}{l}\text { Trat. e Disposicião } \\
\text { de Lixo - Obras } \\
\text { (habitantes) }\end{array}$ & 39649 & PDC03 & 6 & $\begin{array}{c}\text { O EMPREENDIMENTO ESTá } \\
\text { ENQUADRADO NO PDC 03 QUEFAZ } \\
\text { PARTE DO ESCOPO DOS PROGRAMAS } \\
\text { DE DURAção CONTINUA }\end{array}$ \\
\hline $\begin{array}{c}\text { CONSÓRCIO DE } \\
\text { ESTUDOS, } \\
\text { RECUPERAÇÃOO E } \\
\text { DESENVOLVIMENTO } \\
\text { DA BACIA DOS RIOS } \\
\text { SOROCABA EMÉDIO } \\
\text { TIETÊ- CERISO }\end{array}$ & $\begin{array}{c}\text { CONSÓRCIO } \\
\text { INTERMUNICIPAL }\end{array}$ & Cancelado & 04/01/2017 & $700.000,00$ & 0 & $700.000,00$ & Sociedade Civil & Não reemb. & $\begin{array}{l}\text { Planej. e Gerenc. } \\
\text { dos Recs. Hídricos } \\
\text { (contratos) }\end{array}$ & 1600000 & PDC01 & 15 & $\begin{array}{l}\text { PROPOR AS PRINCIPAIS DIRETRIZES, } \\
\text { ESTRATéGiAS DE EXECUção E } \\
\text { PRODUTSOS BáSICOS A SEREM } \\
\text { CONSIDERADOS EO }\end{array}$ \\
\hline $\begin{array}{l}\text { PREFEITURA } \\
\text { MUNICIPAL DA }\end{array}$ & $\begin{array}{l}\text { PREFEITURA } \\
\text { MUNICIPAL }\end{array}$ & Cancelado & 16/03/2016 & $77.349,92$ & $6.491,00$ & $83.840,92$ & Município & Não reemb. & $\begin{array}{l}\text { Estudos/Projetos } \\
\quad \text { (contratos) }\end{array}$ & 71000 & PDC01 & 8 & $\begin{array}{l}\text { PORTANTO, ENTENDE-SE QUE PARA } \\
\text { QUE SEJA CRIADA UMA LEI }\end{array}$ \\
\hline $\begin{array}{l}\text { PREFEITURA } \\
\text { MUNICIPALDA } \\
\text { ESTÂNCAA } \\
\text { TURí́TTIIA DE } \\
\text { IBIÚNA }\end{array}$ & $\begin{array}{l}\text { PREFEITURA } \\
\text { MUNICIPAL }\end{array}$ & Emexecução & - & $306.016,95$ & $7.195,01$ & $313.211,96$ & Município & Não reemb. & $\begin{array}{l}\text { Estudos/Projetos } \\
\text { (contratos) }\end{array}$ & 71244 & PDC08 & 12 & $\begin{array}{c}\text { CONFORME APRESENTADO, AS AçōES } \\
\text { DE CHUVAS INTENSAS ATINGEM } \\
\text { DIVERSOS PONTOS DA CIDADE. O } \\
\text { MUNICIPIO DE }\end{array}$ \\
\hline $\begin{array}{l}\text { PREFEITURA } \\
\text { MUNICIPAL DA } \\
\text { ESTÂNCIA } \\
\text { TURÍSTIIA DE } \\
\text { IBIUUNA }\end{array}$ & $\begin{array}{l}\text { PREFEITURA } \\
\text { MUNICIPAL }\end{array}$ & Cancelado & 16/03/2016 & 199.369,68 & $20.080,00$ & $219.449,68$ & Município & Não reemb. & $\begin{array}{l}\text { Educação } \\
\text { Ambiental } \\
\text { (contratos) }\end{array}$ & 20000 & PDC01 & 12 & $\begin{array}{c}\text { TAL PROJETO é FUNDAMENTAL UMA } \\
\text { VEZ QUE ENRIQUECERá } \\
\text { PROVIDENCIALMENTE O PROGRAMA } \\
\text { SOCIOAMBIENTAL MUNICI }\end{array}$ \\
\hline $\begin{array}{l}\text { PREFEITURA } \\
\text { MUNICIPALDE } \\
\text { TATUÍ }\end{array}$ & $\begin{array}{l}\text { PREFEITURA } \\
\text { MUNICIPAL }\end{array}$ & Emexecução & - & $609.974,74$ & $20.831,50$ & $630.806,24$ & Município & Não reemb. & Outros (contratos) & 221000 & PDC03 & 12 & $\begin{array}{l}\text { ENCERRAMENTO DO ATERRO DE } \\
\text { TATUÍ, ADEQUANDO AS } \\
\text { INCONFORMIDADES AMBIENTAIS DA } \\
\text { ÁREA DO ATERRO DESATIVAD }\end{array}$ \\
\hline $\begin{array}{l}\text { PREFEITURA } \\
\text { MUNICIPALDE } \\
\text { TATUÍ }\end{array}$ & $\begin{array}{l}\text { PREFEITURA } \\
\text { MUNICIPAL }\end{array}$ & Cancelado & 30/04/2014 & 0 & 0 & 0 & Município & Não reemb. & $\begin{array}{l}\text { Educação } \\
\text { Ambiental } \\
\text { (contratos) }\end{array}$ & 113000 & PDC01 & 12 & $\begin{array}{l}\text { ESTE PROJETO PREVÊA A } \\
\text { IMPLANTACCÃO DE PRÁTICAS } \\
\text { SUSTENTÁVEIS QUE VISEM OS } \\
\text { RESÍDUOS SÓLIDOS E A ÁGGA, AT }\end{array}$ \\
\hline $\begin{array}{l}\text { PREFEITURA } \\
\text { MUNICIPAL DE } \\
\text { CAPELA DO ALTO }\end{array}$ & $\begin{array}{l}\text { PREFEITURA } \\
\text { MUNICIPAL }\end{array}$ & Emexecução & - & $141.481,60$ & $7.255,00$ & $148.736,60$ & Município & Não reemb. & $\begin{array}{l}\text { Galerias de Águas } \\
\text { Pluviais (metros } \\
\quad \text { lineares) }\end{array}$ & 15532 & PDC01 & 7 & $\begin{array}{l}\text { O PLANO DIRETOR DE } \\
\text { MACRODRENAGEM DO MUNICIPIO DE } \\
\text { CAPELA DO ALTO - SP TEM COMO } \\
\text { OBJETIVO CARACTERIZAR }\end{array}$ \\
\hline $\begin{array}{l}\text { PREFEITURA } \\
\text { MUNICIPALDDE } \\
\text { IPERÓ }\end{array}$ & $\begin{array}{l}\text { PREFEITURA } \\
\text { MUNICIPAL }\end{array}$ & Em execução & - & $140.644,65$ & $7.402,35$ & $148.047,00$ & Município & Não reemb. & $\begin{array}{l}\text { Abastecimento de } \\
\text { Água (habitantes) }\end{array}$ & 28300 & PDC05 & 6 & $\begin{array}{l}\text { ESTE TERMO DE REFERêNCIA TEM POR } \\
\text { OBJETIVO FORNECER AS DIRETRIZES } \\
\text { PARA A CONTRATAção DE SERVIçOS } \\
\text { DEE }\end{array}$ \\
\hline $\begin{array}{l}\text { PREFEITURA } \\
\text { MUNICIPALDE } \\
\text { VARGEM GRANDE } \\
\text { PAULISTA }\end{array}$ & $\begin{array}{l}\text { PREFEITURA } \\
\text { MUNICIPAL }\end{array}$ & Em execução & & $84.365,70$ & $2.187,66$ & $86.553,36$ & Município & Não reemb. & $\begin{array}{l}\text { Estudos/Projetos } \\
\text { (contratos) }\end{array}$ & 45000 & PDC03 & 3 & $\begin{array}{l}\text { OBJETIVO: DETERMINAR SE ́́́REA } \\
\text { AINDA APRESENTA RISCO DE } \\
\text { CONTAMINAçãO AMBIENTALE } \\
\text { AVALIAR A EFICáCIA DA DA }\end{array}$ \\
\hline $\begin{array}{l}\text { PREFEITURA } \\
\text { MUNICIPALDE } \\
\text { PORTO FELIZ }\end{array}$ & $\begin{array}{l}\text { PREFEITURA } \\
\text { MUNICIPAL }\end{array}$ & Concluído & 18/07/2016 & $288.000,00$ & $17.280,00$ & $305.280,00$ & Município & Não reemb. & $\begin{array}{l}\text { Planej. e Gerenc. } \\
\text { dos Recs. Hídricos } \\
\text { (contratos) }\end{array}$ & 48893 & PDC01 & 18 & $\begin{array}{l}\text { OBJETIVO: IMPLANTAR O PROCESSO } \\
\text { DE CRIAçãO DO CONSELHO GESTOR } \\
\text { PARA QUE SE TORNE UM óRGăO } \\
\text { ATUANTE DE G }\end{array}$ \\
\hline $\begin{array}{l}\text { PREFEITURA } \\
\text { MUNICIPALDE } \\
\text { JUMIRIM }\end{array}$ & $\begin{array}{l}\text { PREFEITURA } \\
\text { MUNICIPAL }\end{array}$ & Cancelado & $30 / 04 / 2014$ & 0 & 0 & 0 & Município & Não reemb. & $\begin{array}{l}\text { Abastecimento de } \\
\text { Aggua (habitantes) }\end{array}$ & 2798 & PDC01 & 4 & $\begin{array}{l}\text { O OBJETIVO DESSE TERMO DE } \\
\text { REFEReNCIA é A CONTRATAção DE } \\
\text { SERVIçOS PROFISSIONAIS } \\
\text { ESPECIALIZADOS PARA A }\end{array}$ \\
\hline
\end{tabular}




\begin{tabular}{|c|c|c|c|c|c|c|c|c|c|c|c|c|c|}
\hline Nome do interessado & $\begin{array}{l}\text { Atividade principal do } \\
\text { interessado }\end{array}$ & $\begin{array}{l}\text { Situação do } \\
\text { empreendimento }\end{array}$ & $\begin{array}{l}\text { Data de } \\
\text { conclusão }\end{array}$ & Valor aprovado & $\begin{array}{c}\text { Valor de } \\
\text { contrapartida }\end{array}$ & Valor total & $\begin{array}{l}\text { Segmento do } \\
\text { interessado }\end{array}$ & Modalidade & $\begin{array}{l}\text { Benefício: } \\
\text { indicador }\end{array}$ & $\begin{array}{c}\text { Populacacão } \\
\text { beneficiada }\end{array}$ & PDC: sigla & $\begin{array}{l}\text { Tempo de } \\
\text { execução } \\
\text { (meses) }\end{array}$ & Descrição \\
\hline $\begin{array}{l}\text { PREFEITURA DO } \\
\text { MUNICIPIO DE TIETÊ }\end{array}$ & $\begin{array}{l}\text { ADMINISTRAÇÃO } \\
\text { MUNICIPAL }\end{array}$ & Emexecução & - & $134.154,83$ & $14.665,37$ & $148.820,20$ & Município & Não reemb. & $\begin{array}{l}\text { Estudos/Projetos } \\
\text { (contratos) }\end{array}$ & 36827 & PDC08 & 6 & $\begin{array}{l}\text { ESTE TRABALHO TEM POR OBJETIVO } \\
\text { A ELABORAçãO DE UM PLANO } \\
\text { DIRETRR DE MACRODREAGEM } \\
\text { URBANA, VISANDO EXE }\end{array}$ \\
\hline $\begin{array}{l}\text { PREFEITURA } \\
\text { MUNIIIPALDE } \\
\text { VOTORANTIM }\end{array}$ & $\begin{array}{l}\text { PREFEITURA } \\
\text { MUNICIPAL }\end{array}$ & Cancelado & $30 / 04 / 2014$ & $140.832,75$ & $7.412,25$ & $148.245,00$ & Município & Não reemb. & $\begin{array}{l}\text { Planej. e Gerenc. } \\
\text { dos Recs. Hidricos } \\
\text { (contratos) }\end{array}$ & 40000 & PDC01 & 7 & $\begin{array}{l}\text { OBJETIVO: ESCOAMENTO HIDRICO, } \\
\text { TENDO COMO SISTEMAS DE ANáLISE: } \\
\text { O SISTEMA DE CONTROLEE DA } \\
\text { DRENAGEM EES }\end{array}$ \\
\hline $\begin{array}{l}\text { IPESA - INSTITUTO } \\
\text { DE PROJETOS E } \\
\text { PESQUISAS } \\
\text { SOCIOAMBIENTAIS }\end{array}$ & MEIO AMBIENTE & Emexecução & - & $194.002,00$ & 0 & $194.002,00$ & Sociedade Civil & Não reemb. & $\begin{array}{l}\text { Estudos/Projetos } \\
\text { (contratos) }\end{array}$ & 12000 & PDC01 & 12 & $\begin{array}{c}\text { SEGUNDO O RELAToRIO ZERO AS } \\
\text { DEMANDAS PARA ABASTEIMENTO } \\
\text { PúBLICO MEDIANTEA AAPTAÇão DE } \\
\text { aGUAS SUPERFI }\end{array}$ \\
\hline $\begin{array}{l}\text { IPESA - INSTITUTO } \\
\text { DE PROJETOS E } \\
\text { PESQUISAS } \\
\text { SOCIOAMBIENTAIS }\end{array}$ & MEIO AMBIENTE & Em execução & - & $194.002,00$ & 0 & $194.002,00$ & Sociedade Civil & Não reemb. & $\begin{array}{l}\text { Estudos/Projetos } \\
\text { (contratos) }\end{array}$ & 8000 & PDC01 & 12 & $\begin{array}{c}\text { SEGUNDO O RELATóRIO ZERO AS } \\
\text { DEMANDAS PARA ABASTECIMENTO } \\
\text { PúBLICO MEDIANTE A CAPTAção DE } \\
\text { áGUAS SUPERFI }\end{array}$ \\
\hline $\begin{array}{l}\text { SERVIÇO } \\
\text { AUTONNOMO } \\
\text { MUNICIPALDE } \\
\text { ÁGUA EEGOTO DE } \\
\text { TIETÉ-SAMAE } \\
\text { AGÊNCIA }\end{array}$ & $\begin{array}{l}\text { SANEAMENTO } \\
\text { PÚBLICO }\end{array}$ & Cancelado & $30 / 04 / 2014$ & $398.136,93$ & $126.387,73$ & $524.524,66$ & Município & Não reemb. & $\begin{array}{l}\text { Abastecimento de } \\
\text { Água (habitantes) }\end{array}$ & 36835 & PDC05 & 6 & $\begin{array}{l}\text { O OBJETIVO DO PRESENTE TRABALHO } \\
\text { é IMPLANTAR ATIVIDADES QUE } \\
\text { VISAM O CONTROLE EREDUção DAS } \\
\text { PERDAS DE }\end{array}$ \\
\hline $\begin{array}{l}\text { REGULADORA DE } \\
\text { SERVIÇOS } \\
\text { DELEGADOS DO } \\
\text { MUNICÍPIO DA } \\
\text { ESTÂNCIA } \\
\text { TURÍSTICA DE ITU - } \\
\text { AR-ITU }\end{array}$ & $\begin{array}{l}\text { SANEAMENTO } \\
\text { BÁSICO }\end{array}$ & Cancelado & 30/04/2014 & 0 & 0 & 0 & Município & Não reemb. & $\begin{array}{l}\text { Planej.e Gerenc. } \\
\text { dos Recs. Hídricos } \\
\text { (contratos) }\end{array}$ & 70000 & PDC01 & 12 & $\begin{array}{c}\text { O OBJETIVO ESPECÍFICO (ÊANFASE) ÉO } \\
\text { DE EFETUAR ESTUDO, A L LUZ DAS } \\
\text { INTERFERÊNCIAS ANTROOPICAS, DE } \\
\text { CARACT }\end{array}$ \\
\hline $\begin{array}{c}\text { AGÊNCIA } \\
\text { REGULADORA DE } \\
\text { SERVIÇOS } \\
\text { DELEGADOS DO } \\
\text { MUNIĆ́PIO DA } \\
\text { ESTÂNCIA } \\
\text { TURÍSTICA DE ITU - } \\
\text { AR-ITU }\end{array}$ & $\begin{array}{l}\text { SANEAMENTO } \\
\text { BÁSICO }\end{array}$ & Cancelado & $30 / 04 / 2014$ & 0 & 0 & 0 & Município & Não reemb. & $\begin{array}{l}\text { Planej. e Gerenc. } \\
\text { dos Recs. Hidricos } \\
\text { (contratos) }\end{array}$ & 34700 & PDC09 & 24 & $\begin{array}{l}\text { RECUPERAR } 12 \text { HA DA BACIA DO } \\
\text { CÓRREGO ITAINZINHO COM PLANTIO } \\
\text { DIRETO DE 20.000 MUDAS E O DE } \\
\text { DESENVOLVER }\end{array}$ \\
\hline $\begin{array}{l}\text { PREFEITURA } \\
\text { MUNICIPAL DE } \\
\text { LARANJAL } \\
\text { PAULISTA }\end{array}$ & $\begin{array}{l}\text { PREFEITURA } \\
\text { MUNICIPAL }\end{array}$ & Em execução & - & $385.082,24$ & $7.014,35$ & $392.096,59$ & Município & Não reemb. & $\begin{array}{l}\text { Trat. e Disposição } \\
\text { de Lixo - Obras } \\
\text { (habitantes) }\end{array}$ & 26640 & $\mathrm{PDCO}_{3}$ & 6 & $\begin{array}{l}\text { O OBJETO DOS ESTUDOS E PROJETOS é } \\
\text { O ENCERRAMENTO QUECONSISTE DE } \\
\text { CONJUNTO DE PROCEDIMENTOS, } \\
\text { SERVIÇOS }\end{array}$ \\
\hline $\begin{array}{c}\text { PREFEITURA } \\
\text { MUNICIPALDE } \\
\text { CONCHAS }\end{array}$ & $\begin{array}{l}\text { PREFEITURA } \\
\text { MUNICIPAL }\end{array}$ & Emexecução & & $136.657,86$ & $1.500,00$ & $138.157,86$ & Município & Não reemb. & $\begin{array}{l}\text { Estudos/Projetos } \\
\text { (contratos) }\end{array}$ & 16451 & PDC09 & 9 & $\begin{array}{l}\text { PREVENÇÃO E DEFFESA CONTRA } \\
\text { EVENTOS HIDROLÓGICOS EXTREMOS }\end{array}$ \\
\hline $\begin{array}{c}\text { CONSÓRCIO DE } \\
\text { ESTUDOS, } \\
\text { RECUERAÇÃO E } \\
\text { DESENVOLVIMENTO }\end{array}$ & $\begin{array}{l}\text { CONSÓRCIO } \\
\text { INTERMUNICIPAL }\end{array}$ & Cancelado & 16/03/2016 & $224.470,60$ & $126.470,50$ & $350.941,10$ & Sociedade Civil & Não reemb. & $\begin{array}{l}\text { Estudos/Projetos } \\
\text { (contratos) }\end{array}$ & 400000 & PDC01 & 9 & $\begin{array}{c}\text { GERENCIAR E PROPOR AçõES EM áREA } \\
\text { DE DRENAGEM DE MANANCIAL DE } \\
\text { ABASTECIMENTO. ÁREA } \\
\text { PERTENCENTE A BACIA }\end{array}$ \\
\hline $\begin{array}{l}\text { PREFEITURA } \\
\text { MUNICIPALDE } \\
\text { BOTUCATU }\end{array}$ & $\begin{array}{l}\text { PREFEITURA } \\
\text { MUNICIPAL }\end{array}$ & Concluído & 07/01/2016 & $141.698,20$ & $4.350,00$ & $146.048,20$ & Município & Não reemb. & $\begin{array}{l}\text { Estudos/Projetos } \\
\quad \text { (contratos) }\end{array}$ & 130183 & PDC09 & 9 & $\begin{array}{l}\text { PREVENÇão E DEFESA CONTRA } \\
\text { EVENTOS HIDROLóGICOS EXTREMOS }\end{array}$ \\
\hline $\begin{array}{l}\text { PREFEITURA } \\
\text { MUNCIPAL DE } \\
\text { CESÁRIO LANGE }\end{array}$ & $\begin{array}{l}\text { PÚBLICA/EXECUTIV } \\
\text { A }\end{array}$ & Concluído & 19/08/2016 & $100.036,44$ & $1.224,94$ & $101.261,38$ & Município & Não reemb. & $\begin{array}{l}\text { Estudos/Projetos } \\
\text { (contratos) }\end{array}$ & 15909 & PDC09 & 9 & $\begin{array}{l}\text { PREVENçãO E DEFESA CONTRA } \\
\text { EVENTOS HIDROLóGICOS EXTREMOS }\end{array}$ \\
\hline $\begin{array}{l}\text { FUNDACÇ̃̃O DE } \\
\text { APOIOINSTTT.AO } \\
\text { DESENV.CIENTIIIICO }\end{array}$ & $\begin{array}{c}\text { APOIO } \\
\text { INSTITUCIONAL AO } \\
\text { DESENVOLVIMENTO }\end{array}$ & Emexecução & - & $301.936,00$ & 0 & $301.936,00$ & Sociedade Civil & Não reemb. & $\begin{array}{l}\text { Planej. e Gerenc. } \\
\text { dos Recs. Hídricos } \\
\text { (contratos) }\end{array}$ & 20000 & PDC01 & 24 & $\begin{array}{l}\text { A COMPATIBLIDADEDO } \\
\text { EMPREENDIMENTO COM O ESCOPO DO } \\
\text { PDC }\end{array}$ \\
\hline $\begin{array}{l}\text { PREFEITURA } \\
\text { MUNICIPALDE } \\
\text { QUADRA }\end{array}$ & $\begin{array}{l}\text { PREFEITURA } \\
\text { MUNICIPAL }\end{array}$ & Concluído & 01/04/2016 & $159.250,00$ & $2.777,43$ & $162.027,43$ & Município & Não reemb. & $\begin{array}{l}\text { Estudos/Projetos } \\
\text { (contratos) }\end{array}$ & 3297 & PDC09 & 12 & $\begin{array}{l}\text { PLANEJAR POLLTICAS PúBLICAS DE } \\
\text { ATENDIMENTO AO MEIO RURAL, } \\
\text { VISANDO A PROTȨã̃O E } \\
\text { CONSERVAção DOS RECUR }\end{array}$ \\
\hline
\end{tabular}




\begin{tabular}{|c|c|c|c|c|c|c|c|c|c|c|c|c|c|}
\hline Nome do interessado & $\begin{array}{l}\text { Atividade principal do } \\
\text { interessado }\end{array}$ & $\begin{array}{c}\text { Situacão do } \\
\text { empreendimento }\end{array}$ & $\begin{array}{l}\text { Data de } \\
\text { conclusão }\end{array}$ & Valor aprovado & $\begin{array}{c}\text { Valor de } \\
\text { contrapartida }\end{array}$ & Valor total & $\begin{array}{l}\text { Segmento do } \\
\text { interessado }\end{array}$ & Modalidade & $\begin{array}{l}\text { Benefício: } \\
\text { indicador }\end{array}$ & $\begin{array}{c}\text { População } \\
\text { beneficiada }\end{array}$ & PDC: sigla & $\begin{array}{c}\text { Tempo de } \\
\text { execucuãa } \\
\text { (meses) }\end{array}$ & Descrição \\
\hline $\begin{array}{l}\text { PREFEITURA } \\
\text { MUNICIPALDE } \\
\text { TATUÍ }\end{array}$ & $\begin{array}{l}\text { PREFEITURA } \\
\text { MUNICIPAL }\end{array}$ & Emexecução & & $194.289,90$ & $1.982,56$ & $196.272,46$ & Município & Não reemb. & $\begin{array}{l}\text { Estudos/Projetos } \\
\text { (contratos) }\end{array}$ & 109799 & PDC01 & (aweses) & $\begin{array}{c}\text { PREVENCCÃO E DEFESA CONTRA } \\
\text { EROSÃO DO SOLO E O } \\
\text { ASSOREAMENTO DOS CORPOS D'ÁGU }\end{array}$ \\
\hline $\begin{array}{l}\text { PREFEITURA } \\
\text { MUNICIPAL DE } \\
\text { TORRE DE PEDRA }\end{array}$ & $\begin{array}{c}\text { PúBLICA/EXECUTIV } \\
\text { A }\end{array}$ & Concluído & 23/03/2016 & $97.179,54$ & $1.320,00$ & 98.499,54 & Município & Não reemb. & $\begin{array}{l}\text { Estudos/Projetos } \\
\text { (contratos) }\end{array}$ & 2266 & PDC09 & 10 & $\begin{array}{c}\text { PREVENç̃̃o E DEFESA CONTRA } \\
\text { EROSãO DO SOLO EO ASSOREAMENTO } \\
\text { DOS CORPOS D'ÁGUA }\end{array}$ \\
\hline $\begin{array}{c}\text { FUNDACCÃO DE } \\
\text { APOIO INSTIT.AO } \\
\text { DESENV.CIENTÍFICO } \\
\text { ETECNOL.DA } \\
\text { UNIVERS.FEDERAL } \\
\text { DE SÃO CARLOS (FAI- } \\
\text { UFSCar) }\end{array}$ & $\begin{array}{c}\text { APOIO } \\
\text { INSTITUCIONAL AO } \\
\text { DESENVOLVIMENTO } \\
\text { CIENTÍFICO E } \\
\text { TECNOLÓGICO DA }\end{array}$ & Em execução & - & $160.371,80$ & 0 & $160.371,80$ & Sociedade Civil & Não reemb. & $\begin{array}{l}\text { Estudos/Projetos } \\
\text { (contratos) }\end{array}$ & 1717000 & $\mathrm{PDC}_{3}$ & 36 & $\begin{array}{l}\text { ESTE PROJETO TEM COMO OBJETIVO } \\
\text { AVALIAR A CONDIçãO AMBIENTAL } \\
\text { DA BACIA DE DRENAGEM DA } \\
\text { REPRESA DE ITUPA }\end{array}$ \\
\hline $\begin{array}{l}\text { SERVICO } \\
\text { AUTONOMO DE } \\
\text { AGUA, ESGOTOE } \\
\text { MEIO AMBIENTE- } \\
\text { SAAEAMBIENTAL }\end{array}$ & $\begin{array}{l}\text { SETOR DE } \\
\text { SANEAMENTO } \\
\text { BáSICO }\end{array}$ & Emexecução & - & $336.633,03$ & $22.583,80$ & $359.216,83$ & Município & Não reemb. & $\begin{array}{l}\text { Planej. e Gerenc. } \\
\text { dos Recs. Hídricos } \\
\text { (contratos) }\end{array}$ & 10000 & PDC05 & 4 & $\begin{array}{c}\text { ESTE EMPREENDIMENTO ESTA } \\
\text { ENQUADRADO NO PDC 05 QUE FAZ } \\
\text { PARTE DO ESCOPO DOS PROGRAMAS } \\
\text { DE DURAçãO CONTI }\end{array}$ \\
\hline $\begin{array}{l}\text { DAAEAMIBIENIAL } \\
\text { PREFEITURA } \\
\text { MUNICIPALDE } \\
\text { LARANJAL } \\
\text { PAULISTA }\end{array}$ & $\begin{array}{l}\text { PREFEITURA } \\
\text { MUNICIPAL }\end{array}$ & Emexecução & - & $358.988,48$ & $7.323,81$ & $366.312,29$ & Município & Não reemb. & $\begin{array}{l}\text { Trat. e Disposiç̃ão } \\
\text { de Lixo - Obras } \\
\text { (habitantes) }\end{array}$ & 26640 & $\mathrm{PDC}_{3}$ & 6 & $\begin{array}{l}\text { DIMINUIR A PERMANêNCIA DE } \\
\text { RESIDUOS SóLEDOS URBANOS, DO } \\
\text { MUNICIIIO E EVITANDO ASSIM A } \\
\text { POSSIBIIIDADEDE }\end{array}$ \\
\hline $\begin{array}{l}\text { PREFEITURA } \\
\text { MUNICIPALDE } \\
\text { CONCHAS }\end{array}$ & $\begin{array}{l}\text { PREFEITURA } \\
\text { MUNICIPAL }\end{array}$ & Cancelado & $30 / 04 / 2014$ & 0 & 0 & 0 & Município & Não reemb. & Outros (contratos) & 16288 & $\mathrm{PDC}_{3}$ & 6 & $\begin{array}{c}\text { O OBJETIVO DESSE TERMO DE } \\
\text { REFERÊNCIA é DAR DIRETRIZES PARA } \\
\text { A CONTRATAç̃̃O DE UM PLANO DE } \\
\text { GERENCIAMENT }\end{array}$ \\
\hline $\begin{array}{c}\text { SERVIÇO } \\
\text { AUTÔNOMO DE } \\
\text { ÁGUA EESGOTO DE } \\
\text { CERQULHLO }\end{array}$ & $\begin{array}{l}\text { SERVIÇO DE } \\
\text { SANEAMENTO } \\
\text { BÁSICO }\end{array}$ & Concluído & 17/06/2016 & $133.335,00$ & $14.627,12$ & $147.962,12$ & Município & Não reemb. & $\begin{array}{l}\text { Coleta e } \\
\text { Tratamento de } \\
\text { Esgotos } \\
\text { (habitantes) }\end{array}$ & 39617 & $\mathrm{PDC}_{3}$ & 6 & $\begin{array}{c}\text { COMO O MUNICIPIO DE CERQUILHO } \\
\text { NãO POSSUI O CADASTRO DAS REDES } \\
\text { DE ESGOTAMENTO SANIT́́RIO, BEM } \\
\text { COMO TAM }\end{array}$ \\
\hline $\begin{array}{l}\text { PREFEITURA DA } \\
\text { ESTâNCIA } \\
\text { TURíSTICA DE São } \\
\text { ROQUE }\end{array}$ & $\begin{array}{l}\text { ADMINISTRAção } \\
\text { PúBLICA } \\
\text { MUNICIPAL }\end{array}$ & Emexecução & - & $349.490,89$ & $90.728,51$ & $440.219,40$ & Município & Não reemb. & $\begin{array}{l}\text { Estudos/Projetos } \\
\text { (contratos) }\end{array}$ & 78821 & PDC01 & 12 & $\begin{array}{l}\text { O OBJETIVO PRINCIPALDA PROPOSTA } \\
\text { é A CONTRATAçãO A ELABORAção DO } \\
\text { PLANO DIREOR AMBIENTAL(PDA) } \\
\text { DO MU }\end{array}$ \\
\hline $\begin{array}{c}\text { SERVIÇO } \\
\text { AUTONOMO DE } \\
\text { ÁGUA EESGOTO DE } \\
\text { CERQUILHO } \\
\text { PREEFITHRA }\end{array}$ & $\begin{array}{c}\text { SERVICCO DE } \\
\text { SANEAMENTO } \\
\text { BÁSICO }\end{array}$ & Concluído & 19/07/2016 & $134.676,00$ & $14.641,60$ & $149.317,60$ & Município & Não reemb. & $\begin{array}{l}\text { Coleta e } \\
\text { Tratamento de } \\
\text { Esgotos } \\
\text { (habitantes) }\end{array}$ & 39617 & PDC01 & 6 & $\begin{array}{c}\text { AS LAGOAS ANAERóBIA E } \\
\text { FACULTATIVA DA ETE ALIANçA E A } \\
\text { LAGOA ANAERóBIA DA ETE } \\
\text { TAQUARAL, AMBAS LOCALIZA }\end{array}$ \\
\hline $\begin{array}{l}\text { MUEICIPALDE } \\
\text { LARANJAL } \\
\text { PAULISTA }\end{array}$ & $\begin{array}{l}\text { PREFEITURA } \\
\text { MUNICIPAL }\end{array}$ & Concluído & 30/03/2017 & $270.658,14$ & $5.523,64$ & $276.181,78$ & Município & Não reemb. & $\begin{array}{c}\text { Canalização } \\
\text { (metros lineares) }\end{array}$ & 3000 & PDC09 & 3 & $\begin{array}{c}\text { PRESERVAR O CURSO DA AGUA DO } \\
\text { RIBEIRÃO LARANJAL DIMINUINDO O } \\
\text { ASSOREAMENTO E AUMENTAR A } \\
\text { SEGURANCA DA P }\end{array}$ \\
\hline $\begin{array}{l}\text { PREFEITURA } \\
\text { MUNICIPAL DE } \\
\text { LARANJAL } \\
\text { PAULISTA }\end{array}$ & $\begin{array}{l}\text { PREFEITURA } \\
\text { MUNICIPAL }\end{array}$ & Cancelado & 16/10/2013 & 0 & 0 & 0 & Município & Não reemb. & $\begin{array}{l}\text { Recomposição de } \\
\text { Mata Ciliar } \\
\text { (hectares) }\end{array}$ & 27000 & PDC09 & 24 & $\begin{array}{l}\text { PRESERVAR OS CURSOS D'AGUA E } \\
\text { AUMENTAR A QUANTIDADE DE } \\
\text { MATA NO MUNICIPIO QUE } \\
\text { ATUALMENTE TEM APROXIMAD }\end{array}$ \\
\hline $\begin{array}{c}\text { SERVICO } \\
\text { AUTONOMO DE } \\
\text { AGUA, ESGOTOE } \\
\text { MEIO AMBIENTE- } \\
\text { SAAE AMBIENTAL }\end{array}$ & $\begin{array}{c}\text { SETOR DE } \\
\text { SANEAMENTO } \\
\text { BáSICO }\end{array}$ & Concluído & 02/09/2016 & $140.600,00$ & $7.388,30$ & $147.988,30$ & Município & Não reemb. & $\begin{array}{l}\text { Estudos/Projetos } \\
\text { (contratos) }\end{array}$ & 105569 & PDC05 & 6 & $\begin{array}{l}\text { ELABORAR O PROJETO DE } \\
\text { RECUPERAçãO E REUSO DAS áGUAS DE } \\
\text { LAVAGEM DA ETA BURU QUE } \\
\text { PERTENCE AO MUNICIPIO }\end{array}$ \\
\hline $\begin{array}{l}\text { PREFEITURA } \\
\text { MUNICIPALDE } \\
\text { JUMIRIM }\end{array}$ & $\begin{array}{l}\text { PREFEITURA } \\
\text { MUNICIPAL }\end{array}$ & Emexecução & - & $112.552,02$ & $2.284,21$ & $114.836,23$ & Município & Não reemb. & $\begin{array}{l}\text { Coleta e } \\
\text { Tratamento de } \\
\text { Esgotos } \\
\text { (habitantes) }\end{array}$ & 2798 & $\mathrm{PDC}_{3}$ & 4 & $\begin{array}{c}\text { O OBJETIVO DESSE TERMO DE } \\
\text { REFERêNCIA é A DAR DRRETRIZES } \\
\text { PARA CONTRATAção DE SERVIçOS } \\
\text { PROFISSIONAIS E }\end{array}$ \\
\hline $\begin{array}{c}\text { SERVIÇO } \\
\text { AUTOONOMO } \\
\text { MUNICIPALDE } \\
\text { ÁGUA EESGOTO DE }\end{array}$ & $\begin{array}{l}\text { SANEAMENTO } \\
\text { PÚBLICO }\end{array}$ & Cancelado & $30 / 04 / 2014$ & $73.188,00$ & $8.132,00$ & $81.320,00$ & Município & Não reemb. & $\begin{array}{l}\text { Abastecimento de } \\
\text { Água (habitantes) }\end{array}$ & 36835 & $\mathrm{PDC}_{3}$ & 6 & $\begin{array}{l}\text { O MUNICIPIO DE TIETê NãO POSSUI } \\
\text { CADASTRO DO SISTEMA DE } \\
\text { ESGOTAMENTO SANITáRIO (POçOS DE } \\
\text { VISITAS, REDE }\end{array}$ \\
\hline
\end{tabular}




\begin{tabular}{|c|c|c|c|c|c|c|c|c|c|c|c|c|c|}
\hline Nome do interessado & $\begin{array}{l}\text { Atividade principal do } \\
\text { interessado }\end{array}$ & $\begin{array}{c}\text { Situação do } \\
\text { empreendimento }\end{array}$ & $\begin{array}{l}\text { Data de } \\
\text { conclusão }\end{array}$ & Valor aprovado & $\begin{array}{c}\text { Valor de } \\
\text { contrapartida }\end{array}$ & Valor total & $\begin{array}{l}\text { Segmento do } \\
\text { interessado }\end{array}$ & Modalidade & $\begin{array}{l}\text { Benefício: } \\
\text { indicador }\end{array}$ & $\begin{array}{c}\text { População } \\
\text { beneficiada }\end{array}$ & PDC: sigla & $\begin{array}{l}\text { Tempo de } \\
\text { execuşão } \\
\text { (meses) }\end{array}$ & Descrição \\
\hline $\begin{array}{l}\text { PREFEITURA } \\
\text { MUNICIPALDE } \\
\text { CERQUILHO }\end{array}$ & $\begin{array}{l}\text { PREFEITURA } \\
\text { MUNICIPAL }\end{array}$ & Emexecução & - & $125.951,00$ & $4.081,75$ & $130.032,75$ & Município & Não reemb. & Outros (contratos) & 39617 & $\mathrm{PDCO3}$ & 6 & $\begin{array}{l}\text { O OBJETIVO DO PRESENTE TERMO DE } \\
\text { REFERêNCIA é A CONTRATAç̃o DE } \\
\text { EMPRESA DE CONSULTORIA E } \\
\text { ENGENHARIA PA }\end{array}$ \\
\hline $\begin{array}{l}\text { PREFEITURA } \\
\text { MUNICIPAL DE } \\
\text { PEREIRAS }\end{array}$ & $\begin{array}{l}\text { PREFEITURA } \\
\text { MUNICIPAL }\end{array}$ & Emexecução & - & $74.773,07$ & $8.577,92$ & $83.350,99$ & Município & Não reemb. & $\begin{array}{l}\text { Estudos/Projetos } \\
\text { (contratos) }\end{array}$ & 23742 & $\mathrm{PDC0} 3$ & 6 & $\begin{array}{l}\text { AVALIAR OS IMPACTOS AMBIENTAIS } \\
\text { CAUSADOS NA áREA DO RIBEIRãO } \\
\text { DAS CONCHAS NO MUNICIPIO DE } \\
\text { PEREIRAS, NO }\end{array}$ \\
\hline $\begin{array}{l}\text { PREFEITURA } \\
\text { MUNICIPALDE } \\
\text { QUADRA }\end{array}$ & $\begin{array}{l}\text { PREFEITURA } \\
\text { MUNICIPAL }\end{array}$ & Emexecução & - & $206.928,00$ & $4.130,40$ & $211.058,40$ & Município & Não reemb. & $\begin{array}{l}\text { Coleta e } \\
\text { Tratamento de } \\
\text { Esgotos } \\
\text { (habitantes) }\end{array}$ & 320 & $\mathrm{PDC0} 3$ & 6 & $\begin{array}{l}\text { REDUZIR A COTAMINAÇ̃̃O DE } \\
\text { MANANCIAIS SUBTERRANEOS E } \\
\text { SUPERFICAIIS POR ESGOOTO } \\
\text { DOMÉSTICO, CONSTRUINDO } 80\end{array}$ \\
\hline $\begin{array}{l}\text { CONSÓRCIO DE } \\
\text { ESTUDOS, } \\
\text { RECUPERAÇÃO E } \\
\text { DESENVOLVIMENTO } \\
\text { DA BACIA DOS RIOS }\end{array}$ & $\begin{array}{c}\text { CONSÓRCIO } \\
\text { INTERMUNICIPAL }\end{array}$ & Cancelado & 16/03/2016 & $175.411,08$ & $9.704,79$ & $185.115,87$ & Sociedade Civil & Não reemb. & $\begin{array}{l}\text { Estudos/Projetos } \\
\text { (contratos) }\end{array}$ & 500000 & PDC01 & 8 & $\begin{array}{l}\text { O RIO SARAPUíe, JUNTAMENTE COM } \\
\text { O RIO SOROCABA, MANANCIAL DE } \\
\text { ABASTECIMENTO PúBLICO DA BACIA } \\
\text { DO SMT. }\end{array}$ \\
\hline $\begin{array}{l}\text { PREFEITURA } \\
\text { MUNICIPALDE } \\
\text { MAIRINQUE }\end{array}$ & $\begin{array}{l}\text { PREFEITURA } \\
\text { MUNICIPAL }\end{array}$ & Emexecução & - & $78.231,00$ & $1.599,50$ & $79.830,50$ & Município & Não reemb. & $\begin{array}{l}\text { Estudos/Projetos } \\
\text { (contratos) }\end{array}$ & 45223 & PDC05 & 12 & $\begin{array}{c}\text { MAPEAR E DIAGNOSTICAR A } \\
\text { SITUAçãO ATUAL DAS ÁREAS DE } \\
\text { PRESERVAç̃o PERMANENTE (APPS), } \\
\text { COMO SUBSIDIO AO }\end{array}$ \\
\hline $\begin{array}{l}\text { PREFEITURA } \\
\text { MUNICIPALDE } \\
\text { LARANJAL } \\
\text { PAULISTA }\end{array}$ & $\begin{array}{l}\text { PREFEITURA } \\
\text { MUNICIPAL }\end{array}$ & Cancelado & 04/01/2017 & $349.442,01$ & $7.131,47$ & $356.573,48$ & Município & Não reemb. & $\begin{array}{l}\text { Recomposição de } \\
\text { Mata Ciliar } \\
\text { (hectares) }\end{array}$ & 27000 & PDC09 & 24 & $\begin{array}{l}\text { PRESERVAR OS CURSOS D'AGUA E } \\
\text { AUMENTAR A QUANTIDADE DE } \\
\text { MATA NO MUNICIIIO QUE } \\
\text { ATUALMENTE TEM APROXIMAD }\end{array}$ \\
\hline $\begin{array}{l}\text { PREFEITURA } \\
\text { MUNICIPALDE } \\
\text { ARAÇOIABA DA } \\
\text { SERRA }\end{array}$ & $\begin{array}{l}\text { PREFEITURA } \\
\text { MUNICIPAL }\end{array}$ & Emexecução & - & $252.695,00$ & $5.157,00$ & $257.852,00$ & Município & Não reemb. & $\begin{array}{l}\text { Estudos/Projetos } \\
\text { (contratos) }\end{array}$ & 27299 & PDC01 & 10 & $\begin{array}{l}\text { A ELABORAçãO DE UM ZONEAMENTO } \\
\text { GEOAMBENTAL PERMITE GERAR } \\
\text { DADOS QUE AUXILIE NO MELHOR } \\
\text { PLANEJAMENTO TE }\end{array}$ \\
\hline $\begin{array}{c}\text { SOS } \\
\text { ITUPARARANGA - } \\
\text { ORGANIZAÇÃO DA } \\
\text { SOCIEDADECIVIL DE } \\
\text { INTERESSE PÚBLICO }\end{array}$ & $\begin{array}{l}\text { PROTEÇÃO DOS } \\
\text { RECRSOS } \\
\text { HÍDRICOS E } \\
\text { PROJETOS DE } \\
\text { EDUCAÇÃO } \\
\text { AMBIENTAL }\end{array}$ & Cancelado & 04/01/2017 & $298.662,96$ & $34.231,00$ & $332.893,96$ & Sociedade Civil & Não reemb. & $\begin{array}{l}\text { Estudos/Projetos } \\
\text { (contratos) }\end{array}$ & 1000 & PDC01 & 10 & $\begin{array}{l}\text { O OBJETIVO DESTE PROJETO é } \\
\text { DIAGNOSTICAR PARA DEFINIR AS } \\
\text { METODOLOGIAS DE RESTAURAçãO E } \\
\text { REALIZAR UM CA }\end{array}$ \\
\hline $\begin{array}{l}\text { SOS } \\
\text { ITUPARARANGA - } \\
\text { ORGANIZAÇÃO DA } \\
\text { SOCIEDADECIVIL DE } \\
\text { INTERESSE PÚBLICO }\end{array}$ & $\begin{array}{l}\text { PROTEÇÃO DOS } \\
\text { RECURSOS } \\
\text { HÉDRICOS E } \\
\text { PROETESOS DE } \\
\text { EDUCAÇ̃̃O } \\
\text { AMBIENTAL }\end{array}$ & Emexecução & - & $390.822,96$ & $50.030,08$ & $440.853,04$ & Sociedade Civil & Não reemb. & $\begin{array}{l}\text { Educação } \\
\text { Ambiental } \\
\text { (contratos) }\end{array}$ & 2000 & $\mathrm{PDCO}_{3}$ & 7 & $\begin{array}{l}\text { CONTRIBUIR COM A MELHORIA DA } \\
\text { QUALIDADE DOS RECURSOS HDRICOS } \\
\text { DA MICROBACIA DO SOROCAMIRIM, } \\
\text { EM ESPECI }\end{array}$ \\
\hline $\begin{array}{l}\text { SOS } \\
\text { ITUPARARANGA - } \\
\text { ORGANIZACCÃO DA } \\
\text { SOCIEDADECIVIL DE } \\
\text { INTERESSE PÚBLICO }\end{array}$ & $\begin{array}{l}\text { PROTEÇÃO DOS } \\
\text { RECURSOS } \\
\text { HÍDRICOS E } \\
\text { PROJETOS DE } \\
\text { EDUCAÇÃO } \\
\text { AMBIENTAL }\end{array}$ & Cancelado & $30 / 04 / 2014$ & 0 & 0 & 0 & Sociedade Civil & Não reemb. & $\begin{array}{l}\text { Recomposiç̃̃o de } \\
\text { Mata Ciliar } \\
\text { (hectares) }\end{array}$ & 8 & PDC05 & 33 & $\begin{array}{l}\text { O OBJETIVO GERAL DO PROJETO é } \\
\text { REALZZAR A ADEQUAçãO } \\
\text { AMBIENTALDAS PROPRIEDADES } \\
\text { LOCALIZADAS NO BAIRRO }\end{array}$ \\
\hline \begin{tabular}{l}
\multicolumn{1}{c}{ SOS } \\
ITUPARARANGA - \\
ORGANIZAÇ̃̃O DA \\
SOCIEDADECIVIL DE \\
INTERESSE PÚBLICO
\end{tabular} & $\begin{array}{l}\text { PROTEÇÃO DOS } \\
\text { RECURSOS } \\
\text { HÍDRICOS E } \\
\text { PROJETOS DE } \\
\text { EDUCAÇÃO } \\
\text { AMBIENTAL }\end{array}$ & Emexecução & - & $244.968,40$ & $28.929,00$ & $273.897,40$ & Sociedade Civil & Não reemb. & $\begin{array}{l}\text { Estudos/Projetos } \\
\text { (contratos) }\end{array}$ & 2000 & PDC01 & 12 & $\begin{array}{l}\text { O OBJETIVO GERAL DO PROJETOé } \\
\text { REVELAR OS DADOS REAIS DE } \\
\text { CAPTAçãO DE DáGUAS ELANçAMENTO } \\
\text { DE EFLUENTES }\end{array}$ \\
\hline $\begin{array}{l}\text { PREFEITURA } \\
\text { MUNICIPALDE } \\
\text { IPERÓ }\end{array}$ & $\begin{array}{l}\text { PREFEITURA } \\
\text { MUNICIPAL }\end{array}$ & Cancelado & $30 / 04 / 2014$ & 0 & 0 & 0 & Município & Não reemb. & $\begin{array}{l}\text { Coleta e } \\
\text { Tratamento de } \\
\text { Esgotos } \\
\text { (habitantes) }\end{array}$ & 2007 & $\mathrm{PDCO}$ & 4 & $\begin{array}{c}\text { A IMPLANTAç̃o DO } \\
\text { EMPREENDIMENTO TEM COMO } \\
\text { OBJETIVO MELHORAR A SAúDE } \\
\text { PúBLICA DA COMUNIDADE, } \\
\text { INCLUINDO }\end{array}$ \\
\hline $\begin{array}{l}\text { PREFEITURA } \\
\text { MUNICIPAL DE } \\
\text { IPERÓ }\end{array}$ & $\begin{array}{l}\text { PREFEITURA } \\
\text { MUNICIPAL }\end{array}$ & Cancelado & $30 / 04 / 2014$ & 0 & 0 & 0 & Município & Não reemb. & $\begin{array}{l}\text { Coleta e } \\
\text { Tratamento de } \\
\text { Esgotos } \\
\text { (habitantes) }\end{array}$ & 1320 & $\mathrm{PDCO}_{3}$ & 4 & $\begin{array}{c}\text { A IMPLANTAção DE SISTEMA DE } \\
\text { ESGOTAMENTO SANITáRIO VISA A } \\
\text { PRESERVAçãOO DA QUALIDADE DA } \\
\text { áGUA NA BACIA H }\end{array}$ \\
\hline
\end{tabular}




\begin{tabular}{|c|c|c|c|c|c|c|c|c|c|c|c|c|c|}
\hline Nome do interessado & $\begin{array}{l}\text { Atividade principal do } \\
\text { interessado }\end{array}$ & $\begin{array}{c}\text { Situação do } \\
\text { empreendimento }\end{array}$ & $\begin{array}{c}\text { Data de } \\
\text { conclusão }\end{array}$ & Valor aprovado & $\begin{array}{c}\text { Valor de } \\
\text { contrapartida }\end{array}$ & Valor total & $\begin{array}{l}\text { Segmento do } \\
\text { interessado }\end{array}$ & Modalidade & $\begin{array}{l}\text { Benefício: } \\
\text { indicador }\end{array}$ & $\begin{array}{l}\text { População } \\
\text { beneficiadada }\end{array}$ & PDC: sigla & $\begin{array}{l}\text { Tempo de } \\
\text { execução } \\
\text { (meses) }\end{array}$ & Descrição \\
\hline $\begin{array}{c}\text { SERVIÇO } \\
\text { AUTÔNOMO } \\
\text { MUNICIPAL DE } \\
\text { ÁGUA EESGOTO DE } \\
\text { TIETÊ-SAMAE }\end{array}$ & $\begin{array}{l}\text { SANEAMENTO } \\
\text { PÚBLICO }\end{array}$ & Cancelado & 30/04/2014 & $119.172,00$ & $29.793,00$ & $148.965,00$ & Município & Não reemb. & $\begin{array}{c}\text { Coleta e } \\
\text { Tratamento de } \\
\text { Esgotos } \\
\text { (habitantes) }\end{array}$ & 36835 & $\mathrm{PDC}_{3}$ & 6 & $\begin{array}{l}\text { O OBJETIVO PRINCIPAL DO PRESENTE } \\
\text { TRABALHO CONSISTE NA } \\
\text { ELABORAçã̃ DE PROJETO EXECUTIVO } \\
\text { DO EMISŚRIIO D }\end{array}$ \\
\hline $\begin{array}{l}\text { FATEC TATUÚ- } \\
\text { PROFESSOR WILSON } \\
\text { ROBERTO RIBEIRO } \\
\text { DE CAMARGO }\end{array}$ & $\begin{array}{l}\text { INSTITUIçãO DE } \\
\text { ENSINO }\end{array}$ & Cancelado & 16/03/2016 & $277.404,92$ & $40.472,40$ & $317.877,32$ & Estado & Não reemb. & Outros (contratos) & 41901219 & $\mathrm{PDC} 03$ & 6 & $\begin{array}{l}\text { ESTE PROJETO TEM COMO OBJETIVO } \\
\text { VIABIIZARAR AMPLANTAçãO DE } \\
\text { INFRAESTRUTURA PARA O } \\
\text { PROCESSAMENTO DECA }\end{array}$ \\
\hline $\begin{array}{l}\text { PREFEITURA } \\
\text { MUNICIPAL DA }\end{array}$ & $\begin{array}{l}\text { PREFEITURA } \\
\text { MUNICIPAL }\end{array}$ & Cancelado & 16/03/2016 & $399.648,77$ & $185.988,56$ & $585.637,33$ & Município & Não reemb. & $\begin{array}{l}\text { Recomposição de } \\
\text { Mata Ciliar }\end{array}$ & 50000 & PDC09 & 16 & $\begin{array}{l}\text { POSSIBILITAR QUE NO ESPAçO DE } \\
\text { PRODUÇãO DE MUDAS, ALÉM DE }\end{array}$ \\
\hline $\begin{array}{l}\text { FUNDAÇÃO PARA A } \\
\text { CONSERVAÇÃOE A }\end{array}$ & $\begin{array}{l}\text { CONSERVAÇ̃̃̃O, } \\
\text { PRODUÇAÕ E }\end{array}$ & Em execução & & $292.850,00$ & $32.736,00$ & $325.586,00$ & Estado & Não reemb. & $\begin{array}{l}\text { Estudos/Projetos } \\
\text { (contratos) }\end{array}$ & 39628 & PDC01 & 12 & $\begin{array}{l}\text { O OBJETIVO DO PRESENTE PROJETO é } \\
\text { ELABORAR O PLANO DE MANEJO DA } \\
\text { ELABORAR PROJETO DE UMA }\end{array}$ \\
\hline $\begin{array}{l}\text { PREFEITURA DO } \\
\text { MUNICIPIO DE TIETÊ }\end{array}$ & $\begin{array}{l}\text { ADMINISTRAÇ̃̃O } \\
\text { MUNICIPAL }\end{array}$ & Cancelado & 30/04/2014 & 0 & 0 & 0 & Município & Não reemb. & $\begin{array}{c}\text { Estudos/Projetos } \\
\text { (contratos) }\end{array}$ & 36827 & $\mathrm{PDC} 03$ & 6 & $\begin{array}{l}\text { ESTAÇão DE TRATAMENTO DE } \\
\text { ESGOTO (ETE) PARA O PARQUE } \\
\text { ECOLÓGGCO CORNéLIO PIRES }\end{array}$ \\
\hline $\begin{array}{l}\text { PREFEITURA } \\
\text { MUNICIPAL DA } \\
\text { ESTÂNCIA } \\
\text { TURÍSTICA DE } \\
\text { IBIUUNA }\end{array}$ & $\begin{array}{l}\text { PREFEITURA } \\
\text { MUNICIPAL }\end{array}$ & Emexecução & & $189.385,86$ & $12.400,00$ & $201.785,86$ & Município & Não reemb. & $\begin{array}{l}\text { Estudos/Projetos } \\
\text { (contratos) }\end{array}$ & 500 & PDC09 & 18 & $\begin{array}{l}\text { POR SER UM PROJETO QUE VISA A } \\
\text { CONERVAçãO E PROTEÇãO DE } \\
\text { MANANCAIIS SUPERFICIAIS DE } \\
\text { ABASTECIMENTO URB }\end{array}$ \\
\hline $\begin{array}{l}\text { PREFEITURA DO } \\
\text { MUNICIPIO DE TIETÊ }\end{array}$ & $\begin{array}{l}\text { ADMINISTRAÇÃO } \\
\text { MUNICIPAL }\end{array}$ & Em execução & - & $394.819,21$ & $34.703,62$ & $429.522,83$ & Município & Não reemb. & $\begin{array}{l}\text { Estudos/Projetos } \\
\text { (contratos) }\end{array}$ & 36835 & $\mathrm{PDC} 03$ & 6 & $\begin{array}{l}\text { CONFORME Já DESCRITO, EXISTEM } 4 \\
\text { áREAS NO MUNICIPIO DE TIETê QUE } \\
\text { NECESSITAM DE UMA AVALIA̧̧ão } \\
\text { PRELIMIN }\end{array}$ \\
\hline $\begin{array}{c}\text { AGÊNCIA } \\
\text { REGULADORA DE } \\
\text { SERVICCOS } \\
\text { DELEGADOS DO } \\
\text { MUNIĆ́IIO DA } \\
\text { ESTÂNCIA } \\
\text { TURÍSTICA DE ITU - } \\
\text { AR-ITU }\end{array}$ & $\begin{array}{l}\text { SANEAMENTO } \\
\text { BÁSICO }\end{array}$ & Emexecução & & $207.864,87$ & $28.687,97$ & $236.552,84$ & Município & Não reemb. & $\begin{array}{l}\text { Estudos/Projetos } \\
\text { (contratos) }\end{array}$ & 156000 & PDC01 & 12 & $\begin{array}{c}\text { O OBJETIVO DESTE ESTUDO E A } \\
\text { ELABORAÇÃO DE UM BANCO DE } \\
\text { DADOS GEORREFERENCIADO QUE } \\
\text { POSSIBILITEA GESTA }\end{array}$ \\
\hline $\begin{array}{l}\text { PREFEITURA } \\
\text { MUNICIPAL DE } \\
\text { JUMIRIM }\end{array}$ & $\begin{array}{l}\text { PREFEITURA } \\
\text { MUNICIPAL }\end{array}$ & Cancelado & 03/06/2015 & 0 & 0 & 0 & Município & Não reemb. & $\begin{array}{l}\text { Coleta e } \\
\text { Tratamento de } \\
\text { Esgotos } \\
\text { (habitantes) }\end{array}$ & 2978 & $\mathrm{PDCO}_{3}$ & 6 & $\begin{array}{l}\text { JUSTIFICA-SE COMO TOMADORA DO } \\
\text { EMPREENDIMENTO, UMA VEZ QUE, A } \\
\text { PREFEITURA MUNICIPAL NãO DISPõE } \\
\text { DE EQUI }\end{array}$ \\
\hline $\begin{array}{l}\text { PREFEITURA } \\
\text { MUNICIPALDE } \\
\text { PORTO FELIZ }\end{array}$ & $\begin{array}{l}\text { PREFEITURA } \\
\text { MUNICIPAL }\end{array}$ & Cancelado & 03/06/2015 & 0 & 0 & 0 & Município & Não reemb. & $\begin{array}{l}\text { Estudos/Projetos } \\
\quad \text { (contratos) }\end{array}$ & 51320 & $\mathrm{PDCO}_{3}$ & 12 & $\begin{array}{c}\text { O OBJETIVO DO PRESENTE TRABALHO } \\
\text { ÉBUSCAR ATRA VÉS DO FEHIDRO O } \\
\text { FINANCIAMENTO PARA A } \\
\text { CONTRATAÇÃO DE EM }\end{array}$ \\
\hline $\begin{array}{l}\text { PREFEITURA } \\
\text { MUNICIPAL DE } \\
\text { SOROCABA }\end{array}$ & PREFEITURA & Cancelado & 03/06/2015 & 0 & 0 & 0 & Sociedade Civil & Não reemb. & $\begin{array}{l}\text { Estudos/Projetos } \\
\text { (contratos) }\end{array}$ & 600000 & PDC05 & 8 & $\begin{array}{l}\text { CADASTRO DAS NASCENTES. } \\
\text { DIAGNóSTICO AMBIENTAL. }\end{array}$ \\
\hline $\begin{array}{l}\text { PREFEITURA } \\
\text { MUNICIPALDE } \\
\text { MAIRINQUE }\end{array}$ & $\begin{array}{l}\text { PREFEITURA } \\
\text { MUNICIPAL }\end{array}$ & Cancelado & 04/01/2017 & $78.490,00$ & $1.449,50$ & $79.939,50$ & Município & Não reemb. & $\begin{array}{l}\text { Estudos/Projetos } \\
\text { (contratos) }\end{array}$ & 45223 & PDC01 & 12 & $\begin{array}{l}\text { OFRAGMENTO FLORESTAL INSERIDO } \\
\text { NA áREA URBANA DO MUNICIPIO DE } \\
\text { MAIRINQUE/SP, DENOMINADO } \\
\text { PARQUEMUNICI }\end{array}$ \\
\hline $\begin{array}{c}\text { SERVIÇO } \\
\text { AUTÔNOMO } \\
\text { MUNICIPAL DE } \\
\text { ÁGUA EESGOTO DE } \\
\text { TIETÊ- SAMAE }\end{array}$ & $\begin{array}{l}\text { SANEAMENTO } \\
\text { PÚBLICO }\end{array}$ & Cancelado & 03/06/2015 & 0 & 0 & 0 & Município & Não reemb. & $\begin{array}{c}\text { Canalização } \\
\text { (metros lineares) }\end{array}$ & 36835 & PDC01 & 6 & $\begin{array}{c}\text { O OBJETIVO DO PRESENTE TRABALHO } \\
\text { é IMPLANTAR A MODELAGEM DE } \\
\text { SIMULAč̃O COM O MODELO } \\
\text { MATEMáTICO PARA AD }\end{array}$ \\
\hline $\begin{array}{l}\text { PREFEITURA } \\
\text { MUNICIPALDE } \\
\text { MAIRINQUE }\end{array}$ & $\begin{array}{l}\text { PREFEITURA } \\
\text { MUNICIPAL }\end{array}$ & Cancelado & 04/01/2017 & $78.050,88$ & $1.672,18$ & $79.723,06$ & Município & Não reemb. & $\begin{array}{l}\text { Planej. e Gerenc. } \\
\text { dos Recs. Hídricos } \\
\text { (contratos) }\end{array}$ & 45223 & PDC01 & 12 & $\begin{array}{c}\text { O MUNICIPIO DE MAIRINQUE POSSUI } \\
\text { 5132,22 HECTARES DE SEU TERRIT6́RIO } \\
\text { DENTRO DA ÁREA DE PROTEção } \\
\text { AMIENT }\end{array}$ \\
\hline $\begin{array}{c}\text { SOS } \\
\text { ITUPARARANGA - } \\
\text { ORGANIZAÇ̃̃O DA } \\
\text { SOCIEDADE CIVIL DE } \\
\text { INTERESSE PÚBLICO }\end{array}$ & $\begin{array}{l}\text { PROTEÇÃO DOS } \\
\text { RECURSOS } \\
\text { HÍDRICOS E } \\
\text { PROJETOS DE } \\
\text { EDUCAÇÃO }\end{array}$ & Cancelado & 03/06/2015 & 0 & 0 & 0 & Sociedade Civil & Não reemb. & $\begin{array}{l}\text { Educação } \\
\text { Ambiental } \\
\text { (contratos) }\end{array}$ & 50000 & PDC01 & 12 & $\begin{array}{c}\text { OBJETIVO: O OBJETIVO PRINCIPAL DO } \\
\text { PROJETO ́́ MINIMIZAR OS IMPACTOS } \\
\text { AMBIENTAIS IDENTIFICADOS NO } \\
\text { RESERV }\end{array}$ \\
\hline $\begin{array}{l}\text { SOS } \\
\text { ITUPARARANGA - } \\
\text { ORGANIZACC̃̃O DA } \\
\text { SOCIEDADECIVIL DE } \\
\text { INTERESSE PÚBLICO }\end{array}$ & $\begin{array}{l}\text { PROTEÇ̃̃O DOS } \\
\text { RECURSOS } \\
\text { HÍDRICOS E } \\
\text { PROJETOS DE } \\
\text { EDUCACCÃO } \\
\text { AMBIENTAL }\end{array}$ & Cancelado & 03/06/2015 & 0 & 0 & 0 & Sociedade Civil & Não reemb. & $\begin{array}{l}\text { Educação } \\
\text { Ambiental } \\
\text { (contratos) }\end{array}$ & 15091 & PDC01 & 18 & $\begin{array}{l}\text { OBJETIVO: O PROJETO TEM COMO } \\
\text { OBJETIVO CRIAR NOVAS } \\
\text { FERRAMENTAS PARA INFRMAąãa, } \\
\text { FORMAção E SENSIBLIZZ }\end{array}$ \\
\hline
\end{tabular}




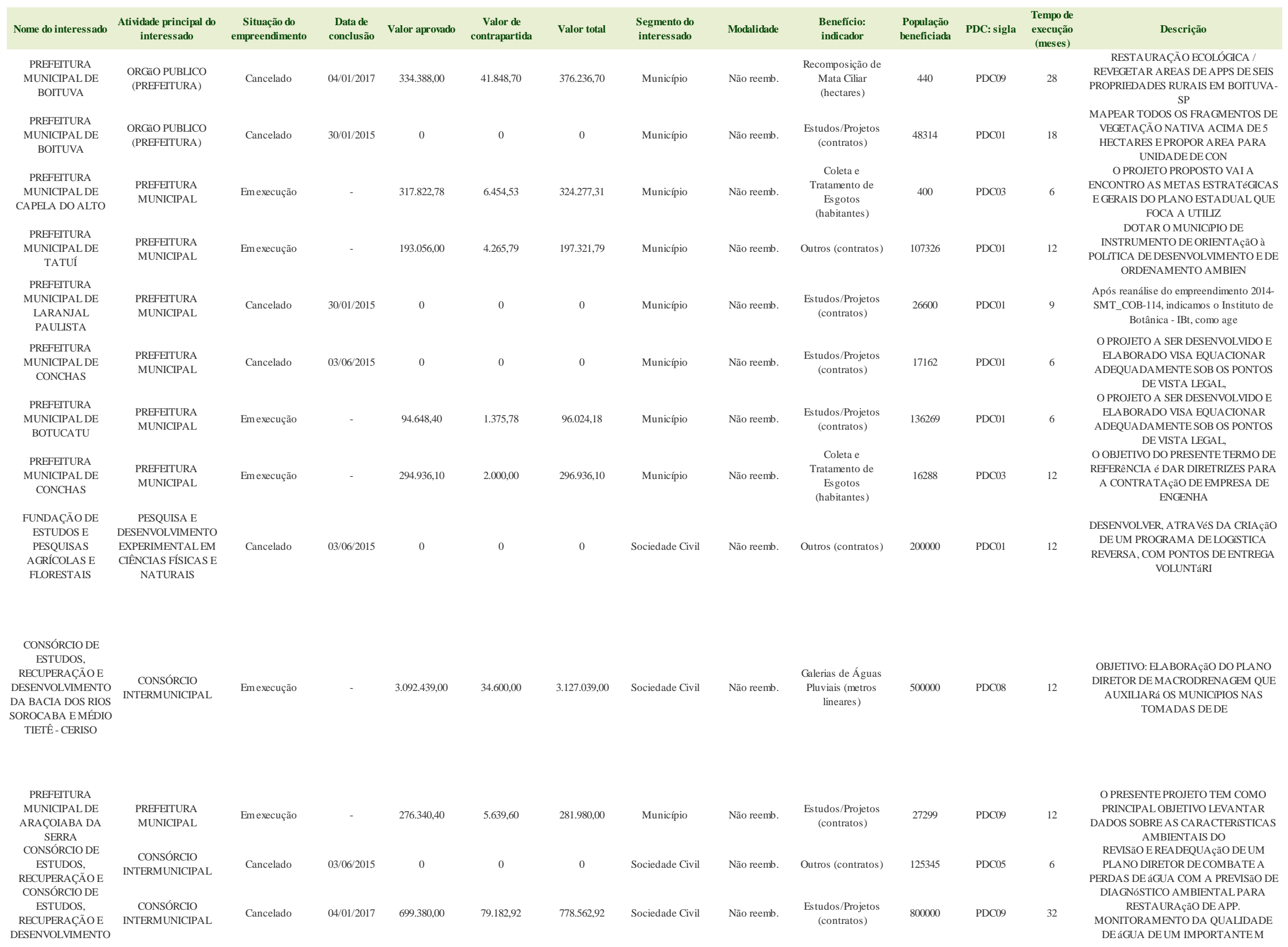




\begin{tabular}{|c|c|c|c|c|c|c|c|c|c|c|c|c|c|}
\hline Nome do interessado & $\begin{array}{l}\text { Atividade principal do } \\
\text { interessado }\end{array}$ & $\begin{array}{l}\text { Situação do } \\
\text { empreendimento }\end{array}$ & $\begin{array}{l}\text { Data de } \\
\text { conclusão }\end{array}$ & Valor aprovado & $\begin{array}{c}\text { Valor de } \\
\text { contrapartida }\end{array}$ & Valor total & $\begin{array}{l}\text { Segmento do } \\
\text { interessado }\end{array}$ & Modalidade & $\begin{array}{l}\text { Benefício: } \\
\text { indicador }\end{array}$ & $\begin{array}{l}\text { População } \\
\text { beneficiada }\end{array}$ & PDC: sigla & $\begin{array}{l}\text { Tempo de } \\
\text { execução } \\
\text { (meses) }\end{array}$ & Descrição \\
\hline $\begin{array}{c}\text { PREFEITURA } \\
\text { MUNICIPAL DE } \\
\text { VOTORANTIM }\end{array}$ & $\begin{array}{l}\text { PREFEITURA } \\
\text { MUNICIPAL }\end{array}$ & Cancelado & 04/01/2017 & $149.696,98$ & $59.582,70$ & $209.279,68$ & Município & Não reemb. & $\begin{array}{l}\text { Recomposicĩão de } \\
\text { Mata Ciliar } \\
\text { (hectares) }\end{array}$ & 1000000 & PDC01 & 24 & $\begin{array}{l}\text { INCREMENTAR A CONEXãO DOS } \\
\text { CORREDORES ECOLGGGCOS JUNTO às } \\
\text { DEMAIS RESERVAS FLORESTAIS, } \\
\text { CONTRIBUINDO PA }\end{array}$ \\
\hline $\begin{array}{l}\text { PREFEITURA } \\
\text { MUNICIPALDE } \\
\text { PIEDADE }\end{array}$ & $\begin{array}{l}\text { PREFEITURA } \\
\text { MUNICIPAL }\end{array}$ & Cancelado & 30/01/2015 & 0 & 0 & 0 & Município & Reembolsável & $\begin{array}{l}\text { Estudos/Projetos } \\
\quad \text { (contratos) }\end{array}$ & 52214 & PDC01 & 24 & $\begin{array}{l}\text { A PARTIR DO LEVANTAMENTO E } \\
\text { MAPEAMENTO ESPERA-SE OBTER AS } \\
\text { MEDIDAS DE DAP, ESPÉCIES } \\
\text { PREDOMINANTES EOS }\end{array}$ \\
\hline $\begin{array}{l}\text { PREFEITURA } \\
\text { MUNICIPALDE } \\
\text { ARAÇOIABA DA } \\
\text { SERRA }\end{array}$ & $\begin{array}{l}\text { PREFEITURA } \\
\text { MUNICIPAL }\end{array}$ & Emexecução & - & $175.224,00$ & $3.576,00$ & $178.800,00$ & Município & Não reemb. & $\begin{array}{l}\text { Estudos/Projetos } \\
\quad \text { (contratos) }\end{array}$ & 28804 & $\mathrm{PDC} 03$ & 8 & $\begin{array}{c}\text { ELABORAção DE ESTUDO DE PASSIVO } \\
\text { AMBIENTALCARACTERIZANDO A } \\
\text { PRESENçA DE CONTAMINAção NA } \\
\text { aGGA SUBTERRâ }\end{array}$ \\
\hline $\begin{array}{c}\text { SERVIÇO } \\
\text { AUTÔNOMO } \\
\text { MUNICIPALDE } \\
\text { ÁGUA EESGOTO DE } \\
\text { TIETÊ-SAMAE }\end{array}$ & $\begin{array}{l}\text { SANEAMENTO } \\
\text { PÚBLICO }\end{array}$ & Cancelado & 03/06/2015 & 0 & 0 & 0 & Município & Não reemb. & $\begin{array}{l}\text { Estudos/Projetos } \\
\text { (contratos) }\end{array}$ & 6000 & $\mathrm{PDC} 03$ & 5 & $\begin{array}{c}\text { O OBJETIVO DO PRESENTE } \\
\text { EMPREENDIMENTO CONSISTE NA } \\
\text { ELABORAçãO DE TRêS (03) PROJETOS } \\
\text { EXECUTIVOS DE EST }\end{array}$ \\
\hline $\begin{array}{c}\text { SERVIÇO } \\
\text { AUTOONOMO DE } \\
\text { ÁGUA EESGOTO DE } \\
\text { PORTO FELIZ (SAAE) }\end{array}$ & $\begin{array}{l}\text { PREFEITURA } \\
\text { MUNICIPAL }\end{array}$ & Cancelado & 03/06/2015 & 0 & 0 & 0 & Município & Não reemb. & Outros (contratos) & 43136 & $\mathrm{PDC}_{3}$ & 6 & $\begin{array}{l}\text { JUSTIFICATIVA: O PROJETO DE } \\
\text { RECUPERAçãO EREUSO DA áGUA DE } \\
\text { LAVAGEM, DISPOSIçAO FINAL DO } \\
\text { LODO E ADEQU }\end{array}$ \\
\hline $\begin{array}{c}\text { SERVICO } \\
\text { AUTONOMO DE } \\
\text { AGUA, ESGOTO E } \\
\text { MEIO AMBIENTE- } \\
\text { SAAE AMBIENTAL }\end{array}$ & $\begin{array}{l}\text { SETOR DE } \\
\text { SANEAMENTO } \\
\text { BáSICO }\end{array}$ & Cancelado & 03/06/2015 & 0 & 0 & 0 & Município & Não reemb. & $\begin{array}{l}\text { Estudos/Projetos } \\
\quad \text { (contratos) }\end{array}$ & 105569 & PDC01 & 12 & $\begin{array}{c}\text { OBTENÇÃO DE UM BANCO DE DADOS } \\
\text { GEORREFERENCIADO DA BACIA } \\
\text { HIDROGRAFICA DO RIBEIRAO BURU, } \\
\text { INCLUINDO A S }\end{array}$ \\
\hline $\begin{array}{c}\text { SERVICCO } \\
\text { AUTÔNOMO } \\
\text { MUNICIPALDE } \\
\text { ÁGUA EESGOTO DE } \\
\text { TIETÊ- - SAMAE }\end{array}$ & $\begin{array}{l}\text { SANEAMENTO } \\
\text { PÚBLICO }\end{array}$ & Em execução & - & $73.188,00$ & $8.100,00$ & $81.288,00$ & Município & Não reemb. & $\begin{array}{l}\text { Estudos/Projetos } \\
\quad \text { (contratos) }\end{array}$ & 36835 & $\mathrm{PDC} 03$ & 6 & $\begin{array}{l}\text { O MUNICIPIO DE TIETê NãO POSSUI O } \\
\text { CADASTRO DAS REDES DE } \\
\text { ESGOTAMENTO SANITáRIO, (POÇOS DE } \\
\text { VISITAS, RE }\end{array}$ \\
\hline $\begin{array}{c}\text { SERVIÇO } \\
\text { AUTÔNOMO } \\
\text { MUNICIPALDE } \\
\text { ÁGUA EESGOTO DE } \\
\text { TIETÊ- SAMAE }\end{array}$ & $\begin{array}{l}\text { SANEAMENTO } \\
\text { PÚBLICO }\end{array}$ & Cancelado & 03/06/2015 & $119.172,00$ & $29.793,00$ & $148.965,00$ & Município & Não reemb. & $\begin{array}{l}\text { Estudos/Projetos } \\
\quad \text { (contratos) }\end{array}$ & 36835 & $\mathrm{PDC}_{3}$ & 6 & $\begin{array}{l}\text { O OBJETIVO PRINCIPAL DO PRESENTE } \\
\text { TRABALHO CONSISTE NA } \\
\text { ELABORAçãO DE PROJETO EXECUTIVO } \\
\text { DO EMISSáRIO D }\end{array}$ \\
\hline $\begin{array}{l}\text { PREFEITURA } \\
\text { MUNICIPALDE } \\
\text { VOTORANTIM }\end{array}$ & $\begin{array}{l}\text { PREFEITURA } \\
\text { MUNICIPAL }\end{array}$ & Emexecução & - & $140.832,75$ & $4.846,09$ & $145.678,84$ & Município & Não reemb. & $\begin{array}{l}\text { Estudos/Projetos } \\
\quad \text { (contratos) }\end{array}$ & 40000 & PDC01 & 10 & $\begin{array}{c}\text { PASSA PELA POLITICA AMBIENTAL } \\
\text { DO MUNICIPIO Eé PAUTA } \\
\text { PRIORITáRIA NOS CRITÉRIOS GERAIS } \\
\text { PARA HIERARQUI }\end{array}$ \\
\hline $\begin{array}{l}\text { SERVIÇO } \\
\text { AUTÔNOMO DE } \\
\text { ÁGUA EESGOTO DE } \\
\text { CERQULHO }\end{array}$ & $\begin{array}{l}\text { SERVIÇO DE } \\
\text { SANEAMENTO } \\
\text { BÁSICO }\end{array}$ & Emexecução & - & $395.620,93$ & $124.164,72$ & $519.785,65$ & Municííio & Não reemb. & $\begin{array}{l}\text { Abastecimento de } \\
\text { Água (habitantes) }\end{array}$ & 39617 & PDC05 & 6 & $\begin{array}{c}\text { O OBJETO DESTE TRABALHO é A } \\
\text { CONTRATAçãO DE EMPRESA } \\
\text { ESPECIALZZADA PARA EXECUção DE } \\
\text { SERVIçOS DE ENGENH }\end{array}$ \\
\hline $\begin{array}{c}\text { SERVIÇO } \\
\text { AUTÔNOMO DE } \\
\text { ÁGUA EESGOTO DE } \\
\text { CERQUILHO } \\
\text { AGÊNCIA }\end{array}$ & $\begin{array}{l}\text { SERVIÇO DE } \\
\text { SANEAMENTO } \\
\text { BÁSICO }\end{array}$ & Em execução & - & $133.894,03$ & $14.710,10$ & $148.604,13$ & Município & Não reemb. & $\begin{array}{l}\text { Estudos/Projetos } \\
\text { (contratos) }\end{array}$ & 39617 & $\mathrm{PDC} 03$ & 6 & $\begin{array}{c}\text { O PROJETO DE RECUPERAção E REUSO } \\
\text { DAS áGUSA DE LAVAGEM IRá } \\
\text { PERMITIR A UTILIZAçãO DESSAS } \\
\text { áGUAS DE VOLT }\end{array}$ \\
\hline $\begin{array}{l}\text { REGULADORA DE } \\
\text { SERVIÇOS } \\
\text { DELEGADOS DO } \\
\text { MUNICÍPIO DA } \\
\text { ESTÂNCIA } \\
\text { TURÍSTICA DE ITU - } \\
\text { AR-ITU }\end{array}$ & $\begin{array}{l}\text { SANEAMENTO } \\
\text { BÁSICO }\end{array}$ & Emexecução & - & $185.881,36$ & $93.765,64$ & $279.647,00$ & Município & Não reemb. & $\begin{array}{l}\text { Planej. e Gerenc. } \\
\text { dos Recs. Hídricos } \\
\text { (contratos) }\end{array}$ & 156000 & PDC01 & 12 & $\begin{array}{c}\text { O OBJETIVO ENFASEÉ O DE EFETUAR } \\
\text { ESTUDO Ȧ LUZ DAS INTERFERENCIAS } \\
\text { ANTROPICAS, DE CARACTERIZAÇÃO } \\
\text { E MON }\end{array}$ \\
\hline $\begin{array}{c}\text { PREFEITURA } \\
\text { MUNICIPAL DE } \\
\text { CAPELA DO ALTO }\end{array}$ & $\begin{array}{l}\text { PREFEITURA } \\
\text { MUNICIPAL }\end{array}$ & Concluído & 24/10/2016 & $463.230,65$ & $9.432,28$ & $472.662,93$ & Município & Não reemb. & $\begin{array}{l}\text { Trat. e Disposição } \\
\text { de Lixo - Obras } \\
\text { (habitantes) }\end{array}$ & 15000 & PDC01 & 8 & $\begin{array}{l}\text { O GALPãO VISA ATENDER A } \\
\text { LEGISLAçãO FEDERAL EESTADUALE } \\
\text { ESTAR PREPARADO PARA O PLANO }\end{array}$ \\
\hline
\end{tabular}




\begin{tabular}{|c|c|c|c|c|c|c|c|c|c|c|c|c|c|}
\hline Nome do interessado & $\begin{array}{l}\text { Atividade principal do } \\
\text { interessado }\end{array}$ & $\begin{array}{c}\text { Situaç̃o do } \\
\text { empreendimento }\end{array}$ & $\begin{array}{c}\text { Data de } \\
\text { conclusão }\end{array}$ & Valor aprovado & $\begin{array}{c}\text { Valor de } \\
\text { contrapartida }\end{array}$ & Valor total & $\begin{array}{l}\text { Segmento do } \\
\text { interessado }\end{array}$ & Modalidade & $\begin{array}{l}\text { Benefício: } \\
\text { indicador }\end{array}$ & $\begin{array}{l}\text { População } \\
\text { beneficiada }\end{array}$ & PDC: sigla & $\begin{array}{c}\text { Tempo de } \\
\text { execução } \\
\text { (meses) }\end{array}$ & Descrição \\
\hline $\begin{array}{l}\text { CENTRO ESTADUAL } \\
\text { DEEDUCACC̃̃O } \\
\text { TECNOLÓGICA } \\
\text { PAULA SOUZA }\end{array}$ & EDUCAÇÃO & Em execuu̧ão & & $303.012,60$ & $83.883,40$ & $386.896,00$ & Estado & Não reemb. & Outros (contratos) & 1225145 & PDC01 & 12 & $\begin{array}{l}\text { MPLANTAR UM SISTEMA } \\
\text { AUTOḾTICO INFORMATIZADO DE } \\
\text { DADOS METEOROĹGiCOCS, COM } \\
\text { APLICAçõES E USO EM GESTão }\end{array}$ \\
\hline $\begin{array}{l}\text { FATEC TATUÚ- } \\
\text { PROFESSOR WILSON } \\
\text { ROBERTO RIBEIRO } \\
\text { DECAMARGO }\end{array}$ & $\begin{array}{l}\text { INSTITUIçã̃ DE } \\
\text { ENSINO }\end{array}$ & Cancelado & 04/01/2017 & $311.760,00$ & $80.536,00$ & $392.296,00$ & Estado & Não reemb. & $\begin{array}{l}\text { Galerias de Águas } \\
\text { Pluviais (metros } \\
\text { lineares) }\end{array}$ & 2500 & PDC05 & 12 & $\begin{array}{l}\text { ESTE PROJETO TEM COMO META } \\
\text { DESENVOLVER TECNOLOGIAS QUE } \\
\text { GEREM MELHORIAS AMBIENTAIS, } \\
\text { PROMOVENDO A SUST }\end{array}$ \\
\hline $\begin{array}{l}\text { PREFEITURA } \\
\text { MUNICIPALDE } \\
\text { LARANJAL } \\
\text { PAULISTA }\end{array}$ & $\begin{array}{l}\text { PREFEITURA } \\
\text { MUNICIPAL }\end{array}$ & Cancelado & 04/07/2016 & 0 & 0 & 0 & Município & Não reemb. & $\begin{array}{l}\text { Trat.e Disposição } \\
\text { de Lixo - Obras } \\
\text { (habitantes) }\end{array}$ & 100 & PDC01 & 16 & $\begin{array}{l}\text { TER UM CENTRO DE EDUCAçãO } \\
\text { AMBIENTAL COM ATIVIDADES } \\
\text { PERMANENTE TANTO PARA AS } \\
\text { ESCOLAS PUBLICAS COMO PA }\end{array}$ \\
\hline $\begin{array}{l}\text { SOS } \\
\text { ITUPARARANGA - } \\
\text { ORGANIZAÇÃO DA } \\
\text { SOCIEDADECILIL DE } \\
\text { INTERESSE PÚBLICO }\end{array}$ & $\begin{array}{l}\text { PROTEČ̃̃ DOS } \\
\text { RECURSOS } \\
\text { HÍDRICOS E } \\
\text { PROJETOS DE } \\
\text { EDUCAÇÃO } \\
\text { AMBIENTAL }\end{array}$ & Em execução & - & $353.125,67$ & $45.873,60$ & $398.999,27$ & Sociedade Civil & Não reemb. & $\begin{array}{l}\text { Estudos/Projetos } \\
\text { (contratos) }\end{array}$ & 15791 & PDC01 & 12 & $\begin{array}{c}\text { OBJETIVO: O PROJETO TEM COMO } \\
\text { OBJETIVO CRIAR NOVAS } \\
\text { FERRAMENTAS PARA INFORMAção, } \\
\text { FORMAçãO E SENSIBILIZ }\end{array}$ \\
\hline $\begin{array}{l}\text { CONSÓRCIO DE } \\
\text { ESTUDOS, } \\
\text { RECUPERAÇÃ̃O E } \\
\text { DESENVOLVIMENTO } \\
\text { DA BACIA DOS RIOS } \\
\text { SOROCABA EMÉDIO } \\
\text { TIETÊ- CERISO }\end{array}$ & $\begin{array}{l}\text { CONSÓRCIO } \\
\text { INTERMUNICIPAL }\end{array}$ & Não iniciado & & $312.201,60$ & 0 & $312.201,60$ & Sociedade Civil & Não reemb. & $\begin{array}{l}\text { Estudos/Projetos } \\
\text { (contratos) }\end{array}$ & 1811904 & PDC01 & 12 & $\begin{array}{l}\text { Objetivos específicos:- Elaboração de } \\
\text { releases coma cobertura das reuniões do } \\
\text { CBH, Cameras Técnica }\end{array}$ \\
\hline $\begin{array}{c}\text { SOS } \\
\text { ITUPARARANGA - } \\
\text { ORGANIZACÃ̃O DA } \\
\text { SOCIEDADE CIVIL DE }\end{array}$ & $\begin{array}{l}\text { PROTEÇ̃̃O DOS } \\
\text { RECURSOS } \\
\text { HÍDRICOS E } \\
\text { PROJETOS DE }\end{array}$ & Cancelado & 04/07/2016 & 0 & 0 & 0 & Sociedade Civil & Não reemb. & $\begin{array}{l}\text { Educacãa } \\
\text { Ambiental } \\
\text { (contratos) }\end{array}$ & 9000 & PDC01 & 12 & $\begin{array}{l}\text { OBJETIVO: O OBJETIVO PRINCIPAL DO } \\
\text { PROJETOÉ MINIMIZAR OS IIPACTOS } \\
\text { AMBIENTAIS IDENTIFICADOS NO } \\
\text { RESERV }\end{array}$ \\
\hline $\begin{array}{l}\text { PREFEITURA } \\
\text { MUNICIPALDE } \\
\text { CABREÚVA }\end{array}$ & $\begin{array}{l}\text { PREFEITURA } \\
\text { MUNICIPAL }\end{array}$ & Cancelado & 04/07/2016 & 0 & 0 & 0 & Município & Não reemb. & $\begin{array}{l}\text { Educação } \\
\text { Ambiental } \\
\text { (contratos) }\end{array}$ & 8000 & PDC01 & 12 & $\begin{array}{c}\text { TEM-SE COMO OBJETIVO GERAL DA } \\
\text { PROPOSTA O FORTALECIMENTO DA } \\
\text { ASSOCIAçãO DE COLETA SELETIVA } \\
\text { COM CATADOR }\end{array}$ \\
\hline $\begin{array}{c}\text { FUNDAÇÃ̃ DE } \\
\text { APOIO INSTIT.AO } \\
\text { DESENV.CIENTÍFICO } \\
\text { ETECNOL.DA } \\
\text { UNIVERS.FEDERAL } \\
\text { DE SÃO CARLOS (FAI- } \\
\text { UFSCar) }\end{array}$ & $\begin{array}{c}\text { APOIO } \\
\text { INSTITUCIONAL AO } \\
\text { DESENVOLVIMENTO } \\
\text { CIENTÍ́FICO E } \\
\text { I- TECNOLÓGICO DA }\end{array}$ & Cancelado & 04/07/2016 & 0 & 0 & 0 & Sociedade Civil & Não reemb. & $\begin{array}{l}\text { Educacãa } \\
\text { Ambiental } \\
\text { (contratos) }\end{array}$ & 8000 & PDC01 & 12 & $\begin{array}{l}\text { PRODUçãO E O DESENVOLVIMENTO DE } \\
\text { UM LIVRO LúDICO EPARADIDáTICO } \\
\text { REGIONAL QUE PERMITA A } \\
\text { SENSIBLIZAçãa }\end{array}$ \\
\hline $\begin{array}{c}\text { ASSOCIAÇ̃̃o } \\
\text { ECOAR FLORESTAL }\end{array}$ & $\begin{array}{l}\text { REALIZAÇÃO DE } \\
\text { PROJETOS } \\
\text { SOCIOAMBIENTAIS }\end{array}$ & Cancelado & 04/07/2016 & 0 & 0 & 0 & Sociedade Civil & Não reemb. & $\begin{array}{l}\text { Educação } \\
\text { Ambiental } \\
\text { (contratos) }\end{array}$ & 320 & PDC01 & 14 & $\begin{array}{l}\text { A PROPOSTA ENQUADRA-SENA } \\
\text { LINHA TEMáTICA PLANEJAMENTO E } \\
\text { GERENCIAMENTO DE RECURSOS } \\
\text { HIDRICOS - Açã̃O: C }\end{array}$ \\
\hline $\begin{array}{l}\text { PREFEITURA } \\
\text { MUNICIPAL DE } \\
\text { SOROCABA }\end{array}$ & PREFEITURA & Cancelado & 26/04/2017 & $360.803,22$ & $212.629,59$ & $573.432,81$ & Sociedade Civil & Não reemb. & $\begin{array}{l}\text { Educação } \\
\text { Ambiental } \\
\text { (contratos) }\end{array}$ & 600000 & $\mathrm{PDC} 01$ & 12 & $\begin{array}{l}\text { Objetivo Os objetivos aqui descritos } \\
\text { consideram as necessidades e urgências } \\
\text { locais e também o propos }\end{array}$ \\
\hline $\begin{array}{l}\text { CETESB - } \\
\text { COMPANHIA } \\
\text { AMBIENTAL DO } \\
\text { ESTADO DE SÃO } \\
\text { PAULO }\end{array}$ & $\begin{array}{c}\text { AGiENCIA } \\
\text { AMBIENTAL } \\
\text { ESTADUALDE } \\
\text { CONTROLEDA } \\
\text { POLUIÇÃOE } \\
\text { TFCNOI OIIA DF }\end{array}$ & Não iniciado & - & $3.503 .774,08$ & 934.924,98 & $4.438 .699,06$ & Estado & Não reemb. & $\begin{array}{l}\text { Planej. e Gerenc. } \\
\text { dos Recs. Hídricos } \\
\text { (contratos) }\end{array}$ & 1900000 & $\mathrm{PDC} 01$ & 24 & $\begin{array}{l}\text { Implantacã̃o de Infra estrutura adequada } \\
\text { para atender às demandas do órgão } \\
\text { colegiado regional de gest }\end{array}$ \\
\hline $\begin{array}{l}\text { CONSÓRCIO DE } \\
\text { ESTUDOS, } \\
\text { RECUPERAÇÃO E } \\
\text { DESENVOLVIMENTO } \\
\text { DA BACIA DOS RIOS } \\
\text { SOROCABA E MÉDIO } \\
\text { TIETÊ-CERISO }\end{array}$ & $\begin{array}{l}\text { CONSÓRCIO } \\
\text { INTERMUNICIPAL }\end{array}$ & Em execução & - & $3.195 .848,60$ & $61.960,33$ & $3.257 .808,93$ & Sociedade Civil & Não reemb. & $\begin{array}{l}\text { Estudos/Projetos } \\
\text { (contratos) }\end{array}$ & 1409274 & PDC08 & 24 & $\begin{array}{l}\text { COM AS LEIS AMBIENTAIS } \\
\text { ESTADUAIS EFEDERAIS, OS } \\
\text { MUNICIPIOS TEM SE PREOCUPADO } \\
\text { COM OS PROBLEMAS AMBIEN }\end{array}$ \\
\hline
\end{tabular}




\begin{tabular}{|c|c|c|c|c|c|c|c|c|c|c|c|c|c|}
\hline Nome do interessado & $\begin{array}{l}\text { Atividade principal do } \\
\text { interessado }\end{array}$ & $\begin{array}{l}\text { Situação do } \\
\text { empreendimento }\end{array}$ & $\begin{array}{c}\text { Data de } \\
\text { conclusão }\end{array}$ & Valor aprovado & $\begin{array}{c}\text { Valor de } \\
\text { contrapartida }\end{array}$ & Valor total & $\begin{array}{l}\text { Segmento do } \\
\text { interessado }\end{array}$ & Modalidade & $\begin{array}{l}\text { Benefício: } \\
\text { indicador }\end{array}$ & $\begin{array}{l}\text { População } \\
\text { beneficiada }\end{array}$ & PDC: sigla & $\begin{array}{l}\text { Tempo de } \\
\text { execução } \\
\text { (meses) }\end{array}$ & Descrição \\
\hline $\begin{array}{l}\text { PREFEITURA } \\
\text { MUNICIPAL DE } \\
\text { CAPELA DO ALTO }\end{array}$ & $\begin{array}{l}\text { PREFEITURA } \\
\text { MUNICIPAL }\end{array}$ & Emexecução & - & $383.008,28$ & $8.466,72$ & $391.475,00$ & Município & Não reemb. & $\begin{array}{l}\text { Trat. e Disposição } \\
\text { de Lixo - Obras } \\
\text { (habitantes) }\end{array}$ & 18646 & $\mathrm{PDC} 03$ & 5 & $\begin{array}{l}\text { ESTE PROJETO TEM COMO PRINCIPAL } \\
\text { OBJETIVO PREVENIR A POLUIÇ̃̃O DOS } \\
\text { RECURSOS HIDRICOSS PRESENTES NA } \\
\text { ARE }\end{array}$ \\
\hline $\begin{array}{c}\text { PREFEITURA } \\
\text { MUNICIPAL DE } \\
\text { CAPELA DO ALTO }\end{array}$ & $\begin{array}{l}\text { PREFEITURA } \\
\text { MUNICIPAL }\end{array}$ & Emexecução & - & $250.504,02$ & $4.204,48$ & $254.708,50$ & Município & Não reemb. & $\begin{array}{l}\text { Coletae } \\
\text { Tratamento de } \\
\text { Esgotos } \\
\text { (habitantes) }\end{array}$ & 380 & $\mathrm{PDC}_{3}$ & 6 & $\begin{array}{c}\text { ALCANCAR 100\% DE ESGOTO } \\
\text { TRATADO NO MUNICPIO DECAPELA } \\
\text { DO ALTO, O PROJETO PROPOSTO VAI } \\
\text { A ENCONTRO AS }\end{array}$ \\
\hline $\begin{array}{c}\text { PREFEITURA } \\
\text { MUNICIPAL DE } \\
\text { TORRE DE PEDRA }\end{array}$ & $\begin{array}{l}\text { PúBLICA/EXECUTIV } \\
\mathrm{A}\end{array}$ & Emexecução & - & $136.923,50$ & $4.966,50$ & $141.890,00$ & Município & Não reemb. & $\begin{array}{l}\text { Estudos/Projetos } \\
\text { (contratos) }\end{array}$ & 2279 & PDC09 & 5 & $\begin{array}{l}\text { O EMPREENDIMENTO EM QUESTãO } \\
\text { TEM COMO OBJETIVO A RECUPERAçãO } \\
\text { ERENATURALIZAçãO DO RIBEIRãO } \\
\text { TORRE DE P }\end{array}$ \\
\hline $\begin{array}{c}\text { PREFEITURA } \\
\text { MUNICIPAL DE } \\
\text { CAPELA DO ALTO }\end{array}$ & $\begin{array}{l}\text { PREFEITURA } \\
\text { MUNICIPAL }\end{array}$ & Emexecução & - & $219.557,50$ & $3.781,55$ & $223.339,05$ & Município & Não reemb. & $\begin{array}{l}\text { Coleta e } \\
\text { Tratamento de } \\
\text { Esgotos } \\
\text { (habitantes) }\end{array}$ & 380 & $\mathrm{PDCO}_{3}$ & 6 & $\begin{array}{c}\text { ALCANÇAR 100\% DE ESGOTO } \\
\text { TRATADO NO MUNICÍPIO DE CAPELA } \\
\text { DO ALTO, O PROJETO PROPOSTO VAI } \\
\text { A ENCONTRO AS }\end{array}$ \\
\hline $\begin{array}{l}\text { PREFEITURA } \\
\text { MUNICIPALDE } \\
\text { LARANJAL } \\
\text { PAULISTA }\end{array}$ & $\begin{array}{l}\text { PREFEITURA } \\
\text { MUNICIPAL }\end{array}$ & Cancelado & 04/07/2016 & 0 & 0 & 0 & Municííio & Não reemb. & $\begin{array}{l}\text { Trat. e Disposição } \\
\text { de Lixo - Obras } \\
\text { (habitantes) }\end{array}$ & 26000 & PDC09 & 18 & $\begin{array}{l}\text { FAZER UM MAPEAMENTOE } \\
\text { DIAGNOSTICOS DAS NASCENTES } \\
\text { PARA AUXILIAR NAS POLITICAS } \\
\text { PUBLICAS DO MUNICIPIO. }\end{array}$ \\
\hline $\begin{array}{l}\text { PREFEITURA } \\
\text { MUNICIPALDE } \\
\text { JUMIRIM }\end{array}$ & $\begin{array}{l}\text { PREFEITURA } \\
\text { MUNICIPAL }\end{array}$ & Emexecução & & $138.033,00$ & $2.782,38$ & $140.815,38$ & Município & Não reemb. & $\begin{array}{l}\text { Coleta e } \\
\text { Tratamento de } \\
\text { Esgotos } \\
\text { (habitantes) }\end{array}$ & 3092 & $\mathrm{PDC} 03$ & 12 & $\begin{array}{c}\text { OS GRANDES PROBLEMAS } \\
\text { AMBIENTAIS EO CONSEQUENTE } \\
\text { AUMENTO DA CONSCIENTIZAção EM } \\
\text { TORNO DAS EXIGêNCIAS N }\end{array}$ \\
\hline $\begin{array}{l}\text { PREFEITURA } \\
\text { MUNICIPAL DE } \\
\text { JUMIRIM }\end{array}$ & $\begin{array}{l}\text { PREFEITURA } \\
\text { MUNICIPAL }\end{array}$ & Emexecução & & $138.063,63$ & $2.698,00$ & $140.761,63$ & Município & Não reemb. & $\begin{array}{l}\text { Coleta e } \\
\text { Tratamento de } \\
\text { Esgotos } \\
\text { (habitantes) }\end{array}$ & 3092 & $\mathrm{PDC} 03$ & 12 & $\begin{array}{c}\text { OS GRANDES PROBLEMAS } \\
\text { AMBIENTAIS EO CONSEQUENTE } \\
\text { AUMENTO DA CONSCIENTIZAçã̃ EM } \\
\text { TORNO DAS EXIGêNCIAS N }\end{array}$ \\
\hline $\begin{array}{l}\text { PREFEITURA } \\
\text { MUNICIPAL DE } \\
\text { SARAPUí }\end{array}$ & $\begin{array}{l}\text { ADMINISTRAção } \\
\text { PUBLICA } \\
\text { MUNICIPAL }\end{array}$ & Cancelado & 04/07/2016 & 0 & 0 & 0 & Município & Não reemb. & $\begin{array}{l}\text { Estudos/Projetos } \\
\text { (contratos) }\end{array}$ & 4500 & PDC09 & 6 & $\begin{array}{c}\text { CONTRATAção DE EMPRESA } \\
\text { ESPECIALIZADA PARA A REALIZAção } \\
\text { DE UM DIAGNóSTICO AMPLO SOBRE A } \\
\text { ATUAL SITUAçã }\end{array}$ \\
\hline $\begin{array}{l}\text { PREFEITURA } \\
\text { MUNICIPAL DE } \\
\text { BOITUVA }\end{array}$ & $\begin{array}{l}\text { ORGãO PUBLICO } \\
\text { (PREFEITURA) }\end{array}$ & Emexecução & - & $382.000,00$ & $48.600,00$ & $430.600,00$ & Município & Não reemb. & $\begin{array}{l}\text { Planej. e Gerenc. } \\
\text { dos Recs. Hidricos } \\
\text { (contratos) }\end{array}$ & 54000 & $\mathrm{PDC} 03$ & 6 & $\begin{array}{c}\text { A CONTEINERIZAção, ENTRE } \\
\text { DIVERSOS BENEFiCIOS ALéM DA } \\
\text { COLETA MECANIZADA, PERMITEO } \\
\text { ARMAZENAMENTO ADEQ }\end{array}$ \\
\hline $\begin{array}{c}\text { SERVIÇO } \\
\text { AUTÔNOMO DE } \\
\text { ÁGUA EESGOTO DE } \\
\text { PORTO FELIZ (SAAE) }\end{array}$ & $\begin{array}{l}\text { PREFEITURA } \\
\text { MUNICIPAL }\end{array}$ & Cancelado & 04/07/2016 & 0 & 0 & 0 & Município & Não reemb. & $\begin{array}{l}\text { Abastecimento de } \\
\text { Água (habitantes) }\end{array}$ & 43395 & PDC05 & 4 & $\begin{array}{l}\text { PRESERVAçãO DO úNICO MANANCIAL } \\
\text { DO MUNICIPIO, POR MEIO DE } \\
\text { PROGRAMA DECOMBATEà PERDAS } \\
\text { DE áGUA NAS RE }\end{array}$ \\
\hline $\begin{array}{c}\text { SERVIÇO } \\
\text { AUTÔNOMO DE } \\
\text { ÁGUA EESGOTO DE } \\
\text { PORTO FELZZ (SAAE) }\end{array}$ & $\begin{array}{l}\text { PREFEITURA } \\
\text { MUNICIPAL }\end{array}$ & Emexecução & - & $176.953,13$ & $9.083,30$ & $186.036,43$ & Município & Não reemb. & $\begin{array}{l}\text { Estudos/Projetos } \\
\text { (contratos) }\end{array}$ & 43395 & PDC05 & 6 & $\begin{array}{l}\text { CONTINUIDADE AO PLANO DIRETOR } \\
\text { DE COMBATEà PERDAS DE áGUA }\end{array}$ \\
\hline $\begin{array}{c}\text { SERVIÇO } \\
\text { AUTÔNOMO DE } \\
\text { ÁGUA EESGOTO DE } \\
\text { PORTO FELIZ (SAAE) }\end{array}$ & $\begin{array}{l}\text { PREFEITURA } \\
\text { MUNICIPAL }\end{array}$ & Emexecução & - & $133.524,27$ & $13.145,26$ & $146.669,53$ & Município & Não reemb. & $\begin{array}{l}\text { Abastecimento de } \\
\text { Água (habitantes) }\end{array}$ & 48893 & $\mathrm{PDC} 03$ & 6 & $\begin{array}{c}\text { ELIMINAç̃̃o DOS IMPACTOS } \\
\text { AMBIENTAIS COM A POLUIçãO QUE } \\
\text { AS áGUA DELAVAGEM PRODUZEM } \\
\text { AO SEREM LANÇADAS }\end{array}$ \\
\hline $\begin{array}{l}\text { PREFEITURA } \\
\text { MUNICIPALDE } \\
\text { VOTORANTIM }\end{array}$ & $\begin{array}{l}\text { PREFEITURA } \\
\text { MUNICIPAL }\end{array}$ & Cancelado & 04/07/2016 & 0 & 0 & 0 & Município & Não reemb. & $\begin{array}{l}\text { Recomposição de } \\
\text { Mata Ciliar } \\
\text { (hectares) }\end{array}$ & 15000 & PDC09 & 36 & $\begin{array}{c}\text { A READEQUAÇ̃̃O DO VIVEIRO } \\
\text { MUNICIPALDE MUDAS, OBJETIVA } \\
\text { TRATAR E SEMEAR CORRETAMENTE } \\
\text { AS SEMENTES EM ES }\end{array}$ \\
\hline $\begin{array}{l}\text { PREFEITURA } \\
\text { MUNICIPALDE } \\
\text { PIEDADE }\end{array}$ & $\begin{array}{l}\text { PREFEITURA } \\
\text { MUNICIPAL }\end{array}$ & Não iniciado & - & $316.745,84$ & $8.889,85$ & $325.635,69$ & Município & Não reemb. & $\begin{array}{l}\text { Trat. e Disposição } \\
\text { de Lixo - Obras } \\
\text { (habitantes) }\end{array}$ & 52214 & PDC04 & 18 & $\begin{array}{l}\text { O CONSUMO DESCONTROLADO DE } \\
\text { RECURSOS NATURAIS, A GERAçãO } \\
\text { CRESCENTE DE RESIDUOS SóLIDOS, OS } \\
\text { POUCOS CUI }\end{array}$ \\
\hline
\end{tabular}




\begin{tabular}{|c|c|c|c|c|c|c|c|c|c|c|c|c|c|}
\hline Nome do interessado & $\begin{array}{l}\text { Atividade principal do } \\
\text { interessado }\end{array}$ & $\begin{array}{l}\text { Situação do } \\
\text { empreendimento }\end{array}$ & $\begin{array}{l}\text { Data de } \\
\text { conclusão }\end{array}$ & Valor aprovado & $\begin{array}{c}\text { Valor de } \\
\text { contrapartida }\end{array}$ & Valor total & $\begin{array}{l}\text { Segmento do } \\
\text { interessado }\end{array}$ & Modalidade & $\begin{array}{l}\text { Benefício: } \\
\text { indicador }\end{array}$ & $\begin{array}{l}\text { População } \\
\text { beneficiada }\end{array}$ & PDC: sigla & $\begin{array}{l}\text { Tempo de } \\
\text { execução } \\
\text { (meses) }\end{array}$ & Descrição \\
\hline $\begin{array}{c}\text { SERVIÇO } \\
\text { AUTOONOMO DE } \\
\text { ÁGUA EESGOTO DE } \\
\text { CERQULHO }\end{array}$ & $\begin{array}{l}\text { SERVIÇO DE } \\
\text { SANEAMENTO } \\
\text { BÁSICO }\end{array}$ & Em execução & - & $390.383,18$ & $124.725,00$ & $515.108,18$ & Município & Não reemb. & $\begin{array}{l}\text { Abastecimento de } \\
\text { Água (habitantes) }\end{array}$ & 39617 & PDC05 & 6 & $\begin{array}{l}\text { OBJETIVO: O OBJETO DO PRESENTE } \\
\text { TRABALHO A A CONTRATAçãO DE } \\
\text { EMPRESA ESPECIALIZADA PARA } \\
\text { EXECUção DE SE }\end{array}$ \\
\hline $\begin{array}{l}\text { FUNDAÇÃO DE } \\
\text { ESTUDOS E } \\
\text { PESQUISAS } \\
\text { AGRÍCOLASE } \\
\text { FLORESTAIS }\end{array}$ & $\begin{array}{c}\text { PESQUISA E } \\
\text { DESENVOLVIMENTO } \\
\text { EXPERIMENTAL EM } \\
\text { CIÊNCIAS Fí́ICAS E } \\
\text { NATURAIS }\end{array}$ & Cancelado & $04 / 07 / 2016$ & 0 & 0 & 0 & Sociedade Civil & Não reemb. & $\begin{array}{l}\text { Estudos/Projetos } \\
\quad \text { (contratos) }\end{array}$ & 200000 & PDC03 & 12 & $\begin{array}{l}\text { ÓLEOS USADOS, SEJAM } \\
\text { LUBRIFCANTES OU DE COZINHA, } \\
\text { REPREEENTAM UMA IMPORTANTE } \\
\text { FONTE DE POLUENTES NOS C }\end{array}$ \\
\hline $\begin{array}{c}\text { SERVIÇO } \\
\text { AUTÔNOMO DE } \\
\text { ÁGUA EESGOTO DE } \\
\text { CERQUILHO }\end{array}$ & $\begin{array}{l}\text { SERVIÇO DE } \\
\text { SANEAMENTO } \\
\text { BÁSICO }\end{array}$ & Emexecução & - & $384.867,32$ & $121.231,24$ & $506.098,56$ & Município & Não reemb. & $\begin{array}{l}\text { Abastecimento de } \\
\text { Água (habitantes) }\end{array}$ & 39617 & PDC05 & 6 & $\begin{array}{l}\text { OBJETIVO: O OBJETO DO PRESENTE } \\
\text { TRABALHO A A CONTRATAçãO DE } \\
\text { EMPRESA ESPECIALIZADA PARA } \\
\text { EXECUÇão DE SE }\end{array}$ \\
\hline $\begin{array}{l}\text { FUNDAÇÃO DE } \\
\text { ESTUDOS E } \\
\text { PESQUISAS } \\
\text { AGRÍCOLAS E } \\
\text { FLORESTAIS }\end{array}$ & $\begin{array}{c}\text { PESQUISA E } \\
\text { DESENVOLVIMENTO } \\
\text { EXPERIMENTALEM } \\
\text { CIÊNCIAS FÍSICAS E } \\
\text { NATURAIS }\end{array}$ & Cancelado & $04 / 07 / 2016$ & 0 & 0 & 0 & Sociedade Civil & Não reemb. & $\begin{array}{l}\text { Estudos/Projetos } \\
\text { (contratos) }\end{array}$ & 80000 & PDC01 & 12 & $\begin{array}{l}\text { DESENVOLVER ESTUDOS PARA } \\
\text { SUBSIDIAR O PLANO DE MANEJO DA } \\
\text { MICROBACIA HIDROGRáFICA DO } \\
\text { RIBEIRãO AVECUIA }\end{array}$ \\
\hline $\begin{array}{l}\text { PREFEITURA } \\
\text { MUNICIPALDE } \\
\text { BOITUVA }\end{array}$ & $\begin{array}{l}\text { ORGäO PUBLICO } \\
\text { (PREFEITURA) }\end{array}$ & Não iniciado & & $390.853,10$ & $27.683,25$ & $418.536,35$ & Município & Não reemb. & $\begin{array}{l}\text { Estudos/Projetos } \\
\text { (contratos) }\end{array}$ & 48314 & PDC09 & 18 & $\begin{array}{l}\text { LEVANTAMENTO DE FRAGMENTOS } \\
\text { FLORESTAIS PARA CONSERVAÇÃO DA } \\
\text { VEGETAÇÃO DA BIODIVERSIDADEE } \\
\text { DOS RECURSOS }\end{array}$ \\
\hline $\begin{array}{l}\text { UNIVERSIDADE } \\
\text { ESTADUAL }\end{array}$ & $\begin{array}{l}\text { UNIVERSIDADE } \\
\text { PÚBLICA }\end{array}$ & Não iniciado & - & $197.370,00$ & $21.930,00$ & $219.300,00$ & Estado & Não reemb. & $\begin{array}{l}\text { Estudos/Projetos } \\
\quad \text { (contratos) }\end{array}$ & 50000 & PDC01 & 12 & $\begin{array}{l}\text { GERAção DE DIVERSAS INFORMAçõES } \\
\text { DE ORDEM ESPACIAL, SOCIALE }\end{array}$ \\
\hline $\begin{array}{l}\text { PREFEITURA } \\
\text { MUNICIPALDDE } \\
\text { CERQUILHO }\end{array}$ & $\begin{array}{l}\text { PREFEITURA } \\
\text { MUNICIPAL }\end{array}$ & Concluído & $25 / 05 / 2017$ & $512.805,33$ & $190.677,14$ & $703.482,47$ & Município & Não reemb. & $\begin{array}{l}\text { Trat. e Disposicã̃o } \\
\text { de Lixo - Obras } \\
\text { (habitantes) }\end{array}$ & 39649 & PDC03 & 6 & $\begin{array}{c}\text { O MOTIVO PELO QUAL ESSES } \\
\text { DETALHAMENTOS DE PROJETOS } \\
\text { PARCIAIS SãO EXECUTADOS é PARA } \\
\text { PROPICIAR QUE O AT }\end{array}$ \\
\hline $\begin{array}{c}\text { PREFEITURA } \\
\text { MUNICIPAL DE } \\
\text { ARAÇOIABA DA } \\
\text { SERRA }\end{array}$ & $\begin{array}{l}\text { PREFEITURA } \\
\text { MUNICIPAL }\end{array}$ & Emexecução & - & $143.087,45$ & $4.355,06$ & $147.442,51$ & Municííio & Não reemb. & $\begin{array}{l}\text { Estudos/Projetos } \\
\text { (contratos) }\end{array}$ & 29351 & PDC03 & 4 & $\begin{array}{c}\text { O ATERRO SANITáRIO PRESENTE NO } \\
\text { MUNICIIPIO ENCONTRA-SE NO LIMITE } \\
\text { DE SUA CAPACIDADE, ASSIM A } \\
\text { PREFEITURA }\end{array}$ \\
\hline $\begin{array}{l}\text { UNIVERSIDADE } \\
\text { ESTADUAL } \\
\text { PAULISTA JULIO DE } \\
\text { MESQUITA FILHO- }\end{array}$ & $\begin{array}{l}\text { UNIVERSIDADE } \\
\text { PÚBLICA }\end{array}$ & Emexecução & & $303.197,00$ & $96.000,00$ & $399.197,00$ & Estado & Não reemb. & $\begin{array}{l}\text { Planej. Ge Gerenc. } \\
\text { dos Recs. Híndicos } \\
\text { (contratos) }\end{array}$ & 1000000 & PDC01 & 12 & $\begin{array}{c}\text { IMPLANTAÇ̃̃O DOS } \\
\text { MONITORAMENTOS } \\
\text { HIDROMETEOROLÓGICOS E } \\
\text { HIDROGEOQUÍMICOS NA BACIA DO }\end{array}$ \\
\hline $\begin{array}{l}\text { PREFEITURA } \\
\text { MUNICIPALDE } \\
\text { ARAÇOIABA DA } \\
\text { SERRA }\end{array}$ & $\begin{array}{l}\text { PREFEITURA } \\
\text { MUNICIPAL }\end{array}$ & Emexecução & - & $626.508,69$ & $12.785,89$ & $639.294,58$ & Município & Não reemb. & $\begin{array}{l}\text { Trat. e Disposicã̃o } \\
\text { de Lixo - Obras } \\
\text { (habitantes) }\end{array}$ & 28804 & PDC03 & 8 & $\begin{array}{l}\text { CUMPRIMENTO DA LEGISLAÇãO E } \\
\text { PLANODE METAS DA RECICLAGEM DE } \\
\text { RSU. FORTALECIMENTO DA COELTA } \\
\text { SELETIVA NO }\end{array}$ \\
\hline $\begin{array}{l}\text { PREFEITURA } \\
\text { MUNICIPALDE } \\
\text { CABREÚVA }\end{array}$ & $\begin{array}{l}\text { PREFEITURA } \\
\text { MUNICIPAL }\end{array}$ & Cancelado & 04/07/2016 & 0 & 0 & 0 & Município & Não reemb. & $\begin{array}{l}\text { Estudos/Projetos } \\
\text { (contratos) }\end{array}$ & 45000 & PDC01 & 12 & $\begin{array}{l}\text { CARACTERIZAR, ELABORAR O } \\
\text { DIAGNóSTICO SOCIOAMBIENTALE } \\
\text { PROPOR O PLANO DE MANEJO DAS } \\
\text { MICROBACIAS HIDRO }\end{array}$ \\
\hline $\begin{array}{l}\text { UNIVERSIDADE } \\
\text { ESTADUAL } \\
\text { PAULISTA JULIO DE } \\
\text { MESQUITA FILHO- } \\
\text { UNESP CAMPUS }\end{array}$ & $\begin{array}{l}\text { UNIVERSIDADE } \\
\text { PÚBLICA }\end{array}$ & Em execução & & $315.072,52$ & $72.000,00$ & $387.072,52$ & Estado & Não reemb. & $\begin{array}{l}\text { Planej. e Gerenc. } \\
\text { dos Recs. Hídricos } \\
\text { (contratos) }\end{array}$ & 1000000 & PDC01 & 12 & $\begin{array}{c}\text { FAZER O DIAGNÓSTICO AMBIENTAL } \\
\text { DE ÁREAS DE MANANCIAIS EM SUB- } \\
\text { BACIAS DO RIO SOROCABA MÉDIO } \\
\text { TIETÊ PARA }\end{array}$ \\
\hline $\begin{array}{l}\text { PREFEITURA } \\
\text { MUNICIPALDE } \\
\text { PORTO FELIZ }\end{array}$ & $\begin{array}{l}\text { PREFEITURA } \\
\text { MUNICIPAL }\end{array}$ & Cancelado & 04/07/2016 & 0 & 0 & 0 & Município & Não reemb. & $\begin{array}{l}\text { Estudos/Projetos } \\
\quad \text { (contratos) }\end{array}$ & 51320 & PDC03 & 12 & $\begin{array}{l}\text { TEM-SE COMO OBJETIVO GERAL } \\
\text { REGULARIZAR PERANTE A CETESB O } \\
\text { ANTIGO ATERRO DE LIXO URBANO DO } \\
\text { MUNICÍPIO }\end{array}$ \\
\hline $\begin{array}{l}\text { PREFEITURA } \\
\text { MUNICIPALDE } \\
\text { BOFETE }\end{array}$ & $\begin{array}{l}\text { PREFEITURA } \\
\text { MUNICIPAL }\end{array}$ & Em execução & & $294.936,10$ & $6.007,60$ & $300.943,70$ & Município & Não reemb. & $\begin{array}{l}\text { Coleta e } \\
\text { Tratamento de } \\
\text { Esgotos } \\
\text { (habitantes) }\end{array}$ & 600 & PDC03 & 12 & $\begin{array}{c}\text { O OBJETIVO DO PRESENTE TERMO DE } \\
\text { REFERêNCIA é DAR DIRETRIZES PARA } \\
\text { A CONTRATAçã DE EMPRESA DE } \\
\text { ENGENHA }\end{array}$ \\
\hline $\begin{array}{l}\text { PREFEITURA } \\
\text { MUNICIPALDDE } \\
\text { LARANJAL } \\
\text { PAULISTA }\end{array}$ & $\begin{array}{l}\text { PREFEITURA } \\
\text { MUNICIPAL }\end{array}$ & Em execução & - & $482.289,36$ & $8.561,20$ & $490.850,56$ & Município & Não reemb. & $\begin{array}{l}\text { Trat. e Disposição } \\
\text { de Lixo - Obras } \\
\text { (habitantes) }\end{array}$ & 26640 & PDC03 & 11 & $\begin{array}{c}\text { MELHORAR A GESTãO DE RESIDUOS } \\
\text { SóLIDOS NO MUNICIPIO SENDO UMA } \\
\text { DAS PRIORIDADES DO PLANO DE } \\
\text { BACIA, A ME }\end{array}$ \\
\hline
\end{tabular}




\begin{tabular}{|c|c|c|c|c|c|c|c|c|c|c|c|c|c|}
\hline Nome do interessado & $\begin{array}{l}\text { Atividade principal do } \\
\text { interessado }\end{array}$ & $\begin{array}{c}\text { Situação do } \\
\text { empreendimento }\end{array}$ & $\begin{array}{l}\text { Data de } \\
\text { conclusão }\end{array}$ & Valor aprovado & $\begin{array}{l}\text { Valor de } \\
\text { contrapartida }\end{array}$ & Valor total & $\begin{array}{l}\text { Segmento do } \\
\text { interessado }\end{array}$ & Modalidade & $\begin{array}{l}\text { Benefício: } \\
\text { indicador }\end{array}$ & $\begin{array}{l}\text { População } \\
\text { beneficiada }\end{array}$ & PDC: sigla & $\begin{array}{l}\text { Tempo de } \\
\text { execução } \\
\text { (meses) }\end{array}$ & Descrição \\
\hline $\begin{array}{c}\text { SERVICO } \\
\text { AUTONOMO DE } \\
\text { AGUA, ESGOTO E } \\
\text { MEIO AMBIENTE- } \\
\text { SAAEAMBIENTAL }\end{array}$ & $\begin{array}{l}\text { SETOR DE } \\
\text { SANEAMENTO } \\
\text { BáSICO }\end{array}$ & Cancelado & 04/07/2016 & 0 & 0 & 0 & Município & Não reemb. & $\begin{array}{l}\text { Planej. e Gerenc. } \\
\text { dos Recs. Hídricos } \\
\text { (contratos) }\end{array}$ & 105569 & PDC01 & 12 & 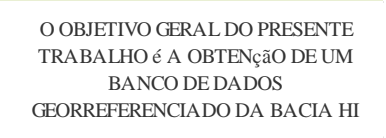 \\
\hline $\begin{array}{c}\text { SERVIÇO } \\
\text { AUTÔNOMO } \\
\text { MUNICIPAL DE } \\
\text { ÁGUA EESGOTO DE } \\
\text { TIETÊ- SAMAE }\end{array}$ & $\begin{array}{l}\text { SANEAMENTO } \\
\text { PÚBLICO }\end{array}$ & Não iniciado & & $2.886 .475,73$ & $288.647,56$ & $3.175 .123,29$ & Município & Não reemb. & $\begin{array}{l}\text { Abastecimento de } \\
\text { Água (habitantes) }\end{array}$ & 40000 & PDC05 & 12 & $\begin{array}{c}\text { AUMENTAR A RESERVAç̃o DE áGUA } \\
\text { EM PONTOS ESTRATéGICOS DE TODA } \\
\text { A áREA URBANA DA CIDADE, } \\
\text { OTIMIZAR A DIS }\end{array}$ \\
\hline $\begin{array}{l}\text { SERVICCO } \\
\text { AUTÔNOMO DE } \\
\text { ÁGUA EESGOTO DE } \\
\text { CERQULHO }\end{array}$ & $\begin{array}{l}\text { SERVIÇO DE } \\
\text { SANEAMENTO } \\
\text { BÁSICO }\end{array}$ & Cancelado & 05/05/2017 & 0 & 0 & 0 & Município & Não reemb. & $\begin{array}{l}\text { Estudos/Projetos } \\
\text { (contratos) }\end{array}$ & 39617 & $\mathrm{PDC}_{3}$ & 6 & $\begin{array}{l}\text { OBJETIVO: ELABORAR UM PROJETO DE } \\
\text { ATERRO SANITáRIO QUE DEVERá SER } \\
\text { IMPLANTADO EM UMA LAGOA } \\
\text { FACULTATIVA }\end{array}$ \\
\hline $\begin{array}{l}\text { PREFEITURA } \\
\text { MUNICIPALDE } \\
\text { CERQUILHO }\end{array}$ & $\begin{array}{l}\text { PREFEITURA } \\
\text { MUNICIPAL }\end{array}$ & Não iniciado & & $257.279,21$ & $64.319,81$ & $321.599,02$ & Município & Não reemb. & $\begin{array}{l}\text { Trat. e Disposição } \\
\text { de Lixo - Obras } \\
\text { (habitantes) }\end{array}$ & 39649 & $\mathrm{PDC} 03$ & 6 & $\begin{array}{l}\text { FINALIZAR A TERCEIRA FASE DO } \\
\text { ATERRO SANITáRIO DE CERQUILHO } \\
\text { PARA RECEBER AS ATUAIS } 25 \\
\text { TONELADAS DIáRI }\end{array}$ \\
\hline $\begin{array}{l}\text { PREFEITURA } \\
\text { MUNICIPAL DE } \\
\text { CAPELA DO ALTO }\end{array}$ & $\begin{array}{l}\text { PREFEITURA } \\
\text { MUNICIPAL }\end{array}$ & Não iniciado & - & $211.533,00$ & $4.317,00$ & $215.850,00$ & Município & Não reemb. & $\begin{array}{l}\text { Estudos/Projetos } \\
\text { (contratos) }\end{array}$ & 19482 & PDC01 & 7 & $\begin{array}{l}\text { ESTE PROJETO TEM O OBJETIVO DE } \\
\text { DAR PROSSEGUIMENTO AO } \\
\text { GERENCIAMENTO DA ́́REA DO } \\
\text { ANTIGO VAZADOURO DE RE }\end{array}$ \\
\hline $\begin{array}{c}\text { SERVIÇO } \\
\text { AUTÔNOMO DE } \\
\text { ÁGUA EESGOTO DE } \\
\text { PORTO FELIZ (SAAE) }\end{array}$ & $\begin{array}{l}\text { PREFEITURA } \\
\text { MUNICIPAL }\end{array}$ & Não iniciado & & $133.335,00$ & $14.815,00$ & $148.150,00$ & Município & Não reemb. & $\begin{array}{c}\text { Coleta e } \\
\text { Tratamento de } \\
\text { Esgotos } \\
\text { (habitantes) }\end{array}$ & 43395 & $\mathrm{PDC}_{3}$ & 6 & $\begin{array}{l}\text { PREVER CRESCIMENTO DO MUNICIPIO, } \\
\text { GARANTINDO COLETA E TRANSPORTE } \\
\text { DE ESGOTO SANITŔRIO DE FORMA } \\
\text { PLANEIA }\end{array}$ \\
\hline $\begin{array}{c}\text { SERVIÇO } \\
\text { AUTOONOMO DE } \\
\text { ÁGUA EEGOTO DE } \\
\text { PORTO FELIZ (SAAE) }\end{array}$ & $\begin{array}{l}\text { PREFEITURA } \\
\text { MUNICIPAL }\end{array}$ & Não iniciado & - & $289.390,99$ & $32.154,56$ & $321.545,55$ & Município & Não reemb. & $\begin{array}{l}\text { Abastecimento de } \\
\text { Água (habitantes) }\end{array}$ & 19676 & PDC05 & 5 & $\begin{array}{l}\text { CONTINUIDADE AO PROGRAMA DE } \\
\text { COMBATEà PERDAS }\end{array}$ \\
\hline $\begin{array}{c}\text { SOS } \\
\text { ITUPARARANGA - } \\
\text { ORGANIZAÇÃO DA } \\
\text { SOCIEDADE CIVIL DE } \\
\text { INTERESSE PÚBLICO }\end{array}$ & $\begin{array}{l}\text { PROTEÇÃO DOS } \\
\text { RECURSOS } \\
\text { HÍDRICOS E } \\
\text { PROJETOS DE } \\
\text { EDUCAÇÃO } \\
\text { AMBIENTAL }\end{array}$ & Não iniciado & & $399.923,25$ & $48.533,40$ & $448.456,65$ & Sociedade Civil & Não reemb. & $\begin{array}{l}\text { Coleta e } \\
\text { Tratamento de } \\
\text { Esgotos } \\
\text { (habitantes) }\end{array}$ & 50 & PDC01 & 12 & $\begin{array}{l}\text { 4.1. OBJETIVO GERAL: CONTRIBUIR } \\
\text { COM A MELHORIA DA QUALIDADE } \\
\text { DOS RECURSOS HIIRICOS DA } \\
\text { MICROBACIA DO S }\end{array}$ \\
\hline $\begin{array}{l}\text { PREFEITURA } \\
\text { MUNICIPAL DE } \\
\text { BOITUVA }\end{array}$ & $\begin{array}{l}\text { ORGão PUBLLCO } \\
\text { (PREFEITURA) }\end{array}$ & Não iniciado & & $339.001,33$ & $18.783,71$ & $357.785,04$ & Município & Não reemb. & $\begin{array}{l}\text { Trat. e Disposição } \\
\text { de Lixo - Obras } \\
\text { (habitantes) }\end{array}$ & 39000 & $\mathrm{PDC} 03$ & 4 & PDC-3 \\
\hline $\begin{array}{l}\text { PREFEITURA } \\
\text { MUNICIPAL DE } \\
\text { TATUÍ }\end{array}$ & $\begin{array}{l}\text { PREFEITURA } \\
\text { MUNICIPAL }\end{array}$ & Não iniciado & & $312.844,50$ & $16.465,50$ & $329.310,00$ & Município & Não reemb. & $\begin{array}{l}\text { Trat. e Disposição } \\
\text { de Lixo - Obras } \\
\text { (habitantes) }\end{array}$ & 117000 & $\mathrm{PDC} 03$ & 7 & $\begin{array}{l}\text { JUSTIFICATIVA DE SER A TOMADORA } \\
\text { PARA O EMPREENDIMENTO: A } \\
\text { REESTRUTURǍ̧ãO DA COOPERATIVA } \\
\text { ESTá FORTEMEN }\end{array}$ \\
\hline $\begin{array}{c}\text { SERVIÇO } \\
\text { AUTÔNOMO } \\
\text { MUNICIPAL DE } \\
\text { ÁGUA EESGOTO DE } \\
\text { TIETÊ- SAMAE }\end{array}$ & $\begin{array}{l}\text { SANEAMENTO } \\
\text { PÚBLICO }\end{array}$ & Não iniciado & - & $302.721,97$ & $33.635,78$ & $336.357,75$ & Município & Não reemb. & $\begin{array}{l}\text { Abastecimento de } \\
\text { Água (habitantes) }\end{array}$ & 12384 & PDC05 & 6 & $\begin{array}{l}\text { OTIMIZAR O CONSUMO E REDUZIR AS } \\
\text { PERDAS DE áGUA ATRAAVÉS DA } \\
\text { SUBSTITUIÇãO DOS HIDRôMETROS } \\
\text { MAIS ANTIGOS }\end{array}$ \\
\hline $\begin{array}{l}\text { SERVIÇO } \\
\text { AUTÔNOMO DE } \\
\text { ÁGUA EESGOTO DE } \\
\text { CERQUILHO } \\
\text { AGÊNCIA }\end{array}$ & $\begin{array}{l}\text { SERVIÇO DE } \\
\text { SANEAMENTO } \\
\text { BÁSICO }\end{array}$ & Não iniciado & & $224.459,57$ & 24.939,95 & $249.399,52$ & Município & Não reemb. & $\begin{array}{l}\text { Estudos/Projetos } \\
\text { (contratos) }\end{array}$ & 8750 & $\mathrm{PDC0} 3$ & 6 & $\begin{array}{l}\text { OBJETIVO: ELABORAR PROJETO DO } \\
\text { SISTEMA DE COLETA, AFASTAMENTO } \\
\text { E TRATAMENTO DE ESGOTO } \\
\text { SANITáRIO PARA A }\end{array}$ \\
\hline $\begin{array}{l}\text { REGULADORA DE } \\
\text { SERVIÇOS } \\
\text { DELEGADOS DO } \\
\text { MUNICÍPIO DA } \\
\text { ESTÂNCIA } \\
\text { TURÍSTICA DE ITU - }\end{array}$ & $\begin{array}{l}\text { SANEAMENTO } \\
\text { BÁSICO }\end{array}$ & Não iniciado & - & $185.881,36$ & $93.765,64$ & $279.647,00$ & Município & Não reemb. & $\begin{array}{l}\text { Planej. . Gerenc. } \\
\text { dos Recs. Hídricos } \\
\text { (contratos) }\end{array}$ & 156000 & PDC01 & 12 & $\begin{array}{c}\text { COMO SISTEMA EMERGENCIAL DE } \\
\text { REFORçO AO ATUAL SISTEMA DE } \\
\text { PRODUÇã̃O DE áGUANO MUNICIIIO, O } \\
\text { MONITORAMENT }\end{array}$ \\
\hline
\end{tabular}




\begin{tabular}{|c|c|c|c|c|c|c|c|c|c|c|c|c|c|}
\hline Nome do interessado & $\begin{array}{l}\text { Atividade principal do } \\
\text { interessado }\end{array}$ & $\begin{array}{l}\text { Situação do } \\
\text { empreendimento }\end{array}$ & $\begin{array}{l}\text { Data de } \\
\text { conclusão }\end{array}$ & Valor aprovado & $\begin{array}{c}\text { Valor de } \\
\text { contrapartida }\end{array}$ & Valor total & $\begin{array}{l}\text { Segmento do } \\
\text { interessado }\end{array}$ & Modalidade & $\begin{array}{l}\text { Benefício: } \\
\text { indicador }\end{array}$ & $\begin{array}{c}\text { Populacão } \\
\text { beneficiada }\end{array}$ & PDC: sigla & $\begin{array}{l}\text { Tempo de } \\
\text { execução } \\
\text { (meses) }\end{array}$ & Descrição \\
\hline $\begin{array}{l}\text { PREFEITURA } \\
\text { MUNICIPAL DE } \\
\text { CONCHAS }\end{array}$ & $\begin{array}{l}\text { PREFEITURA } \\
\text { MUNICIPAL }\end{array}$ & Cancelado & $11 / 01 / 2017$ & 0 & 0 & 0 & Município & Não reemb. & $\begin{array}{l}\text { Estudos/Projetos } \\
\text { (contratos) }\end{array}$ & 17162 & $\mathrm{PDC} 03$ & 6 & $\begin{array}{c}\text { O PROJETO A SER DESENVOLVIDO E } \\
\text { ELABORADO VISA EQUACIONAR } \\
\text { ADEQUADAMENTE SOB OS PONTOS } \\
\text { DE VISTA LEGAL, }\end{array}$ \\
\hline $\begin{array}{l}\text { PREFEITURA } \\
\text { MUNICIPAL DE } \\
\text { BOTUCATU }\end{array}$ & $\begin{array}{l}\text { PREFEITURA } \\
\text { MUNICIPAL }\end{array}$ & Não iniciado & - & $142.500,00$ & $7.500,00$ & $150.000,00$ & Município & Não reemb. & $\begin{array}{l}\text { Conservação do } \\
\text { Solo - (metros } \\
\text { lineares) }\end{array}$ & 5000 & $\mathrm{PDC} 03$ & 6 & $\begin{array}{c}\text { A JUSTIFICATIVA DO PLANO DE } \\
\text { RECUPERAçãO AMBIENTAL DA áREA } \\
\text { DEGRADADA DA MICROBACIA DO } \\
\text { CóRREGO ARACATU }\end{array}$ \\
\hline $\begin{array}{c}\text { SERVIÇO } \\
\text { AUTÔNOMO } \\
\text { MUNICIPALDE } \\
\text { ÁGUA EESGOTO DE } \\
\text { TIETÊ-SAMAE }\end{array}$ & $\begin{array}{l}\text { SANEAMENTO } \\
\text { PÚBLICO }\end{array}$ & Cancelado & 05/05/2017 & 0 & 0 & 0 & Município & Não reemb. & $\begin{array}{l}\text { Coleta e } \\
\text { Tratamento de } \\
\text { Esgotos } \\
\text { (habitantes) }\end{array}$ & 36835 & $\mathrm{PDC} 03$ & 12 & $\begin{array}{l}\text { ENCAMINHAR OS EFLUENTES PARA O } \\
\text { CORRETO TRATAMENTO, } \\
\text { CONTRIBUINDO PARA A MELHORIA } \\
\text { DOS RECURSOS HIDRICO }\end{array}$ \\
\hline $\begin{array}{l}\text { DEPARTAMENTO DE } \\
\text { AGUAS E ENERGIA } \\
\text { ELETRICA - DAEE }\end{array}$ & $\begin{array}{l}\text { AUTARQUIA } \\
\text { PÚBLICA } \\
\text { ESTADUAL }\end{array}$ & Não iniciado & & $2.170 .000,00$ & $230.000,00$ & $2.400 .000,00$ & Estado & Não reemb. & $\begin{array}{l}\text { Estudos/Projetos } \\
\quad \text { (contratos) }\end{array}$ & 1850000 & PDC01 & 12 & $\begin{array}{l}\text { MODERNIZAÇÃO DAS REDE } \\
\text { HIDROLÓGICA BÁSICA DA BACIA DO } \\
\text { SOROCABA EMÉDIO TIETÉ; }\end{array}$ \\
\hline $\begin{array}{l}\text { IPESA - INSTITUTO } \\
\text { DE PROJETOS E } \\
\text { PESQUISAS } \\
\text { SOCIOAMBIENTAIS }\end{array}$ & MEIO AMBIENTE & Cancelado & $05 / 05 / 2017$ & 0 & 0 & 0 & Sociedade Civil & Não reemb. & $\begin{array}{l}\text { Estudos/Projetos } \\
\text { (contratos) }\end{array}$ & 800000 & $\mathrm{PDC} 04$ & 24 & $\begin{array}{l}\text { CRIAR, MANTER EDIVULGAR BANCO } \\
\text { DE ÁREAS PARA RECUPERAçã̃O } \\
\text { FLORESTAL DA ZONA DE } \\
\text { CONSERVAção DA BIODIVE }\end{array}$ \\
\hline $\begin{array}{l}\text { FUNDAC̄̃̃O DE } \\
\text { ESTUDOS E } \\
\text { PESQUISAS } \\
\text { AGRÍCOLAS E } \\
\text { FLORESTAIS }\end{array}$ & $\begin{array}{c}\text { PESQUISA E } \\
\text { DESENVOLVIMENTO } \\
\text { EXPERIMENTAL EM } \\
\text { CIÊNCIAS FÍSICAS E } \\
\text { NATURAIS }\end{array}$ & Não iniciado & - & $407.800,00$ & 0 & $407.800,00$ & Sociedade Civil & Não reemb. & $\begin{array}{l}\text { Estudos/Projetos } \\
\text { (contratos) }\end{array}$ & 1811904 & PDC01 & 12 & $\begin{array}{l}\text { DESENVOLVER ESTUDOS PARA } \\
\text { SUBSIDIAR A IMPALNATAÇãO DE UM } \\
\text { SISTEMA GEORREFERENCIADO DAS } \\
\text { INFORMAçõES GEO }\end{array}$ \\
\hline $\begin{array}{l}\text { UNIVERSIDADE } \\
\text { ESTADUAL } \\
\text { PREFETUURA }\end{array}$ & $\begin{array}{l}\text { UNIVERSIDADE } \\
\text { PÚBLICA }\end{array}$ & Não iniciado & - & $224.716,95$ & $24.968,55$ & $249.685,50$ & Estado & Não reemb. & $\begin{array}{l}\text { Estudos/Projetos } \\
\text { (contratos) }\end{array}$ & 50000 & PDC01 & 12 & $\begin{array}{l}\text { GERAção DE DIVERSAS INFORMAç̄̄ES } \\
\text { DE ORDEM ESPACIAL, SOCIALE } \\
\text { OS CóRREGOS URBANOS DEVIDO à }\end{array}$ \\
\hline $\begin{array}{l}\text { PREFEITURA } \\
\text { MUNICIPALDE } \\
\text { TATUÍ }\end{array}$ & $\begin{array}{l}\text { PREFEITURA } \\
\text { MUNICIPAL }\end{array}$ & Cancelado & $11 / 01 / 2017$ & 0 & 0 & 0 & Município & Não reemb. & Outros (contratos) & 117000 & $\mathrm{PDC} 03$ & 7 & $\begin{array}{l}\text { GRANDE PRESSãO ANTRóPICA SOFRE } \\
\text { NECESSTTAM DE MEDIDAS DE } \\
\text { CONSERVAçãO EFI }\end{array}$ \\
\hline $\begin{array}{l}\text { MUNICIPIO DE } \\
\text { SALTO DE } \\
\text { PIRAPORA }\end{array}$ & $\begin{array}{l}\text { ADMINISTRAÇ̃̃o } \\
\text { PÚBLICA } \\
\text { MUNICIPAL }\end{array}$ & Não iniciado & & $1.306 .148,17$ & $230.496,72$ & $1.536 .644,89$ & Município & Não reemb. & $\begin{array}{l}\text { Trat. e Disposicicão } \\
\text { de Lixo - Obras } \\
\text { (habitantes) }\end{array}$ & 40132 & $\mathrm{PDCO}_{3}$ & 37 & $\begin{array}{l}\text { REALIZAR A DESTINAÇ̃̃O DOS } \\
\text { RESÍIUOS SÓLIDOS URBANOS } \\
\text { COLETADOS NO MUNIĆPIO DE SALTO } \\
\text { DE PIRAPORA DEFO }\end{array}$ \\
\hline $\begin{array}{l}\text { PREFEITURA } \\
\text { MUNICIPALDE } \\
\text { SOROCABA }\end{array}$ & PREFEITURA & Não iniciado & - & $345.167,88$ & $47.104,08$ & 392.271,96 & Sociedade Civil & Não reemb. & $\begin{array}{l}\text { Recomposição de } \\
\text { Mata Ciliar } \\
\text { (hectares) }\end{array}$ & 630000 & PDC04 & 36 & $\begin{array}{l}\text { RESTAURAR A VEGETAÇãO NATURAL } \\
\text { DA MICROBACIA LOCALIZADA NO } \\
\text { PARQUE MUNICIPALDA CACHOEIRA, } \\
\text { MUNICIPIO D }\end{array}$ \\
\hline $\begin{array}{l}\text { PREFEITURA } \\
\text { MUNICIPALDE } \\
\text { SOROCABA }\end{array}$ & PREFEITURA & Não iniciado & - & $161.000,28$ & $18.261,00$ & $179.261,28$ & Sociedade Civil & Não reemb. & $\begin{array}{l}\text { Estudos/Projetos } \\
\text { (contratos) }\end{array}$ & 630000 & PDC01 & 8 & $\begin{array}{c}\text { O PROJETO VISA IDENTIFICAR A } \\
\text { SITUAçãO E PROPOR Aç̃̃ES PARA A } \\
\text { PROTEçãO DAS NASCENTES DO } \\
\text { MUNICIPIO. }\end{array}$ \\
\hline $\begin{array}{l}\text { PREFEITURA } \\
\text { MUNICIPALDE } \\
\text { LARANJAL } \\
\text { PAULISTA }\end{array}$ & $\begin{array}{l}\text { PREFEITURA } \\
\text { MUNICIPAL }\end{array}$ & Cancelado & $11 / 01 / 2017$ & 0 & 0 & 0 & Município & Não reemb. & $\begin{array}{l}\text { Conservação do } \\
\text { Solo - (metros } \\
\text { lineares) }\end{array}$ & 3000 & PDC08 & 9 & $\begin{array}{c}\text { CONTENção DA MARGEM DO } \\
\text { RIBEIRãO LARANJAL, POIS AS CASAS } \\
\text { PROXIMAS A ESSES RIBEIRão ESTãO } \\
\text { EM UMA áREA }\end{array}$ \\
\hline
\end{tabular}




\begin{tabular}{|c|c|c|c|c|c|c|c|c|c|c|c|c|c|}
\hline Nome do interess ado & $\begin{array}{l}\text { Atividade principal do } \\
\text { interessado }\end{array}$ & $\begin{array}{c}\text { Situacão do } \\
\text { empreendimento }\end{array}$ & $\begin{array}{l}\text { Data de } \\
\text { conclusão }\end{array}$ & Valor aprovado & $\begin{array}{c}\text { Valor de } \\
\text { contrapartida }\end{array}$ & Valor total & $\begin{array}{l}\text { Segmento do } \\
\text { interessado }\end{array}$ & Modalidade & $\begin{array}{l}\text { Benefíicio: } \\
\text { indicador }\end{array}$ & $\begin{array}{l}\text { População } \\
\text { beneficiada }\end{array}$ & PDC: sigla & $\begin{array}{l}\text { Tempo de } \\
\text { execução } \\
\text { (meses) }\end{array}$ & Descrição \\
\hline $\begin{array}{l}\text { CONSÓRCIO DE } \\
\text { ESTUDOS, } \\
\text { RECUPERAÇÃO E } \\
\text { DESENVOLVIMENTO } \\
\text { DA BACIA DOS RIOS } \\
\text { SOROCABA EMÉDIO } \\
\text { TIETÊ- CERISO }\end{array}$ & $\begin{array}{c}\text { CONSÓRCIO } \\
\text { INTERMUNICIPAL }\end{array}$ & Cancelado & $11 / 01 / 2017$ & 0 & 0 & 0 & Sociedade Civil & Não reemb. & $\begin{array}{l}\text { Estudos/Projetos } \\
\text { (contratos) }\end{array}$ & 1700000 & $\mathrm{PDCO} 3$ & 12 & $\begin{array}{l}\text { OBJETIVO: DIAGNóSTICO DA } \\
\text { SITUAçãO DOS RESiDUOS SóLIDOS NA } \\
\text { UGRHI-10 EESTIMATIVA DE } \\
\text { DEMANDAS FUTURAS }\end{array}$ \\
\hline $\begin{array}{l}\text { CONSÓRCIO DE } \\
\text { ESTUDOS, } \\
\text { RECUPERAÇÃO E } \\
\text { DESENVOLVIMENTO } \\
\text { DA BACIA DOS RIOS } \\
\text { SOROCABA EMÉDIO } \\
\text { TIETÊ- CERISO }\end{array}$ & $\begin{array}{c}\text { CONSÓRCIO } \\
\text { INTERMUNICIPAL }\end{array}$ & Concluído & 29/08/2005 & $58.648,26$ & 0 & $58.648,26$ & Sociedade Civil & Não reemb. & $\begin{array}{l}\text { Educação } \\
\text { Ambiental } \\
\text { (contratos) }\end{array}$ & 2000000 & PDC01 & 5 & $\begin{array}{l}\text { FACILITAR ACESSO ÀS INFORMAÇõES } \\
\text { DO COMITÊ }\end{array}$ \\
\hline $\begin{array}{l}\text { CONSÓRCIO DE } \\
\text { ESTUDOS, } \\
\text { RECUPERACCÃOE } \\
\text { DESENVOLVIMENTO } \\
\text { DA BACIA DOS RIOS } \\
\text { SOROCABA EMÉDIO } \\
\text { TIETÊ- CERISO }\end{array}$ & $\begin{array}{c}\text { CONSÓRCIO } \\
\text { INTERMUNICIPAL }\end{array}$ & Concluído & 29/11/2006 & $150.000,00$ & 0 & $150.000,00$ & Sociedade Civil & Não reemb. & $\begin{array}{l}\text { Planej. e Gerenc. } \\
\text { dos Recs. Hídricos } \\
\text { (contratos) }\end{array}$ & 2000000 & PDC01 & 12 & $\begin{array}{l}\text { CADASTRAMENTO DE IRRIGANTES } \\
\text { NA BACIA HIDROGRÁFICA DA UHE DE } \\
\text { ITUPARARANGA }\end{array}$ \\
\hline $\begin{array}{c}\text { UNESP - } \\
\text { UNIVERSIDADE } \\
\text { ESTADUAL } \\
\text { PAUUISTA JÚLIO DE } \\
\text { MESQUTA FILHO }\end{array}$ & $\begin{array}{c}\text { INSTITUIÇÃO DE } \\
\text { ENSINO SUPERIOR }\end{array}$ & Cancelado & 18/01/2005 & $70.488,80$ & $43.109,10$ & $113.597,90$ & Estado & Não reemb. & $\begin{array}{l}\text { Estudos/Projetos } \\
\text { (contratos) }\end{array}$ & 50000 & PDC01 & 12 & $\begin{array}{l}\text { CARACTERIZAÇÃO AMBIENTAL DA } \\
\text { PARTE INICIAL DA BACIA DO RIO } \\
\text { CAPIVARA, NO MUNCIIPIO DE } \\
\text { BOTUCATU, COM LE }\end{array}$ \\
\hline $\begin{array}{l}\text { COMPANHIA DE } \\
\text { SANEAMENTO } \\
\text { BÁSICO DO ESTADO } \\
\text { DE SÃO PAULO - } \\
\text { SABESP }\end{array}$ & $\begin{array}{l}\text { SANEAMENTO } \\
\text { BÁSICO }\end{array}$ & Concluído & 19/10/2009 & $179.702,55$ & $136.119,16$ & $315.821,71$ & Estado & Reembolsável & $\begin{array}{l}\text { Estudos/Projetos } \\
\text { (contratos) }\end{array}$ & 1967 & $\mathrm{PDC}_{3}$ & 8 & $\begin{array}{c}\text { IMPLANTAÇ̃̃O DO SISTEMA DE } \\
\text { AFASTAMENTO ETRATAMENTO DE } \\
\text { ESGOTOS COM MELHORIA SANITÁRIA } \\
\text { EAMBIENTALDA }\end{array}$ \\
\hline $\begin{array}{l}\text { SERVICCO } \\
\text { AUTÔNOMO DE } \\
\text { ÁGUA EESGOTO DE } \\
\text { ITU }\end{array}$ & $\begin{array}{l}\text { PREFEITURA } \\
\text { MUNICIPAL }\end{array}$ & Concluído & $24 / 10 / 2008$ & $103.500,00$ & $34.225,00$ & $137.725,00$ & Município & Não reemb. & $\begin{array}{l}\text { Estudos/Projetos } \\
\text { (contratos) }\end{array}$ & 18000 & $\mathrm{PDC0} 3$ & 5 & $\begin{array}{c}\text { MELHORAR AS CONDIÇÕES } \\
\text { SAITÁRIAS DA BACIA COM O } \\
\text { AFASTAMENTO DOS EFLUENTES } \\
\text { DOMÉSTICOS ATUALMENTELANÇA }\end{array}$ \\
\hline $\begin{array}{l}\text { PREFEITURA } \\
\text { MUNICIPALDE } \\
\text { BOTUCATU }\end{array}$ & $\begin{array}{l}\text { PREFEITURA } \\
\text { MUNICIPAL }\end{array}$ & Cancelado & $14 / 08 / 2009$ & $179.853,60$ & $96.132,00$ & $275.985,60$ & Município & Não reemb. & $\begin{array}{l}\text { Trat. e Disposição } \\
\text { de Lixo - Obras } \\
\text { (habitantes) } \\
\text { Coleta e } \\
\text { Tratamento de } \\
\text { Esgotos } \\
\text { (habitantes) }\end{array}$ & 117000 & $\mathrm{PDC}_{3}$ & 12 & $\begin{array}{l}\text { IMPLANTAÇ̃̃O DE NOVA TRINCHEIRA } \\
\text { PARA RECEBIMENTO DE RESÍDUOS } \\
\text { DOMICIUARES NO ATUAL ATERRO } \\
\text { SANITÁRIO M } \\
\text { SUPRESSÃO DO ATUAL } \\
\text { LANÇAMENTO DE EFLUENTES EM } \\
\text { CÓRREGO AO LADO DA ROD. } \\
\text { MARECHAL RONDON E SEU } \\
\text { ENCAMINH }\end{array}$ \\
\hline
\end{tabular}




\begin{tabular}{|c|c|c|c|c|c|c|c|c|c|c|c|c|c|}
\hline Nome do interessado & $\begin{array}{l}\text { Atividade principal do } \\
\text { interessado }\end{array}$ & $\begin{array}{l}\text { Situação do } \\
\text { empreendimento }\end{array}$ & $\begin{array}{l}\text { Data de } \\
\text { conclusão }\end{array}$ & Valor aprovado & $\begin{array}{c}\text { Valor de } \\
\text { contrapartida }\end{array}$ & Valor total & $\begin{array}{l}\text { Segmento do } \\
\text { interessado }\end{array}$ & Modalidade & $\begin{array}{l}\text { Benefício: } \\
\text { indicador }\end{array}$ & $\begin{array}{c}\text { Populacãa } \\
\text { beneficiada }\end{array}$ & PDC: sigla & $\begin{array}{l}\text { Tempo de } \\
\text { execução } \\
\text { (meses) }\end{array}$ & Descrição \\
\hline $\begin{array}{l}\text { PREFEITURA } \\
\text { MUNICIALALDA } \\
\text { ESTÂNCIA } \\
\text { TURíSTICA DE } \\
\text { IBIÚNA }\end{array}$ & $\begin{array}{l}\text { PREFEITURA } \\
\text { MUNICIPAL }\end{array}$ & Concluído & $31 / 10 / 2011$ & $70.544,00$ & $14.775,00$ & $85.319,00$ & Município & Não reemb. & $\begin{array}{l}\text { Trat. e Disposição } \\
\text { de Lixo - Obras } \\
\text { (habitantes) }\end{array}$ & 10000 & PDC03 & 3 & $\begin{array}{c}\text { RECUPERAÇÃO AMBIENTAL DA ÁREA } \\
\text { DEGRADADA PELO ANTIGO LIXÃO } \\
\text { MUNICIPAL. }\end{array}$ \\
\hline $\begin{array}{l}\text { PREFEITURA } \\
\text { MUNICIPALDE } \\
\text { PORTO FELIZ }\end{array}$ & $\begin{array}{l}\text { PREFEITURA } \\
\text { MUNICIPAL }\end{array}$ & Concluído & 04/03/2010 & $174.976,08$ & $43.744,02$ & $218.720,10$ & Município & Não reemb. & $\begin{array}{l}\text { Educação } \\
\text { Ambiental } \\
\text { (contratos) }\end{array}$ & 50000 & PDC05 & 10 & $\begin{array}{l}\text { ELABORAR OZONEAMENTO } \\
\text { AMBIIENTAL DO MUNICIPIO } \\
\text { COMPAIIVEL COM A POLIITICA DE } \\
\text { RECURSOS HÍDRICOS DA BACIA }\end{array}$ \\
\hline $\begin{array}{c}\text { SERVIÇO } \\
\text { AUTÔNOMO DE } \\
\text { ÁGUA E ESGOTO DE } \\
\text { VOTORANTIM - } \\
\text { SAAE }\end{array}$ & $\begin{array}{l}\text { PREFEITURA } \\
\text { MUNICIPAL }\end{array}$ & Concluído & $31 / 10 / 2008$ & $137.512,93$ & $59.344,80$ & $196.857,73$ & Município & Não reemb. & $\begin{array}{l}\text { Abastecimento de } \\
\text { Água (habitantes) }\end{array}$ & 103722 & PDC05 & 6 & $\begin{array}{c}\text { EXECUÇ̃̃O DE ATIVIDADES DE } \\
\text { PLANEJAMENTO E IMPLANTAÇ̃̃̃O DE } \\
\text { AÇÕES PREVENTIVAS E CORRETIVAS } \\
\text { VISANDO A RED }\end{array}$ \\
\hline $\begin{array}{l}\text { PREFEITURA } \\
\text { MUNIIIPALDE } \\
\text { IPERÓ }\end{array}$ & $\begin{array}{l}\text { PREFEITURA } \\
\text { MUNICIPAL }\end{array}$ & Concluído & 07/08/2009 & $168.667,52$ & $49.652,76$ & $218.320,28$ & Município & Não reemb. & $\begin{array}{l}\text { Coleta e } \\
\text { Tratamento de } \\
\text { Esgotos } \\
\text { (habitantes) }\end{array}$ & 17230 & $\mathrm{PDC} 03$ & 5 & $\begin{array}{c}\text { AFASTAMENTO PARA TRATAMENTO } \\
\text { DOS ESGOTOS GERADOS NO PRONTO } \\
\text { ATENDIMENTO E MATERNIDADE } \\
\text { IPERÓ. }\end{array}$ \\
\hline $\begin{array}{l}\text { CONSÓRCIO DE } \\
\text { ESTUDOS, } \\
\text { RECUPERAÇÃO E } \\
\text { DESENVOLVIMENTO } \\
\text { DA BACIA DOS RIOS } \\
\text { SOROCABA E MÉDIO } \\
\text { TIETÊ- CERISO }\end{array}$ & $\begin{array}{l}\text { CONSÓRCIO } \\
\text { INTERMUNICIPAL }\end{array}$ & Concluído & 09/04/2008 & $161.209,17$ & 0 & $161.209,17$ & Sociedade Civil & Não reemb. & $\begin{array}{l}\text { Educação } \\
\text { Ambiental } \\
\text { (contratos) }\end{array}$ & 2000000 & PDC01 & 12 & $\begin{array}{l}\text { ATUALIZAÇ̃̃̃O E MODERNIZAÇ̃̃̃O } \\
\text { DA SECRETARIA EXECUTIVA DO } \\
\text { CBH/SMT. }\end{array}$ \\
\hline $\begin{array}{l}\text { CONSÓRCIO DE } \\
\text { ESTUDOS, } \\
\text { RECUPERAÇÃ̃OE } \\
\text { DESENVOLVIMENTO } \\
\text { DA BACIA DOS RIOS } \\
\text { SOROCABA EMÉDIO } \\
\text { TIETÊ- CERISO }\end{array}$ & $\begin{array}{l}\text { CONSÓRCIO } \\
\text { INTERMUNICIPAL }\end{array}$ & Concluído & 08/02/2006 & $101.700,00$ & 0 & $101.700,00$ & Sociedade Civil & Não reemb. & $\begin{array}{l}\text { Educação } \\
\text { Ambiental } \\
\text { (contratos) }\end{array}$ & 2000000 & PDC01 & 12 & $\begin{array}{l}\text { PLANO DE COMUNICAÇ̃̃O PARA O } \\
\text { CBH-SMT - MELHORIA EAMPIAÇÃO } \\
\text { DOS ACESSOS AO CBH-SMT }\end{array}$ \\
\hline $\begin{array}{l}\text { CONSÓRCIO DE } \\
\text { ESTUDOS, } \\
\text { RECUPERAÇÃ̃ E } \\
\text { DESENVOLVIMENTO }\end{array}$ & $\begin{array}{l}\text { CONSÓRCIO } \\
\text { INTERMUNICIPAL }\end{array}$ & Concluído & 16/06/2008 & $179.760,00$ & $94.980,80$ & $274.740,80$ & Sociedade Civil & Não reemb. & $\begin{array}{l}\text { Abastecimento de } \\
\text { Água (habitantes) }\end{array}$ & 154637 & PDC05 & 6 & $\begin{array}{c}\text { PESQUISA E CONSERTO DE } \\
\text { VAZAMENTOS LOZALIZADOS PARA } \\
\text { REDUÇÃO DO ÍNDICE DE PERDAS } \\
\text { ATUALMENTE VERIFICADO }\end{array}$ \\
\hline $\begin{array}{l}\text { PREFEITURA } \\
\text { MUNICIPAL DE } \\
\text { ANHEMBI }\end{array}$ & $\begin{array}{l}\text { PREFEITURA } \\
\text { MUNICIPAL }\end{array}$ & Concluído & 18/08/2009 & $139.858,16$ & $34.964,54$ & $174.822,70$ & Município & Não reemb. & $\begin{array}{l}\text { Coleta e } \\
\text { Tratamento de } \\
\text { Esgotos } \\
\text { (habitantes) }\end{array}$ & 2615 & PDC03 & 8 & $\begin{array}{l}\text { PROJETO EXECUTIVO PARA FUTURA } \\
\text { IMPLANTAÇÃO DE ETE. }\end{array}$ \\
\hline $\begin{array}{l}\text { PREFEITURA } \\
\text { MUNICIPALDE } \\
\text { VARGEM GRANDE } \\
\text { PAULISTA }\end{array}$ & $\begin{array}{l}\text { PREFEITURA } \\
\text { MUNICIPAL }\end{array}$ & Concluído & 18/06/2009 & $158.768,00$ & $156.211,00$ & $314.979,00$ & Município & Não reemb. & $\begin{array}{l}\text { Trat. e Disposiç̃ão } \\
\text { de Lixo - Obras } \\
\text { (habitantes) }\end{array}$ & 41309 & $\mathrm{PDC} 03$ & 6 & $\begin{array}{c}\text { RECUPERAÇ̃̃O DE ÁREA } \\
\text { DERADADA POR DEPOSIÇÃO O DE } \\
\text { RESÍDUOS SÓLIDOS URBANOS. }\end{array}$ \\
\hline $\begin{array}{c}\text { PREFEITURA } \\
\text { MUNICIPAL DE } \\
\text { CAPELA DO ALTO }\end{array}$ & $\begin{array}{l}\text { PREFEITURA } \\
\text { MUNICIPAL }\end{array}$ & Concluído & $03 / 11 / 2008$ & $110.810,01$ & $47.416,51$ & $158.226,52$ & Município & Não reemb. & $\begin{array}{l}\text { Coleta e } \\
\text { Tratamento de } \\
\text { Esgotos } \\
\text { (habitantes) }\end{array}$ & 800 & $\mathrm{PDC} 03$ & 6 & $\begin{array}{l}\text { COLETA E TRATAMENTO DE ESGOTOS } \\
\text { DO BAIRRO CARCADINHO. }\end{array}$ \\
\hline $\begin{array}{l}\text { ASSOCIAÇ̃̃̃ } \\
\text { ECOAR FLORESTAL }\end{array}$ & $\begin{array}{l}\text { REALZZAÇAO DE } \\
\text { PROETOS } \\
\text { SOCIOAMBIENTAIS }\end{array}$ & Concluído & 05/09/2011 & $35.001,00$ & $12.771,20$ & $47.772,20$ & Sociedade Civil & Não reemb. & $\begin{array}{l}\text { Estudos/Projetos } \\
\text { (contratos) }\end{array}$ & 100 & PDC09 & 8 & $\begin{array}{l}\text { MELHORAR A QUALIDADE DAS } \\
\text { RESTAURAÇŌES FLORESTAIS. }\end{array}$ \\
\hline
\end{tabular}




\begin{tabular}{|c|c|c|c|c|c|c|c|c|c|c|c|c|c|}
\hline Nome do interessado & $\begin{array}{l}\text { Atividade principal do } \\
\text { interessado }\end{array}$ & $\begin{array}{l}\text { Situação do } \\
\text { empreendimento }\end{array}$ & $\begin{array}{l}\text { Data de } \\
\text { conclusão }\end{array}$ & Valor aprovado & $\begin{array}{c}\text { Valor de } \\
\text { contrapartida }\end{array}$ & Valor total & $\begin{array}{l}\text { Segmento do } \\
\text { interessado }\end{array}$ & Modal idade & $\begin{array}{l}\text { Benefício: } \\
\text { indicador }\end{array}$ & $\begin{array}{c}\text { Populacão } \\
\text { beneficiada }\end{array}$ & PDC: sigla & $\begin{array}{l}\text { Tempo de } \\
\text { execução } \\
\text { (meses) }\end{array}$ & Descrição \\
\hline $\begin{array}{l}\text { PREFEITURA } \\
\text { MUNIIIPLDE } \\
\text { ALAMBARÍ }\end{array}$ & $\begin{array}{l}\text { PREFEITURA } \\
\text { MUNICIPAL }\end{array}$ & Concluído & $31 / 07 / 2007$ & $106.903,06$ & $28.417,31$ & $135.320,37$ & Município & Não reemb. & $\begin{array}{l}\text { Galerias de Águas } \\
\text { Pluviais (metros } \\
\text { lineares) }\end{array}$ & 1500 & PDC09 & 3 & $\begin{array}{l}\text { CONTROLE DE ASSOREAMENTO E } \\
\text { ROSÃAO URBANA. }\end{array}$ \\
\hline $\begin{array}{l}\text { PREFEITURA } \\
\text { MUNICIPALDE } \\
\text { TATUÍ }\end{array}$ & $\begin{array}{l}\text { PREFEITURA } \\
\text { MUNICIPAL }\end{array}$ & Concluído & $30 / 10 / 2008$ & $128.000,00$ & $32.000,00$ & $160.000,00$ & Município & Não reemb. & $\begin{array}{l}\text { Estudos/Projetos } \\
\quad \text { (contratos) }\end{array}$ & 100000 & PDC06 & 12 & $\begin{array}{c}\text { CONTRATAÇ̃̃O DEEMPRESA } \\
\text { ESPECIALIZADA PARA EFETUAR O } \\
\text { ADASTRAMENTO DE RRRGANTES NA } \\
\text { BACIA HIDROGRÁFICA }\end{array}$ \\
\hline $\begin{array}{c}\text { FUNDAÇ̃̃O SOS } \\
\text { MATA ATLANTICA }\end{array}$ & $\begin{array}{l}\text { DEFESA DO MEIO } \\
\text { AMBIENTE E } \\
\text { RECURSOS } \\
\text { HÍDRICOS }\end{array}$ & Concluído & $04 / 06 / 2013$ & $125.387,60$ & $31.469,00$ & $156.856,60$ & Sociedade Civil & Não reemb. & $\begin{array}{l}\text { Educação } \\
\text { Ambiental } \\
\text { (contratos) }\end{array}$ & 2500 & PDC01 & 12 & $\begin{array}{l}\text { PROGRAMA DE EDUCAÇÃO } \\
\text { AMBIENTAL EENGAJAMENTO } \\
\text { SOCIAL. }\end{array}$ \\
\hline $\begin{array}{c}\text { SOS } \\
\text { ITUPARARANGA - } \\
\text { ORGANIZAČ̃̃O DA } \\
\text { SOCIEDADECIVIL DE } \\
\text { INTERESSE PÚBLICO }\end{array}$ & $\begin{array}{l}\text { PROTEÇÃO DOS } \\
\text { RECURSOS } \\
\text { HÍDRICOS E } \\
\text { PROJETOS DE } \\
\text { EDUCAÇÃO } \\
\text { AMBIENTAL }\end{array}$ & Concluído & 08/07/2009 & $49.280,00$ & $14.720,00$ & $64.000,00$ & Sociedade Civil & Não reemb. & $\begin{array}{l}\text { Educação } \\
\text { Ambiental } \\
\text { (contratos) }\end{array}$ & 5000 & PDC10 & 6 & $\begin{array}{l}\text { PRODUÇÃO DECARTILHA SOBRE A } \\
\text { APA DE ITUPARARANGA } \\
\text { ABORDANDO SESA ASPECTOS GERAIS } \\
\text { EPRINCIPAIS IMPACTO }\end{array}$ \\
\hline ASSOCIAÇÃ̃ JAPI & MEIO AMBIENTE & Concluído & 23/11/2007 & $118.663,60$ & $35.644,00$ & $154.307,60$ & Sociedade Civil & Não reemb. & $\begin{array}{l}\text { Educação } \\
\text { Ambiental } \\
\text { (contratos) }\end{array}$ & 2036 & PDC01 & 5 & $\begin{array}{l}\text { PRESERVACC̃̃O DA QUALIDADE DE } \\
\text { VIDA PARA OS HABITANTE DA } \\
\text { REGIIÃO DE ENTORNO DA GRANDE } \\
\text { SÃO PAULO }\end{array}$ \\
\hline $\begin{array}{l}\text { CONSÓRCIO DE } \\
\text { ESTUDOS, } \\
\text { RECUPERAÇÃO E } \\
\text { DESENVOLVIMENTO } \\
\text { DA BACIA DOS RIOS } \\
\text { SOROCABA E MÉDIO } \\
\text { TIETEE - CERISO }\end{array}$ & $\begin{array}{l}\text { CONSÓRCIO } \\
\text { INTERMUNICIPAL }\end{array}$ & Cancelado & 26/04/2005 & $99.410,00$ & 0 & $99.410,00$ & Sociedade Civil & Não reemb. & Outros (contratos) & 2000000 & PDC01 & 12 & $\begin{array}{c}\text { CAPACITAÇÃO PARA } \\
\text { GERENCIAMENTO DOS RECURSOS } \\
\text { HÍDRICOS }\end{array}$ \\
\hline $\begin{array}{c}\text { UNESP- } \\
\text { UNIVERSIDADE } \\
\text { ESTADUAL } \\
\text { PAUUISTA JÚLIO DE } \\
\text { MESQUITA FILHO }\end{array}$ & $\begin{array}{l}\text { INSTITUICCÃO DE } \\
\text { ENSINO SUPERIOR }\end{array}$ & Concluído & 13/02/2014 & $39.150,00$ & $36.000,00$ & $75.150,00$ & Estado & Não reemb. & $\begin{array}{l}\text { Estudos/Projetos } \\
\quad \text { (contratos) }\end{array}$ & 100000 & PDC01 & 12 & $\begin{array}{l}\text { CARACTERIZAČ̃̃ O DA QUALIDADE } \\
\text { DA ÁGUA SUPERFIIIALE } \\
\text { MONITORAMENTO DA VAZÃO NA } \\
\text { BACIA DO RIO SOROCABA/PI }\end{array}$ \\
\hline $\begin{array}{l}\text { ASSOCIACCÃO } \\
\text { ECOLÓGICA ICATU }\end{array}$ & $\begin{array}{l}\text { EDUCAÇÃO } \\
\text { AMBIENTAL }\end{array}$ & Cancelado & 17/06/2010 & $89.000,00$ & $24.000,00$ & $113.000,00$ & Sociedade Civil & Não reemb. & $\begin{array}{c}\text { Estudos//Projetos } \\
\text { (contratos) }\end{array}$ & 100000 & PDC09 & 12 & $\begin{array}{l}\text { SUBSIDIAR A ADOÇ̃̃O DE POLĹTICA } \\
\text { VOLTADA A RESTAURAÇ̃̃O } \\
\text { FLORESTAL CLIAR PARA A } \\
\text { PROTEÇÃ̃ O DE MANANCIAIS. }\end{array}$ \\
\hline $\begin{array}{l}\text { ASSOCIAÇ̃̃o } \\
\text { JORNADA } \\
\text { ECOLÓGICA - AJE }\end{array}$ & $\begin{array}{l}\text { PROTEÇ̃̃O AO } \\
\text { MEIO AMBIENTE }\end{array}$ & Cancelado & 20/03/2006 & 0 & 0 & 0 & Sociedade Civil & Não reemb. & $\begin{array}{l}\text { Estudos/Projetos } \\
\text { (contratos) }\end{array}$ & 10000 & PDC01 & 12 & $\begin{array}{l}\text { PESQUISA, ESTUDO E ANÁLISE DA } \\
\text { LEGISLAÇÃO AMBIENTAL DOS } 34 \\
\text { MUNICIPIOS COMPONENTE DO } \\
\text { CBH/SMT, EPROPOS }\end{array}$ \\
\hline $\begin{array}{l}\text { FUNDAÇ̃̃o DE } \\
\text { ESTUDOS E } \\
\text { PESQUISAS } \\
\text { AGRÍCOLAS E } \\
\text { FLORESTAIS }\end{array}$ & $\begin{array}{c}\text { PESQUISA E } \\
\text { DESENVOLVIMENTO } \\
\text { EXPERIMENTAL EM } \\
\text { CIÊNCIAS FísICAS E } \\
\quad \text { NATURAIS }\end{array}$ & Concluído & 09/06/2011 & $149.436,92$ & $42.147,34$ & $191.584,26$ & Sociedade Civil & Não reemb. & $\begin{array}{l}\text { Recomposição de } \\
\text { Mata Ciliar } \\
\text { (hectares) }\end{array}$ & 2000000 & PDC09 & 24 & $\begin{array}{l}\text { IMPLANTACCÃO DE POMARES DE } \\
\text { SEMENTES ARBÓREAS NATIVAS }\end{array}$ \\
\hline $\begin{array}{c}\text { INSTITUTO } \\
\text { ARUANDISTA DE } \\
\text { PESQUSAS E } \\
\text { DESENVOLVIMENTO } \\
\text { PREFEITURA }\end{array}$ & $\begin{array}{l}\text { ONGINST. DE } \\
\text { PESQUISAS E } \\
\text { DESENV. - MEIO } \\
\text { AMBIENTE- } \\
\text { DESENV. } \\
\text { SUSTENTÁVEL }\end{array}$ & Concluído & $04 / 11 / 2005$ & $78.238,00$ & $19.579,92$ & $97.817,92$ & Sociedade Civil & Não reemb. & $\begin{array}{l}\text { Educação } \\
\text { Ambiental } \\
\text { (contratos) }\end{array}$ & 288000 & PDC12 & 12 & $\begin{array}{l}\text { EDUCACCÃO AMBIENTALE } \\
\text { TREINAMENTO PARA PROJETISTAS, } \\
\text { GERENCIADORES, GESTORES E } \\
\text { COMUNICADORES AMBIENTAI }\end{array}$ \\
\hline $\begin{array}{l}\text { MUNIIIPAL DA } \\
\text { ESTÂNCIA } \\
\text { TURÍSTICA DE } \\
\text { IBIÚNA }\end{array}$ & $\begin{array}{l}\text { PREFEITURA } \\
\text { MUNICIPAL }\end{array}$ & Concluído & 07/08/2009 & $150.000,00$ & $199.278,63$ & $349.278,63$ & Município & Não reemb. & $\begin{array}{l}\text { Trat. e Disposicicão } \\
\text { de Lixo - Obras } \\
\text { (habitantes) }\end{array}$ & 31970 & $\mathrm{PDC} 03$ & 8 & $\begin{array}{l}\text { IMPLANTACCÃO DA PRIMEIRA FASE } \\
\text { DO ATERRO SANITÁRIO DE IBIÚNA }\end{array}$ \\
\hline $\begin{array}{l}\text { PREFEITURA } \\
\text { MUNICIPALDE } \\
\text { MAIRINQUE }\end{array}$ & $\begin{array}{l}\text { PREFEITURA } \\
\text { MUNICIPAL }\end{array}$ & Cancelado & 16/01/2004 & 0 & 0 & 0 & Município & Não reemb. & $\begin{array}{l}\text { Galerias de Águas } \\
\text { Pluviais (metros } \\
\text { lineares) }\end{array}$ & 300 & PDC09 & 12 & $\begin{array}{l}\text { AMPLIAÇ̃̃O DA CAPTAÇ̃̃O DE } \\
\text { ÁGUAS PLUVIAIS }\end{array}$ \\
\hline
\end{tabular}




\begin{tabular}{|c|c|c|c|c|c|c|c|c|c|c|c|c|c|}
\hline Nome do interessado & $\begin{array}{l}\text { Atividade principal do } \\
\text { interessado }\end{array}$ & $\begin{array}{c}\text { Situação do } \\
\text { emprendimento }\end{array}$ & $\begin{array}{c}\text { Data de } \\
\text { conclusão }\end{array}$ & Valor aprovado & $\begin{array}{c}\text { Valor de } \\
\text { contrapartida }\end{array}$ & Valor total & $\begin{array}{l}\text { Segmento do } \\
\text { interessado }\end{array}$ & Modalidade & $\begin{array}{l}\text { Benefício: } \\
\text { indicador }\end{array}$ & $\begin{array}{c}\text { População } \\
\text { beneficiada }\end{array}$ & PDC: sigla & $\begin{array}{c}\text { Tempo de } \\
\text { execução } \\
\text { (meses) }\end{array}$ & Descrição \\
\hline $\begin{array}{l}\text { CONSÓRCIO DE } \\
\text { ESTUDOS, } \\
\text { RECUPERACCÃO E } \\
\text { DESENVOLVIMENTO } \\
\text { DA BACIA DOS RIOS } \\
\text { SOROCABA E MÉDIO } \\
\text { TIETÊ - CERISO }\end{array}$ & $\begin{array}{c}\text { CONSÓRCIO } \\
\text { INTERMUNICIPAL }\end{array}$ & Cancelado & $18 / 02 / 2004$ & 0 & 0 & 0 & Sociedade Civil & Não reemb. & Outros (contratos) & 0 & PDC01 & 0 & $\begin{array}{l}\text { PLANO DE USO DO SOLO NO ENTORNO } \\
\text { DE ITUPARARANGA }\end{array}$ \\
\hline $\begin{array}{l}\text { FUNDAÇÃO SOS } \\
\text { MATA ATLANTICA }\end{array}$ & $\begin{array}{l}\text { DEFESA DO MEIO } \\
\text { AMBIENTEE } \\
\text { RECURSOS } \\
\text { HÍDRICOS }\end{array}$ & Cancelado & $18 / 02 / 2004$ & 0 & 0 & 0 & Sociedade Civil & Não reemb. & Outros (contratos) & 0 & PDC01 & 0 & CONHECER PARA PRESERVAR \\
\hline $\begin{array}{l}\text { FUNDIBIOS - } \\
\text { FUND.APOIO INST. } \\
\text { DES. CIENT. E } \\
\text { TECNOLOOGICO }\end{array}$ & & Cancelado & $18 / 02 / 2004$ & 0 & 0 & 0 & & Não reemb. & Outros (contratos) & 0 & PDC01 & 0 & $\begin{array}{l}\text { PRODUCC̃̃̃ DE MATERIAL DIDÁTICO } \\
\text { SOBRE A APA BOTUCATU }\end{array}$ \\
\hline $\begin{array}{c}\text { CONSÓRCIO DE } \\
\text { ESTUDOS, } \\
\text { RECUPERAÇÃ̃O E } \\
\text { DESENVOLVIMENTO } \\
\text { DA BACIA DOS RIOS } \\
\text { SOROCABA E MÉDIO } \\
\text { TIETÊ- CERISO }\end{array}$ & $\begin{array}{c}\text { CONSÓRCIO } \\
\text { INTERMUNICIPAL }\end{array}$ & Conclú́do & $31 / 07 / 2007$ & $36.000,00$ & $9.000,00$ & $45.000,00$ & Sociedade Civil & Não reemb. & $\begin{array}{l}\text { Estudos/Projetos } \\
\text { (contratos) }\end{array}$ & 2000000 & PDC01 & 4 & $\begin{array}{l}\text { ESTUDOS PARA COMPLEMENTAÇÃO } \\
\text { DA IMPLEMENTAÇÃO DO SISTEMA DE } \\
\text { GERENCIAMENTO DE RECURSOS } \\
\text { HÍDRICOS NA BAC }\end{array}$ \\
\hline $\begin{array}{c}\text { CONSÓRCIO DE } \\
\text { ESTUDOS, } \\
\text { RECUPERAÇÃO E } \\
\text { DESENVOLVIMENTO } \\
\text { DA BACIA DOS RIOS } \\
\text { SOROCABA EMÉDIO } \\
\text { TIETÊ- CERISO }\end{array}$ & $\begin{array}{c}\text { CONSÓRCIO } \\
\text { INTERMUNICIPAL }\end{array}$ & Cancelado & $18 / 02 / 2004$ & 0 & 0 & 0 & Sociedade Civil & Não reemb. & Outros (contratos) & 0 & PDC01 & 0 & $\begin{array}{l}\text { PLANO DEBACIA -RECURSO } \\
\text { COMPLEMENTAR }\end{array}$ \\
\hline $\begin{array}{l}\text { ASSOCIAÇ̃̃o } \\
\text { ECOLÓGICA SÃO } \\
\text { FRANCISCO DE } \\
\text { ASSIS - AESFA }\end{array}$ & $\begin{array}{l}\text { CURSOS DE } \\
\text { EDUCAÇÃO } \\
\text { AMBIENTAL }\end{array}$ & Cancelado & $16 / 01 / 2004$ & 0 & 0 & 0 & Sociedade Civil & Não reemb. & $\begin{array}{l}\text { Educação } \\
\text { Ambiental } \\
\text { (contratos) }\end{array}$ & 60000 & PDC01 & 12 & $\begin{array}{l}\text { EDUC. AMBIENTAL-ALTOS DO } \\
\text { PARANAPIACABA }\end{array}$ \\
\hline $\begin{array}{l}\text { PREFEITURA } \\
\text { MUNICIPAL DE } \\
\text { SALTO }\end{array}$ & $\begin{array}{l}\text { PREFEITURA } \\
\text { MUNICIPAL }\end{array}$ & Cancelado & $16 / 01 / 2004$ & $32.845,84$ & $8.211,46$ & $41.057,30$ & Município & Não reemb. & $\begin{array}{c}\text { Coleta e } \\
\text { Tratamento de } \\
\text { Esgotos } \\
\text { (habitantes) }\end{array}$ & 20000 & $\mathrm{PDCO}_{3}$ & 12 & IMPLANTAÇÃO DE REDE DE ESGOTO \\
\hline $\begin{array}{l}\text { FUNDAÇ̃̃O SOS } \\
\text { MATA ATLANTICA }\end{array}$ & $\begin{array}{l}\text { DEFESA DO MEIO } \\
\text { AMBIENTEE } \\
\text { RECURSOS } \\
\text { HÍDRICOS }\end{array}$ & Conclú́do & 07/07/2009 & $104.500,00$ & $26.125,00$ & $130.625,00$ & Sociedade Civil & Não reemb. & $\begin{array}{l}\text { Educação } \\
\text { Ambiental } \\
\text { (contratos) }\end{array}$ & 200000 & PDC01 & 12 & REDE DE INFORMAÇÕES II \\
\hline $\begin{array}{l}\text { PREFEITURA } \\
\text { MUNICIPAL DE } \\
\text { PIEDADE }\end{array}$ & $\begin{array}{l}\text { PREFEITURA } \\
\text { MUNICIPAL }\end{array}$ & Concluído & 22/08/2007 & $119.992,47$ & $347.238,72$ & $467.231,19$ & Munićpio & Não reemb. & $\begin{array}{l}\text { Trat.e Disposição } \\
\text { de Lixo - Obras } \\
\text { (habitantes) }\end{array}$ & 35000 & $\mathrm{PDC} 03$ & 12 & DESTINAÇÃO DELIXO \\
\hline $\begin{array}{l}\text { PREFEITURA } \\
\text { MUNICIPAL DE } \\
\text { BOITUVA }\end{array}$ & $\begin{array}{l}\text { PREFEITURA } \\
\text { MUNICIPAL }\end{array}$ & Conclú́do & $10 / 12 / 2009$ & $126.296,49$ & $35.999,54$ & $162.296,03$ & Munićpio & Não reemb. & $\begin{array}{l}\text { Abastecimento de } \\
\text { Água (habitantes) }\end{array}$ & 20000 & PDC09 & 12 & $\begin{array}{l}\text { PRESERVAÇÃO DA NASCENTEE } \\
\text { PARTE DO RIBEIRÃ O PAU D' ÁLHO }\end{array}$ \\
\hline $\begin{array}{c}\text { SERVICCO } \\
\text { AUTÔNOMO DE } \\
\text { ÁGUA EESGOTO DE } \\
\text { PORTO FELIZ (SAAE) }\end{array}$ & $\begin{array}{l}\text { PREFEITURA } \\
\text { MUNICIPAL }\end{array}$ & Conclú́do & $16 / 10 / 2007$ & $100.000,00$ & $29.957,55$ & $129.957,55$ & Município & Não reemb. & $\begin{array}{l}\text { Abastecimento de } \\
\text { Água (habitantes) }\end{array}$ & 42000 & PDC01 & 12 & $\begin{array}{c}\text { PLANO DIRETOR DE ÁGUA, RESÍDUOS } \\
\text { E REF. TOPOGRÁFICAS }\end{array}$ \\
\hline $\begin{array}{l}\text { FUNDIBIOS - } \\
\text { FUND.APOIO INST. } \\
\text { DES. CIENT. E } \\
\text { TECNOLÓGICO } \\
\text { PREFEITURA }\end{array}$ & & Cancelado & $24 / 11 / 2003$ & 0 & 0 & 0 & & Não reemb. & Outros (contratos) & 1500000 & PDC01 & 0 & $\begin{array}{l}\text { ELABORAÇÃO DE UM BANCO DE } \\
\text { DADOS AMBIENTAIS }\end{array}$ \\
\hline $\begin{array}{c}\text { MUNICIPAL DE } \\
\text { ARAÇOIABA DA } \\
\text { SERRA }\end{array}$ & $\begin{array}{l}\text { PREFEITURA } \\
\text { MUNICIPAL }\end{array}$ & Cancelado & 01/08/2003 & 0 & 0 & 0 & Município & Não reemb. & Outros (contratos) & 10000 & PDC09 & 0 & $\begin{array}{l}\text { OBRAS DO SISTEMA DE CAPTAÇÃO } \\
\text { DE AGUAS PLUVIAIS }\end{array}$ \\
\hline
\end{tabular}




\begin{tabular}{|c|c|c|c|c|c|c|c|c|c|c|c|c|c|}
\hline Nome do interessado & $\begin{array}{l}\text { Atividade principal do } \\
\text { interessado }\end{array}$ & $\begin{array}{c}\text { Situacão do } \\
\text { empreendimento }\end{array}$ & $\begin{array}{l}\text { Data de } \\
\text { conclusão }\end{array}$ & Valor aprovado & $\begin{array}{c}\text { Valor de } \\
\text { contrapartida }\end{array}$ & Valor total & $\begin{array}{l}\text { Segmento do } \\
\text { interessado }\end{array}$ & Modalidade & $\begin{array}{l}\text { Benefício: } \\
\text { indicador }\end{array}$ & $\begin{array}{l}\text { Populacã̃o } \\
\text { beneficiada }\end{array}$ & PDC: sigla & $\begin{array}{l}\text { Tempo de } \\
\text { execução } \\
\text { (meses) }\end{array}$ & Descrição \\
\hline $\begin{array}{l}\text { PREFEITURA } \\
\text { MUNICIPALDDE } \\
\text { PIEDADE } \\
\text { SERVIÇO }\end{array}$ & $\begin{array}{l}\text { PREFEITURA } \\
\text { MUNICIPAL }\end{array}$ & Concluído & $18 / 05 / 2006$ & $36.786,31$ & $15.723,05$ & $52.509,36$ & Município & Não reemb. & $\begin{array}{l}\text { Recomposição de } \\
\text { Mata Ciliar } \\
\text { (hectares) }\end{array}$ & 30000 & PDC05 & 12 & $\begin{array}{l}\text { PROGRAMA DE FOMENTO P/ } \\
\text { RECOMPOSIÇÃAO DE MATA CILIAR }\end{array}$ \\
\hline $\begin{array}{l}\text { AUTÔNOMO } \\
\text { MUNIIIPLLDE } \\
\text { ÁGUA EESGOTO DE } \\
\text { TIETÊ-SAMAE }\end{array}$ & $\begin{array}{l}\text { SANEAMENTO } \\
\text { PÚBLICO }\end{array}$ & Concluído & $01 / 07 / 2009$ & $119.817,60$ & $29.500,00$ & $149.317,60$ & Município & Não reemb. & $\begin{array}{l}\text { Abastecimento de } \\
\text { Água (habitantes) }\end{array}$ & 100000 & PDC05 & 48 & $\begin{array}{l}\text { ESTUDOS E PROJETOS PARA } \\
\text { DIMENSIONAMENTO DE SISTEMA } \\
\text { PRODUTOR DE ÁGUA }\end{array}$ \\
\hline $\begin{array}{l}\text { DEPARTAMENTO DE } \\
\text { AGUAS E ENERGIA } \\
\text { ELETRICA - DAEE } \\
\text { (SÃO PAULO) }\end{array}$ & $\begin{array}{l}\text { AUTARQUIA } \\
\text { PÚBLICA } \\
\text { ESTADUALL }\end{array}$ & Concluído & 20/07/2000 & $514.506,32$ & $131.100,00$ & $645.606,32$ & Estado & Não reemb. & $\begin{array}{l}\text { Galerias de Águas } \\
\text { Pluviais (metros } \\
\text { lineares) }\end{array}$ & 5000 & PDC08 & 12 & $\begin{array}{c}\text { OBRAS DE DRENAGEM DE ÁGUAS } \\
\text { PLUVIAIS PARA COMBATEE } \\
\text { PREVENÇÃO Ȧ EROSÃO NOS CJ. HAB. } \\
\text { CDHU1 ECDHU2 }\end{array}$ \\
\hline $\begin{array}{l}\text { SERVIÇO } \\
\text { AUTÔNOMO DE } \\
\text { ÁGUA EESGOTO DE } \\
\text { VOTORANTIM - } \\
\text { SAAE - } \\
\text { UNESP - }\end{array}$ & $\begin{array}{l}\text { PREFEITURA } \\
\text { MUNICIPAL }\end{array}$ & Concluído & $04 / 12 / 2000$ & $13.600,00$ & $4.000,00$ & $17.600,00$ & Município & Não reemb. & $\begin{array}{l}\text { Coleta e } \\
\text { Tratamento de } \\
\text { Esgotos } \\
\text { (habitantes) }\end{array}$ & 20000 & $\mathrm{PDC} 03$ & 12 & $\begin{array}{c}\text { - LOCAL: TRECHO COMPREENDIDO } \\
\text { ENTRE OS TRECHOS DA ETE JD.NOVO } \\
\text { MUNDO ATÉ A JUSANTE DEA } \\
\text { CAPTAÇÃO IPANEM }\end{array}$ \\
\hline $\begin{array}{l}\text { UNIVERSIDADE } \\
\text { ESTADUAL } \\
\text { PAULISTA JÚLIO DE } \\
\text { MESQUITA FILHO } \\
\text { SERVICO }\end{array}$ & $\begin{array}{l}\text { INSTITUIÇÃO DE } \\
\text { ENSINO SUPERIOR }\end{array}$ & Concluído & 19/09/2002 & $105.000,00$ & $16.000,00$ & $121.000,00$ & Estado & Não reemb. & $\begin{array}{l}\text { Planej. e Gerenc. } \\
\text { dos Recs. Hídricos } \\
\text { (contratos) }\end{array}$ & 50000 & PDC01 & 12 & $\begin{array}{l}\text { CARACTERIZAÇ̃̃O GEO-AMBIENTAL } \\
\text { DA REPRESA DE ITUPARARANGA }\end{array}$ \\
\hline $\begin{array}{l}\text { AUTÔNOMO DE } \\
\text { ÁGUA EESGOTO DE } \\
\text { VOTORANTIM - } \\
\text { SAAE }\end{array}$ & $\begin{array}{l}\text { PREFEITURA } \\
\text { MUNICIPAL }\end{array}$ & Concluído & 19/06/2002 & $60.000,00$ & $15.000,00$ & $75.000,00$ & Município & Não reemb. & $\begin{array}{l}\text { Trat. e Disposicião } \\
\text { de Lixo - Obras } \\
\text { (habitantes) }\end{array}$ & 100000 & $\mathrm{PDCO}_{3}$ & 12 & $\begin{array}{l}\text { ELABORAČ̃̃O DE PLANO DIRETOR DE } \\
\text { RESÍDUOS SÓLIDOS PARA O } \\
\text { MUNIĆIPIO DE VOTORANTIM }\end{array}$ \\
\hline $\begin{array}{l}\text { FUNDAÇÃO SOS } \\
\text { MATA ATLANTICA }\end{array}$ & $\begin{array}{l}\text { DEFESA DO MEIO } \\
\text { AMBIENTE E } \\
\text { RECURSOS } \\
\text { HIDRICOS }\end{array}$ & Concluído & $04 / 08 / 2000$ & $63.783,00$ & $15.946,00$ & $79.729,00$ & Sociedade Civil & Não reemb. & $\begin{array}{l}\text { Educação } \\
\text { Ambiental } \\
\text { (contratos) }\end{array}$ & 10000 & PDC01 & 12 & $\begin{array}{l}\text { EDUCAÇÃO AMBIENTAL- } \\
\text { OBSERVANDO A BACAA DO } \\
\text { SOROCABA E MEDIO TIETÊ }\end{array}$ \\
\hline $\begin{array}{l}\text { SERVIÇO } \\
\text { AUTOONOMO DE } \\
\text { ÁGUA E ESGOTO DE } \\
\text { SOROCABA -SAAE- }\end{array}$ & $\begin{array}{l}\text { PREFEITURA } \\
\text { MUNICIPAL }\end{array}$ & Concluído & $24 / 08 / 2006$ & $170.000,00$ & $50.000,00$ & $220.000,00$ & Município & Não reemb. & $\begin{array}{l}\text { Coleta e } \\
\text { Tratamento de } \\
\text { Esgotos } \\
\text { (habitantes) }\end{array}$ & 80000 & $\mathrm{PDC0} 3$ & 12 & $\begin{array}{c}\text { ELABORAÇÃO DO PROJETO } \\
\text { EXECUTIVO DA EST. TRAT. ESGOTOS } \\
\text { DE ITANGUÁ }\end{array}$ \\
\hline $\begin{array}{l}\text { SERVIÇO } \\
\text { AUTÔNOMO DE } \\
\text { ÁGUA EESGOTO DE } \\
\text { SOROCABA-SAAE- }\end{array}$ & $\begin{array}{l}\text { PREFEITURA } \\
\text { MUNICIPAL }\end{array}$ & Concluído & 13/09/2000 & $77.606,20$ & $50.297,00$ & $127.903,20$ & Município & Não reemb. & $\begin{array}{l}\text { Estudos/Projetos } \\
\text { (contratos) }\end{array}$ & 10000 & PDC01 & 1 & $\begin{array}{l}\text { PROJETO DE ESTUDO DE } \\
\text { PRESERVACCÃ̃, CONSERVACCÃO E } \\
\text { RECUPERAÇÃO DO MANANCIAL } \\
\text { IPANEMINHA }\end{array}$ \\
\hline $\begin{array}{l}\text { PREFEITURA } \\
\text { MUNICIPALDE } \\
\text { CERQULHO }\end{array}$ & $\begin{array}{l}\text { PREFEITURA } \\
\text { MUNICIPAL }\end{array}$ & Concluído & $24 / 10 / 2001$ & $23.291,84$ & $5.822,96$ & $29.114,80$ & Município & Não reemb. & $\begin{array}{l}\text { Trat. e Disposição } \\
\text { de Lixo - Obras } \\
\text { (habitantes) }\end{array}$ & 30000 & $\mathrm{PDCO}_{3}$ & 12 & $\begin{array}{l}\text { ELABORAÇÃO DE PROJETO DE } \\
\text { ATERRO SANITÁRIO EM VALAS }\end{array}$ \\
\hline $\begin{array}{l}\text { PREFEITURA } \\
\text { MUNICIPALDE } \\
\text { PORANGABA }\end{array}$ & $\begin{array}{l}\text { PREFEITURA } \\
\text { MUNICIPAL }\end{array}$ & Concluído & 10/07/2002 & $73.653,60$ & $23.000,00$ & $96.653,60$ & Município & Não reemb. & $\begin{array}{l}\text { Trat. e Disp. de } \\
\text { Lixo - } \\
\text { Véculos /Equips. } \\
\text { (contratos) }\end{array}$ & 6500 & $\mathrm{PDCO} 3$ & 6 & $\begin{array}{l}\text { AQUISIČ̃̃O DE CAMINHÃO COM } \\
\text { COLETOR COMPACTADOR DE LIXO } \\
\text { PARA O MUNIĆ́PIO DE PORANGABA }\end{array}$ \\
\hline $\begin{array}{l}\text { COMANDO DE } \\
\text { POLICIAMENTO } \\
\text { AMBIENTAL- }{ }^{\circ} \\
\text { BATALHÃO } 3^{\mathrm{a}} \text { CIA - } \\
\text { SOROCABA }\end{array}$ & $\begin{array}{l}\text { POLICIAMENTOE E } \\
\text { FISCALIZAÇÃO } \\
\text { AMBIENTAL }\end{array}$ & Concluído & 19/01/2001 & $99.524,00$ & $32.200,00$ & $131.724,00$ & Estado & Não reemb. & $\begin{array}{l}\text { Educação } \\
\text { Ambiental } \\
\text { (contratos) }\end{array}$ & 5000 & PDC01 & 12 & $\begin{array}{l}\text { PROJETO DE ATIVIDADE DA } \\
\text { EDUCAÇÃO AMBIENTAL }\end{array}$ \\
\hline $\begin{array}{l}\text { COMPANHIA DE } \\
\text { SANEAMENTO } \\
\text { BÁSICO DO ESTADO } \\
\text { DE SÃO PAULO - } \\
\text { SABESP }\end{array}$ & $\begin{array}{c}\text { SANEAMENTO } \\
\text { BÁSICO }\end{array}$ & Cancelado & 09/06/2005 & $76.621,51$ & $19.155,38$ & $95.776,89$ & Estado & Não reemb. & $\begin{array}{l}\text { Estudos/Projetos } \\
\text { (contratos) }\end{array}$ & 8893 & $\mathrm{PDC} 03$ & 6 & $\begin{array}{c}\text { PROJETO EXECUTIVO PARA } \\
\text { AFASTAMENTO E TRATAMENTO DE } \\
\text { ESGOTOS NO MUNICÍPIO DE CESÁRIO } \\
\text { LANGE }\end{array}$ \\
\hline
\end{tabular}




\begin{tabular}{|c|c|c|c|c|c|c|c|c|c|c|c|c|c|}
\hline Nome do interessado & $\begin{array}{l}\text { Atividade principal do } \\
\text { interessado }\end{array}$ & $\begin{array}{l}\text { Situação do } \\
\text { empreendimento }\end{array}$ & $\begin{array}{l}\text { Data de } \\
\text { conclusão }\end{array}$ & Valor aprovado & $\begin{array}{c}\text { Valor de } \\
\text { contrapartida }\end{array}$ & Valor total & $\begin{array}{l}\text { Segmento do } \\
\text { interessado }\end{array}$ & Modalidade & $\begin{array}{l}\text { Benefício: } \\
\text { indicador }\end{array}$ & $\begin{array}{c}\text { Populacacão } \\
\text { beneficiada }\end{array}$ & PDC: sigla & $\begin{array}{l}\text { Tempo de } \\
\text { execução } \\
\text { (meses) }\end{array}$ & Descrição \\
\hline $\begin{array}{c}\text { CONSÓRCIO DE } \\
\text { ESTUDOS, } \\
\text { RECUPERAÇÃOE } \\
\text { DESENVOLVIMENTO } \\
\text { DA BACIA DOS RIOS } \\
\text { SOROCABA E MÉDIO } \\
\text { TIETÊ - CERISO }\end{array}$ & $\begin{array}{l}\text { CONSÓRCIO } \\
\text { INTERMUNICIPAL }\end{array}$ & Concluído & 05/06/2009 & $144.000,00$ & 0 & $178.750,11$ & Sociedade Civil & Não reemb. & $\begin{array}{l}\text { Estudos/Projetos } \\
\quad \text { (contratos) }\end{array}$ & 500000 & PDC01 & 12 & \\
\hline $\begin{array}{l}\text { PREFEITURA } \\
\text { MUNICIPAL DE } \\
\text { JUMIRIM }\end{array}$ & $\begin{array}{l}\text { PREFEITURA } \\
\text { MUNICIPAL }\end{array}$ & Concluído & 02/01/2002 & $24.000,00$ & $6.000,00$ & $30.000,00$ & Município & Não reemb. & $\begin{array}{l}\text { Coleta e } \\
\text { Tratamento de } \\
\text { Esgotos } \\
\text { (habitantes) }\end{array}$ & 2000 & $\mathrm{PDC} 03$ & 12 & $\begin{array}{c}\text { PROJETO REDE COLETORA, EMISSÁRIO } \\
\text { E SISTEMA DE TRATAMENTO DE } \\
\text { ESGOTOS }\end{array}$ \\
\hline $\begin{array}{c}\text { SERVIÇO } \\
\text { AUTONNOMO DE } \\
\text { ÁGUA EESGOTO DE } \\
\text { VOTORANTIM - } \\
\text { SAAE }\end{array}$ & $\begin{array}{l}\text { PREFEITURA } \\
\text { MUNICIPAL }\end{array}$ & Concluído & 04/07/2003 & $95.600,00$ & $24.000,00$ & $119.600,00$ & Município & Não reemb. & $\begin{array}{l}\text { Estudos/Projetos } \\
\quad \text { (contratos) }\end{array}$ & 56537 & $\mathrm{PDC} 03$ & 3 & $\begin{array}{l}\text { ELABORAÇÃO DO PROJETO BÁSICO } \\
\text { DAS OBRAS LINEARES E DA E.T.E. DE } \\
\text { VOTORARANTIM. }\end{array}$ \\
\hline $\begin{array}{l}\text { SERVIÇO } \\
\text { AUTOONOMO DE } \\
\text { ÁGUA EEGOTO DE } \\
\text { ITU }\end{array}$ & $\begin{array}{l}\text { PREFEITURA } \\
\text { MUNICIPAL }\end{array}$ & Cancelado & $11 / 09 / 2003$ & $87.280,00$ & $28.800,00$ & $116.080,00$ & Município & Não reemb. & Outros (contratos) & 0 & PDC01 & 0 & $\begin{array}{l}\text { DIAGN.DOS CONFLITOS ATUAIS E } \\
\text { POTENCIAIS DECRRENTES DA } \\
\text { RELAÇÃO:REC.HÍDRICOS X USO E } \\
\text { OCUPAÇÃO DO SOLO }\end{array}$ \\
\hline $\begin{array}{l}\text { FUNDACC̃̃O SOS } \\
\text { MATA ATLANTICA }\end{array}$ & $\begin{array}{l}\text { DEFESA DO MEIO } \\
\text { AMBIENTEE } \\
\text { RECURSOS } \\
\text { HIIDRICOS }\end{array}$ & Concluído & 10/09/2001 & $50.000,00$ & $12.500,00$ & $62.500,00$ & Sociedade Civil & Não reemb. & $\begin{array}{l}\text { Educação } \\
\text { Ambiental } \\
\text { (contratos) }\end{array}$ & 10000 & PDC01 & 12 & $\begin{array}{c}\text { - DISPONIBILIZAÇ̃̃OO DE } \\
\text { INFORMAÇÕES DA REGIIAOO DA BACIA } \\
\text { DO COMTEE DO SOROCABA E MÉDIO } \\
\text { TIETÊ VIA INTERNE }\end{array}$ \\
\hline $\begin{array}{l}\text { COMPANHIA DE } \\
\text { SANEAMENTO } \\
\text { BÁSICO DO ESTADO } \\
\text { DE SÃO PAULO - } \\
\text { SABESP }\end{array}$ & $\begin{array}{l}\text { SANEAMENTO } \\
\text { BÁSICO }\end{array}$ & Concluído & 19/10/2001 & $93.504,81$ & $62.336,54$ & $155.841,35$ & Estado & Não reemb. & $\begin{array}{l}\text { Coleta e } \\
\text { Tratamento de } \\
\text { Esgotos } \\
\text { (habitantes) }\end{array}$ & 15000 & $\mathrm{PDC} 03$ & 12 & $\begin{array}{l}\text { ELABORAÇÃO DO PROJETO DO } \\
\text { SISTEMA DE ESGOTOS SANTÍ́RIIOS } \\
\text { DA CIDADE DE ALUMIINIO }\end{array}$ \\
\hline $\begin{array}{l}\text { PREFEITURA } \\
\text { MUNICIPAL DE } \\
\text { ALUMÍNIO }\end{array}$ & $\begin{array}{l}\text { PREFEITURA } \\
\text { MUNICIPAL }\end{array}$ & Concluído & $13 / 12 / 2000$ & $105.969,40$ & $26.492,36$ & $132.461,76$ & Município & Não reemb. & $\begin{array}{l}\text { Galerias de Águas } \\
\text { Pluviais (metros } \\
\text { lineares) }\end{array}$ & 1300 & PDC09 & 12 & $\begin{array}{l}\text { - BENEFí́CIOS: CONTER ENCOSTAS, } \\
\text { PREVININDO CONTRA EROSÕES NA } \\
\text { VILA RÉ; - LOCAL: VILA RÉ. }\end{array}$ \\
\hline $\begin{array}{l}\text { PREFEITURA } \\
\text { MUNICIPAL DE } \\
\text { ALUMÍNIO }\end{array}$ & $\begin{array}{l}\text { PREFEITURA } \\
\text { MUNICIPAL }\end{array}$ & Concluído & 09/08/2000 & $8.000,00$ & $6.000,00$ & $14.000,00$ & Município & Não reemb. & $\begin{array}{l}\text { Trat. e Disposição } \\
\text { de Lixo - Obras } \\
\text { (habitantes) }\end{array}$ & 15000 & $\mathrm{PDC} 03$ & 12 & $\begin{array}{c}\text { - O PROJETO PROCURA ATENDERÉ É } \\
\text { SOLUÇÃO MAIS INDICADA PARA A } \\
\text { DESTINAÇÃO FINAL DOS REŚÍDUOS } \\
\text { SÓLDDOS D }\end{array}$ \\
\hline $\begin{array}{l}\text { SERVIÇO } \\
\text { AUTOONOMO DE } \\
\text { ÁGUA EESGOTO DE } \\
\text { CERQUILHO }\end{array}$ & $\begin{array}{l}\text { SERVIÇO DE } \\
\text { SANEAMENTO } \\
\text { BÁSICO }\end{array}$ & Concluído & $02 / 10 / 2000$ & $118.480,00$ & $29.620,00$ & $148.100,00$ & Município & Não reemb. & $\begin{array}{c}\text { Coleta e } \\
\text { Tratamento de } \\
\text { Esgotos } \\
\text { (habitantes) }\end{array}$ & 30000 & $\mathrm{PDCO}_{3}$ & 12 & $\begin{array}{l}\text { PROJETO DE ENGENHARIA DO } \\
\text { SISTEMA DE ESGOTOS SANITÁRIOS }\end{array}$ \\
\hline $\begin{array}{l}\text { COMPANHIA DE } \\
\text { SANEAMENTO } \\
\text { BÁSICO DO ESTADO } \\
\text { DE SÃO PAULO - } \\
\text { SABESP }\end{array}$ & $\begin{array}{l}\text { SANEAMENTO } \\
\text { BÁSICO }\end{array}$ & Concluído & $25 / 11 / 2004$ & $66.510,35$ & $16.627,59$ & $83.137,94$ & Estado & Não reemb. & $\begin{array}{l}\text { Coleta e } \\
\text { Tratamento de } \\
\text { Esgotos } \\
\text { (habitantes) }\end{array}$ & 17841 & $\mathrm{PDC} 03$ & 4 & $\begin{array}{l}\text { CONCLUSÃO DO PROJETO EXECUTIVO } \\
\text { DO SISTEMA DE ESGOTOS } \\
\text { SANITÁRIOS DE LARANJAL PAULISTA }\end{array}$ \\
\hline $\begin{array}{l}\text { CONSÓRCIO DE } \\
\text { ESTUDOS, } \\
\text { RECUPERAÇÃ̃OE } \\
\text { DESENVOLVIMENTO } \\
\text { DA BACIA DOS RIOS }\end{array}$ & $\begin{array}{l}\text { CONSÓRCIO } \\
\text { INTERMUNICIPAL }\end{array}$ & Concluído & 13/02/2006 & $117.100,00$ & $37.105,00$ & $154.205,00$ & Sociedade Civil & Não reemb. & $\begin{array}{l}\text { Abastecimento de } \\
\text { Água (habitantes) }\end{array}$ & 612190 & PDC05 & 6 & $\begin{array}{l}\text { PLANO DIRETOR DE COMBATE ̀̀S } \\
\text { PERDAS TOTAIS DE ÁGUA - } \\
\text { ELABORAÇÃO DE PROJETOS PARA } \\
\text { COMBATE ÀS PERDAS TO }\end{array}$ \\
\hline $\begin{array}{l}\text { PREFEITURA } \\
\text { MUNICIPAL DE } \\
\text { CESÁRIO LANGE }\end{array}$ & $\begin{array}{l}\text { PÚBLICA/EXECUTIV } \\
\text { A }\end{array}$ & Concluído & 19/12/2005 & $46.660,24$ & $11.665,06$ & $58.325,30$ & Município & Não reemb. & $\begin{array}{l}\text { Estudos/Projetos } \\
\text { (contratos) }\end{array}$ & 13000 & PDC09 & 12 & $\begin{array}{l}\text { RECUPERACCÃO E CONSERVAÇÃO DE } \\
\text { MATA CILIAR }\end{array}$ \\
\hline $\begin{array}{l}\text { SERVIÇO } \\
\text { AUTÔNOMO DE } \\
\text { ÁGGA EESGOTO DE } \\
\text { SOROCABA-SAAE- }\end{array}$ & $\begin{array}{l}\text { PREFEITURA } \\
\text { MUNICIPAL }\end{array}$ & Concluído & $25 / 11 / 2004$ & $127.160,00$ & $313.662,00$ & $440.822,00$ & Município & Não reemb. & $\begin{array}{l}\text { Coleta e } \\
\text { Tratamento de } \\
\text { Esgotos } \\
\text { (habitantes) }\end{array}$ & 80000 & $\mathrm{PDC} 03$ & 12 & \\
\hline $\begin{array}{l}\text { SECRETARIA DE } \\
\text { ESTADO DO MEIO } \\
\text { AMBIENTE - SMA }\end{array}$ & $\begin{array}{l}\text { LICENCIAMENTOE } \\
\text { FISCALIZAÇÃO } \\
\text { AMBIENTAL }\end{array}$ & Concluído & 08/10/2004 & $40.000,00$ & $9.650,00$ & $49.650,00$ & Estado & Não reemb. & $\begin{array}{l}\text { Educação } \\
\text { Ambiental } \\
\text { (contratos) }\end{array}$ & 100000 & PDC01 & 12 & $\begin{array}{l}\text { PROJETO DE EDUCAÇ̃̃O AMBIENTAL } \\
\text { RODA D'ÁGUA }\end{array}$ \\
\hline
\end{tabular}




\begin{tabular}{|c|c|c|c|c|c|c|c|c|c|c|c|c|c|}
\hline Nome do interessado & $\begin{array}{l}\text { Atividade principal do } \\
\text { interessado }\end{array}$ & $\begin{array}{c}\text { Situação do } \\
\text { empreendimento }\end{array}$ & $\begin{array}{l}\text { Data de } \\
\text { conclusão }\end{array}$ & Valor aprovado & $\begin{array}{c}\text { Valor de } \\
\text { contrapartida }\end{array}$ & Valor total & $\begin{array}{l}\text { Segmento do } \\
\text { interessado }\end{array}$ & Modalidade & $\begin{array}{l}\text { Benefício: } \\
\text { indicador }\end{array}$ & $\begin{array}{l}\text { População } \\
\text { beneficiada }\end{array}$ & PDC: sigla & $\begin{array}{l}\text { Tempo de } \\
\text { execução } \\
\text { (meses) }\end{array}$ & Descrição \\
\hline $\begin{array}{l}\text { PREFEITURA } \\
\text { MUNICIPALDE } \\
\text { JUMIRIM }\end{array}$ & $\begin{array}{l}\text { PREFEITURA } \\
\text { MUNICIPAL }\end{array}$ & Concluído & $05 / 02 / 2004$ & $139.107,73$ & $14.779,99$ & $153.887,72$ & Município & Não reemb. & $\begin{array}{l}\text { Coleta e } \\
\text { Tratamento de } \\
\text { Esgotos } \\
\text { (habitantes) }\end{array}$ & 2000 & $\mathrm{PDC} 03$ & 12 & $\begin{array}{l}\text { OBRAS DA ESTAČ̃̃O DE } \\
\text { TRATAMENTO DEESGOTO }\end{array}$ \\
\hline $\begin{array}{c}\text { PREFEITURA } \\
\text { MUNICIPALDE } \\
\text { ARAÇOIABA DA } \\
\text { SERRA }\end{array}$ & $\begin{array}{l}\text { PREFEITURA } \\
\text { MUNICIPAL }\end{array}$ & Concluído & $28 / 08 / 2002$ & $47.960,00$ & $11.990,00$ & $59.950,00$ & Município & Não reemb. & $\begin{array}{l}\text { Galerias de Águas } \\
\text { Pluviais (metros } \\
\quad \text { lineares) }\end{array}$ & 1000 & PDC09 & 12 & $\begin{array}{l}\text { SISTEMA DE CAPTAĈ̃̃ DEÉGGUAS } \\
\text { PLUVIAIS DA ZONA URBANA }\end{array}$ \\
\hline $\begin{array}{c}\text { SERVIÇO } \\
\text { AUTÔNOMO DE } \\
\text { ÁGUA EESGOTO DE } \\
\text { ITU }\end{array}$ & $\begin{array}{l}\text { PREFEITURA } \\
\text { MUNICIPAL }\end{array}$ & Concluído & $17 / 05 / 2005$ & $49.700,00$ & $21.300,00$ & $71.000,00$ & Município & Não reemb. & $\begin{array}{l}\text { Estudos/Projetos } \\
\quad \text { (contratos) }\end{array}$ & 25000 & PDC05 & 12 & $\begin{array}{l}\text { ESTUDOS DE RECUPERAČ̃̃O DO } \\
\text { RESERVATÓRIO ITAIM NO MUNICÍPIO } \\
\text { DEITU }\end{array}$ \\
\hline $\begin{array}{l}\text { PREFEITURA } \\
\text { MUNIIIALDE } \\
\text { LARANJAL } \\
\text { PAULISTA }\end{array}$ & $\begin{array}{l}\text { PREFEITURA } \\
\text { MUNICIPAL }\end{array}$ & Concluído & $28 / 02 / 2002$ & $23.917,50$ & $18.076,00$ & $41.993,50$ & Município & Não reemb. & $\begin{array}{l}\text { Estudos/Projetos } \\
\quad \text { (contratos) }\end{array}$ & 20000 & PDC01 & 12 & $\begin{array}{l}\text { LEVANTAMENTO DOS IMPACTOS NOS } \\
\text { RECURSOS HÍDRICOS ECARTA } \\
\text { GEOTÉCNICA - DIRETRIZES P/ } \\
\text { PLANEJAMENTO URB. }\end{array}$ \\
\hline $\begin{array}{l}\text { PREFEITURA } \\
\text { MUNICIPALDE } \\
\text { BOFETE }\end{array}$ & $\begin{array}{l}\text { PREFEITURA } \\
\text { MUNICIPAL }\end{array}$ & Concluído & 20/11/2003 & $150.000,00$ & $146.474,20$ & $296.474,20$ & Município & Não reemb. & $\begin{array}{l}\text { Galerias de Águas } \\
\text { Pluviais (metros } \\
\text { lineares) }\end{array}$ & 3500 & PDC09 & 12 & $\begin{array}{l}\text { GALERIAS DE ÁGUAS PLUVIAIS - } \\
\text { DIVERSAS RUAS DO MUNICÍPIO }\end{array}$ \\
\hline $\begin{array}{l}\text { PREFEITURA } \\
\text { MUNICIPAL DE } \\
\text { ARAÇOIABA DA } \\
\text { SERRA }\end{array}$ & $\begin{array}{l}\text { PREFEITURA } \\
\text { MUNICIPAL }\end{array}$ & Concluído & 12/02/2004 & $57.600,00$ & $14.504,29$ & $72.104,29$ & Município & Não reemb. & $\begin{array}{l}\text { Educação } \\
\text { Ambiental } \\
\text { (contratos) }\end{array}$ & 10000 & $\mathrm{PDC} 03$ & 12 & $\begin{array}{l}\text { EDUCAÇÃO AMBIENTAL - COLETA } \\
\text { SELETIVA DE LIXO }\end{array}$ \\
\hline $\begin{array}{l}\text { PREFEITURA } \\
\text { MUNICIPALDE } \\
\text { ARAÇOIABA DA } \\
\text { SERRA }\end{array}$ & $\begin{array}{l}\text { PREFEITURA } \\
\text { MUNICIPAL }\end{array}$ & Cancelado & $11 / 02 / 2004$ & $7.600,00$ & $1.900,00$ & $9.500,00$ & Município & Não reemb. & $\begin{array}{l}\text { Estudos/Projetos } \\
\text { (contratos) }\end{array}$ & 15000 & PDC09 & 6 & $\begin{array}{l}\text { PROJETO TÉCNICO DE RECUPERAÇ̃̃O } \\
\text { DE MANANCIAL DA BAHIA DO } \\
\text { CÓRREGO LAGEADO }\end{array}$ \\
\hline $\begin{array}{l}\text { PREFEITURA } \\
\text { MUNICIPALDE } \\
\text { CONCHAS }\end{array}$ & $\begin{array}{l}\text { PREFEITURA } \\
\text { MUNICIPAL }\end{array}$ & Concluído & 18/07/2011 & $146.865,76$ & $49.545,21$ & $196.410,97$ & Município & Não reemb. & $\begin{array}{l}\text { Trat. e Disp. de } \\
\text { Lixo - } \\
\text { Veículos/Equips. } \\
\text { (contratos) }\end{array}$ & 15000 & PDC05 & 12 & $\begin{array}{l}\text { PROGRAMA DE GERENCIAMENTO } \\
\text { INTEGRADO PARTICIPATIVO DOS } \\
\text { RESÍDUOS SÓLIDOS GERADOS NO } \\
\text { MUNICÍPIO DE CONCH }\end{array}$ \\
\hline $\begin{array}{l}\text { PREFEITURA } \\
\text { MUNICIPALDE } \\
\text { ARAÇOIABA DA } \\
\text { SERRA }\end{array}$ & $\begin{array}{l}\text { PREFEITURA } \\
\text { MUNICIPAL }\end{array}$ & Concluído & $11 / 07 / 2005$ & $51.600,00$ & $12.900,00$ & $64.500,00$ & Município & Não reemb. & $\begin{array}{l}\text { Estudos/Projetos } \\
\quad \text { (contratos) }\end{array}$ & 4000 & PDC09 & 12 & $\begin{array}{l}\text { PROJETO TÉCNICO DE CONTENČ̃̃o } \\
\text { DOS PROCESSOS EROSIVOS DO BAIRRO } \\
\text { SÃO ROQUE }\end{array}$ \\
\hline $\begin{array}{c}\text { SERVICCO } \\
\text { AUTÔNOMO DE } \\
\text { ÁGUA EESGOTO DE } \\
\text { PORTO FELLZ (SAAE) }\end{array}$ & $\begin{array}{l}\text { PREFEITURA } \\
\text { MUNICIPAL }\end{array}$ & Concluído & 26/11/2004 & $117.595,00$ & $92.405,00$ & $210.000,00$ & Município & Não reemb. & $\begin{array}{l}\text { Estudos/Projetos } \\
\text { (contratos) }\end{array}$ & 42000 & $\mathrm{PDC} 03$ & 12 & $\begin{array}{c}\text { TERMO REFERENCIA PARA } \\
\text { ELABORAÇÃO PROEETO BÁSICO DA } \\
\text { ETEEELEVATÓRIAS }\end{array}$ \\
\hline $\begin{array}{l}\text { PREFEITURA } \\
\text { MUNICIPAL DE } \\
\text { PEREIRAS }\end{array}$ & $\begin{array}{l}\text { PREFEITURA } \\
\text { MUNICIPAL }\end{array}$ & Concluído & $30 / 12 / 2004$ & $70.623,20$ & $23.000,00$ & $93.623,20$ & Município & Não reemb. & $\begin{array}{l}\text { Trat. e Disposiç̃̃o } \\
\text { de Lixo - Obras } \\
\text { (habitantes) }\end{array}$ & 6500 & PDC03 & 6 & $\begin{array}{l}\text { CAMINHÃO COM COLETOR } \\
\text { COMPACTADOR DELIXO }\end{array}$ \\
\hline $\begin{array}{c}\text { SERVIÇO } \\
\text { AUTOONOMO } \\
\text { MUNICIPALDE } \\
\text { ÁGUA EESGOTO DE } \\
\text { TIETÊ- - SAMAE }\end{array}$ & $\begin{array}{l}\text { SANEAMENTO } \\
\text { PÚBLICO }\end{array}$ & Concluído & $15 / 05 / 2002$ & $79.703,00$ & $50.297,00$ & $130.000,00$ & Município & Não reemb. & $\begin{array}{l}\text { Coleta e } \\
\text { Tratamento de } \\
\text { Esgotos } \\
\text { (habitantes) }\end{array}$ & 30000 & $\mathrm{PDC} 03$ & 12 & $\begin{array}{l}\text { TERMO DE REFERÊNCIA PARA } \\
\text { ELABORACCÃO DO PROJETO } \\
\text { EXECUTIVO DA ESTAÇÃO DE } \\
\text { TRATAMENTO }\end{array}$ \\
\hline $\begin{array}{l}\text { SERVIÇO } \\
\text { AUTÔNOMO DE } \\
\text { ÁGUA EESGOTO DE } \\
\text { SOROCABA -SAAE- }\end{array}$ & $\begin{array}{l}\text { PREFEITURA } \\
\text { MUNICIPAL }\end{array}$ & Concluído & 14/09/2000 & $74.391,61$ & $38.960,00$ & $113.351,61$ & Município & Reembolsável & $\begin{array}{l}\text { Estudos/Projetos } \\
\quad \text { (contratos) }\end{array}$ & 150000 & PDC01 & 12 & $\begin{array}{c}\text { ESTUDOS DE VIABILIDADE DE } \\
\text { EXPLORAČ̃̃O, } \\
\text { RECUPERAÇÃO/PRESERVAÇÃO DO RIO } \\
\text { PIRAJIBU }\end{array}$ \\
\hline $\begin{array}{l}\text { COMPANHIA DE } \\
\text { SANEAMENTO } \\
\text { BÁSICO DO ESTADO } \\
\text { DE SÃO PAULO - } \\
\text { SABESP }\end{array}$ & $\begin{array}{l}\text { SANEAMENTO } \\
\text { BÁSICO }\end{array}$ & Concluído & $03 / 12 / 1999$ & $105.000,00$ & $70.341,04$ & $175.341,04$ & Estado & Reembolsável & $\begin{array}{l}\text { Coleta e } \\
\text { Tratamento de } \\
\text { Esgotos } \\
\text { (habitantes) }\end{array}$ & 2500 & $\mathrm{PDCO}_{3}$ & 12 & $\begin{array}{l}\text { IMPLANTAÇÃO DE ESTAÇÃO DE } \\
\text { TRATAMENTO DE ESGOTOS DO } \\
\text { MUNICÍIIO DE QUADRA }\end{array}$ \\
\hline $\begin{array}{l}\text { SINDICATO DOS } \\
\text { PESCADORES } \\
\text { ARTESANAIS DO } \\
\text { ESTADO DESÃO }\end{array}$ & $\begin{array}{l}\text { ENTIDADE } \\
\text { SINDICAL }\end{array}$ & Em execução & & $33.328,00$ & 0 & $33.328,00$ & Sociedade Civil & Não reemb. & $\begin{array}{l}\text { Estudos/Projetos } \\
\quad \text { (contratos) }\end{array}$ & 150000 & PDC01 & 12 & \\
\hline
\end{tabular}




\begin{tabular}{|c|c|c|c|c|c|c|c|c|c|c|c|c|c|}
\hline Nome do interessado & $\begin{array}{l}\text { Atividade principal do } \\
\text { interessado }\end{array}$ & $\begin{array}{c}\text { Situacãa do } \\
\text { empreendimento }\end{array}$ & $\begin{array}{l}\text { Data de } \\
\text { conclusão }\end{array}$ & Valor aprovado & $\begin{array}{c}\text { Valor de } \\
\text { contrapartida }\end{array}$ & Valor total & $\begin{array}{l}\text { Segmento do } \\
\text { interessado }\end{array}$ & Modalidade & $\begin{array}{l}\text { Benefício: } \\
\text { indicador }\end{array}$ & $\begin{array}{l}\text { População } \\
\text { beneficiada }\end{array}$ & PDC: sigla & $\begin{array}{l}\text { Tempo de } \\
\text { execução } \\
\text { (meses) }\end{array}$ & Descrição \\
\hline $\begin{array}{l}\text { PREFEITURA } \\
\text { MUNICIPALDE } \\
\text { JUMIRIM }\end{array}$ & $\begin{array}{l}\text { PREFEITURA } \\
\text { MUNICIPAL }\end{array}$ & Cancelado & $10 / 09 / 2002$ & $38.660,24$ & $9.665,06$ & $48.325,30$ & Município & Não reemb. & $\begin{array}{l}\text { Coleta e } \\
\text { Tratamento de } \\
\text { Esgotos } \\
\text { (habitantes) }\end{array}$ & 200 & PDC01 & (mineses) & $\begin{array}{l}\text { PLANO DIRETOR DE } \\
\text { DESENVOLVIMENTO }\end{array}$ \\
\hline $\begin{array}{l}\text { PREFEITURA } \\
\text { MUNICIPALDE } \\
\text { VOTORANTIM }\end{array}$ & $\begin{array}{l}\text { PREFEITURA } \\
\text { MUNICIPAL }\end{array}$ & Concluído & $01 / 10 / 2003$ & $360.000,00$ & $155.000,00$ & $515.000,00$ & Município & Não reemb. & $\begin{array}{l}\text { Coleta e } \\
\text { Tratamento de } \\
\text { Esgotos } \\
\text { (habitantes) }\end{array}$ & 38000 & $\mathrm{PDC} 03$ & 12 & $\begin{array}{l}\text { REAPROVEIT. EST. TRAT. RESÍDUOS } \\
\text { DA VOTOCEL P/ TRAT. DE ESGOTOS } \\
\text { DOMÉSTICOS }\end{array}$ \\
\hline $\begin{array}{l}\text { SERVIÇO } \\
\text { AUTÔNOMO DE } \\
\text { ÁGUA E ESGOTO DE } \\
\text { CERQULHLO }\end{array}$ & $\begin{array}{l}\text { SERVICCO DE } \\
\text { SANEAMENTO } \\
\text { BÁSICO }\end{array}$ & Cancelado & $07 / 11 / 2003$ & $150.000,00$ & $263.500,00$ & $413.500,00$ & Munić́pio & Não reemb. & $\begin{array}{l}\text { Coleta e } \\
\text { Tratamento de } \\
\text { Esgotos } \\
\text { (habitantes) }\end{array}$ & 10000 & $\mathrm{PDCO} 3$ & 12 & $\begin{array}{l}\text { IMPLANTAÇ̃̃O DO SISTEMA DE } \\
\text { DESAGUE DE LODO DA ETE - VALOS DE } \\
\text { OXIDAÇÃO, DO BAIRRO CECAP }\end{array}$ \\
\hline $\begin{array}{l}\text { CONSÓRCIO DE } \\
\text { ESTUDOS, } \\
\text { RECUPERACCÃO E } \\
\text { DESENVOLVIMENTO } \\
\text { DA BACIA DOS RIOS } \\
\text { SOROCABA E MÉDIO } \\
\text { TIETÊ - CERISO }\end{array}$ & $\begin{array}{c}\text { CONSÓRCIO } \\
\text { INTERMUNICIPAL }\end{array}$ & Cancelado & 26/04/2005 & $110.000,00$ & 0 & $110.000,00$ & Sociedade Civil & Não reemb. & $\begin{array}{l}\text { Planej. e Gerenc. } \\
\text { dos Recs. Hídricos } \\
\text { (contratos) }\end{array}$ & 2000000 & PDC01 & 9 & $\begin{array}{l}\text { DIRETRIZES PARA PLANEJAMENTO } \\
\text { DO USO EOCUPACCÃO DO SOLO DA } \\
\text { ÁREA ENVOLTÓRIA DA REPRESA } \\
\text { ITUPARARANGA }\end{array}$ \\
\hline $\begin{array}{l}\text { PREFEITURA } \\
\text { MUNICIPALDE } \\
\text { CESÁRIO LANGE }\end{array}$ & $\begin{array}{l}\text { PÚBLICA/EXECUTIV } \\
\text { A }\end{array}$ & Cancelado & 07/01/2005 & $149.596,98$ & $576.601,96$ & $726.198,94$ & Município & Não reemb. & $\begin{array}{l}\text { Coleta e } \\
\text { Tratamento de } \\
\text { Esgotos } \\
\text { (habitantes) }\end{array}$ & 13000 & $\mathrm{PDC} 03$ & 12 & $\begin{array}{l}\text { SISTEMA DE AFASTAMENTO E } \\
\text { TRATAMENTO DE ESGOTOS } \\
\text { SANITÁRIOS }\end{array}$ \\
\hline $\begin{array}{l}\text { PREFEITURA } \\
\text { MUNICIPAL DE } \\
\text { CERQUILHO }\end{array}$ & $\begin{array}{l}\text { PREFEITURA } \\
\text { MUNICIPAL }\end{array}$ & Concluído & 24/06/2005 & $61.440,64$ & $15.360,15$ & $76.800,79$ & Município & Não reemb. & $\begin{array}{l}\text { Trat.e Disposição } \\
\text { de Lixo - Obras } \\
\text { (habitantes) }\end{array}$ & 30000 & $\mathrm{PDC}_{3}$ & 12 & $\begin{array}{l}\text { DISPOSIÇÃO FINAL DE RESÍDUOS } \\
\text { SÓLIDOS }\end{array}$ \\
\hline $\begin{array}{l}\text { UNESP - INSTITUTO } \\
\text { DE BIOCIÊNCIAS DE } \\
\text { BOTUCATU }\end{array}$ & $\begin{array}{l}\text { ENSINO SUPERIOR E } \\
\text { PESQUISA }\end{array}$ & Concluído & 22/09/2006 & $119.569,00$ & $29.892,25$ & $149.461,25$ & Estado & Não reemb. & $\begin{array}{l}\text { Educação } \\
\text { Ambiental } \\
\text { (contratos) }\end{array}$ & 50000 & PDC01 & 12 & $\begin{array}{c}\text { EDUCAÇÃO AMBIENTAL NA REGIÃO } \\
\text { DE BOTUCATU }\end{array}$ \\
\hline $\begin{array}{l}\text { COMPANHIA DE } \\
\text { SANEAMENTO } \\
\text { BÁSICO DO ESTADO } \\
\text { DE SÃO PAULO - } \\
\text { SABESP }\end{array}$ & $\begin{array}{l}\text { SANEAMENTO } \\
\text { BÁSICO }\end{array}$ & Concluído & 06/04/2005 & $44.657,49$ & $263.828,41$ & $308.485,90$ & Estado & Não reemb. & $\begin{array}{l}\text { Coleta e } \\
\text { Tratamento de } \\
\text { Esgotos } \\
\text { (habitantes) }\end{array}$ & 15000 & $\mathrm{PDC} 03$ & 12 & \\
\hline $\begin{array}{c}\text { SERVIÇO } \\
\text { AUTÔNOMO DE } \\
\text { ÁGUA EESGOTO DE } \\
\text { PORTO FELIZ (SAAE) }\end{array}$ & $\begin{array}{l}\text { PREFEITURA } \\
\text { MUNICIPAL }\end{array}$ & Cancelado & $11 / 09 / 2003$ & $110.800,00$ & $27.700,00$ & $138.500,00$ & Município & Não reemb. & Outros (contratos) & 42427 & PDC05 & 0 & $\begin{array}{l}\text { PROJETO SOS-A VECUIA; CONFORME } \\
\text { DELIBERACCÃ CBH-SMT-109/02, DE } \\
\text { 29/11/2002 EO TOMADOR FOI } \\
\text { SUBSTITUIDO }\end{array}$ \\
\hline $\begin{array}{l}\text { PREFEITURA } \\
\text { MUNICIPAL DE } \\
\text { LARANJAL } \\
\text { PAULISTA }\end{array}$ & $\begin{array}{l}\text { PREFEITURA } \\
\text { MUNICIPAL }\end{array}$ & Concluído & 08/10/2004 & $84.000,00$ & $21.000,00$ & $105.000,00$ & Município & Não reemb. & $\begin{array}{l}\text { Trat. e Disp. de } \\
\text { Lixo - } \\
\text { Veículos/Equips. } \\
\text { (contratos) }\end{array}$ & 22000 & $\mathrm{PDC} 03$ & 6 & $\begin{array}{l}\text { AQUISICC̃̃O DE EQUIPAMENTOS - } \\
\text { CAMINHÃO COM COLETOR } \\
\text { COMPACTADOR DELIXO }\end{array}$ \\
\hline $\begin{array}{l}\text { FUNDACCÃO PARA A } \\
\text { CONSERVACC̃̃OE E A } \\
\text { PRODUCÃO }\end{array}$ & $\begin{array}{l}\text { CONSERVAC̄̃̃O, } \\
\text { PRODUCAÕ E }\end{array}$ & & & & & & & & & & & & \\
\hline $\begin{array}{l}\text { PRODUÇÃO } \\
\text { FLORESTAL DO } \\
\text { ESTADO DE SÃO } \\
\text { PAULO - FF }\end{array}$ & $\begin{array}{l}\text { PRODUÇAŌ E } \\
\text { RECUPERAÇÃO } \\
\text { FLORESTAL }\end{array}$ & Cancelado & $26 / 01 / 2001$ & $151.447,00$ & $45.000,00$ & $196.447,00$ & Estado & Não reemb. & Outros (contratos) & 0 & PDC01 & 0 & A SER INFORMADO PELO AT \\
\hline $\begin{array}{l}\text { SECRETARIA DE } \\
\text { ESTADO DO MEIO } \\
\text { AMBIENTE- SMA }\end{array}$ & $\begin{array}{l}\text { LICENCIAMENTOE } \\
\text { FISCALIZAÇÃO } \\
\text { AMBIENTAL }\end{array}$ & Cancelado & 24/08/2001 & $150.000,00$ & 0 & $150.000,00$ & Estado & Não reemb. & Outros (contratos) & 0 & $\mathrm{PDC} 03$ & 0 & A SER INFORMADO PELO AT \\
\hline $\begin{array}{l}\text { DEPARTAMENTO DE } \\
\text { AGUAS E ENERGIA } \\
\text { ELETRICA - DAEE } \\
\text { (SÃO PAULO) } \\
\text { SECRETARIA DE }\end{array}$ & $\begin{array}{l}\text { AUTARQUIA } \\
\text { PÚBLICA } \\
\text { ESTADUAL }\end{array}$ & Cancelado & $01 / 03 / 2002$ & $200.000,00$ & $50.000,00$ & $250.000,00$ & Estado & Não reemb. & Outros (contratos) & 0 & PDC09 & 0 & \\
\hline $\begin{array}{l}\text { ESTADO DO MEIO } \\
\text { AMBIENTE- } \\
\text { INSTITUTO }\end{array}$ & $\begin{array}{l}\text { MEIO AMBIENTEE } \\
\text { PESQUISA }\end{array}$ & Cancelado & $30 / 01 / 2003$ & $41.356,02$ & $25.920,00$ & $67.276,02$ & Estado & Não reemb. & Outros (contratos) & 0 & PDC01 & 0 & A SER INFORMADO PELO AT \\
\hline
\end{tabular}




\begin{tabular}{|c|c|c|c|c|c|c|c|c|c|c|c|c|c|}
\hline Nome do interessado & $\begin{array}{l}\text { Atividade principal do } \\
\text { interessado }\end{array}$ & $\begin{array}{c}\text { Situação do } \\
\text { empreendimento }\end{array}$ & $\begin{array}{l}\text { Data de } \\
\text { conclusão }\end{array}$ & Valor aprovado & $\begin{array}{c}\text { Valor de } \\
\text { contrapartida }\end{array}$ & Valor total & $\begin{array}{l}\text { Segmento do } \\
\text { interessado }\end{array}$ & Modalidade & $\begin{array}{l}\text { Benefício: } \\
\text { indicador }\end{array}$ & $\begin{array}{l}\text { População } \\
\text { beneficiada }\end{array}$ & PDC: sigla & $\begin{array}{l}\text { Tempo de } \\
\text { execução } \\
\text { (meses) }\end{array}$ & Descrição \\
\hline $\begin{array}{l}\text { SECRETARIA DE } \\
\text { ESTADO DO MEIO } \\
\text { AMBIENTE - } \\
\text { INSTITUTO } \\
\text { GEOLOGICO }\end{array}$ & $\begin{array}{l}\text { ÓRGÃO DE } \\
\text { PESQUISA DO } \\
\text { GOVERNO DE SÃO } \\
\text { PAULO }\end{array}$ & Concluído & $15 / 02 / 2011$ & $115.000,00$ & $114.039,42$ & $229.039,42$ & Estado & Não reemb. & $\begin{array}{l}\text { Estudos/Projetos } \\
\quad \text { (contratos) }\end{array}$ & 2000000 & PDC01 & 24 & $\begin{array}{l}\text { SISTEMA DE INFORMAÇÕES } \\
\text { GEOREFERENCIADAS DA MINERAÇAO } \\
\text { NA BACIA HIDROGRÁFICA DO RIO } \\
\text { SOROCABA - RACIONA }\end{array}$ \\
\hline $\begin{array}{l}\text { SECRETARIA DE } \\
\text { ESTADO DO MEIO } \\
\text { AMBIENTE - } \\
\text { INSTITUTO } \\
\text { FLORESTAL }\end{array}$ & $\begin{array}{l}\text { MEIO AMBIENTEE } \\
\text { PESQUISA }\end{array}$ & Concluído & 08/03/2004 & $41.356,02$ & $25.920,00$ & $67.276,02$ & Estado & Não reemb. & $\begin{array}{l}\text { Estudos/Projetos } \\
\text { (contratos) }\end{array}$ & 1301000 & PDC01 & 6 & $\begin{array}{l}\text { - BENEFíCIOS: LEVANTAMENTO DAS } \\
\text { DIFERENTES CATEGORIAS DE } \\
\text { VEGETAÇÃO NATURALE TAMBÉM } \\
\text { REFLORESTAMENTO, }\end{array}$ \\
\hline $\begin{array}{l}\text { PREFEITURA } \\
\text { MUNICIPAL DE } \\
\text { BOTUCATU }\end{array}$ & $\begin{array}{l}\text { PREFEITURA } \\
\text { MUNICIPAL }\end{array}$ & Cancelado & 17/11/2003 & $200.000,00$ & $50.000,00$ & $250.000,00$ & Município & Não reemb. & $\begin{array}{l}\text { Galerias de Águas } \\
\text { Pluviais (metros } \\
\quad \text { lineares) }\end{array}$ & 15000 & PDC09 & 12 & $\begin{array}{l}\text { - CANCELADO CONFORME OFÍCIO CBH- } \\
\text { SMT No 287/2003 }\end{array}$ \\
\hline $\begin{array}{c}\text { SERVICOO } \\
\text { AUTÔNOMO DE } \\
\text { ÁGUA EESGOTO DE } \\
\text { ITU }\end{array}$ & $\begin{array}{l}\text { PREFEITURA } \\
\text { MUNICIPAL }\end{array}$ & Cancelado & 18/07/2005 & $111.543,00$ & $56.457,00$ & $168.000,00$ & Município & Não reemb. & $\begin{array}{l}\text { Educacãão } \\
\text { Ambiental } \\
\text { (contratos) }\end{array}$ & 122528 & PDC09 & 10 & $\begin{array}{l}\text { ATIVIDADES DE EDUCACC̃̃O } \\
\text { AMBIENTAL, DESASSOREAMWENTO E } \\
\text { REFORMA DO VIVEIRO DE MUDAS }\end{array}$ \\
\hline $\begin{array}{l}\text { PREFEITURA } \\
\text { MUNICIPALDE } \\
\text { PIEDADE } \\
\text { SERVIÇO }\end{array}$ & $\begin{array}{l}\text { PREFEITURA } \\
\text { MUNICIPAL }\end{array}$ & Concluído & $21 / 10 / 2009$ & $64.000,00$ & 0 & $64.000,00$ & Município & Não reemb. & $\begin{array}{l}\text { Planej. . Gerenc. } \\
\text { dos Recs. Hídricos } \\
\text { (contratos) }\end{array}$ & 50119 & PDC01 & 12 & \\
\hline $\begin{array}{l}\text { AUTÔNOMO } \\
\text { MUNICIPALDE } \\
\text { ÁGUA EESGOTO DE } \\
\text { TIETÊ-SAMAE }\end{array}$ & $\begin{array}{l}\text { SANEAMENTO } \\
\text { PÚBLICO }\end{array}$ & Cancelado & 20/05/2004 & $120.000,00$ & $30.000,00$ & $150.000,00$ & Município & Não reemb. & $\begin{array}{l}\text { Estudos/Projetos } \\
\quad \text { (contratos) }\end{array}$ & 34000 & PDC03 & 36 & \\
\hline $\begin{array}{l}\text { PREFEITURA } \\
\text { MUNICIPALDE } \\
\text { QUADRA }\end{array}$ & $\begin{array}{l}\text { PREFEITURA } \\
\text { MUNICIPAL }\end{array}$ & Concluído & 24/10/2006 & $120.000,00$ & $29.000,00$ & $149.000,00$ & Município & Não reemb. & $\begin{array}{l}\text { Estudos/Projetos } \\
\text { (contratos) }\end{array}$ & 2884 & PDC01 & 6 & $\begin{array}{l}\text { ELABORAÇÃO DO PLANO DIRETOR DO } \\
\text { MUNICIPIO DE QUADRA }\end{array}$ \\
\hline $\begin{array}{l}\text { PREFEITURA } \\
\text { MUNICIPALDE } \\
\text { PORTO FELLZ }\end{array}$ & $\begin{array}{l}\text { PREFEITURA } \\
\text { MUNICIPAL }\end{array}$ & Concluído & 24/05/2007 & $110.800,00$ & $27.700,00$ & $138.500,00$ & Município & Não reemb. & $\begin{array}{l}\text { Educação } \\
\text { Ambiental } \\
\text { (contratos) } \\
\text { Coletae }\end{array}$ & 44000 & PDC05 & 12 & PROJETO SOS-A VECUIA \\
\hline $\begin{array}{l}\text { PREFEITURA } \\
\text { MUNICIPALDE } \\
\text { JUMIRIM }\end{array}$ & $\begin{array}{l}\text { PREFEITURA } \\
\text { MUNICIPAL }\end{array}$ & Concluído & 08/06/2005 & $38.660,24$ & $33.188,76$ & $71.849,00$ & Município & Não reemb. & $\begin{array}{l}\text { Tratamento de } \\
\text { Esgotos } \\
\text { (habitantes) }\end{array}$ & 200 & PDC03 & 2 & $\begin{array}{l}\text { AMPLIACCÃO DA REDE DE ESGOTOS E } \\
\text { TRAVESSIA SUBTERRÂNEA }\end{array}$ \\
\hline $\begin{array}{l}\text { PREFEITURA } \\
\text { MUNCIPALDE } \\
\text { BOTUCATU }\end{array}$ & $\begin{array}{l}\text { PREFEITURA } \\
\text { MUNICIPAL }\end{array}$ & Concluído & $15 / 03 / 2005$ & $199.998,88$ & $76.691,48$ & $276.690,36$ & Município & Não reemb. & $\begin{array}{l}\text { Galerias de Águas } \\
\text { Pluviais (metros } \\
\text { lineares) }\end{array}$ & 2000 & PDC08 & 3 & $\begin{array}{l}\text { CONSTRUÇ̃̃̃O DE GALERIA DE ÁGUAS } \\
\text { PLUVIAIIN NO LOTEAMENTO } \\
\text { RESIDENCIAL SERRA NEGRA }\end{array}$ \\
\hline $\begin{array}{c}\text { SERVIÇO } \\
\text { AUTONNOMO DE } \\
\text { ÁGUA EEGOTO DE } \\
\text { CERQUILHO }\end{array}$ & $\begin{array}{l}\text { SERVIÇO DE } \\
\text { SANEAMENTO } \\
\text { BÁSICO }\end{array}$ & Concluído & 10/04/2007 & $150.000,00$ & $526.287,38$ & $676.287,38$ & Município & Não reemb. & $\begin{array}{l}\text { Coleta e } \\
\text { Tratamento de } \\
\text { Esgotos } \\
\text { (habitantes) }\end{array}$ & 29725 & PDC03 & 12 & $\begin{array}{l}\text { TRATAMENTO PRELIMINAR DE } \\
\text { ESGOTO DA ETE RIBERÃO DA } \\
\text { SERRA/CAPOAVA }\end{array}$ \\
\hline $\begin{array}{l}\text { FUNDACCÃO DE } \\
\text { ESTUDOS E } \\
\text { PESQUISAS } \\
\text { AGRÍCOLAS E } \\
\text { FLORESTAIS }\end{array}$ & $\begin{array}{c}\text { PESQUISA E } \\
\text { DESENVOLVIMENTO } \\
\text { EXPERIMENTAL EM } \\
\text { CIÊNCIAS FÍSICAS E } \\
\text { NATURAIS }\end{array}$ & Concluído & $24 / 10 / 2008$ & $148.400,00$ & $66.767,52$ & $215.167,52$ & Sociedade Civil & Não reemb. & $\begin{array}{l}\text { Estudos/Projetos } \\
\quad \text { (contratos) }\end{array}$ & 2000000 & PDC09 & 24 & $\begin{array}{c}\text { LEVANTAMENTO DE } \\
\text { CARACTERÍSTICAS DO ENTORNO, } \\
\text { MONITORAMENTO DE QUALIDADE DE } \\
\text { ÁGUA ECONCENTRAÇÃO DE COM }\end{array}$ \\
\hline $\begin{array}{l}\text { PREFEITURA } \\
\text { MUNICIPAL DE } \\
\text { BOFETE }\end{array}$ & $\begin{array}{l}\text { PREFEITURA } \\
\text { MUNICIPAL }\end{array}$ & Concluído & 10/08/2006 & $94.119,00$ & $22.900,20$ & $117.019,20$ & Município & Não reemb. & $\begin{array}{l}\text { Abastecimento de } \\
\text { Água (habitantes) }\end{array}$ & 350 & PDC04 & 3 & $\begin{array}{l}\text { ABASTECIMENTO DE ÁGUA POTÁ VEL } \\
\text { EM BAIRRO DISTABTE DA SEDE } \\
\text { MUNICIPAL }\end{array}$ \\
\hline
\end{tabular}




\begin{tabular}{|c|c|c|c|c|c|c|c|c|c|c|c|c|c|}
\hline Nome do interessado & $\begin{array}{l}\text { Atividade principal do } \\
\text { interessado }\end{array}$ & $\begin{array}{c}\text { Situação do } \\
\text { empreendimento }\end{array}$ & $\begin{array}{c}\text { Data de } \\
\text { conclusão }\end{array}$ & Valor aprovado & $\begin{array}{c}\text { Valor de } \\
\text { contrapartida }\end{array}$ & Valor total & $\begin{array}{l}\text { Segmento do } \\
\text { interessado }\end{array}$ & Modalidade & $\begin{array}{l}\text { Benefício: } \\
\text { indicador }\end{array}$ & $\begin{array}{c}\text { População } \\
\text { beneficiada }\end{array}$ & PDC: sigla & $\begin{array}{c}\text { Tempo de } \\
\text { execução } \\
\text { (meses) }\end{array}$ & Descrição \\
\hline $\begin{array}{l}\text { PREFEITURA } \\
\text { MUNICIPALDE } \\
\text { CONCHAS }\end{array}$ & $\begin{array}{l}\text { PREFEITURA } \\
\text { MUNICIPAL }\end{array}$ & Concluído & 22/02/2005 & $95.613,00$ & 22.992,00 & $118.605,00$ & Município & Não reemb. & $\begin{array}{c}\text { Poço Tubular } \\
\text { Profundo (m3/hora) }\end{array}$ & 1500 & PDC04 & 3 & $\begin{array}{l}\text { ABASTECIMENTO DE ÁGUA NO } \\
\text { DISTRITO DE JUQUIRATIBA. }\end{array}$ \\
\hline $\begin{array}{l}\text { PREFEITURA } \\
\text { MUNICIPAL DE } \\
\text { SALTO }\end{array}$ & $\begin{array}{l}\text { PREFEITURA } \\
\text { MUNICIPAL }\end{array}$ & Cancelado & $01 / 04 / 2004$ & $32.844,64$ & $8.211,16$ & $41.055,80$ & Município & Não reemb. & $\begin{array}{l}\text { Coleta e } \\
\text { Tratamento de } \\
\text { Esgotos } \\
\text { (habitantes) }\end{array}$ & 250 & $\mathrm{PDC}_{3}$ & 2 & $\begin{array}{l}\text { IMPLANTAÇÃO DE REDE DE ESGOTOS } \\
\text { NO BAIRRO BOM RETIRO II }\end{array}$ \\
\hline $\begin{array}{c}\text { SERVIÇO } \\
\text { AUTÔNOMO DE } \\
\text { ÁGUA EESGOTO DE } \\
\text { ITU }\end{array}$ & $\begin{array}{l}\text { PREFEITURA } \\
\text { MUNICIPAL }\end{array}$ & Concluído & $08 / 12 / 2005$ & $100.000,00$ & $26.817,29$ & $126.817,29$ & Município & Não reemb. & $\begin{array}{l}\text { Coleta e } \\
\text { Tratamento de } \\
\text { Esgotos } \\
\text { (habitantes) }\end{array}$ & 10000 & $\mathrm{PDC} 03$ & 2 & $\begin{array}{l}\text { SECAGEM DE LODO DA ETECANJICA } \\
\text { UTILIZANDO ESTUFAS AGRICOLAS }\end{array}$ \\
\hline $\begin{array}{l}\text { SERVICOO } \\
\text { AUTÔNOMO DE } \\
\text { ÁGUA EESGOTO DE } \\
\text { CERQUILHO }\end{array}$ & $\begin{array}{l}\text { SERVIÇO DE } \\
\text { SANEAMENTO } \\
\text { BÁSICO }\end{array}$ & Concluído & 30/06/2009 & $150.000,00$ & $161.192,02$ & $311.192,02$ & Munić́pio & Não reemb. & $\begin{array}{c}\text { Coletae } \\
\text { Tratamento de } \\
\text { Esgotos } \\
\text { (habitantes) }\end{array}$ & 30000 & $\mathrm{PDC} 03$ & 9 & $\begin{array}{l}\text { TRATAMENTO DE } 100 \% \text { DOS ESGOTOS } \\
\text { DA BACIA DO RIBEIRÃO DA SERRA }\end{array}$ \\
\hline $\begin{array}{c}\text { SERVICOO } \\
\text { AUTOONOMO DE } \\
\text { ÁGUA EESGOTO DE } \\
\text { SOROCABA-SAAE- }\end{array}$ & $\begin{array}{l}\text { PREFEITURA } \\
\text { MUNICIPAL }\end{array}$ & Concluído & $30 / 09 / 2008$ & $150.000,00$ & $158.935,30$ & $308.935,30$ & Município & Não reemb. & $\begin{array}{l}\text { Coletae } \\
\text { Tratamento de } \\
\text { Esgotos } \\
\text { (habitantes) }\end{array}$ & 537000 & $\mathrm{PDC}_{3}$ & 6 & $\begin{array}{l}\text { PROJETO EXECUTIVO DO EMISSÁRIO } \\
\text { DEESGOTOS S2 (MARGENS DO RIO } \\
\text { SOROCABA) }\end{array}$ \\
\hline $\begin{array}{l}\text { ASSOCIAÇÃO } \\
\text { ECOLÓGICA SÃO } \\
\text { FRANCISCO DE } \\
\text { ASSIS - AESFA }\end{array}$ & $\begin{array}{l}\text { CURSOS DE } \\
\text { EDUCAÇÃO } \\
\text { AMBIENTAL }\end{array}$ & Em execução & & $38.700,00$ & $10.010,52$ & $48.710,52$ & Sociedade Civil & Não reemb. & $\begin{array}{l}\text { Educacãão } \\
\text { Ambiental } \\
\text { (contratos) }\end{array}$ & 60000 & PDC12 & 22 & $\begin{array}{c}\text { PROGRAMA DE EDUCAÇ̃̃O } \\
\text { AMBIENTAL NOS ALTOS DO } \\
\text { PARANAPIACABA, VISANDO A } \\
\text { CONSCIENTIZAÇÃ̃O E IDENTIDADEDA }\end{array}$ \\
\hline $\begin{array}{l}\text { DEPARTAMENTO DE } \\
\text { AGUAS E ENERGIA } \\
\text { ELETRICA - DAEE } \\
\text { (SÃO PAULO) }\end{array}$ & $\begin{array}{l}\text { AUTARQUIA } \\
\text { PÚBLICA } \\
\text { ESTADUAL }\end{array}$ & Concluído & 14/10/2008 & $149.442,00$ & $188.490,00$ & $337.932,00$ & Estado & Não reemb. & $\begin{array}{l}\text { Estudos/Projetos } \\
\text { (contratos) }\end{array}$ & 12 & PDC01 & 12 & $\begin{array}{l}\text { MONITORAMENTO HIDROLÓGICO DA } \\
\text { BACIA HIDROGRÁFICA DO RIO } \\
\text { SOROCABA - } 1^{\mathrm{a}} \text { FASE }\end{array}$ \\
\hline $\begin{array}{l}\text { CETESB - } \\
\text { COMPANHIA } \\
\text { AMBIENTAL DO } \\
\text { ESTADO DE SÃO } \\
\text { PAULO }\end{array}$ & $\begin{array}{c}\text { AGÊNCIA } \\
\text { AMBIENTAL } \\
\text { ESTADUALDE } \\
\text { CONTROLLDA } \\
\text { POLUÇÃOE } \\
\text { TECNOLOGIA DE }\end{array}$ & Concluído & 26/07/2011 & $115.420,00$ & $156.163,80$ & $271.583,80$ & Estado & Não reemb. & $\begin{array}{l}\text { Estudos/Projetos } \\
\text { (contratos) }\end{array}$ & 1100000 & PDC01 & 20 & $\begin{array}{l}\text { DETALHAMENTO DAS INFORMAÇÕES } \\
\text { SOBRE A QUALDADE DAS ÁGUAS EM } \\
\text { SUB-BACIAS DE INTERESSE }\end{array}$ \\
\hline
\end{tabular}

